\author{
UNIVERSIDADE DE SÃO PAULO \\ ESCOLA DE ARTES, CIÊNCIAS E HUMANIDADES \\ PROGRAMA DE PÓS-GRADUAÇÃO EM SUSTENTABILIDADE \\ DIEGO PINHEIRO DE MENEZES
}

Regeneração florestal após desmatamento:

estudo da região de Santarém, Pará, Brasil 


\section{Regeneração florestal após desmatamento: estudo da região de Santarém, Pará, Brasil}

Dissertação apresentada à Escola de Artes, Ciências e Humanidades da Universidade de São Paulo para obtenção do título de Mestre em Ciências pelo Programa de Pós-Graduação em Sustentabilidade.

Versão corrigida contendo as alterações solicitadas pela comissão julgadora em quinze de março de 2017. A versão original encontra-se reservado na Biblioteca da $\mathrm{EACH} / \mathrm{USP}$ e na Biblioteca Digital de Teses e Dissertações da USP (BDTD), de acordo com a Resolução CoPGr 6018, de 13 de outubro de 2011.

Área de Concentração:

Ciência e Tecnologia Ambiental.

Orientador:

Prof. Dr. Waldir Mantovani 
Autorizo a reprodução e divulgação total ou parcial deste trabalho, por qualquer meio convencional ou eletrônico, para fins de estudo e pesquisa, desde que citada a fonte.

CATALOGAÇÃO-NA-PUBLICAÇÃO

(Universidade de São Paulo. Escola de Artes, Ciências e Humanidades. Biblioteca)

Menezes, Diego Pinheiro de

Regeneração florestal após desmatamento : estudo da região de Santarém, Pará, Brasil / Diego Pinheiro de Menezes ; orientador, Waldir Mantovani. - São Paulo, 2017 193 p. : il

Dissertação (Mestrado em Ciências) - Programa de PósGraduação em Sustentabilidade, Escola de Artes, Ciências e Humanidades, Universidade de São Paulo Versão corrigida

1. Florestas - Santarém (PA). 2. Florestas - Regeneração Santarém (PA). 3. Florestas - Monitoramento - Santarém (PA). 4. Desmatamento - Santarém (PA). 5. Sensoriamento remoto. I. Mantovani, Waldir, orient. II. Título

CDD 22.ed. -577.34098115 
Nome: MENEZES, Diego Pinheiro de

Título: Regeneração florestal após desmatamento: estudo da região de Santarém, Pará, Brasil

Dissertação apresentada à Escola de Artes, Ciências e Humanidades da Universidade de São Paulo para obtenção do título de Mestre em Ciências pelo Programa de Pós-Graduação em Sustentabilidade.

Área de Concentração:

Ciência e Tecnologia Ambiental.

Aprovado em: $15 / 03$ / 2017.

\section{Banca examinadora}

Prof. Dr. Luís Américo Conti

Universidade de São Paulo, Escola de Artes Ciências e Humanidades

Profa. Dra. Mariana Abrantes Gianotti

Universidade de São Paulo, Escolha Politécnica

Prof. Dr. Mateus Batistella

Empresa Brasileira de Pesquisa Agropecuária 


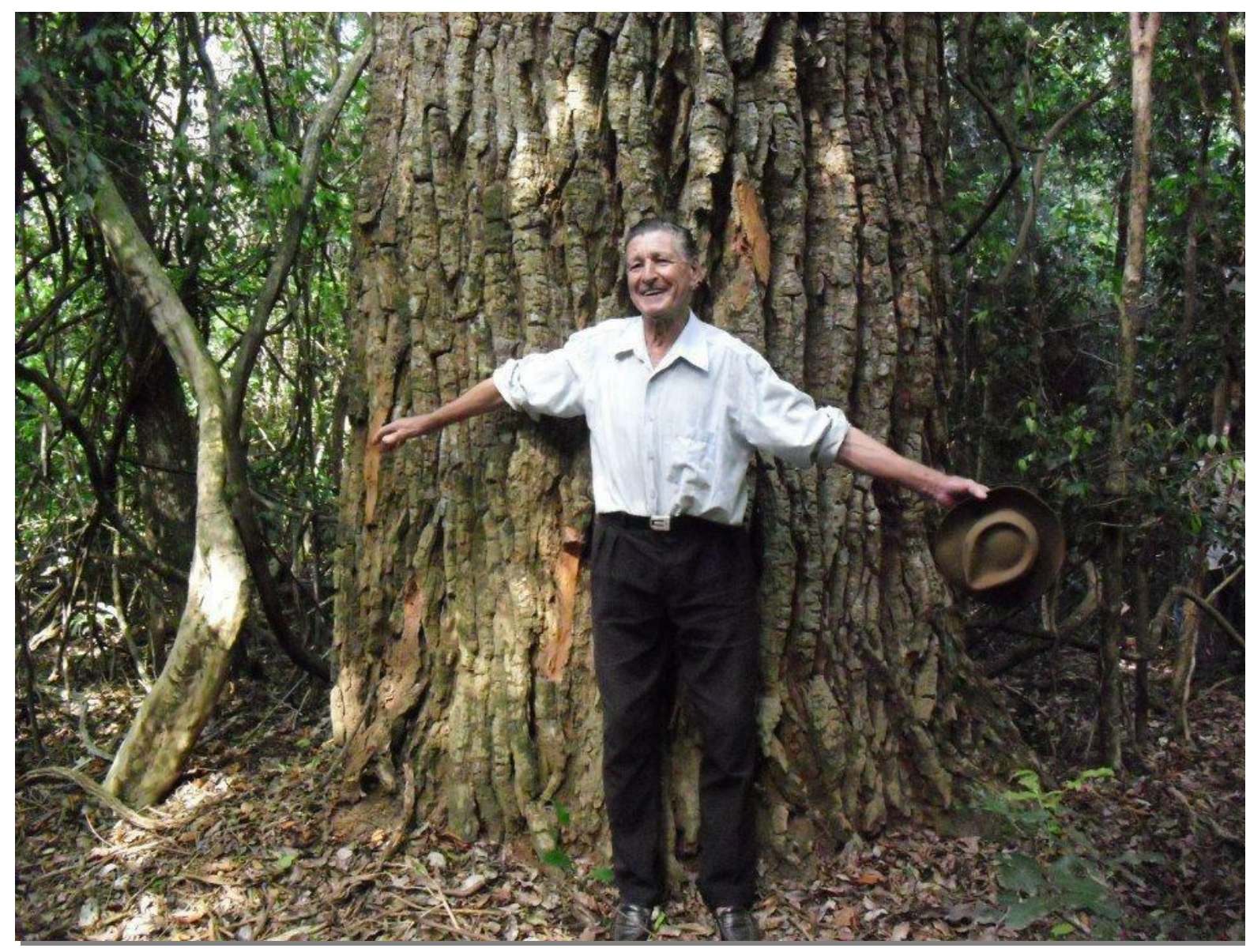

Dedico este trabalho ao meu avô Daniel Pinheiro, pioneiro em Moreira Sales (região do noroeste paranaense) na década de 1950. Ele, tão grande e querido quanto a perobeira no sítio dele. 


\section{AGRADECIMENTOS}

Ao Professor Waldir Mantovani pela orientação, sugestões valiosas e, principalmente, acreditar na viabilidade deste projeto.

Ao Professor Homero Fonseca Filho pela presença constante e contribuição à orientação desde o início deste trabalho.

Ao Laboratório de Computação Geoespacial (LACGEO) da EACH-USP, pela disponibilização de espaço físico e uso do aplicativo ENVI 5.0.

Aos funcionários da secretaria de pós-graduação da EACH-USP pela permanente disponibilidade.

Ao Projeto Paisagens Sustentáveis (EMBRAPA e Serviço Florestal Americano, pela participação no workshop realizado em maio de 2016. Mateus e Michael, obrigado.

A Trimble Inc. pelo fornecimento da licença do aplicativo ECOGNITION 9.2.

Ao Programa Xingu do Instituto Socioambiental (ISA), que permitiu conciliar as atividades profissionais e acadêmicas. Ao Laboratório de Geoprocessamento do ISA pela disponibilização do uso dos aplicativos ARCGIS 10.4 e do ENVI 5.0.

A The Nature Conservancy (TNC) no Brasil pela disponibilização de fotografias do sobrevoo realizado na região de Santarém em maio de 2012.

Ao Instituto de Estudos Avançados da USP e ao Instituto Democracia e Sustentabilidade pela realização dos encontros "Diálogos sobre a Amazônia na Contemporaneidade", entre 2015 e 2016

Meu agradecimento especial aos meus pais, Gerivaldo e Sidnéia, à minha noiva Ana Paula, e a minha irmã Jacqueline. Obrigado por terem proporcionado apoio e condições para chegar ao fim de mais esta etapa.

Aos amigos que, direta ou indiretamente, ajudaram com tempo e troca de ideias ao longo deste trabalho. 
...existiu primeiro uma terra propícia, existiu depois uma árvore secular feita de anos sossegados, e existiu finalmente uma prancha nodosa e dura trabalhada pelas mãos de um artesão dia após dia.

(NASSAR, 1989, p.56)

Que importa a paisagem, a Glória, a baía, a linha do horizonte? - O que vejo é o beco.

(BANDEIRA, Poema do beco, 1982, p.67) 


\section{RESUMO}

MENEZES, D. P. Regeneração florestal após desmatamento: estudo da região de Santarém, Pará, Brasil. 193 p. 2017. Dissertação (Mestrado em Ciências). Escola de Artes, Ciências e Humanidades, Universidade de São Paulo, São Paulo, 2017. Versão corrigida.

A superfície da terra foi modificada nos últimos 50 anos mais do que em qualquer outro período da História, mais intensa e rápida nos trópicos pela expansão das frentes de ocupação humana sobre floresta madura. A Amazônia brasileira, caracterizada pela alternância de ciclos econômicos extrativistas, exemplifica esse processo. Entre o abandono de áreas degradadas e a abertura de novas frentes de ocupação, ocorre a regeneração florestal. A floresta secundária tem uma reconhecida importância para o restabelecimento das funções dos ecossistemas e dos estoques de nutrientes perdidos da floresta madura, mas ignorados por muitos anos de taxas oficiais de desmatamento na Amazônia brasileira. Este estudo apresenta uma abordagem utilizando Análise de Imagens Baseada em Objetos Geográficos (GEOBIA) para classificar os estágios de sucessão secundária numa área com cerca de $11.124 \mathrm{~km}^{2}$ na região de Santarém (Pará, Brasil). Dentre os resultados, foram produzidas 19 diferentes classificações cobrindo o período 1984 a 2016, que permitiu identificar a redução da floresta madura e da floresta secundária devido à expansão da fronteira agrícola. Outro resultado relevante foi a modelagem de uma árvore de decisão aplicável às imagens de refletância de superfície coletadas pelos satélites LANDSAT, processando esses atributos de classificação em um aplicativo de mineração de dados.

Palavras-chave: Desmatamento. Regeneração florestal. Floresta secundária. Análise de imagens baseada em objetos geográficos. 


\begin{abstract}
MENEZES, D. P. Regrowth forest after deforestation: study on Santarém region, Para, Brazil. 193 p. 2017. Dissertation (Master of Science). School of Arts, Sciences and Humanities, University of São Paulo, São Paulo, 2017. Corrected version.

The earth surface was modified in the last 50 years more than in any other period of the History, more intense and fast in the tropics by the expansion of human occupation frontiers on the mature forest. The Brazilian Amazon, characterized by alternating extractive economic cycles, exemplifies this process. Between the degraded areas abandonment and the new occupation fronts, forest regeneration takes place. The secondary forest has a recognized importance for the restoration of ecosystem functions and the nutrient stocks lost from the mature forest but ignored for many years of official deforestation rates in the Brazilian Amazon. In this study, an approach using Geographic Object-Based Imaging Analysis (GEOBIA) is presented to classify the stages of secondary succession in an area with near $11,124 \mathrm{~km}^{2}$ on Santarém region (Pará State, Brazil). Among the results, 19 different classifications were produced covering the period 1984 to 2016 , which allowed identify the reduction of mature forest and secondary forest due to agricultural frontier expansion. Another relevant result was the modeling of a decision tree applicable to surface reflectance images collected by the LANDSAT satellites, processing these classifications attributes in a data mining software.
\end{abstract}

Key-words: Deforestation. Forest regrowth. Secondary forest. Geographic objectbased image analysis. 


\section{LISTA DE FIGURAS}

Figura 1 - Localização e extensão da área de estudo ...........................................27

Figura 2 - Fragmento de "Mapa Geographica del rio Maranõn o Amazonas". ..........32

Figura 3 - Diagrama representativo de roça Mundurucu. ..........................................35

Figura 4 - Aldeia e roça mundurucu na Terra Indígena "Sai-Cinza"...........................36

Figura 5 - "Carte du Cours du Maragnon ou de la Grande Riviere des Amazones" ..39

Figura 6 - A borracha e o café nas exportações brasileiras: 1850 a 1920 ................41

Figura 7 - Esquema de um seringal amazônico, por volta de 1900...........................43

Figura 8 - Fordlândia: Plantio de seringueiras em colina desmatada .........................45

Figura 9 - Área de cultivo de seringueiras em Belterra pela Ford Motor Co..............46

Figura 10 - Trecho não pavimentado da BR-163, em Belterra ..................................50

Figura 11 - Modelo dos padrões de ocupação espinha de peixe e dendrítico ..........51

Figura 12 - Desmatamento nos Estados da Amazônia Legal.....................................53

Figura 13 - Desmatamento na área de estudo conforme o município ........................57

Figura 14 - Desmatamento, preço da terra e crédito rural no Estado do Pará ...........58

Figura 15 - Crédito rural e desmatamento em Belterra e Santarém ............................60

Figura 16 - Crédito rural e desmatamento em Prainha e Uruará................................61

Figura 17 - Evolução das classes de mapeamento no TERRACLASS ......................73

Figura 18 - Fluxograma aplicado à classificação de floresta secundária ..................77

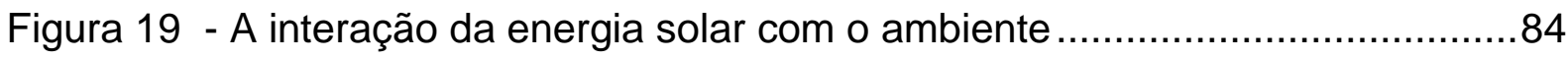

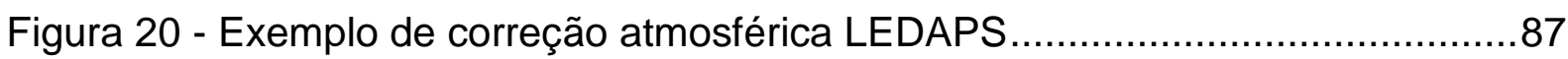

Figura 21 - Representação de uma árvore de decisão .....................................100

Figura 22 - Árvore de decisão gráfica para a classificação de 2015 ......................101

Figura 23 - Elementos reconhecíveis na classificação de imagem ........................106

Figura 24 - Transição entre pastagem, SS2 (fundo) e SS3 (lateral) ........................108

Figura 25 - Área desmatada em 2005 e em regeneração (SS1) ...........................108

Figura 26 - Transição entre regeneração (SS1) e floresta madura (SS3) ...............109

Figura 27 - Transição entre dois estágios de regeneração (SS1 e SS2) ................109

Figura 28 - Floresta de inundação e macrófitas (aninga - Montichardia Araceae) na várzea do rio Amazonas.............................................................................110

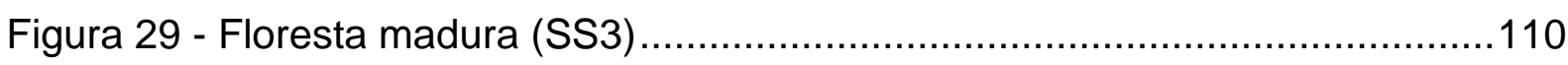

Figura 30 - Savana parque (cerrado) próximo a Alter do Chão...............................111

Figura 31 - Área destinada a agricultura anual em Belterra ..................................111 
Figura 32 - Tamanho das regras de decisão de cada classificação ........................116

Figura 33 - Acerto, erro médio e Kappa das classificações .................................116

Figura 34 - Acurácia detalhada da classificação de 2015 ...................................119

Figura 35 - Matriz de confusão da classificação de 2015 ...................................120

Figura 36 - Precipitação e evaporação (piche) média mensal - 1984 a 2016 .........123

Figura 37 - Distribuição dos valores limiares usando SAVI ...................................124

Figura 38 - Distribuição dos valores limiares usando NDWI .................................125

Figura 39 - Correlação dos valores medianos dos atributos analisados .................127

Figura 40 - Evolução das classes de sucessão secundária (dados brutos) .............131

Figura 41 - Evolução das classes de cobertura vegetal e uso da terra ...................132

Figura 42 - Exemplo de resultados da classificação dos períodos analisados........134

Figura 43 - Trajetórias de alteração da paisagem .............................................135 


\section{LISTA DE MAPAS}

Mapa 1 - Vegetação da Área de Estudo …………............................................

Mapa 2 - Uso e Cobertura da terra - TERRACLASS ...........................................74

Mapa 3 - Localização dos pontos de verificação ...............................................112

Mapa 4 - Estágios de Sucessão Florestal em 1986 ........................................137

Mapa 5 - Estágios de Sucessão Florestal em 1995 ...........................................138

Mapa 6 - Estágios de Sucessão Florestal em 2006 ..........................................139

Mapa 7 - Estágios de Sucessão Florestal em 2012 .........................................140

Mapa 8 - Estágios de Sucessão Florestal em 2015 .........................................141

Mapa 9 - Estágios de Sucessão Florestal em 2016 ..........................................142 


\section{LISTA DE TABELAS}

Tabela 1 - Computo de área total dos municípios onde está a área de estudo ........26

Tabela 2 - Computo das fitofisionomias na área de estudo .29

Tabela 3 - Fases de evolução de políticas públicas e iniciativas de cadeias de fornecimento para reduzir o desmatamento na Amazônia: 2000 a 2013. .55

Tabela 4 - Desmatamento na área de estudo conforme o município .56

Tabela 5 - Estágios de sucessão secundária na Amazônia 65

Tabela 6 - Estágio de sucessão e licenciamento no Estado do Pará. 69

Tabela 7 - Contribuição ao desmatamento na Amazônia por década .70

Tabela 8 - Uso e cobertura da terra na área de estudo .72

Tabela 9 - Resumo das características espectrais das câmeras dos satélites LANDSAT 5 (TM e LANDSAT 7 (ETM+) .80

Tabela 10 - Resumo das características espectrais do satélite IRS-P6 (LISS3) .81

Tabela 11 - Resumo das características espectrais da câmera do satélite LANDSAT 8 (OLI)

Tabela 12 - Cenas orbitais selecionadas para análise .82

Tabela 13 - Parâmetros para correção atmosférica da imagem IRS-P6 .88

Tabela 14 - Quantidade de segmentos criados e segmentados amostrados para cada período de classificação .97

Tabela 15 - Valores limiares usados na construção da árvore de decisão 99

Tabela 16 - Comparação de quantidade de amostras usando o SIMPLECART .....113

Tabela 17 - Comparação de classificadores no WEKA 114

Tabela 18 - Resumo das árvores de decisão de cada classificação 115

Tabela 19 - Acurácia detalhada da classificação de 2015 118

Tabela 20 - Matriz de confusão da classificação de 2015 120

Tabela 21 - Dados da estação meteorológica de Belterra 123

Tabela 22 - Correlação dos valores medianos dos atributos analisados 126

Tabela 23 - Dados brutos obtidos da classificação de cada período analisado 130

Tabela 24 - Ocorrência de floresta secundária para cada período analisado 133

Tabela 25 - Cobertura florestal para cada período analisado conforme o estágio de sucessão 134 


\section{LISTA DE ABREVIATURAS}

AC - Antes de Cristo

AD - Anno Domini

AP - Antes do Presente

BIL - Band interleaved by line

BIP - Band interleaved by pixel

BSQ - Band sequential

CAR - Cadastro Ambiental Rural

CART - Classification and Regression Tree

DEM - Digital Elevation Model

DETER - Detecção de Desmatamentos em Tempo Real

DOS - Dark-object subtraction

ENVI - Environment for Visualizing Images

ERTS - Earth Resources Technology Satellite

ETM+ - Enhanced Thematic Mapper Plus

FLAASH - Fast Line-of-sight Atmospheric Analysis of Spectral Hypercubes

FLONA - Floresta Nacional

GCP - Ground Control Points

GEOBIA - Geographic Object-Based Image Analysis

GEOTIFF - Geographic Tagged Image File Format

GLCM - Gray-Level Co-occurrence Matrix

GLS - Global Land Survey

IDL - Interactive Data Language

IRS - Indian Resource Sat

LANDSAT - Land Surveillance Satellite

LDCM - Landsat Data Continuity Mission

LEDAPS - Landsat Ecosystem Disturbance Adaptive Processing System

LIDAR - Light detection and ranging

LISS - Medium Resolution Linear Imaging Self-Scanner 
LT1 - Level One Terrain Correction product

LPGS - Level-1 Product Generation System

MODIS - Moderate Resolution Imaging Spectroradiometer

MODTRAN - Moderate Resolution Transmittance

MSS - Multispectral Scanner

NBR - Normalized Burn Ratio

NDFI - Normalized Difference Fraction Index

NDII - Normalized Difference Infrared Index

NDMI - Normalized Difference Moisture Index

NDVI - Normalized Difference Vegetation Index

NDWI - Normalized Difference Water Index

OLI - Operational Land Imager

PA - Projeto de Assentamento

RESEX - Reserva Extrativista

SAVI - Soil-adjusted Vegetation Index

6S - Second Simulation of a Satellite Signal in the Solar Spectrum

SIG - Sistema de Informações Geográficas

SS - Sucessão secundária

TAC - Termo de Ajuste de Conduta

TI - Terra Indígena

TM - Thematic Mapper

UC - Unidade de Conservação

UHE - Usina ou Central hidrelétrica

UTM - Universal Transversa de Mercator

WEKA - Waikato Environment for Knowledge Analysis

WGS - World Geodetic System

ZCIT - Zona de Convergência Intertropical

ZEE - Zoneamento Ecológico-Econômico 


\section{LISTA DE SIGLAS}

ABNT - Associação Brasileira de Normas Técnicas

ABIOVE - Associação Brasileira das Indústrias de Óleo Vegetal

ANEC - Associação Nacional dos Exportadores de Cereais

BACEN - Banco Central do Brasil

CONAVEG - Comissão Nacional para Recuperação da Vegetação Nativa

EMBRAPA - Empresa Brasileira de Pesquisa Agropecuária

FGV - Fundação Getúlio Vargas

IBGE - Instituto Brasileiro de Geografia e Estatística

IBRE - Instituto Brasileiro de Economia

INPE - Instituto Nacional de Pesquisas Espaciais

INPE-CRA - Centro Regional da Amazônia do INPE

IMAZON - Instituto do Homem e Meio Ambiente da Amazônia

ISRO - Indian Space Research Organization

MPF - Ministério Público Federal

MMA - Ministério do Meio Ambiente

NASA - National Aeronautics and Space Administration

PPCDAM - Plano de Prevenção e Controle do Desmatamento na Amazônia Legal

PRODES - Programa de Monitoramento de Desmatamento da Floresta Amazônica por Satélite

PROVEG - Política Nacional de Recuperação da Vegetação Nativa

SEMAS - Secretaria de Estado de Meio Ambiente e Sustentabilidade do Pará

SPVEA - Superintendência do Plano de Valorização Econômica da Amazônia

SUDAM - Superintendência de Desenvolvimento da Amazônia

USGS - United States Geological Survey 


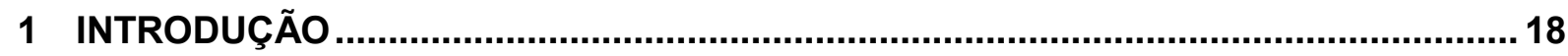

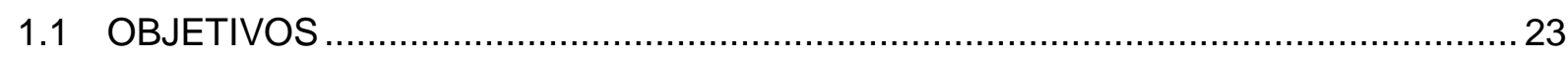

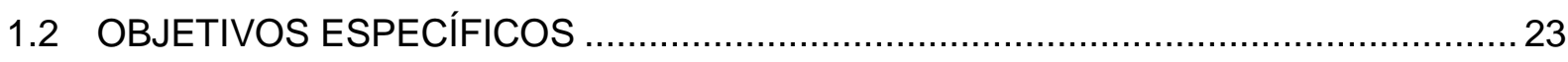

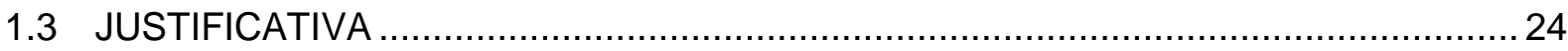

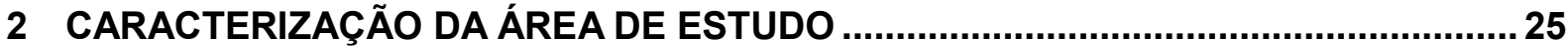

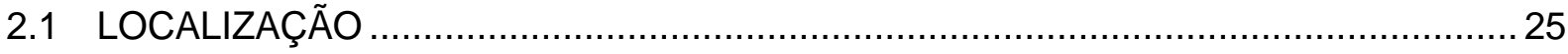

2.2 CARACTERIZAÇÃO FÍSICA DA ÁREA DE ESTUDO …..................................... 28

3 A EVOLUÇÃO dO USO E DA RELAÇÃO SOCIAL COM A TERRA NA REGIÃO DE SANTARÉM. 31

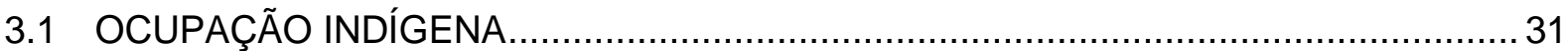

3.2 PERÍODO COLONIAL: DA FUNDAÇÃO DA VILA DE SANTARÉM ATÉ A CABANAGEM 37

3.3 A ECONOMIA DA BORRACHA: BASES DA ESTRUTURA ECONÔMICA ATUAL ...... 39

3.4 DINÂMICA RECENTE DO USO E COBERTURA DA TERRA ................................. 47

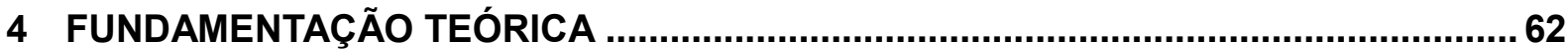

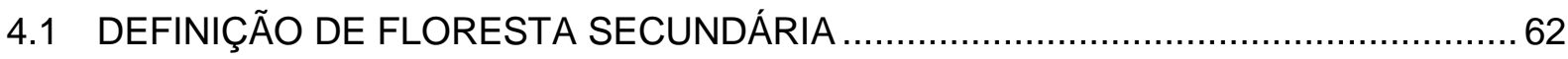

4.2 LEGISLAÇÃO PERTINENTE AO CORTE E CONSERVAÇÃO DE FLORESTA

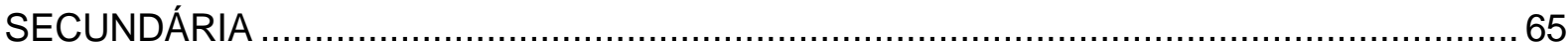

4.3 A CONTRIBUIÇÃO DOS ESTUDOS DE MUDANÇA NO USO DA TERRA AO

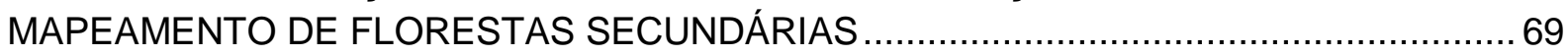

5 MÉTODO, MATERIAIS E PROCEDIMENTOS ........................................................... 75

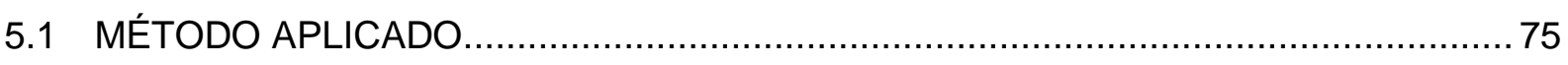

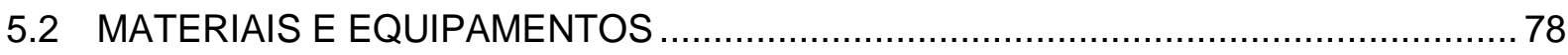

5.2.1 Recursos de informática (Hardware e Software)................................................. 78

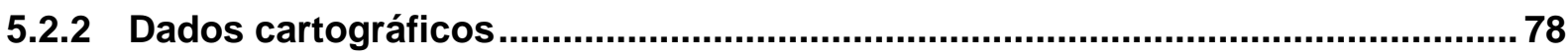

5.2.3 Dados orbitais e obtidos por sensoriamento remoto ......................................... 78

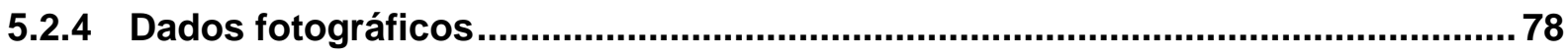

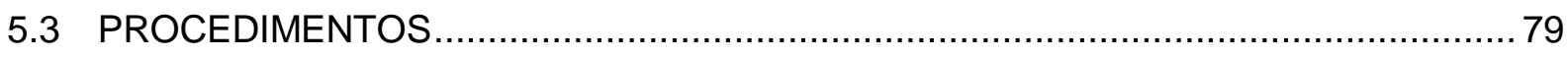

5.3.1 Características dos sistemas sensores utilizados................................................ 79

5.3.1.1 LANDSAT 5 e LANDSAT 7 (1984 a 2011) ..................................................... 79

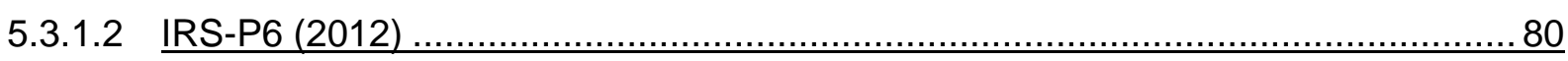




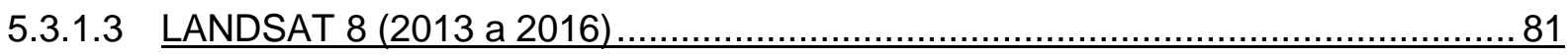

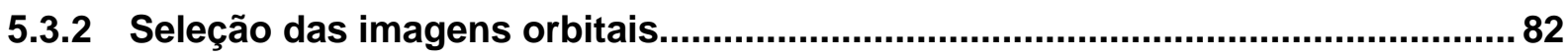

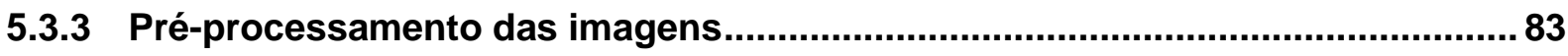

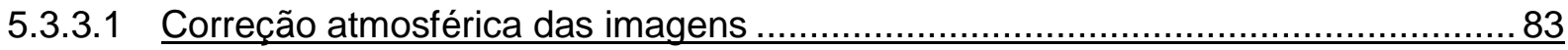

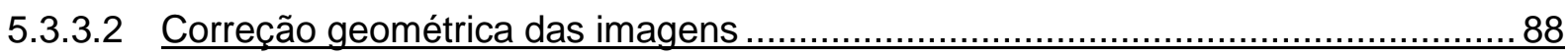

5.3.3.3 Operações de ajuste espectral, radiométrico e geométrico nas imagens. ............89

5.3.4 Segmentação .............................................................................................. 91

5.3.4.1 Atributos espectrais e de textura incorporados à segmentação ..........................92

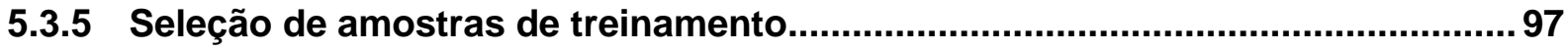

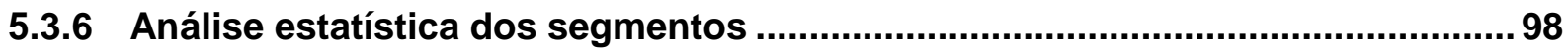

5.3.7 Construção das árvores de decisão .............................................................. 100

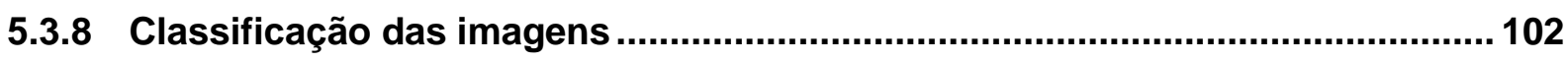

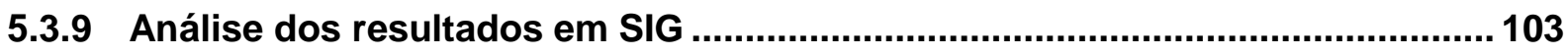

6 RESULTADOS E DISCUSSÃO........................................................................... 104

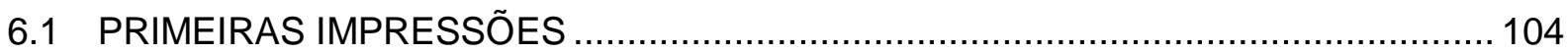

6.2 RECONHECIMENTOS DE ELEMENTOS EM IMAGENS DE SATÉLITE E

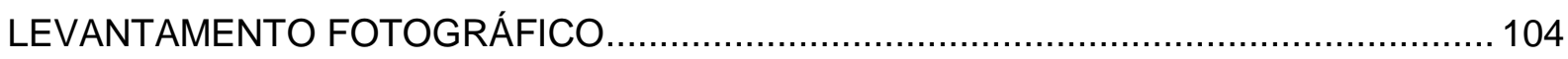

6.3 AVALIAÇÃO DA PERFORMANCE DA CLASSIFICAÇÃO …................................ 113

6.4 ANÁLISE DOS RESULTADOS DA CLASSIFICAÇÃO ...................................... 129

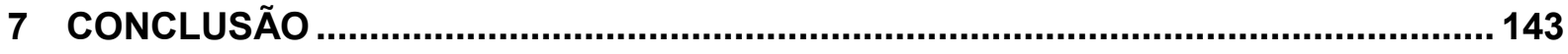

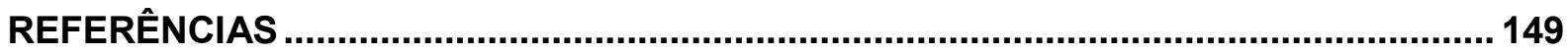

APÊNDICE 1. ÁRVORES DE DECISÃO CRIADAS NO WEKA PARA AS CLASSIFICAÇÕES

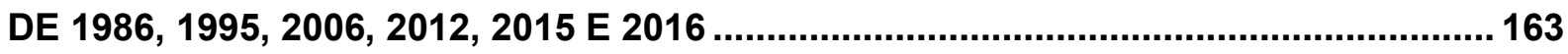

APÊNDICE 2. SUMÁRIO DOS RESULTADOS DAS CLASSIFICAÇÕES REALIZADAS NO

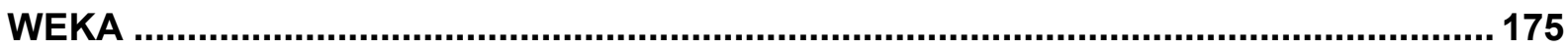




\section{INTRODUÇÃO}

Nos últimos 50 anos os seres humanos mudaram os ecossistemas mais rapidamente e extensivamente do que em qualquer período comparável da História, resultando em uma perda substancial e amplamente irreversível na diversidade da vida na Terra (MILLENIUM ECOSYSTEM ASSESTMENT, 2005). Como causa básica essencial deste processo, para Williams (2011, p.396), a Segunda Guerra Mundial irradiou mudanças políticas, econômicas, tecnológicas e demográficas para todos os cantos do mundo, mas para o mundo tropical significou principalmente o surgimento da noção de Terceiro Mundo e a alteração e destruição das paisagens dominantes.

As mudanças no uso da terra foram mais rápidas nos trópicos, onde o desequilíbrio entre desmatamento e a regeneração florestal possui grandes consequências para o ciclo de carbono global (HANSEN et al., 2013) e levaram a alterações igualmente significativas na bacia Amazônica (NOBRE et al., 2016). A porção brasileira da bacia amazônica, historicamente caracterizada por breves ciclos econômicos, tornou-se uma nova fronteira de ocupação por meio de novos projetos de exploração florestal e mineral, obras de infraestrutura e projetos de colonização, que levaram ao surgimento e à expansão de áreas urbanas e ao desmatamento.

Santarém é uma das regiões da Amazônia brasileira que exemplifica este processo. Fundada no século XVII sobre um aldeamento indígena às margens da confluência entre os rios Amazonas e Tapajós, este núcleo abrigou uma missão jesuíta e um forte militar, permitindo a sua proteção frente a invasores de outras nacionalidades, a destribalização dos indígenas e a ocupação do baixo Amazonas e do vale do Tapajós.

Nos dois séculos seguintes, a economia da região de Santarém se baseou no extrativismo do cacau e da borracha. As adversidades do meio ambiente, as más técnicas de manejo da terra, o pouco capital para investir e a escassez de mão de obra, agravada pelo florescimento da Cabanagem entre 1820 e 1850 (CLEARY, 1998) atrasaram o desenvolvimento da agricultura e da pecuária que emergem na segunda metade do século XX, ocupando as terras recentemente desmatadas e cobertas por florestas secundárias em diferentes estágios de sucessão. 
O primeiro ciclo da borracha permitiu o acúmulo de renda necessário para a formação de uma elite econômica e política em toda a Amazônia e, também, as bases para uma futura expansão do capital na região, através da dispersão de seringalistas e seringueiros para as mais remotas localidades, algumas com certo isolamento até o presente.

Este primeiro ciclo da borracha, vinculado ao mercado europeu, acabou no início do século XX como consequência da prática de cartel favorável ao látex produzido no sudeste asiático a um custo menor que o amazônico. Um segundo ciclo viria a ocorrer entre 1940 e 1945 para o suprimento de látex ao mercado americano, durante a Segunda Guerra Mundial, com o recrutamento de soldados da borracha da região Nordeste para a Amazônia (SANTOS, 1980; WEINSTEIN, 1993).

Os anos seguintes foram de nova marginalização econômica, que viria a ser alterada a partir da década de 1970 por ações estatais de incentivo à ocupação da Amazônia através da implantação de estradas transversais e radiais, ligando a região às demais regiões do Brasil, com a construção das primeiras usinas hidrelétricas (como a UHE Curuá-Una, em Santarém), o incentivo a grandes projetos de exploração florestal e mineral por empresas estatais e privadas e a colonização promovida por agentes privados (cooperativas, por exemplo) e pelo Estado, através de projetos de assentamentos rurais implantados pelo INCRA.

Eram as bases para uma nova fronteira de ocupação e expansão do capital que, sem dúvida, trouxe desenvolvimento econômico à região, mas trouxe, também, conflitos sociais e a perda de $623.705 \mathrm{~km}^{2}$ de florestas de acordo com os dados do PRODES (INPE, 2016), convertidas em áreas urbanas, pastagens, áreas agrícolas e florestas secundárias.

Após o recorde de 27.772 km² de floresta desmatada na Amazônia em 2004 segundo o PRODES (INPE, 2016), o governo brasileiro adotou a meta de reduzir em $80 \%$ a taxa de desmatamento na floresta amazônica até 2020 , através da política de comando e controle, o PPCDAM, a criação de novas unidades de conservação e terras indígenas e o estímulo tímido a alternativas econômicas. Esta meta, associada aos compromissos setoriais da cadeia da carne e da soja (GIBBS et al., 2015; ARIMA et al., 2014; VESBURG et al., 2012) levaram ao êxito no cumprimento da meta e à menor taxa de desmatamento já registrada, em 2012, com $4.571 \mathrm{~km}^{2}$. 
O êxito do PPCDAM na queda substancial das taxas de desmatamento na Amazônia Brasileira levou à articulação da Frente Parlamentar da Agropecuária (conhecida como bancada ruralista), que culminou com a criação do Novo Código Florestal, aprovado em 2012, em substituição ao Código Florestal de 1965.

O Código Florestal de 1965 foi transformado durante a década de 1990 em uma lei ambiental de fato, através de uma série de decretos presidenciais. A revisão desta peça central de regulação do uso e do manejo da terra em propriedades privadas no Brasil poderá ter consequências globais (SOARES-FILHO et al., 2014).

Uma das conquistas do Código Florestal de 1965 foi reservar a formação de florestas nas propriedades privadas, através do instrumento da Reserva Legal, que variava entre $50 \%$ e $80 \%$ nas propriedades localizadas na Amazônia. Em contraste, a lei florestal de 2012 anistiou quem desmatou até 2008 em posses e propriedades privadas com até quatro módulos fiscais ${ }^{1}$, exigindo manter intacta a floresta em pé a partir de 22 de julho de 2008. Aquele que respeitou o Código Florestal de 1965, respeitando as Reservas Legais em qualquer imóvel conforme o estabelecido foi prejudicado em comparação ao proprietário ou posseiro que agiu ilegalmente.

O Código Florestal de 2012 emprega o termo vegetação nativa ao invés de florestas, abrangendo mais fisionomias, porém não dispõe de caput ou inciso que especifique "vegetação nativa", criando confusão na interpretação de aplicações como, por exemplo, se o corte da floresta secundária pode ou não ser considerado desmatamento ilegal.

O Estado do Pará foi pioneiro ao disciplinar o corte das florestas secundárias, em função do estágio de sucessão, através das Instruções Normativas SEMAS PA 02/2014 e SEMAS-PA 08/2015, as quais consideram somente as florestas secundárias que regeneram após o desmatamento (CHAZDON, 2014).

A floresta secundária representa uma oportunidade para a recuperação de terras antes florestadas ocupadas agora por agricultura itinerante, pastagens e agricultura anual. A legislação ambiental do Estado do Pará assegura a proteção de certas áreas florestadas com estágios de regeneração média a avançada, mas condena a fertilidade natural de outras terras ao esgotamento, devido à destruição

\footnotetext{
${ }^{1}$ Segundo o INCRA (1980), um modulo fiscal possui 80 hectares em Santarém e, entre 70 e 75 hectares em outros municípios da Amazônia Legal Brasileira.
} 
dos bancos de sementes e à poluição dos recursos hídricos e dos horizontes do solo pelo uso de agroquímicos.

Metade das florestas tropicais no Brasil e em todo o mundo é considerada de regeneração natural (FAO, 2010). Em geral, florestas tropicais secundárias têm taxas mais rápidas de sequestro de carbono, com potenciais consequências para o ciclo global de carbono (GRACE; MITCHARD; GLOOR, 2014) e, na região amazônica, correspondem a $22,8 \%\left(173.387 \mathrm{~km}^{2}\right)$ de toda a cobertura vegetal nativa (TERRACLASS-2014, 2016).

Neste estudo as florestas secundárias são compreendidas como formações florestais estabelecidas após o abandono ou pousio de floresta primária (CORLETT, 1994) desmatada por corte raso (CHAZDON, 2014). Outras definições de florestas secundárias referem-se à regeneração após eventos de degradação florestal (como desastres naturais e incêndios) e a expansão das fronteiras de ocupação humana nos países tropicais que levaram à perda de 9,5 milhões de $\mathrm{km}^{2}$ de florestas de $1700 \mathrm{a}$ 1995 (WILLIAMS, 2011, p.372).

A incapacidade em identificar estágios mais antigos de regeneração florestal continua a limitar a compreensão das transições florestais, bem como as causas sociais e econômicas da regeneração florestal. O desenvolvimento de novas ferramentas e aplicações de sensoriamento remoto podem, em breve, tonar possível a avaliação de diferentes modalidades de regeneração florestal em escalas regionais (CHAZDON, 2014).

Este trabalho está estruturado em seis capítulos. A começar pela caracterização do meio na região de Santarém, descrita no Capítulo 2 (seguinte) que pode ser resumido como um sistema de superfícies tabulares e dissecadas assentada sobre arenitos terciários e recoberto por solos resultantes de intemperismo extenso e intenso. Sobre estas superfícies desenvolveram-se principalmente florestas ombrófilas densas e abertas, intercaladas por formações florestais típicas de terrenos de inundação, além de savanas isoladas nos arredores da localidade de Alter- do- Chão.

Sobre os terrenos da região de Santarém há registros de ocupação indígena anterior à chegada dos primeiros europeus paulatinamente substituída pela colonização. O Capítulo 3 resgata como ocorreu a destribalização indígena e a 
ocupação de um território baseado numa economia essencialmente extrativista até a primeira metade do século XX, quando políticas públicas de integração da Amazônia ao restante do Brasil começam a ser planificadas e implantadas, culminando com a construção de estradas e de usinas hidrelétricas, que seriam fundamentais para um intenso ciclo de exploração dos recursos naturais de toda a Amazônia brasileira, iniciada na década de 1970 .

A intercalação de ciclos econômicos tem consequências diretas na relação do homem com a paisagem e novos espaços que podem ser criados, abandonados e modificados. Este estudo mostra que extensas áreas desmatadas no passado para 0 plantio de seringueiras ou de culturas agrícolas malsucedidas, foram abandonadas e recobertas por florestas secundárias. Florestas secundárias são fundamentais ao reestabelecimento de uma floresta madura, mas sua importância não era devidamente reconhecida sob o argumento que a terra, uma vez desmatada, deveria ser sempre tratada como área desmatada nos cômputos de desmatamento. Seja por limitação tecnológica ou interesse econômico o tema ganhou relevância graças à efetividade de ações de combate ao desmatamento ilegal e à procura por áreas propícias à expansão de atividades agropecuárias.

Entre o abandono das áreas degradadas e a abertura de novas clareiras de desmatamento, acontece a regeneração florestal e a formação das florestas secundárias. O Capítulo 4 apresenta as referências teóricas empregadas neste trabalho sobre florestas secundárias, a contribuição que a ciência das mudanças no uso e cobertura da terra pode prestar ao mapeamento de classes de cobertura vegetal, e os instrumentos normativos disponíveis no nível federal e no nível estadual que disciplinam o corte e a conservação de florestas secundárias.

Dentro deste contexto, este trabalho procurou desenvolver um método para reconhecimento e mapeamento de florestas secundárias que rebrotam após desmatamento completo para uso agropecuário, conforme conceituação de Chazdon (2014), adaptada dos trabalhos de Carreiras et al. (2014) e Piazza et al. (2016) numa abordagem que envolve GEOBIA e a mineração de dados para a classificação dos estágios de sucessão de floresta secundária utilizando imagens LANDSAT. Enquanto o método e os procedimentos são descritos no Capítulo 5 , à luz de trabalhos anteriores, no Capítulo 6 os resultados desta experimentação com técnicas de Sensoriamento Remoto são apresentados e discutidos. 
Como é de se esperar, foi identificada a redução na cobertura de florestas primárias nos últimos 30 anos e incremento considerável nas áreas destinadas à agricultura anual ou à pastagem, mas não o mesmo com florestas secundárias. Enquanto as áreas com florestas primárias sempre decrescem, florestas em regeneração apresentam variação positiva ou negativa, seja pelo abandono de áreas anteriormente usadas na agropecuária ou pela redução, como vem se verificando nos últimos anos. A partir destes resultados são apresentadas as considerações finais do trabalho no Capítulo 7 à luz dos desafios atuais para o desenvolvimento sustentável da agropecuária na Amazônia, sem a degradação florestal e o desmatamento.

\subsection{OBJETIVOS}

Desenvolver uma abordagem para identificar e analisar mudanças na extensão de florestas secundárias formadas após o desmatamento e processos de degradação florestal.

\subsection{OBJETIVOS ESPECÍFICOS}

- Expor como a evolução do uso e ocupação da terra contribuiu para a formação de florestas secundárias na região de Santarém e na Amazônia Brasileira;

- Apresentar o referencial teórico referente à definição de floresta secundária, e a legislação existente sobre desmatamento e conservação de floresta secundária conforme o estágio de sucessão;

- Identificar as áreas recobertas por florestas secundárias de acordo com o referencial teórico e jurídico considerado;

- Identificar para a área de estudo, duas classes de sucessão secundária (SS) após o corte raso, e uma classe de floresta madura;

- Avaliar a aplicação combinada de Análise de Imagens baseada em Objetos Geográficos (GEOBIA), mineração de dados e geoprocessamento como abordagem válida para identificação dos estágios de sucessão florestal na Amazônia brasileira. 


\subsection{JUSTIFICATIVA}

Para abordar as diferentes questões que emergem das interações entre homem e ambiente, Kates et al. (2001) sugere incorporar esquemas e técnicas novas ou melhoradas. Isto inclui métodos observacionais, como o sensoriamento remoto, e abordagens inversas que, a partir de um cenário não desejado, trabalham de forma retroativa para identificar caminhos que levem estas interações a trajetórias sustentáveis.

O mapeamento dos estágios de sucessão florestal e da cobertura florestal pretérita estabelece esta prerrogativa ao oferecer dados valiosos para a identificação de terras aptas para a agricultura comercial sustentável, para a agricultura familiar e atividades extrativistas, mas especialmente para identificação de áreas favoráveis à recomposição florestal e à prestação de serviços ambientais essenciais, como a recarga de aquíferos e a formação de corredores para a fauna silvestre.

Como área de estudo, a região de Santarém é uma boa representação da construção de uma paisagem modelada ao longo dos principais ciclos econômicos extrativistas da Amazônia, antes da expansão recente do capital em toda a região, como atesta a significativa extensão das florestas secundárias registrada nas imagens de satélite mais antigas usadas neste estudo, desde o início da operação do sensor LANDSAT-5 em 1984. 


\section{CARACTERIZAÇÃO DA ÁREA DE ESTUDO}

Os dias são alegres [em Santarém], seu alvorecer é lindo e as suas praias são soberbas. O espetáculo que se repete todas as tardes, durante o arrebol, é sempre variado e majestoso. Nunca se deita o sol no Tapajós senão cercado de ouro e púrpura... seu clima, posição e uberdade dos terrenos convidam a emigração a fazer ahi um núcleo, do qual grandes e importantes resultados se devem colher.

(RODRIGUES, 1875, p.6)

\subsection{LOCALIZAÇÃO}

A área de estudo está localizada na região Oeste do Pará, entre os paralelos $1^{\circ} 59^{\prime} 56^{\prime \prime}$ e $3^{\circ} 57^{\prime} 52^{\prime \prime}$ de latitude sul e entre os meridianos $5^{\circ} 05^{\prime} 36^{\prime \prime}$ e $53^{\circ} 44^{\prime} 07^{\prime \prime}$ de longitude oeste. A proposta deste trabalho abrange $11.124 \mathrm{~km}^{2}$ de áreas classificadas como zonas de Expansão, Consolidação e Críticas no mapa de gestão do ZEE-BR163 (VENTURIERI, 2008) na região do planalto de Santarém, tendo os seguintes limites:

- norte: rio Tapajós e rio Amazonas;

- sul: limites municipais dos municípios de Santarém e Mojuí dos Campos;

- oeste: Floresta Nacional do Tapajós;

- leste: rio Curuatinga, nos municípios de Prainha e Uruará.

As áreas protegidas constituídas não foram consideradas no escopo deste trabalho, pois é assumido que recebem menor pressão de desmatamento e degradação, em comparação com as áreas florestadas remanescentes em terras privadas, sobre as quais se dispõe apenas do atual código florestal (BRASIL, lei 12.651 de 2012) e da lei de crimes ambientais (BRASIL, lei 9.605 de 1998) como documentos normativos.

$\mathrm{Na}$ Tabela 1 é apresentada a área total dos municípios interseccionados pela área de estudo proposta. 
Tabela 1 - Computo de área total dos municípios onde está a área de estudo

\begin{tabular}{|c|c|c|c|c|}
\hline Município & $\begin{array}{l}\text { Área município } \\
\left(\mathrm{km}^{2}\right)^{1}\end{array}$ & $\begin{array}{l}\text { Área de estudo } \\
\left(\mathbf{k m}^{2}\right)^{2}\end{array}$ & $\%$ município ${ }^{3}$ & $\begin{array}{l}\% \text { área de } \\
\text { estudo } 4\end{array}$ \\
\hline Belterra & $4.400,36$ & $1.362,06$ & $31,0 \%$ & $12,2 \%$ \\
\hline $\begin{array}{l}\text { Mojuí dos } \\
\text { Campos }\end{array}$ & $4.994,47$ & 4994,47 & $100,0 \%$ & $44,9 \%$ \\
\hline Santarém & $17.903,51$ & $3.059,89$ & $17,1 \%$ & $27,5 \%$ \\
\hline Prainha & $14.826,02$ & 527,52 & $3,6 \%$ & $4,7 \%$ \\
\hline Uruará & $10.816,63$ & $1.180,18$ & $10,9 \%$ & $10,6 \%$ \\
\hline Total & $52.939,81$ & $11.124,12$ & $21,0 \%$ & $100,00 \%$ \\
\hline $\begin{array}{l}\text { Dados calcul } \\
1 \text { dado refere } \\
2 \text { dado refere } \\
3 \text { porcentage } \\
4\end{array}$ & $\begin{array}{l}\text { área total do muni } \\
\text { área do município } \\
\text { área do município } \\
\text { arcela de cada mı }\end{array}$ & Ia 21 Sul, Datum SIF & AS 2000. & \\
\hline
\end{tabular}

Fonte: IBGE. Limites municipais do Brasil (2015).

Uma leitura mais detalhada da Tabela 1 permite constatar qual a porcentagem da área que cada município cobre dentro da área de estudo na coluna "\% município" e também o peso de cada parte na composição do total na coluna "\% área de. estudo".

A Figura 1 apresenta a localização geral da área de estudo e sua extensão, com destaque para os pontos geográficos limitantes e o desmatamento acumulado até 2016 com os dados PRODES (INPE, 2016). 


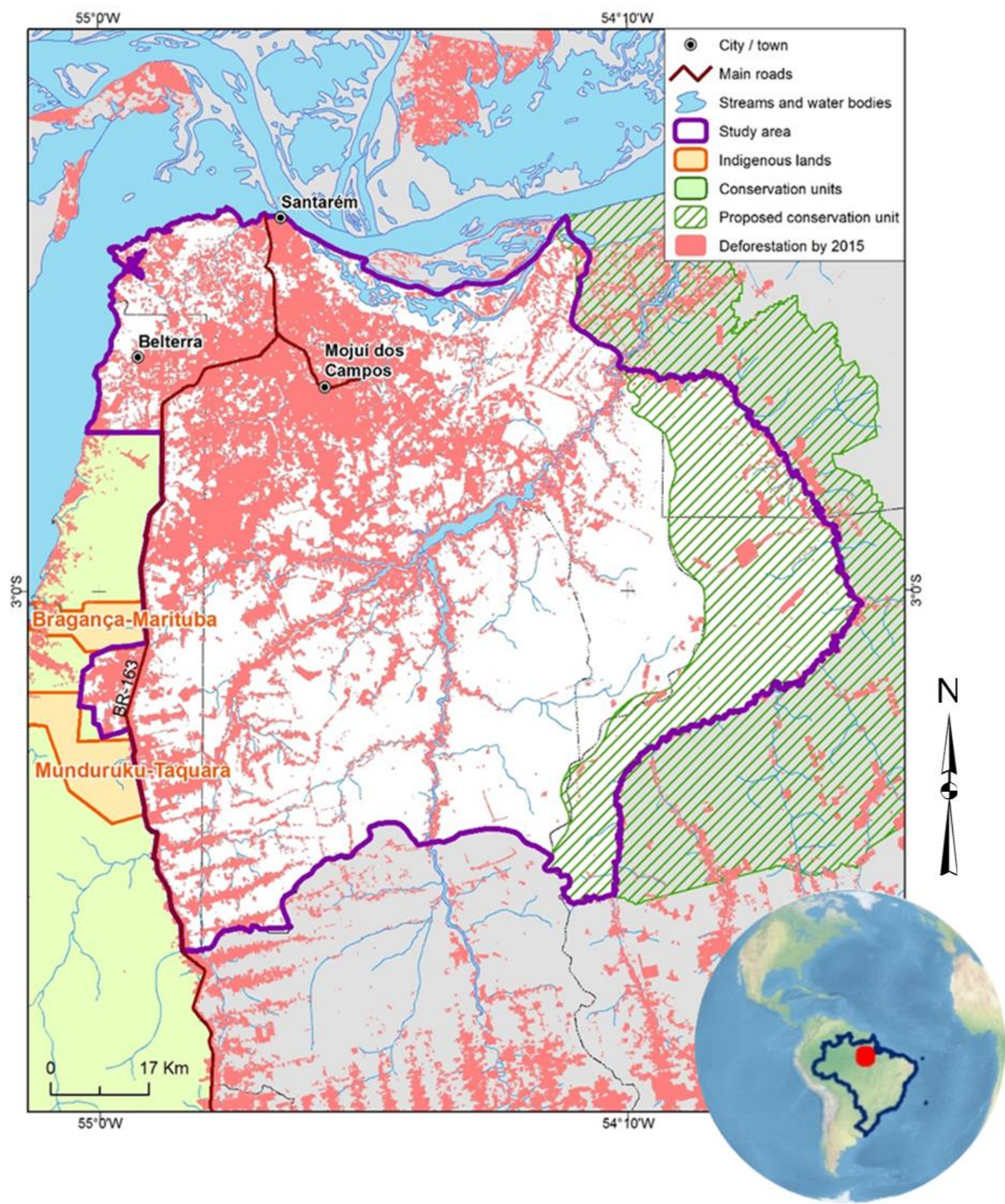

Figura 1 - Localização e extensão da área de estudo

Fontes:

Desmatamento: PRODES (INPE, 2016);

Limite da Floresta Nacional dos Tapajós: ICMBIO (2016);

Limite das terras indígenas. FUNAI (2013);

Limite de unidade de conservação proposta: ZEE-BR-163 (VENTURIERI, 2008);

Limites municipais: Malha Digital Municipal do Pará (IBGE, 2013);

Estradas e hidrografia: Banco de Dados do Brasil ao Milionésimo (IBGE, 2013). 


\subsection{CARACTERIZAÇÃO FÍSICA DA ÁREA DE ESTUDO}

Santarém possui uma paisagem modelada através de vários ciclos econômicos, como o do cacau no século XVIII, seguido pela economia da borracha entre o século XIX e o primeiro quarto do século $X X$, sucedido por projetos de colonização relacionados às novas rodovias que cortaram a Amazônia de leste para oeste, e do sul para o norte. Esta nova fronteira econômica deixou marcas na paisagem anteriormente ocupada por povos indígenas, ribeirinhos e quilombolas, estando hoje recoberta por agricultura anual, por pastagens e por floresta secundária.

A fisiografia desta região é dominada por interflúvios tabulares (platôs) e superfícies aplainadas relacionadas à unidade de mapeamento geomorfológico Planalto Tapajós-Xingu (RADAMBRASIL, 1976). O embasamento destes terrenos é constituído por arenitos, argilitos e siltitos atribuídos à Formação Alter do Chão (VÁSQUEZ; ROSA-COSTA, 2008), uma unidade litológica formada por depósitos fluviais cretáceos ao longo de toda a calha da Bacia Sedimentar do Amazonas.

A cobertura superficial do Planalto Tapajós-Xingu é dominada por Latossolos Amarelos de textura argilosa (argila Belterra), ocorrendo também Neossolos Quartzarênicos (Areias Quartzosas) nas colinas residuais entre a localidade de Alter- do-Chão e a cidade de Santarém. Cabe destaque também às manchas de Terra Preta de Índio (TPI) nos assentamentos humanos mais antigos da Amazônia, conforme descrito por Nimunedajú (1952), Sombroek (1966) e por Kern et al. (2003).

O Planalto Tapajós-Xingu é limitado pela planície de inundação do rio Amazonas e por planícies aluvionares interiores da rede hidrográfica comandada pelo rio Curuá-Una e outros tributários diretos dos rios Amazonas e Tapajós. A litologia destes terrenos é constituída por areias, argila e cascalho com solos incipientes (Neossolos Flúvicos) ou hidromórficos (Gleissolos).

Segundo a classificação climática de Köppen, a região situa-se sob clima equatorial úmido (Am), com uma estação seca bem definida e outra com elevados índices pluviométricos e temperaturas médias superiores a $18^{\circ} \mathrm{C}$ em todos os meses, controlado pela ação dos ventos alísios, por baixas pressões equatoriais e pela oscilação da Zona de Convergência Intertropical (ZCIT).

Como se trata de uma região de encontro dos alísios do hemisfério norte com os do hemisfério sul. A maior parte das precipitações que aí ocorrem são chuvas de convecção. A situação continental da região, distante cerca de 700 quilômetros do 
Oceano Atlântico e com altitudes entre 20 metros e 150 metros, confere à área padrões climáticos sazonais - uma estação de maior precipitação, e outra menos intensa:

- de dezembro a maio: quando ocorre o avanço das correntes de baixa pressão provenientes do continente sul-americano durante 0 período das chuvas; e

- de junho a novembro: quando ocorre o avanço das correntes de alta pressão durante a estação de menor precipitação. Período do ano com maiores temperaturas médias e máximas diária, e também menor diferença entre a temperatura mínima e a máxima.

Os tipos de vegetação dominantes na área de estudo são: a floresta ombrófila densa sobre os interflúvios tabulares, com $65,8 \%$ de ocorrência em toda a área de estudo (Tabela 2), com menor extensão de florestas secundárias e áreas de transição, e savana-parque nas superfícies aplainadas; áreas antropizadas e florestas secundárias em áreas desmatadas, originalmente recobertas por floresta ombrófila densa e, com menor expressão geográfica, as floresta ombrófila aberta e formações pioneiras em planícies de inundação.

Tabela 2 - Computo das fitofisionomias na área de estudo

\begin{tabular}{|c|l|c|c|}
\hline Código & Categoria & $\begin{array}{c}\text { Area } \\
(\mathbf{k m})\end{array}$ & $\%$ \\
\hline Dbe / Dse & $\begin{array}{l}\text { Floresta Ombrófila Densa Terras Baixas e } \\
\text { Submontana }\end{array}$ & 731,691 & 65,8 \\
\hline Vss / Vse & $\begin{array}{l}\text { Vegetação secundárias (com ou sem palmeiras) em } \\
\text { floresta ombrófila densa }\end{array}$ & 275,993 & 24,8 \\
\hline Acc / Ap/ AA & Áreas antropizadas & 26,178 & 2,4 \\
\hline Asc & Floresta Ombrófila Aberta Submontana com cipós & 23,518 & 2,1 \\
\hline SOc & $\begin{array}{l}\text { Contato savana / floresta ombrófila / vegetação } \\
\text { secundária }\end{array}$ & 21,936 & 2,0 \\
\hline Spf & Savana Parque com ou sem floresta de galeria & 4,768 & 0,4 \\
\hline Pahs & Formações pioneiras & 4,568 & 0,4 \\
\hline Da & Floresta ombrófila densa aluvial & 2,857 & 0,3 \\
\hline & Massa d'água & 20,325 & 1,8 \\
\hline
\end{tabular}

Fonte: Adaptado do Projeto RADAMBRASIL (1976) e AMBIDATA (AMARAL et al., (2013).

O Mapa de Vegetação da área de estudo (Mapa 1) foi elaborado a partir da adaptação do mapa fitogeográfico da Folha SA.21 do Projeto RADAMBRASIL (1976) disponibilizado digitalmente pelo projeto AMBIDATA (AMARAL et al., 2013). 


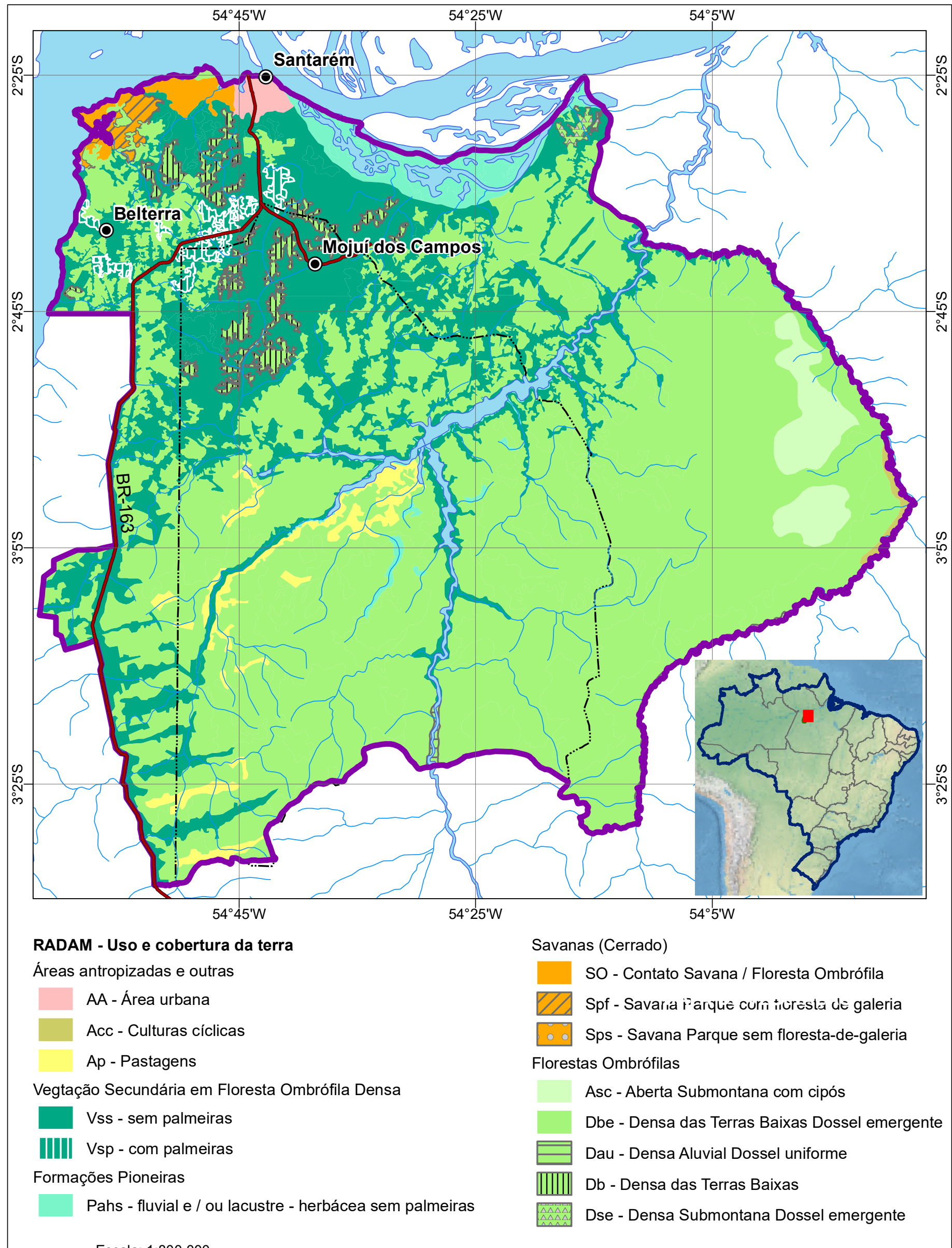

Escala: 1:800.000

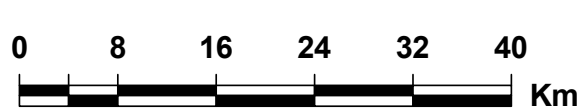

Sistena de Coordenadas Geodésicas Datum: SIRGAS 2000

Fontes:

Vegetação: RADAMBRASIL (1982); INPE, AMBIDATA (2013)

Base: Brasil ao milionésimo. IBGE (2015)
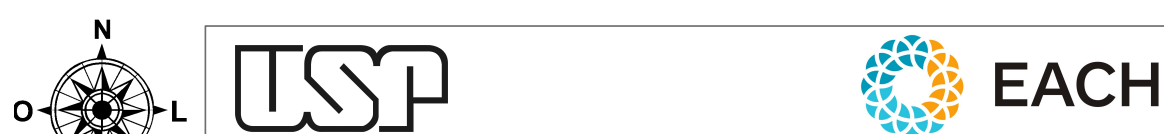

Regeneração florestal após o desmatamento: estudo da região de Santarém Diego Pinheiro de Menezes

Mapa 1 Vegetação da Área de Estudo

Dissertação de mestrado 


\section{A EVOLUÇÃO DO USO E DA RELAÇÃO SOCIAL COM A TERRA NA REGIÃO DE SANTARÉM}

Nossa aparente incapacidade ou relutância em resistir à fragmentação [do espaço e do conhecimento] e à efemeridade [das relações humanas] sugere uma condição na qual algo está sendo feito para nós por forças além de nosso controle.

(HARVEY, 1990, p.431)

\subsection{OCUPAÇÃO INDÍGENA}

Antes da colonização portuguesa as terras entre o vale do rio Tapajós e o vale do rio Curuá-Una foram ocupadas pelo povo Tapajó e pelo povo Mundurucu, de acordo com o mapa etno-histórico de Nimuendaju (1987). Este mapa foi produzido com base nos primeiros relatos datados do século XVII e do século XVIII como o mapa jesuíta do Padre Samuel Fritz datado de 1691 (Figura 2), o mapa etnolinguístico de Von Martius (1867), e os relatos de Henri Coudreau em "Voyage au Tapajós" sobre sua missão realizada entre 1895 e 1896, entre outros.

Vestígios destes povos ainda são encontrados nessa região, especialmente em fragmentos de cerâmica e através da identificação das Terras Pretas de Índio, indicando onde houve povoamentos indígenas pretéritos. O clima tropical e a efemeridade dos objetos de construção, ferramentas e ornamentos produzidos a partir de matéria orgânica (já que na região não havia materiais metálicos e líticos de fácil exploração) torna difícil reconstituir as culturas pré-históricas amazônicas, pois como aponta Meggers (1990), apenas a cerâmica é abundante e duradoura, apesar dos poucos vasos complexos já encontrados, de modo que as principais evidências são compostas por fragmentos em sua maioria não decorados. 


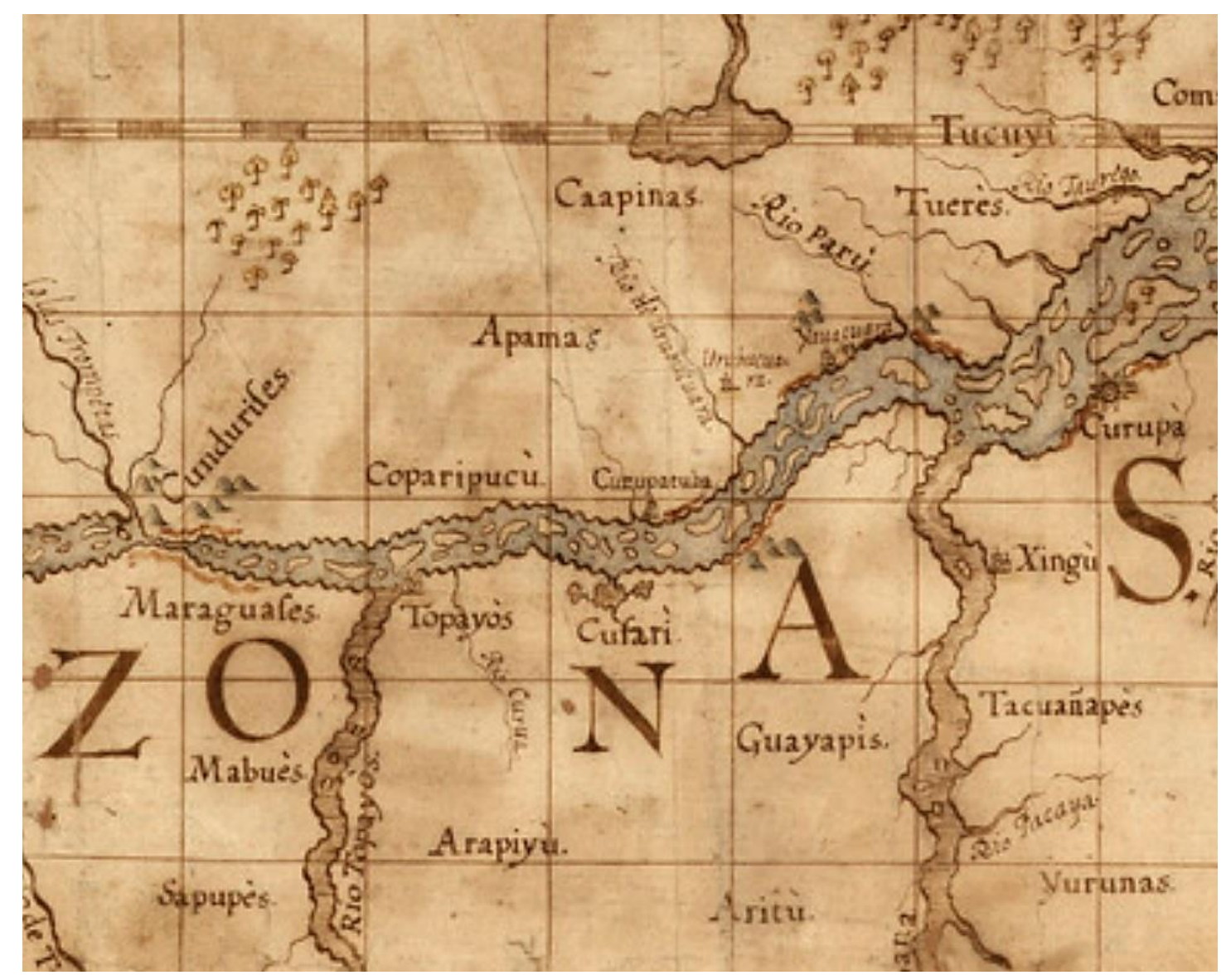

Figura 2 - Fragmento de "Mapa Geographica del rio Maranõn o Amazonas".

Mapa produzido por Fritz (1691). Um dos mais antigos registros etno-histórico disponível sobre a ocupação indígena no vale do rio Amazonas.

Os primeiros relatos sobre as Terras Pretas de Índio foram feitos em estudos etnográficos sobre aldeias indígenas no vale do Xingu e no vale do rio Tapajós, como em Nimuendaju (1948), que identificou numa aldeia próxima à Volta Grande do Xingu terras pretas entre solos amarelos, com distribuição de fragmentos cerâmicos e com matéria orgânica formada de cinzas de fogueiras para preparo de alimentos, além de restos de dejetos humanos e de depósito de urnas funerárias. O trabalho de Sombroek (1966) é referência no reconhecimento e descrição destes solos, confirmando a sua alta fertilidade característica em comparação aos Latossolos e Argissolos típicos da Bacia Amazônica.

A datação das Terras Pretas de Índio, como em Glaser (2002), permitiu concluir que a ocupação humana na região Amazônica remonta há pelo menos $8.000 \mathrm{AP}$, embora não haja evidências que o povo Tapajó e o povo Mundurucu estivessem assim constituídos por todo este período; assumindo que grupos humanos se sucederam e 
deram lugar a outros através de movimentos migratórios ou pelo seu desaparecimento por doenças ou guerras entre tribos. A chegada do colonizador português, entre o século $X V I$ e o século $X V I I$ foi determinante neste processo, mas antes de sua chegada é possível resumir a ocupação do Baixo Amazonas, conforme a reconstituição proposta por Simões (1982), em fases distintas, a saber:

- 10.000 AC - 1.000 AC: Caçadores e coletores pré-cerâmicos onde hoje estão os Estados de Mato Grosso, Pará, Piauí e Rondônia;

- 1.100 AC - 200 AC: Agricultores incipientes na ilha de Marajó e região do Baixo Amazonas; e,

- 0 - 1.600 AD: Horticultores de floresta tropical por toda a bacia Amazônica.

Estes grupos horticultores eram de etnias distintas no tempo anterior à colonização, conforme Simões (1982), mas em comum praticavam a agricultura itinerante, conhecida por coivara, tendo a cultura da mandioca e milho como base alimentar e a caça e pesca como complemento. Não há estudos sobre a agricultura dos Tapajós, hoje extintos, mas Frikel (1959) estudou em campo a agricultura dos Mundurucu que habitavam o médio Tapajós e que, apesar da condição nômade abandonada e da introdução de algumas práticas do colonizador, como o uso do terçado, ainda aplicavam conhecimento empírico de seus antepassados.

A agricultura dos Mundurucu, segundo Frikel (1959), seguia um processo de trabalho influenciado pelo clima, época do ano, declividade do terreno, e era baseada em conhecimento empírico e feita em uma sequência de desenvolvimento da roça, assim descrita por Protássio Frikel:

1. escolher o terreno e a qualidade da terra;

2. determinar o tamanho e a forma do novo roçado;

3. brocar o terreno;

4. derrubar a mata;

5. queimar o material derrubado;

6. encoivarar e queimar a coivara;

7. cavar e plantar;

8. primeira e segunda limpeza de roçado;

9. "desmanchar" o roçado - safra;

10. replantar a roça. 
Apesar da derrubada e queima, esta é uma agricultura em desenvolvimento, com paralelo ao praticado pelo povo Dayak na Indonésia, descrito por Chazdon (2014) e pelos povos da América Central antes da conquista Espanhola. Na Europa Ocidental é possível traçar um paralelo com a agricultura praticada no neolítico (entre $4.000 \mathrm{AC}$ e 3.000 AC), conforme descreveu Williams (2011, 45-46), com rotações de culturas e pousio, embora estes grupos utilizassem da madeira para construção de habitações e dominassem a pecuária.

Neste processo de desenvolvimento da roça, a escolha do terreno e o controle da queima são as etapas onde o indígena mais aplica o seu conhecimento empírico. Segundo Frikel (1959), os terrenos planos, em topos ou várzeas, eram preteridos por suas condições de drenagem, havendo preferência por terrenos levemente inclinados recobertos por Terra Preta de Índio (reconhecidamente o solo mais fértil), onde era possível fazer qualquer roça, ainda que reconhecessem terras de textura arenosa e "barrenta" onde, em síntese, plantavam apenas mandioca e macaxeira.

Nas roças indígenas (Figura 3) os tubérculos ${ }^{2}$ são plantados na área central da roça e, ao redor, - os demais gêneros, como o milho, o jerimum e feijões, entre outros. O preparo da roça compreendia selecionar, para uma roça nova, uma árvore maior que as demais que, quando derrubada, levasse junto outras árvores parcialmente abatidas, formando uma clareira de até um hectare.

Uma vez aberta, a clareira é abandonada por dois a três meses para que os tocos e rebrotas remanescente sejam secos pelo sol, para a queima efetiva na estação de menor precipitação, em dias de pouco vento. A coivara propriamente dita consiste em recolher galhos e pedaços de troncos parcialmente queimados, colocá-los sobre os tocos maiores fumegantes, para reduzir às cinzas este material e limpar o terreno para o plantio.

\footnotetext{
2 Mandioca e macaxeira (Manihot esculenta Crantz) e cará-doce (Dioscorea trifida L.). A distinção entre mandioca e macaxeira é etnológica e refere-se, respectivamente, às variedades com maior e menor concentração de ácido cianídrico (DUFOUR, 1988). Segundo Arroyo-Kalin (2010), a distinção de variedades mansas e bravas da Manihot esculenta Crantz pode estar relacionada à agricultura praticada por sociedades sedentárias na Amazônia no período pré-Colombiano. Para o autor, as variedades mansas foram dispersas amplamente na Amazônia, enquanto o crescimento populacional e o sedentarismo favoreceram o desenvolvimento de variedades bravas em roças afastadas das aldeias, prevalecendo as espécies mais produtivas e menos suscetíveis à pragas e doenças.
} 


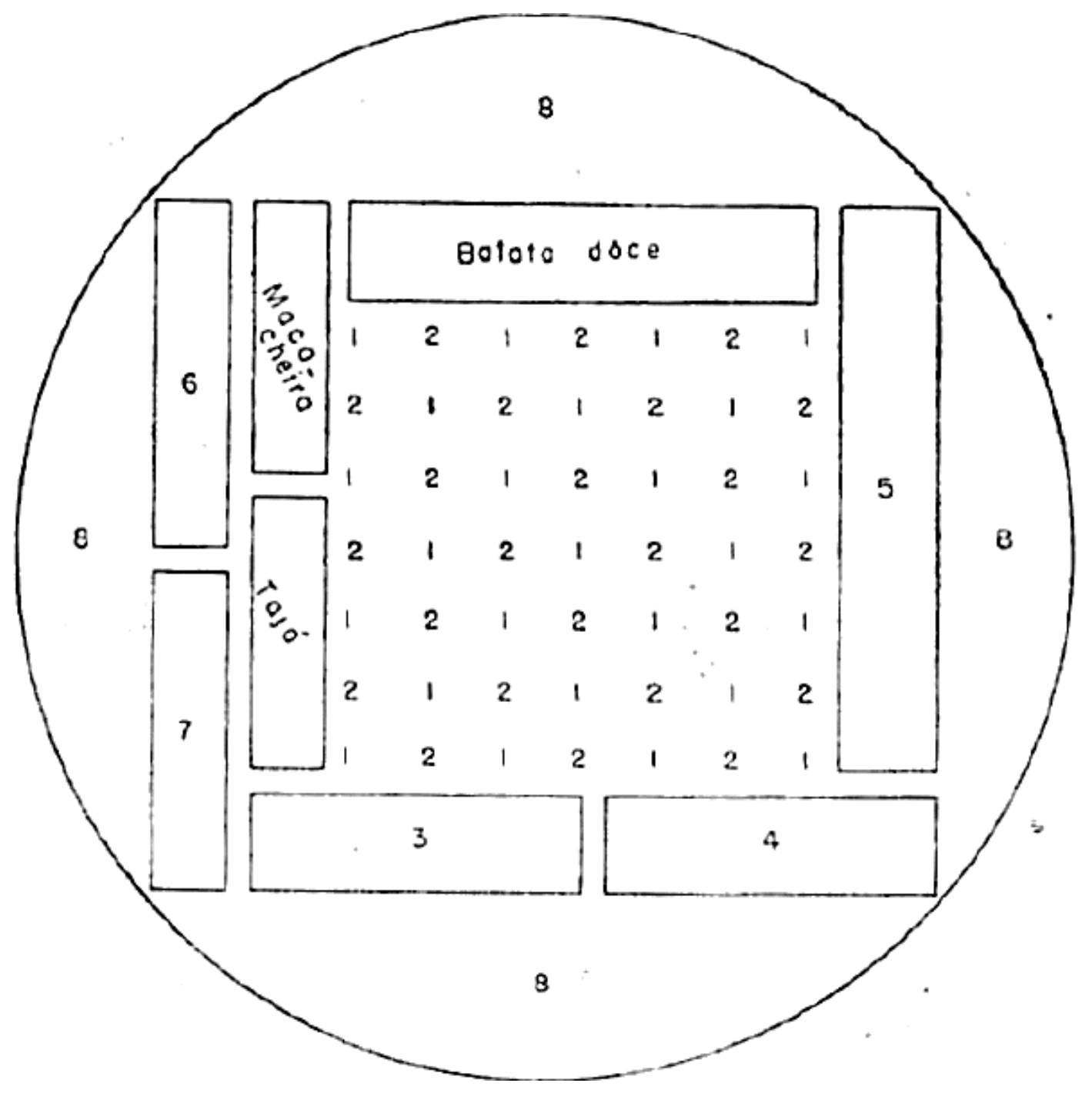

Figura 3 - Diagrama representativo de roça Mundurucu.

Onde: 1- maniva (mandioca); 2- cará; 3- cana; 4- abacaxi; 5- timbó; 6- arroz; 7- milho; 8- feijão, fava, jerimum, além de batata doce, tajá e macaxeira como indicado.

Fonte: Frikel (1959).

Esta prática agrícola ainda hoje pode ser observada em terras indígenas na Amazônia brasileira. Como exemplo a Figura 4 mostra o recorte de uma imagem do sensor SPOT 5 com a aldeia Mundurucu "Sai-Cinza" e as roças circulares (ou elípticas) ao redor. Apesar do termo, as roças circulares não possuem formas regulares como um pivô de irrigação, mas denotam segundo Frikel (1959) uma técnica de baseada na abertura gradual da roça e na figura central do plantio da mandioca (sobretudo da variedade brava) e na figuração periférica dos demais gêneros como mostra a Figura 5. 


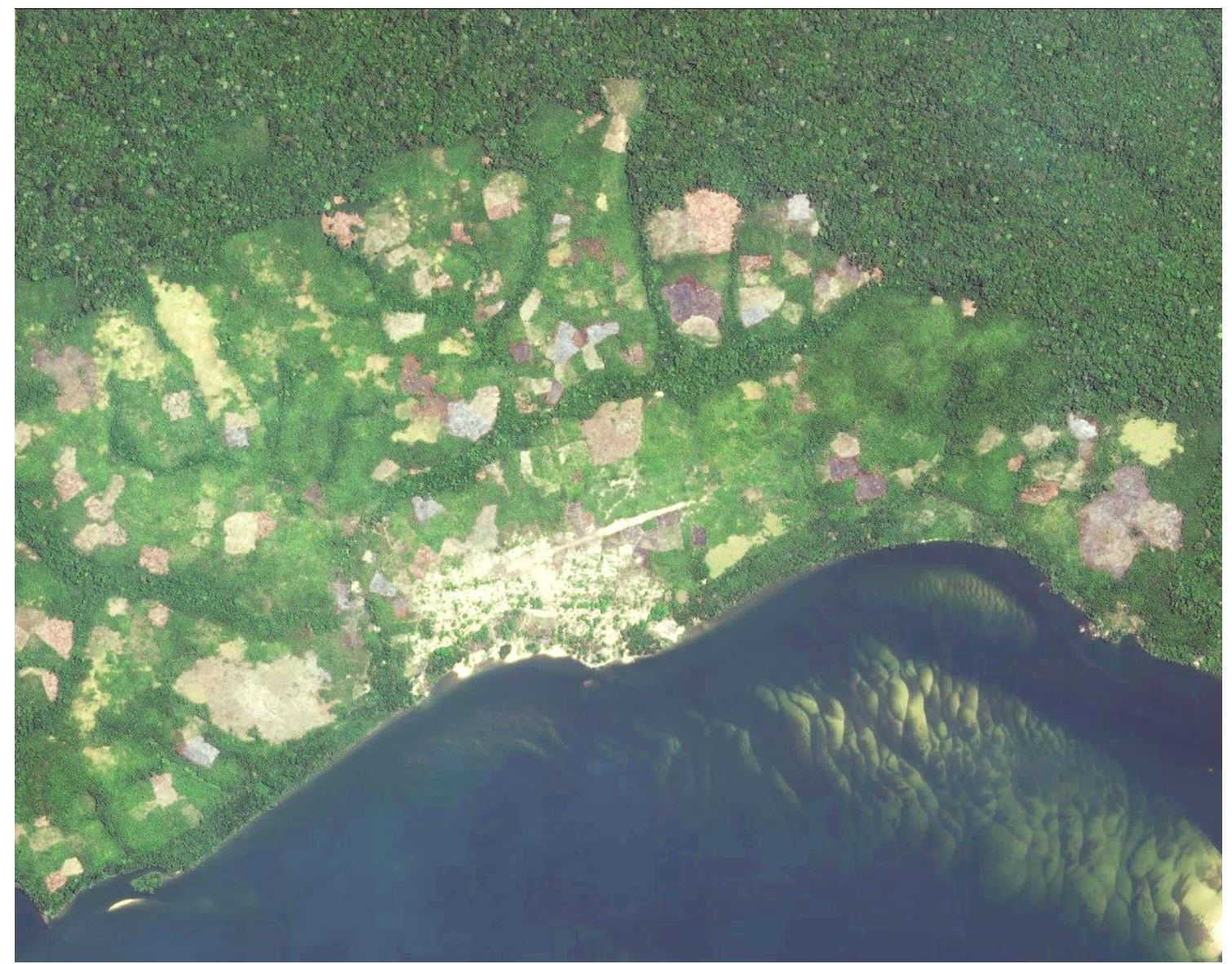

Figura 4 - Aldeia e roça mundurucu na Terra Indígena “Sai-Cinza”.

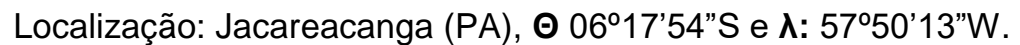

Fonte: BING Maps. Digital Globe, sensor World View 2. Data: 10/10/2010.

A destribalização e a dispersão de populações indígenas para os interflúvios distantes das cidades e vias primárias de penetração na Amazônia brasileira (as calhas dos grandes rios) levaram ao abandono das roças e à ocupação destas por descendentes, miscigenados e fluxos de migrantes que chegariam não só em Santarém conforme aponta Valbuena (2008) como em outras frentes de ocupação na Amazônia

O modo de vida dos indígenas que habitaram Santarém, bem como outras vastas áreas da Amazônia, não incorporou desenvolvimento tecnológico avançado e a agricultura praticada dispensava a estocagem de alimentos por longos períodos, tornando necessário o desenvolvimento de um sistema de trocas. Havia disputa de território entre povos distintos, mas não havia relato de moléstias e de fome. Apesar da presença do cacique e de funções bem definidas numa aldeia, os povos indígenas tinham livre arbítrio. 


\subsection{PERÍODO COLONIAL: DA FUNDAÇÃO DA VILA DE SANTARÉM ATÉ A CABANAGEM}

Os núcleos militares-coloniais e as missões jesuítas foram as primeiras manifestações de colonização europeia na Amazônia. Estabelecidas pelos portugueses entre o século XVII e o século XVIII quando, a partir de Recife e Salvador, os portugueses chegaram à Amazônia para afastar os concorrentes ingleses, holandeses e franceses procedentes das Antilhas, para conquista de novas terras e em busca de "drogas do sertão". Assim, surgiram os primeiros núcleos nas principais desembocaduras e confluências de rios: São Luís (1612), Belém (Forte do Presépio, 1616), Santarém (1661), Manaus (Forte de São José, 1669), e Macapá (Forte de São José, 1758).

Outro aspecto relacionado à defesa da vasta colônia foi o emprego do nome de cidades portuguesas em referência para as novas povoações no Grão-Pará, como Belém Almeirim, Bragança, Óbidos e Viseu e, tal como na margem direita do baixo Tejo, há uma cidade Santarém também na margem direita do baixo Amazonas, foi fundada uma vila homônima, no entanto sem referência à Santa Iria (ou Irene) de Tomar, não havendo igrejas católicas nesta cidade em culto a ela.

De acordo com Beozzo (1984), o processo de conquista da coroa portuguesa na região Amazônica só foi possível graças ao amansamento e dominação da mão de obra indígena. Assim, a partir do governo Manoel de Souza na capitânia do GrãoPará, organizaram-se excursões para o "resgate" de indígenas, contando com a intermediação dos jesuítas. Deste modo, em 1661 chegou ao Tapajós, a mando do Padre Antônio Vieira, o Padre João Felipe Bettendorf, considerado o fundador do povoamento de Santarém, a qual viria a ser elevada à categoria de cidade em 1848.

As missões jesuítas foram o principal elemento de colonização e amansamento indígena da Amazônia, coexistindo com a expansão mercantil portuguesa na colônia, até 1757. Por ordem do Marquês de Pombal, a presença jesuíta (e marcas como a língua Nheengatu) é gradativamente expulsa da região e substituída pelo Diretório dos Índios (CLEARY, 1998), acelerando a destribalização e o trabalho compulsório indígena. Haviam três missões jesuítas em 1840 em toda a Amazônia. Segundo Martins (2010), a Coroa, arrecadadora dos tributos do tráfico negreiro, ao proibir a escravidão indígena confirmou e consolidou um senhorio rentista que a fez sócia 
maior da escravidão negra e assegurou por longo tempo o caráter meramente residual das determinações capitalistas dos negócios coloniais.

O produto da destribalização e do trabalho compulsório indígena, para Moreira Neto (1988) é o Tapuio, que o define como um "índio genérico", etnicamente aculturado ao branco, ausente de características particulares e vulneráveis, portanto, à violência política e ao desinteresse político crescente, a partir do período pombalino. A figura do Tapuio desapareceria a partir de $1870 \mathrm{com}$ a chegada de migrantes para o trabalho nos seringais.

Marquês de Pombal também ordenou a criação da Companhia Geral de Comércio do Grão-Pará e Maranhão em 1755, que gozaria de monopólio do comércio de mercadorias (algodão, cacau, madeira e especiarias) e de escravos em toda a província, até a década de 1780 . As décadas seguintes testemunharam o declínio do regime colonial e, regionalmente, o declínio do comércio do cacau silvestre. $A$ independência do Brasil em 1822 e a adesão do Grão-Pará em 1823 pareciam levar à diversificação econômica baseada no trabalho compulsório do indígena e do negro.

No entanto, a interrupção do tráfico negreiro marítimo imposto pelos britânicos ao Brasil em 1831, restringindo e encarecendo o mercado de escravos em todo o país, e a instabilidade política do período regencial (1831-1840), levaram à eclosão, em Belém, da Cabanagem (1835 e 1839). Foi uma rebelião que irradiou para o interior da província e contou com a participação da população marginalizada (tapuios, caboclos e escravos descontentes). Dentre os 130.000 habitantes da província do Grão-Pará na época, cerca de 30.000 morreram, sendo 400 destes mortos em Santarém, segundo Jackson (2008).

Segundo Cleary (1998), a Cabanagem foi a mais longa rebelião contra o governo imperial e que impactou a maior unidade do território nacional. Foi também a única rebelião onde os rebeldes tomaram toda a máquina de governo em qualquer período no nível provincial, o único em que o governo rebelde negociou com forças estrangeiras, e o único em que os rebeldes ocuparam a capital provincial.

Dentre outras consequências da Cabanagem, fugitivos da rebelião fixaram-se em terras não reclamadas e quilombos, outros trabalhadores livres começaram a se dedicar à extração do látex, atraídos pela alta no preço da borracha na década de 1840. Segundo Weinstein (1993), a formação desta população contrariou, portanto, os interesses da elite branca proprietária de terras pela formação de um contingente 
não sujeito diretamente ao seu controle e pela falta de mão de obra em suas fazendas em favor dos seringais.

\subsection{A ECONOMIA DA BORRACHA: BASES DA ESTRUTURA ECONÔMICA ATUAL}

A borracha foi apresentada ao mundo por Charles Marie de la Condamine. Ele foi um naturalista francês que percorreu a Amazônia entre 1743 e 1745, de Quito a Caiena, e publicou a obra "Relation abrégée d'un voyage fait dans l'intérieur de l'Amérique méridionale", publicado pela Academia Real de Ciências da França. Segundo Safier (2009), para escrever "Relation abrégée" La Condamine recolheu, sem citar fontes, mapas e relatos de jesuítas como o mapa do jesuíta Samuel Fritz (Figura 2) para confecção de um mapa mais detalhado do Rio Amazonas (Figura 5), bem como toda informação relevante de escravos e indígenas, os quais descreve pejorativamente:

[...] o homem abandonado à simples natureza, privado da educação e da sociedade, difere pouco da besta.

(LA CONDAMINE, 1745, p.52).

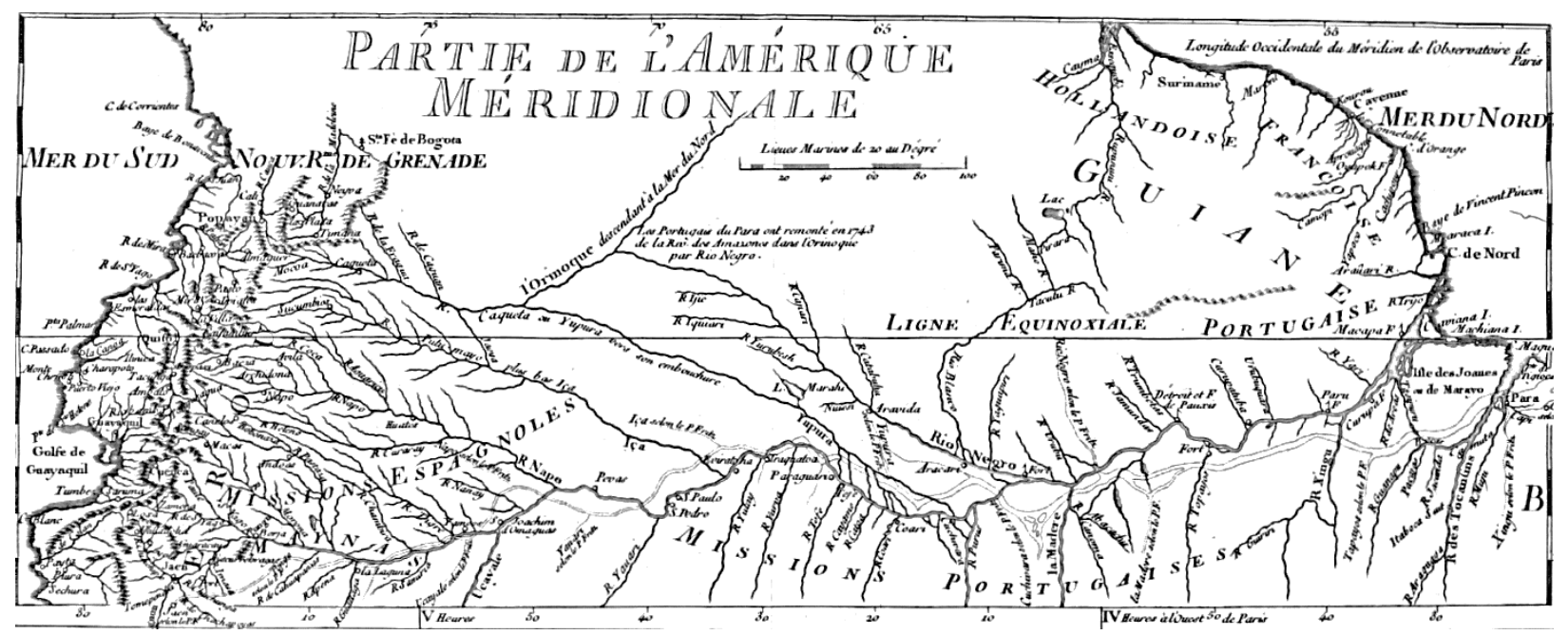

Figura 5 - "Carte du Cours du Maragnon ou de la Grande Riviere des Amazones"

Fonte: La Condamine (1745). 
La Condamine observou que os nativos extraíam um líquido leitoso aproveitado em múltiplos usos, o caotchu (madeira que chora em quecha) ou, em francês, caoutchouc. Ele não foi o primeiro a escrever sobre a borracha, mas teve papel primordial em sua promoção; não apenas importou em pequenas quantidades como também tentou fabricar roupa à prova d'água (WEINSTEIN, 1993).

A borracha tinha reconhecida maleabilidade, elasticidade e impermeabilidade, mas alta sensibilidade à mudança de temperatura. $O$ processo de vulcanização aperfeiçoado por Charles Goodyear, em 1839, tornou a borracha resistente ao calor e ao frio, ampliando a gama de suas aplicações, e a demanda mundial por borracha, que cresceria também com o aparecimento da bicicleta em 1890 e do automóvel em 1900 (WEINSTEIN, 1993).

A borracha silvestre foi uma mercadoria essencial para a primeira revolução industrial na Europa e nos Estados Unidos no século XIX, até o advento da borracha sintética no século XX. No entanto há um ponto em comum a todos os países que adotaram a heveicultura: a mão de obra servil - o seringueiro mal pago e em condições análogas a da escravidão. Outro ponto em comum foram as estradas de rodagem e as ferrovias de ligação das áreas produtivas aos portos, como é o caso das ferrovias Madeira-Mamoré e Niger-Conacry

A industrialização e o liberalismo econômico causaram o crescimento acentuado do comércio internacional de mercadorias durante o Imperialismo (18701914). Era o apogeu das companhias britânicas no comércio de mercadorias, logo rivalizado pelo crescente interesse americano, alemão e japonês no acesso às novas oportunidades comerciais, com o fim dos sistemas imperais fechados de comércio e da disseminação do trabalho livre assalariado.

Para a Amazônia foi um ciclo próspero, enquanto a região monopolizou o suprimento mundial de borracha até a grande queda em 1920 (SANTOS, 1980), como exemplifica a Figura 6, provocada pelo sucesso da introdução da seringueira no sudeste asiático. A efemeridade deste ciclo não se explica apenas pela dependência do capital externo, mas também pela inação do Estado em práticas protecionistas, pela estrutura social que não se interessava pelo desenvolvimento técnico e, até mesmo, pela vastidão amazônica que atuava como limitante a uma maior integração regional (WEINSTEIN, 1993).

Para Cleary (1993) o caráter colonial de organização das atividades econômicas submetidas à determinação dos mercados internacionais, que marcou a 
história do Brasil, teve como implicação a decadência de regiões cujo produto econômico não mais constituiu mercadoria relevante no comércio internacional ou que tiveram esgotadas suas fontes naturais.

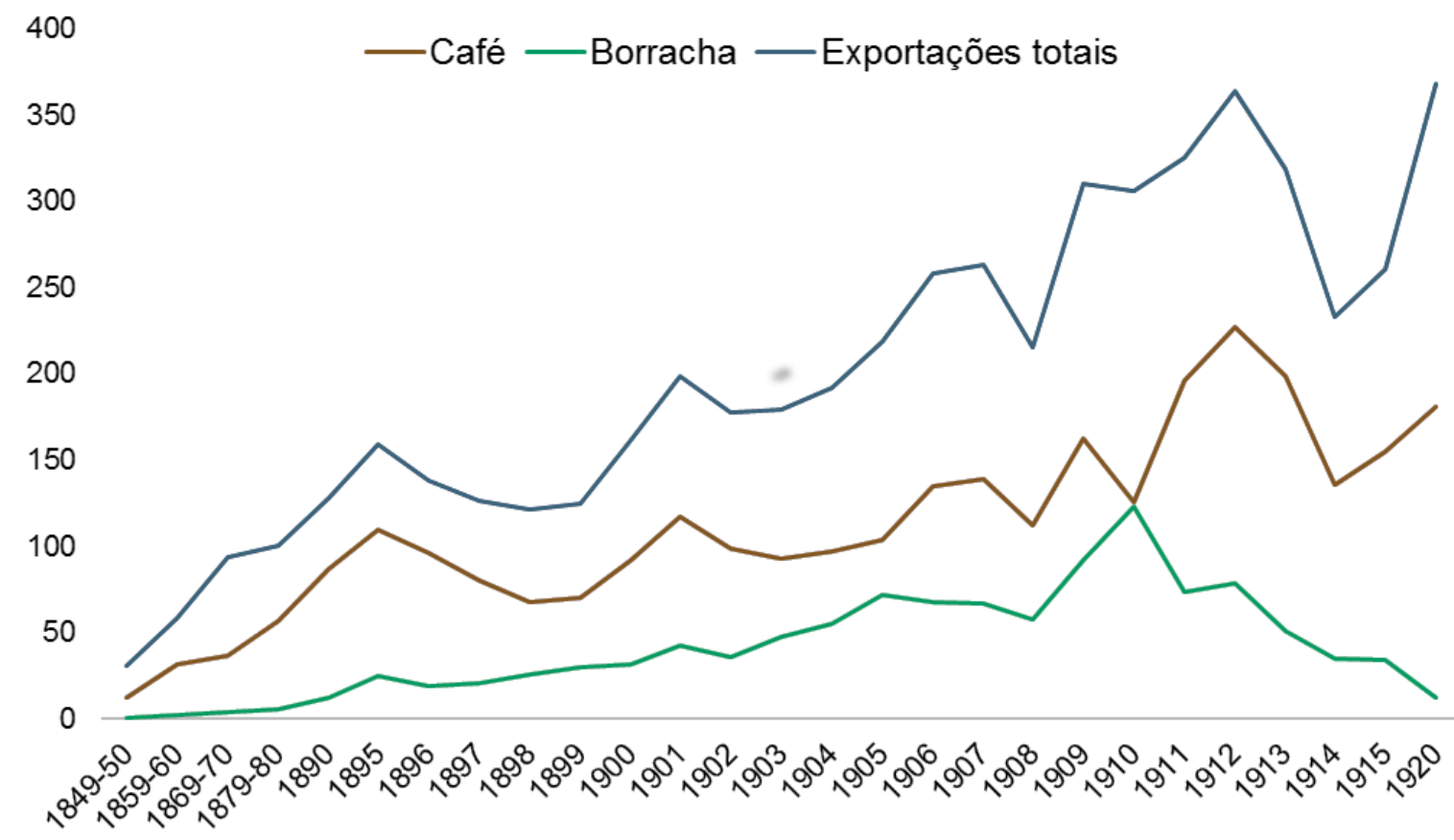

em milhares de dólares

Figura 6 - A borracha e o café nas exportações brasileiras: 1850 a 1920

Fonte: Adaptado de Santos (1980) com base no Anuário Estatístico do Brasil - 1939-1940 - Séries retrospectivas.

As relações de trabalho construídas ao redor da economia da borracha, como as condições exploratórias da mão de obra indígena e, depois, do migrante nordestino, em condições análogas à escravidão em uma economia baseada na relação de dependência entre o seringueiro e o dono do seringal (o seringalista), por sua vez dependente do aviador que intermediava a venda com a casa exportadora e, por fim, desta com o capital industrial na Europa Ocidental e nos Estados Unidos (SANTOS, 1980).

O sistema do aviamento impediu a formação de uma classe assalariada da borracha na Amazônia, pois toda a cadeia era baseada em crédito e a relação de mercado do seringueiro era restrita ao seringalista e ao regatão. Em contraste, a introdução do trabalhador assalariado nos cafezais paulistas, substituindo o trabalho escravo, permitiu a formação de um mercado consumidor e a consolidação de uma industrialização baseada nas indústrias de alimentos $e$ bens leves (WEINSTEIN, 1993). 
Para Furtado (2010) o seringueiro "não passava de um prisioneiro do sistema de aviamento, do comércio, do crédito, da violência privada do patrão. [...] na Amazônia a terra era farta e livre, ao mesmo tempo em que escasseava a mão de obra. O seringueiro não podia ser um trabalhador livre, um assalariado. Se fosse um trabalhador livre, de posse de seu salário, logo estaria em condições de seguir adiante".

Sobre a relação entre terra e trabalho, Martins (2010) afirma que "Onde o trabalho é livre, a terra não é. Se a terra é livre o trabalhador não poderá ser" e complementa "De fato, a terra sem trabalhadores nada representava e pouco valia em termos econômicos; enquanto isso, independentemente da terra, o trabalhador era um bem precioso". Isto marca a transição entre o fim do regime escravista e a Lei Imperial de Terras de 1850. Segundo Martins (2010, p. 31), com esta lei o rentismo é transferido da mão de obra servil ou escrava para a posse da terra, origem da situação fundiária do presente.

A Figura 7 apresenta um diagrama com o esquema de um seringal amazônico característico, por volta do ano 1900, com estradas em formas de alça e cabanas (Huts). Um seringueiro era responsável por uma ou duas "estradas" de seringueiras, nas quais trabalhava em dias alternados; a forma elíptica facilitava o retorno dele à cabana. A figura representa um seringal com área aproximada de $130 \mathrm{~km}^{2}$ e 3.573 seringueiras (WEINSTEIN, 1993) distribuídas em 32 estradas e três cabanas; Treze "estradas" partem da Cabana 1, empregando sete seringueiros; doze da Cabana 2, empregando seis seringueiros; e cinco da Cabana 3, empregando dois seringueiros. 


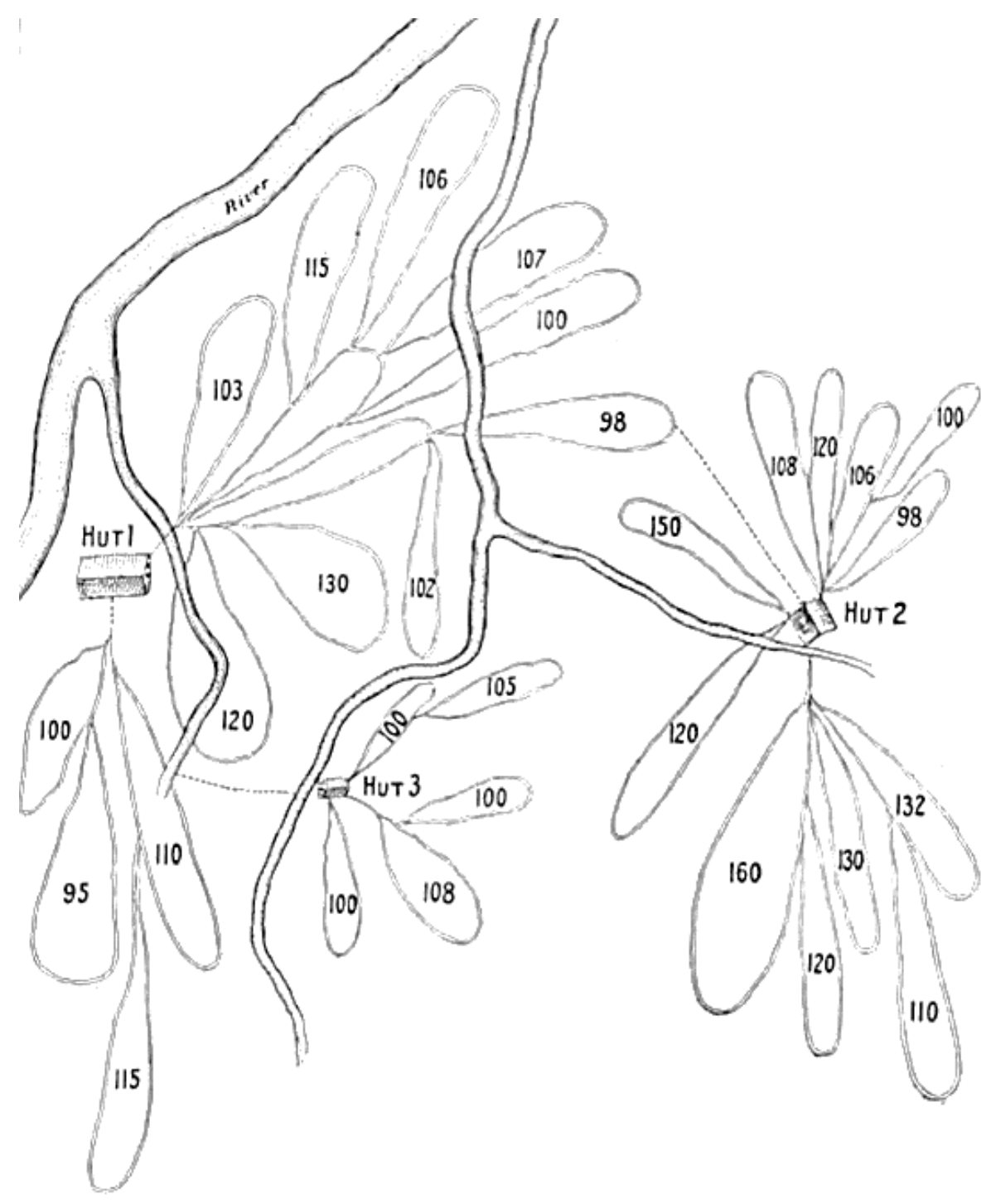

Figura 7 - Esquema de um seringal amazônico, por volta de 1900. Fonte: (INDIAN RUBBER WORLD, 1902, p.15).

O resgate da história econômica da exploração da borracha na Amazônia brasileira (e em todo o mundo tropical) permite a percepção de que esta atividade, fornecedora da indústria mais rica e poderosa de seu tempo, disseminou pobreza e atraso social por onde foi implantada, a começar pelo sistema de aviamento no caso brasileiro. Regimes de trabalho idênticos seriam implantados nas colônias britânicas no Sudeste Asiático (Malásia e Singapura), pela Michelin entre 1925 e 1965 em Dau Tieng (Vietnã) e em Harbel (Libéria), a partir de 1926 pela Firestone Natural Rubber Company, em funcionamento até hoje.

No entanto, nenhuma atrocidade é comparável ao trabalho escravo indígena no vale do rio Putumayo (Colômbia), durante o século XIX, pois os colonizadores 
acreditavam que deveriam disciplinar os "selvagens" com violência, conforme relatam Hardenburg (1912) e Taussig (1987), que sobre a exploração da borracha concluem:

3 A floresta e seus habitantes caíam sob o interesse dos negócios do Ocidente e dos ramos da ciência ocidental, sua geografia, sua antropologia e, claro, suas ciências industriais. Do Congo ao Putumayo, o que havia de mais antigo estava sendo dragado pelo moderno.

(TAUSSIG, 1987, p.93).

Em contraste, Fordlândia foi uma experiência singular, construída para atender o interesse americano de quebra do cartel inglês da borracha, mas também continha empenho e crença do próprio Henry Ford no trabalho e na irradiação do Americanismo além-fronteiras, em construir uma nova Dearborn na Amazônia (GRANDIN, 2010).

Instalada em 1929 às margens do rio Tapajós, Fordlândia foi uma concessão de 3 milhões de hectares que a Ford Motor Company obteve junto ao Governo do Estado do Pará em 1927, por intermédio de W.L. Reeves Blakeley e Jorge Dumont Villares, para exploração de todos os recursos contidos na área da concessão incluindo a produção de borracha. A escolha deste sítio teve como razão principal a proximidade da comunidade Boim, local que Henry Wickham em 1876 retirou as 70 mil mudas de seringueira levadas ao Kew's Royal Botanic Gardens (GRANDIN, 2010; JACKSON, 2008).

A escolha do sítio foi infeliz, pois ignorou a declividade do terreno onde o projeto Fordlândia foi implantado (Figura 8), e a sazonalidade do rio Tapajós que impedia a navegação de grande calado na estação seca. Estes fatores mais a inexperiência dos empregados da Ford Motor Company no manejo da seringueira e, também, a falta de experiência do cultivo em grande escala da seringueira em seu ambiente endêmico, levaram ao fracasso do projeto. Uma nova iniciativa foi realizada com a construção em 1938 de Belterra, um núcleo urbano a 80 quilômetros de Santarém, de topografia plana e recoberta por Terra Preta de Índio tendo à disposição um porto navegável durante o ano. Apesar de melhor sucedida, todo o projeto foi abandonado em 1945 pela Ford Motor Company (GRANDIN, 2010; JACKSON, 2008).

\footnotetext{
${ }^{3}$ Cf. HARDENBURG, W.E. The Devil's Paradise. Travels in the Peruvian Amazon: Region and Account of the Atrocities Committed upon the Indians Therein. Londres: T.Fisher Unwin, 1912.
} 


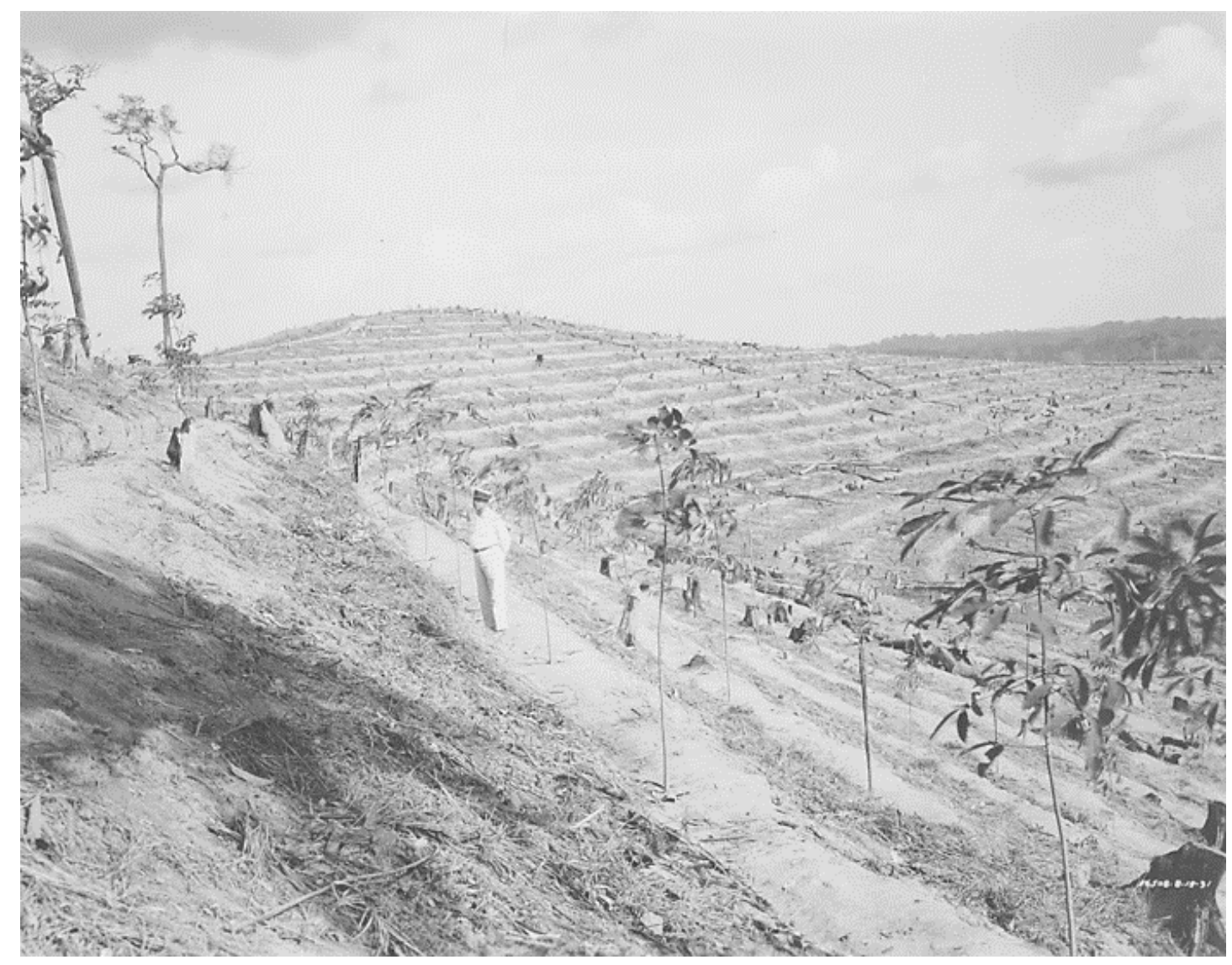

Figura 8 - Fordlândia: Plantio de seringueiras em colina desmatada

Fonte: Arquivo de imagens antigas - Fordlândia e Belterra (MUZELI, 2011).

Os projetos liderados pela Ford Motor Company em Fordlândia e em Belterra (em 1929 e em 1934, respectivamente), foram os primeiros grandes empreendimentos na região de Santarém que introduziram novas atividades e padrões de vida numa área até então pouco habitada (VALBUENA, 2008). Como registro daquele tempo restaram as edificações das duas cidades e a FLONA Tapajós (criada em 1974).

Em Belterra foram plantados aproximadamente 6,5 mil hectares de seringueiras entre 1934 e 1945. Após o encerramento das atividades da Ford Motor Company na região, as seringueiras continuaram em Belterra por mais 45 anos como é possível verificar na Figura 9, que mostra a rápida substituição delas pela agricultura anual e pela expansão da cidade de Belterra, e algumas poucas parcelas de floresta secundária. 


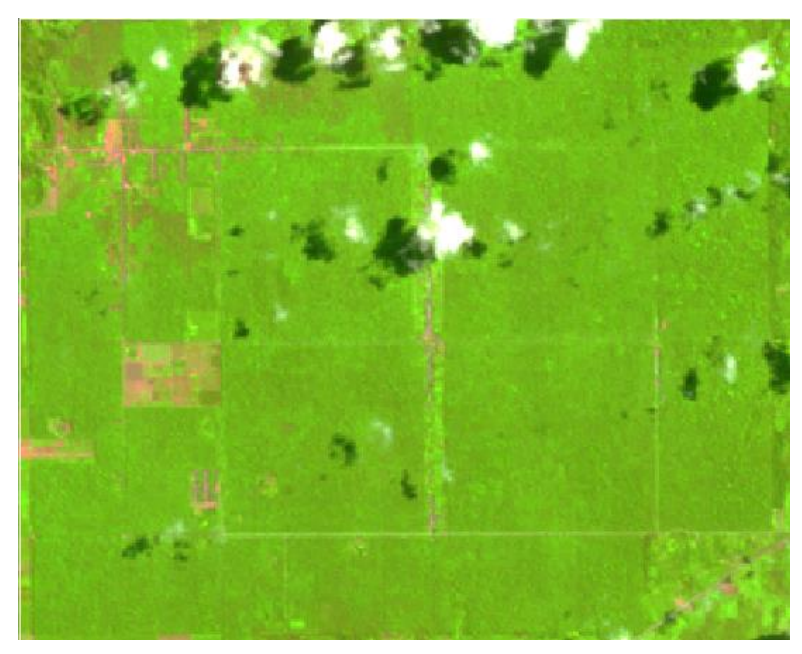

Belterra em 24/08/1984

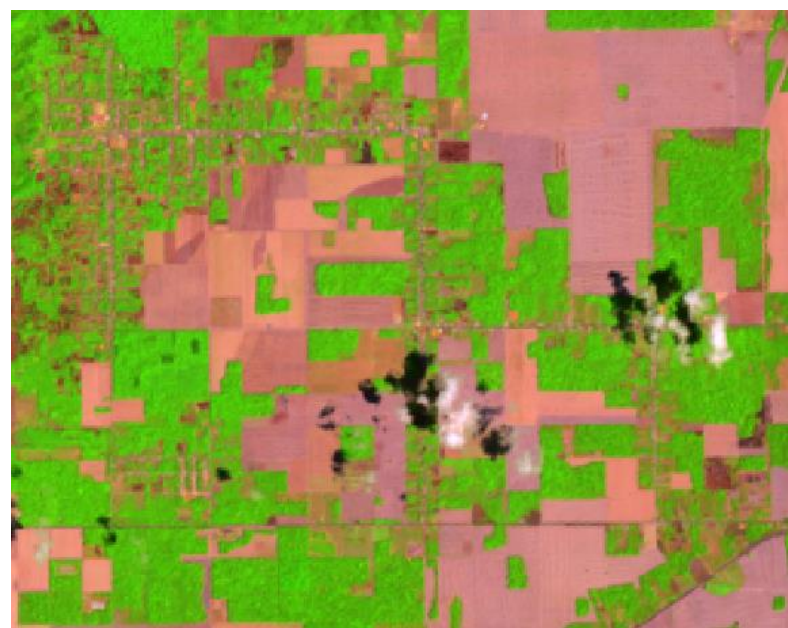

Belterra em 30/10/2014

Figura 9 - Área de cultivo de seringueiras em Belterra pela Ford Motor Co.

Fonte: LANDSAT-5 (1984) e LANDSAT-8 (2014). EARTHEXPLORER (USGS, 2016).

O fim da economia da borracha trouxe um vácuo e criou um excedente de mão de obra liberada dos seringais, aproveitando-se do sistema de aviamento já estruturado, que seria rompido somente na década de 1960 com a democratização do crédito rural (HOMMA, 1995). Enquanto na várzea amazônica ganhava impulso o cultivo da juta (Corchorus capsularis - Tiliaceae). Na região do Planalto de Santarém constituía-se um campesino composto pelos migrantes nordestinos que vieram originalmente trabalhar na economia da borracha, ou simplesmente refugiavam-se da seca em suas terras de origem.

A juta foi introduzida na várzea amazônica após o declínio da extração de cacau, com a destruição de cacaueiros na grande enchente de 1855, tendo como primeiro grande impulso a demanda nacional para o ensacamento do café e, após 1945, com a interrupção do mercado indiano de juta (WINKLERPRIS, 2006). Assim como a exploração da borracha, o cultivo da juta provocou grandes transformações nos cenário econômico, social, e político da região e foi também influenciada, de maneira endógena e exógena, fora do controle do produtor (HOMMA, 1995).

O Planalto de Santarém é uma região sem limites claramente definidos, mas está contido na área de estudo deste trabalho, pois exclui a várzea do rio Amazonas e o sítio urbano de Santarém e do povoado de Alter do Chão. Compreende, portanto, as colinas e platôs drenados pela bacia hidrográfica do rio Curuá-Una. Há poucas referências bibliográficas sobre a formação das comunidades e povoados do Planalto de Santarém e, mais precisamente da data de sua constituição, que de forma 
generalizada ocorreu através dos migrantes nordestinos que chegaram em Santarém durante a exploração da borracha, para trabalho nos seringais ou refugiados da seca.

Dentre estas comunidades e povoados destaca-se Mojuí dos Campos, emancipada de Santarém em 2013, município com 5 mil km² (Tabela 2 ) e população de 15.548 pessoas, conforme as estimativas do IBGE (2016). Marcadamente agrícola, o município de Mojuí dos Campos possui uma estrutura fundiária composta, hoje, por assentamentos e propriedades rurais pequenas e médias, onde se revezam a produção agrícola de hortifrúti para consumo local, a pecuária e a agricultura anual (soja, milho, arroz).

\subsection{DINÂMICA RECENTE DO USO E COBERTURA DA TERRA}

O declínio da economia da borracha levou à rearticulação das forças produtivas em quadros novos ou outras formas de organização social e técnica das relações de produção. Formou-se uma sociedade de sitiantes, com suas roças, criações e atividades econômicas para o autoconsumo (IANNI, 1978). Este foi o quadro que o autor resumiu para sua área de estudo em Conceição do Araguaia, válido para toda a Amazônia brasileira entre as décadas de 1940 e 1960; logo este quadro seria alterado.

Até a década de 1940 não houve um povoamento na Amazônia similar ao dos pioneiros nas fronteiras de expansão americana. De modo geral a terra era apropriada se houvesse algum produto natural que pudesse ser comercializado e, então, o povoamento ocorria efêmero, pois tão logo se esgotava este ciclo extrativista muitos emigravam e os demais aguardavam o próximo ciclo mercantil (CARDOSO; MULLER, 1978).

A região Amazônica era retratada como um imenso vazio demográfico, tal como registrado em mapas antigos do IBGE que destacavam atividades econômicas e assentamentos humanos nas calhas dos principais rios e principalmente ao longo do eixo Manaus - Belém. O valor histórico destes mapas hoje está em representar que essas zonas eram o alcance da colonização de origem europeia, enquanto atividades predecessoras como a borracha e a presença indígena histórica, eram simplesmente ignoradas.

Segundo Moran (1975), a integração da região Amazônica ao restante do país tinha profundas raízes em sonhos nacionalistas de intelectuais e políticos brasileiros, 
e torna-se explicita na década de 1940 com a "marcha para o oeste" de Getúlio Vargas como exemplifica suas palavras no Discurso do Rio Amazonas:

[...] sois a terra do futuro, o vale da promissão na vida do Brasil de amanhã.

(VARGAS,1942 p 260)

A ocupação do chamado hinterland ${ }^{4}$ Amazônico era uma preocupação de Estado, independente se o governo era civil ou militar (VALBUENA, 2008), para integrar a economia da região ao restante do país e garantir a soberania do território. Neste ponto Cleary (1998) é particularmente duro ao afirmar que a paranoia sobre o perigo das intenções estrangeiras é a única característica fixa da história amazônica, desde o século $\mathrm{XVI}$ até o presente.

Becker (2005) considera esta preocupação com a soberania da Amazônia não uma paranoia, mas uma questão geopolítica, de fundamental importância no povoamento da região desde a colonização, quando a coroa portuguesa (sem recursos) conseguiu expandir seus domínios territoriais além dos limites acordados no Tratado de Tordesilhas.

A primeira ação governamental de estímulo ao desenvolvimento econômico regional foi a criação da Superintendência do Plano de Valorização da Amazônia (SPVEA) em 1953. Dedicada ao fomento da produção da borracha e da atividade agrícola, teve suas funções e alcance ampliados com a sua extinção e a criação, em 1966, da Superintendência de Desenvolvimento da Amazônia (SUDAM). Com a criação da SUDAM surge também o conceito de Amazônia Legal - as unidades da federação beneficiadas pelas ações de fomento ao desenvolvimento da Amazônia.

A construção de Brasília (entre 1955 e 1960) e da rodovia BR-010 (BelémBrasília), em 1956, incentiva a ocupação das terras do Planalto Central e da Amazônia brasileira. O lançamento do Plano de Integração Nacional (PIN) em 1970 esboçava uma rede de estradas latitudinais e longitudinais que ligam a Amazônia ao Sul e ao Nordeste, atraindo flagelados da seca e o campesinato que buscava por terras mais baratas e acessíveis (CARDOSO; MULLER, 1978).

Dentre estas estradas destacam-se a BR-163 (Cuiabá-Santarém) e a BR-230 (Transamazônica), usadas como via de penetração para ocupação de terras dos

\footnotetext{
${ }^{4}$ Hinterland: vazio demográfico dependente (político e economicamente) de outro território como a capital de um país, ou mesmo um outro país.
} 
programas de colonização ou para grilagem. Era o processo de ocupação das áreas dos interflúvios até então inexplorados pelo homem "civilizado", mas habitado por dezenas de nações indígenas (VALBUENA, 2008). A estratégia do PIN foi complementada pela implantação de usinas hidrelétricas e por projetos de exploração de recursos naturais, que facilitaram a chegada de homens e do grande capital.

A Amazônia brasileira constituíra uma nova fronteira de ocupação e uma alternativa ao campesinato expulso das áreas agrícolas mais antigas, mas também uma grande fronteira global para a entrada do grande capital nacional e internacional para levar a cabo a exploração dos recursos naturais, proporcionando mão de obra e energia barata, assegurando a "presença do Brasil na exploração dos recursos da Amazônia sul-americana” (BECKER, 1990, 2005).

Kohlhepp (2002) divide as medidas de estímulo ao desenvolvimento econômico regional da Amazônia em duas categorias:

1) A ação estatal para o desenvolvimento da infraestrutura, concentrada no transporte rodoviário, como parte central dos esforços para a integração da Amazônia como, por exemplo, projetos de colonização rural. A redução de impostos para corporações foi um dos fatores mais importantes para atrair investidores privados aos projetos de desenvolvimento aprovados pelo Estado;

2) A ação privada baseada em investimentos em todos os setores econômicos mediante incentivos fiscais e a redução de taxas tributárias, empregados como capital de investimento, principalmente na criação de gado, indústria e projetos de mineração.

A região de Santarém é marcada durante este período pela construção da UHE Curuá-Una em 1977, da rodovia BR-230 e da rodovia BR-163. A construção destas novas estradas na Amazônia Central interligou áreas antes sem ligação alguma e deram bases à criação de novos corredores de exportação (Figura 10). Nas palavras de Delfim Netto:

[...] todos os recursos minerais e naturais da Amazônia terão uma saída natural pelo sistema hidro rodoviário, formado pelas estradas Cuiabá-Santarém e Transamazônica, em conexão com as vias navegáveis da região.

(NETTO, 1970). 


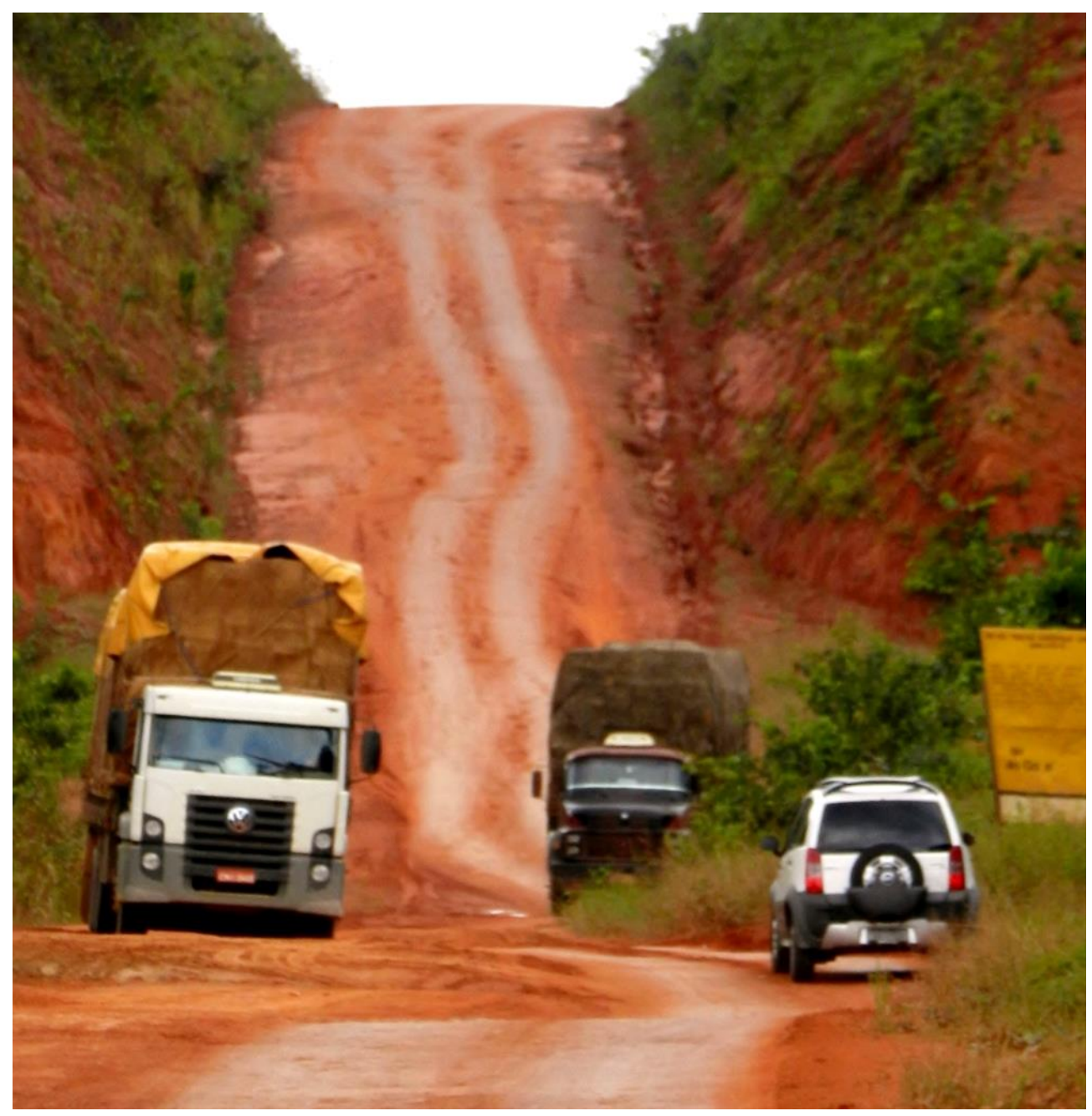

Figura 10 - Trecho não pavimentado da BR-163, em Belterra

Fonte: foto do autor, maio de 2012.

Pequenos colonos incentivados pelo Estado e grupos de médios e grandes latifundiários e madeireiros ocuparam progressivamente as margens das estradas abertas, alterando paisagens e introduzindo novas atividades que, em curto período de tempo, deram lugar a novas formas e estruturas na região (VALBUENA, 2008). Três tipos de colonização coexistem no período: a colonização planejada pelo Estado, aquela promovida por empresas privadas e a espontânea (ou "cada um por si"), materializada na grilagem de terras devolutas.

Como exemplo da colonização planejada pelo Estado, um esquema modular de comunidades é implantado ao longo da BR-230, distanciadas de modo que servissem de apoio aos novos fazendeiros, as agrovilas, agrópolis e rurópolis. Enquanto as agrovilas abrigariam 48 a 60 famílias, as agrópolis eram assentamentos maiores com 300 famílias e alguma estrutura comercial e administrativa, as rurópolis serviriam outras agrópolis dentro de seu raio de influência (MORAN, 1975). Deste 
plano surgiram cidades ao longo da BR-230 como Rurópolis, Placas, Uruará e Medicilândia.

$\mathrm{Na}$ região de Santarém destaca-se a formação de projetos de assentamento rural na BR-163 como o PA Moju I e II e, ao longo da rodovia PA-370 (Santarém Curuá-Una) outros assentamentos como o PA Corta-Corda e o PA Bom Sucesso. No entanto a criação destes assentamentos seguiu o modo de operação mais recorrente do governo federal: a delimitação e destinação das áreas pelo INCRA, sem infraestrutura de acesso e sem assistência técnica para os assentados.

A colonização estimulada levou ao aparecimento de padrões de ocupação em formato retangular e no padrão espinha de peixe, organizados em ambos os lados de uma artéria principal, como exemplifica a Figura 11. Se os agricultores chegaram antes dos madeireiros, o padrão de ocupação se organiza como uma espinha de peixe (ou de forma retangular) em função do padrão de prosperidade da população agrícola pioneira (pequenos versus grandes proprietários). Se os madeireiros chegaram antes da agricultura, então o padrão de ocupação é dendrítico (ARIMA et al., 2015).
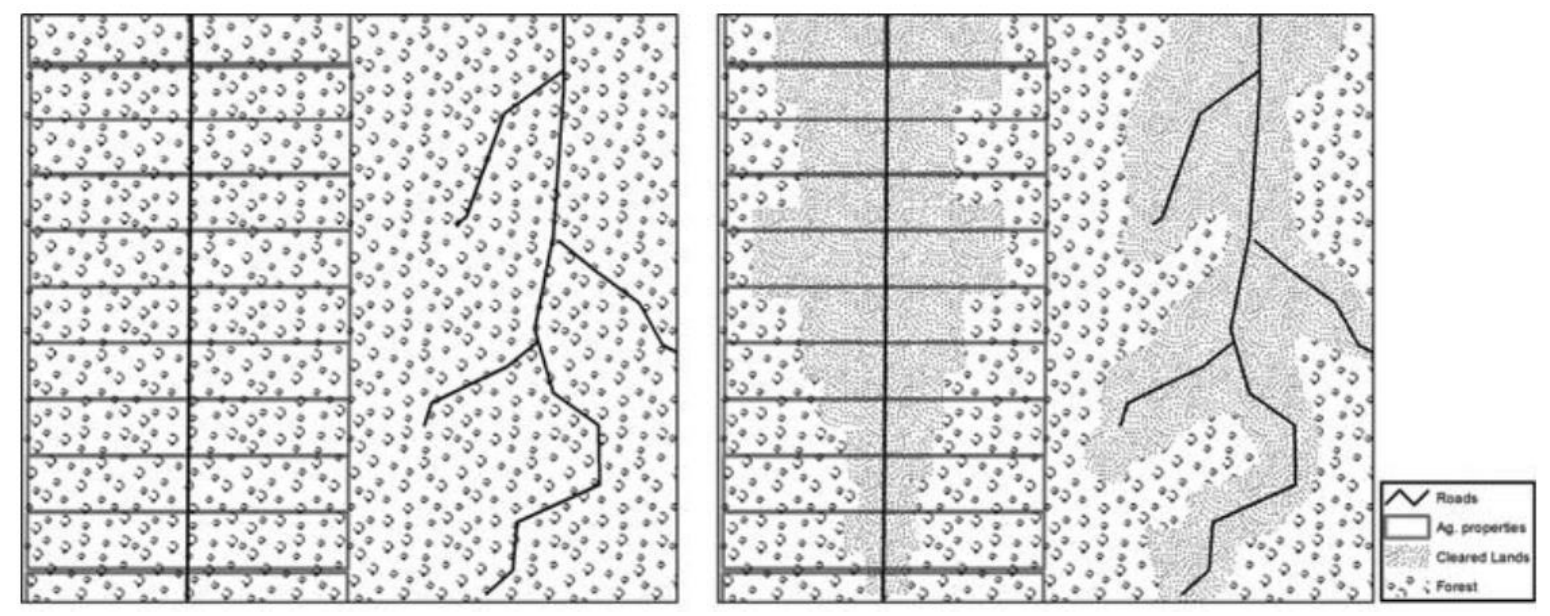

Na esquerda, a abertura de estradas e, à direita, o desmatamento.

Figura 11 - Modelo dos padrões de ocupação espinha de peixe e dendrítico Fonte: Arima et al. (2015).

Quando o Estado não é presente o padrão de ocupação e fragmentação florestal segue outra lógica, atendendo um interesse específico. Deste modo, a abertura de estradas para exploração ilegal de madeira segue um padrão dendrítico, semelhante ao Mahogany (ARIMA et al., 2015), diferente do manejo florestal que opera pelo parcelamento da floresta em áreas geometricamente definidas. $\mathrm{Na}$ área de 
estudo coexistem os dois padrões de exploração madeireira, no interflúvio entre os rios Curuá-Una e Curuatinga.

Semelhante ao padrão dendrítico, os autores identificam uma variação desse padrão chamado caule-de-rosa (associado à atividade garimpeira) e o padrão radial (associado a grilagem de terras a partir de um núcleo urbano ou localidade numa via arterial). Ambos os padrões não ocorrem na região de Santarém, mas são recorrentes ao redor da BR-163 e da BR-230 no sudoeste do Estado e também em São Félix do Xingu, regiões onde o Estado foi menos presente e a prática do "cada um por si" foi disseminada.

A modernização levou ao esvaziamento populacional do campo, através da ocupação da terra por médios e grandes latifundiários (representantes das técnicas da chamada "revolução verde"), e da concessão de crédito para modernização de pequenos e médios agricultores. Os campesinos não conseguem suportar a pressão pela compra de suas terras e emigram para Santarém e Manaus (ou ainda as outras cidades da margem esquerda do rio Amazonas) ou avançam para áreas de floresta em projetos de colonização e reforma agrária do INCRA, incorporando novas áreas a este processo (VALBUENA, 2008).

Este fenômeno não foi restrito apenas à Santarém e à Amazônia brasileira. $A$ demanda global por produtos agrícolas como alimentos, rações e combustíveis é, na contemporaneidade, o principal motor da expansão agrícola e pecuária no mundo em desenvolvimento. No mundo tropical entre 1980 e 2000, 55\% das novas terras agrícolas vieram à custa de florestas intactas, e outros $28 \%$ vieram de florestas perturbadas [secundárias] (GIBBS, 2010).

Os estímulos à ocupação da Amazônia, a estabilização monetária e fiscal implantada nos anos 1990, a chegada do capital externo e o emprego das técnicas de mecanização verde levaram o Brasil à liderança global na produção de mercadorias como grãos, carne e minério de ferro, trazendo importantes divisas ao país. As macrorregiões da Amazônia (BECKER, 2005) são fundamentais neste processo; a Amazônia Meridional (ou Arco de Fogo) e a Amazônia Central (onde se situa Santarém) abrigaram a expansão agropecuária e a exploração mineral à custa do desmatamento (Figura 12), enquanto o desenvolvimento econômico da macrorregião da Amazônia Ocidental foi polarizado pelas indústrias da Zona Franca de Manaus e o abandono das áreas periféricas. 


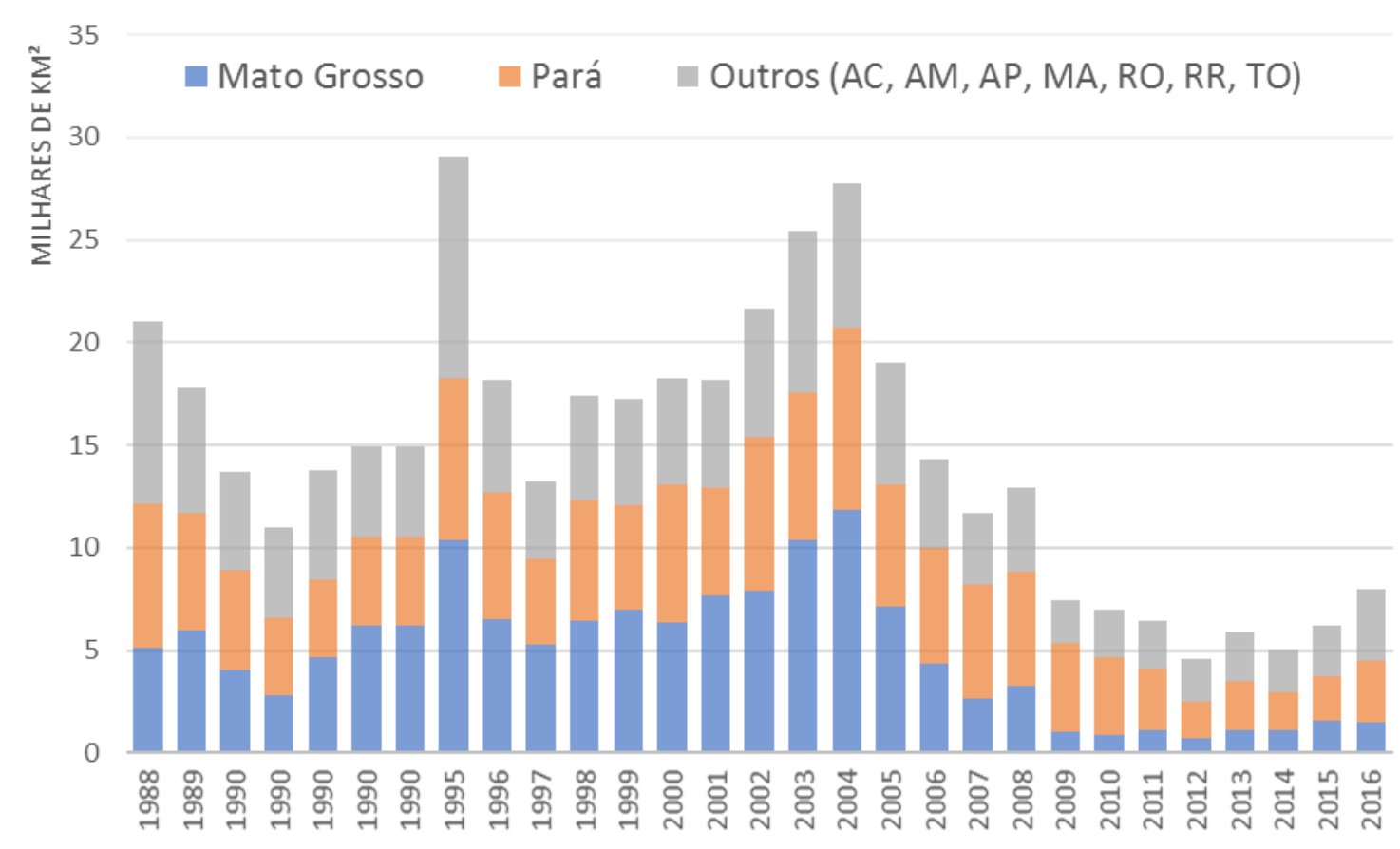

Figura 12 - Desmatamento nos Estados da Amazônia Legal

Fonte Adaptado de PRODES (INPE, 2016).

Segundos os dados do PRODES (INPE, 2016), $421.871 \mathrm{~km}^{2}$ de floresta foram perdidos, sem considerar floresta secundária, floresta de várzea e savana. Deste total, $143.159 \mathrm{~km}^{2}$ foram perdidos no Estado do Pará e $141.425 \mathrm{~km}^{2}$ foram perdidos no Estado do Mato Grosso, portanto os dois Estados que mais contribuíram (33\% cada um) ao desmatamento da Amazônia no Brasil. Consideramos o Estado de Mato Grosso apenas para efeito comparativo.

Os dados do PRODES refletem dois comportamentos distintos ao longo de 28 anos de monitoramento da Amazônia pelo INPE. Primeiro, o incremento das taxas de desmatamento com dois picos históricos, com 29.059 km² (7.845km² no Pará) em 1995 e 27.772 km² (8.870 km² no Pará) em 2004, refletindo as ações de estímulo à ocupação da região do período militar, o início dos conflitos fundiários e mortes no campo, as flutuações econômicas do país até a estabilização monetária a partir de 1994 e o estabelecimento da agropecuária de alta produtividade a partir de 1995.

As pressões externas e internas sobre o governo brasileiro levaram a uma mudança paulatina de política pública através da criação de unidades de conservação e terras indígenas e ações tímidas de comando e controle. O ponto de mudança foi a criação do PPCDAM em 2003, com a abertura dos dados PRODES e DETER para toda a sociedade e o incremento na criação de áreas protegidas e intensificação da fiscalização. Na esfera governamental destaca-se ainda o ZEE como instrumento de 
gestão e planejamento territorial e, graças à pressão de organizações não governamentais, os acordos setoriais, da Moratória da Soja em 2006 e do Termo de Ajuste de Conduta da Pecuária em 2009, levaram à redução do desmatamento em Santarém e em toda a Amazônia brasileira.

A Moratória da Soja da Amazônia brasileira foi o primeiro acordo de governança em uma cadeia de suprimentos nos trópicos (GIBBS, 2015). Neste acordo, as empresas representadas pela Associação Nacional dos Exportadores de Cereais (ANEC) e pela Associação Brasileira das Indústrias de Óleo Vegetal (ABIOVE), se comprometeram a não comercializar e financiar produtores de soja que desmataram em áreas localizadas no bioma Amazônia após julho de 2006, que plantaram soja em unidades de conservação ou terras indígenas ou, ainda, que constem na lista de trabalho escravo do Ministério do Trabalho e Emprego (MTE).

A experiência bem sucedida na cadeia da soja e os problemas semelhantes na cadeia da carne levaram ao Termo de Ajuste Conduta (TAC) da Pecuária, um acordo entre o Ministério Público Federal no Pará (MPF-PA) e quatro grandes frigoríficos que atuavam naquela época no Estado do Pará e se comprometeram, de forma análoga à Moratória da Soja, a não comercializar gado com criadores que tenham desmatado em suas propriedades a partir da assinatura do TAC, em outubro de 2009, e os demais critérios relacionados à criação de gado áreas de unidades de conservação e terras indígenas e ao trabalho escravo.

O fato disparador da Moratória da Soja foi a publicação do relatório Eating up the Amazon (GREENPEACE, 2006), que denunciou a expansão do cultivo da soja à custa do desmatamento em Mato Grosso (ao redor do Parque Indígena do Xingu) e em Santarém, no chamado Planalto de Santarém (área de estudo). O relatório apontou que o agente desencadeador deste processo foi a instalação do terminal portuário da Cargill em Santarém, além das expectativas que o anunciado asfaltamento da BR-163 trazia à região.

O TAC da Pecuária teve um histórico semelhante à Moratória da Soja. Outro relatório do Greenpeace intitulado "Farra do Boi na Amazônia" (GREENPEACE, 2009), denunciou como o suprimento de carne e de couro para a indústria de alimentos, indústria da moda e para redes varejistas, tinha na sua base a criação de gado em áreas ilegalmente ocupadas (grilagem), com histórico de desmatamento ilegal e, em alguns casos, empregando trabalhadores em condições análogas à escravidão. 
Duas ações efetivas levaram ao êxito dos compromissos setoriais, o monitoramento com base no perímetro das propriedades rurais e em sensoriamento remoto, e a restrição do crédito ao produtor/criador em desacordo com os critérios estabelecidos nos acordos (NEPSTAD et al., 2014). A Tabela 3 resume o cenário de governança construído a partir dos compromissos setoriais da carne e da soja.

\section{Tabela 3 - Fases de evolução de políticas públicas e iniciativas de cadeias de fornecimento para reduzir o desmatamento na Amazônia: 2000 a 2013}

\begin{tabular}{|c|c|c|}
\hline Expansão agroindustrial & Limite da governança & Performance territorial \\
\hline \multicolumn{3}{|c|}{ Contexto da agricultura, pecuária e infraestrutura } \\
\hline Expansão da soja e gado & $\longrightarrow$ Retração da soja e do gado & Expansão da soja e gado $\rightarrow$ \\
\hline Intensificação da pecuária & & \\
\hline Alta rentabilidade & Baixa rentabilidade & $\rightarrow$ Melhoria da rentabilidade $\rightarrow$ \\
\hline Anúncio da pavimentação de estradas & & $\rightarrow \quad \begin{array}{c}\text { Obras na BR-158, BR-163, } \\
\text { Interoceânica }\end{array}$ \\
\hline $\begin{array}{l}\text { Anúncio da construção de novas } \\
\text { hidrelétricas }\end{array}$ & & $\begin{array}{l}\text { Construção de novas hidrelétricas } \\
\text { (rio Xingu, rio Madeira, rio Tapajós) }\end{array}$ \\
\hline \multicolumn{3}{|c|}{ Governo } \\
\hline $\begin{array}{l}\text { Monitoramento baseado em } \\
\text { Sensoriamento Remoto }\end{array}$ & $\begin{array}{c}\rightarrow \quad \text { Monitoramento para apoiar } \\
\text { fiscalização }\end{array}$ & \\
\hline Áreas protegidas em áreas remotas - & $\begin{array}{c}\rightarrow \text { Novas áreas protegidas nas novas } \\
\text { fronteiras }\end{array}$ & $\rightarrow$ Áreas protegidas sob ameaça - \\
\hline $\begin{array}{l}\text { Código Florestal de } 1965 \\
\text { desrespeitado }\end{array}$ & Código Florestal de 1965 aplicado & $\rightarrow$ Novo Código Florestal (2012) - \\
\hline CAR (Mato Grosso e Pará) & $\longrightarrow$ & CAR exigido nacionalmente $\rightarrow$ \\
\hline Gestão ao nível da propriedade & $\longrightarrow$ & Gestão ao nível dos municípios $\longrightarrow$ \\
\hline \multirow[t]{2}{*}{$\begin{array}{l}\text { Crédito e incentivos fiscais para o } \\
\text { desmatamento }\end{array}$} & & $\begin{array}{c}\text { Fundo Amazônia, Programa de } \\
\text { Agricultura de Baixo-Carbono }\end{array} \rightarrow$ \\
\hline & & $\begin{array}{c}\text { Política de mudanças climáticas, } \\
\text { REDD+ }\end{array}$ \\
\hline \multicolumn{3}{|c|}{ Intervenções nas cadeias de fornecimento } \\
\hline & Moratória da Soja & Acordos da Pecuária $\longrightarrow$ \\
\hline \multirow[t]{2}{*}{ Empréstimos IFC e Traders $\longrightarrow$} & Monitoramento privado para coação & \\
\hline & & Certificação de commodities $\rightarrow$ \\
\hline
\end{tabular}

Fonte: Adaptado de Nepstad et al. (2014).

Ao analisar os dados de desmatamento para a área de estudo conforme o município (Tabela 4) verifica-se que 339.124 hectares $(96,5 \%)$ do desmatamento acumulado ocorreram nos municípios de Belterra, Mojuí dos Campos e Santarém, e apenas 12.287 hectares $(3,5 \%)$ ocorreram em Prainha e Uruará. Cabe lembrar que a emancipação de Mojuí dos Campos ocorreu apenas em 2013, assim todo o histórico 
de ocupação deste município ocorreu tendo Santarém como sede administrativa e econômica deste território.

Tabela 4 - Desmatamento na área de estudo conforme o município

\begin{tabular}{|c|c|c|c|c|c|c|}
\hline $\begin{array}{c}\text { Ano / } \\
\text { município }\end{array}$ & Belterra & $\begin{array}{l}\text { Mojuí dos } \\
\text { Campos }\end{array}$ & Prainha & Santarém & Uruará & Total \\
\hline $1997^{1}$ & 47.993 & 106.534 & 5.058 & 73.222 & 862 & 233.670 \\
\hline 2000 & 6.596 & 14.464 & 0 & 4.092 & 61 & 25.213 \\
\hline 2001 & 2.776 & 5.334 & 339 & 9.904 & 58 & 18.410 \\
\hline 2002 & 1.721 & 3.719 & 177 & 4.173 & 14 & 9.804 \\
\hline 2003 & 2.427 & 5.468 & 65 & 3.248 & 201 & 11.409 \\
\hline 2004 & 2.763 & 6.135 & 91 & 2.329 & 477 & 11.794 \\
\hline 2005 & 341 & 1.420 & 58 & 576 & 1.004 & 3.398 \\
\hline 2006 & 855 & 5.717 & 161 & 3.113 & 1.082 & 10.929 \\
\hline 2007 & 999 & 3.427 & 82 & 879 & 958 & 6.345 \\
\hline 2008 & 426 & 2.567 & 38 & 1.685 & 248 & 4.964 \\
\hline 2009 & 581 & 3.090 & 107 & 1.207 & 441 & 5.426 \\
\hline 2010 & 468 & 1.699 & 53 & 1.332 & 151 & 3.703 \\
\hline 2011 & 152 & 1.162 & 50 & 540 & 169 & 2.073 \\
\hline 2012 & 223 & 1.155 & 19 & 697 & 138 & 2.233 \\
\hline 2013 & 88 & 411 & 2 & 453 & 122 & 1.076 \\
\hline 2014 & 116 & 618 & 0 & 229 & 0 & 963 \\
\hline $2015^{2}$ & 1.089 & 3.196 & 69 & 1.868 & 446 & 6.667 \\
\hline $2016^{3}$ & 467 & 1.030 & 0 & 562 & 358 & 2.418 \\
\hline Total & 70.080 & 167.144 & 6.370 & 110.111 & 6.790 & 360.495 \\
\hline
\end{tabular}

Fonte: Adaptado de PRODES (INPE, 2016).

Considerando os $11.124 \mathrm{~km}^{2}$ da área total em estudo, $3.605 \mathrm{~km}^{2}(32,4 \%)$ foram desmatados, dos quais $2.337 \mathrm{~km}^{2}$ desmatados até 1997 (64,8\%) e $1.268 \mathrm{~km}^{2}$ entre 2000 e 2016 (35,2\%), sugerindo duas leituras: que o desmatamento em 16 anos foi menor que o acumulado até 1997 e, que este período foi extremamente positivo pela redução considerável do desmatamento em toda a Amazônia (Figura 12) e na área de estudo (Figura 13) graças aos esforços combinados de políticas públicas e governança do setor privado. Mas também permite a leitura que em 16 anos foi desmatado o equivalente à metade de todas as florestas desmatadas nos anteriores 340 anos de colonização e consolidação do povoamento como pesquisado e informado ao longo deste capítulo.

No entanto, apesar da redução de $70 \%$ nas taxas de desmatamento para a Amazônia brasileira (NEPSTAD et al., 2014), e as taxas mínimas registradas entre 2013 e 2014, a partir de 2015 as taxas de desmatamento para a Amazônia subiram, 
e também para a área de estudo (Figura 13). Os fatores responsáveis não estão devidamente claros, mas pode-se atribuir como efeito da aprovação da Lei 12.651 (BRASIL, 2012), e a percepção de anistia para aquele que não respeitou a Lei 4.771 de 1965 (ver Capítulo 4).

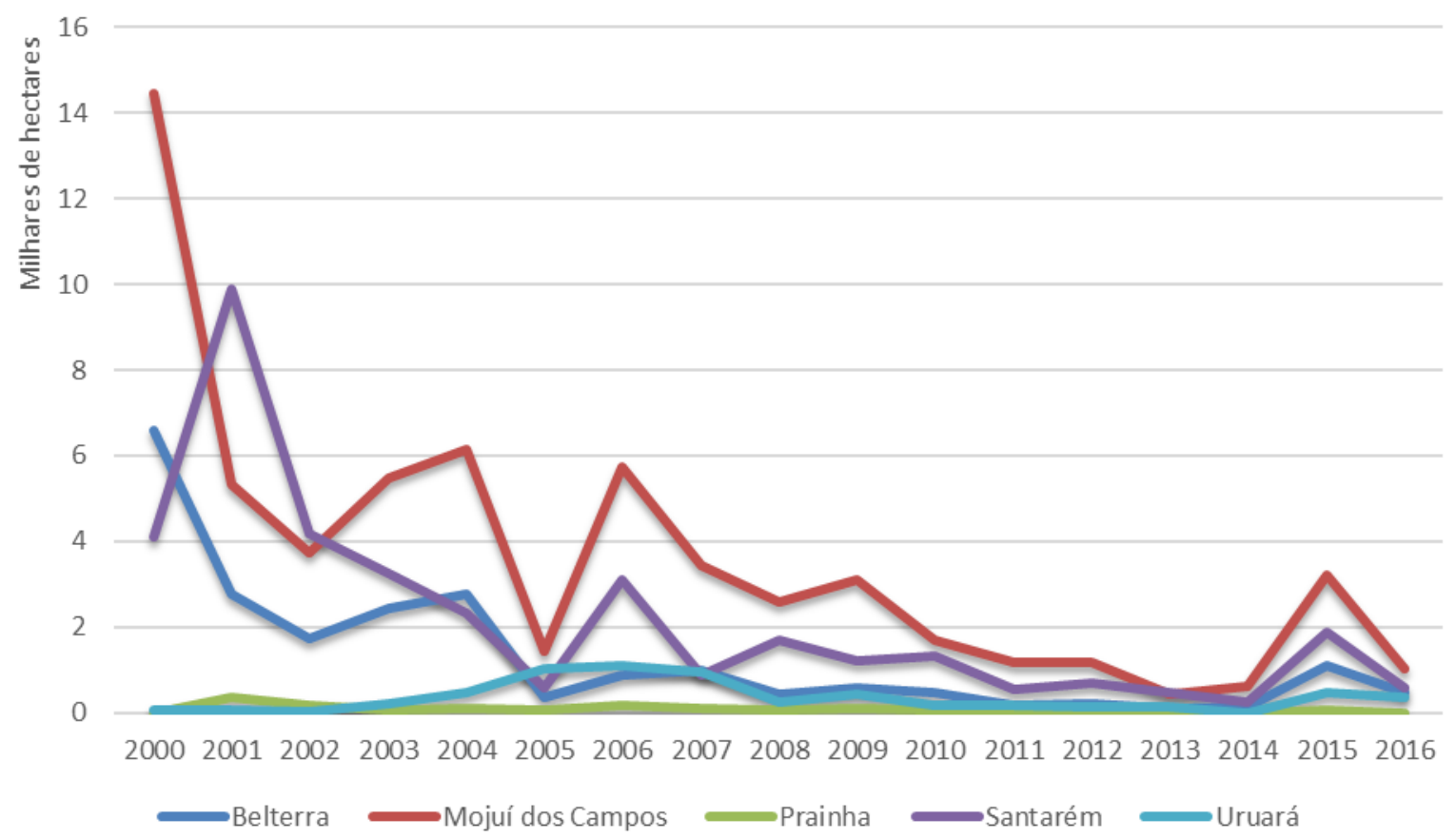

Figura 13 - Desmatamento na área de estudo conforme o município Fonte: Adaptado de PRODES (INPE, 2016).

Outros fatores de influência são aqueles relacionados a atividades ilegais como o roubo de madeira em floresta remanescente (como na área de estudo) e a proliferação de garimpos na Amazônia, ambas as atividades sem compromissos setoriais a exemplo da cadeia da carne e da soja, analisadas em estudos anteriores (NEPSTAD et al. 2014; GIBBS et al., 2015, entre outros) que argumentam o êxito destes acordos, mas não explicam os fatores responsáveis pelo desmatamento residual. Uma das evidências pode ser verificada no aumento do preço da terra e no volume de crédito para atividades agrícolas e pecuárias, que crescem em razão inversa à redução das taxas de desmatamento para o Estado do Pará, como mostra a Figura 14. 


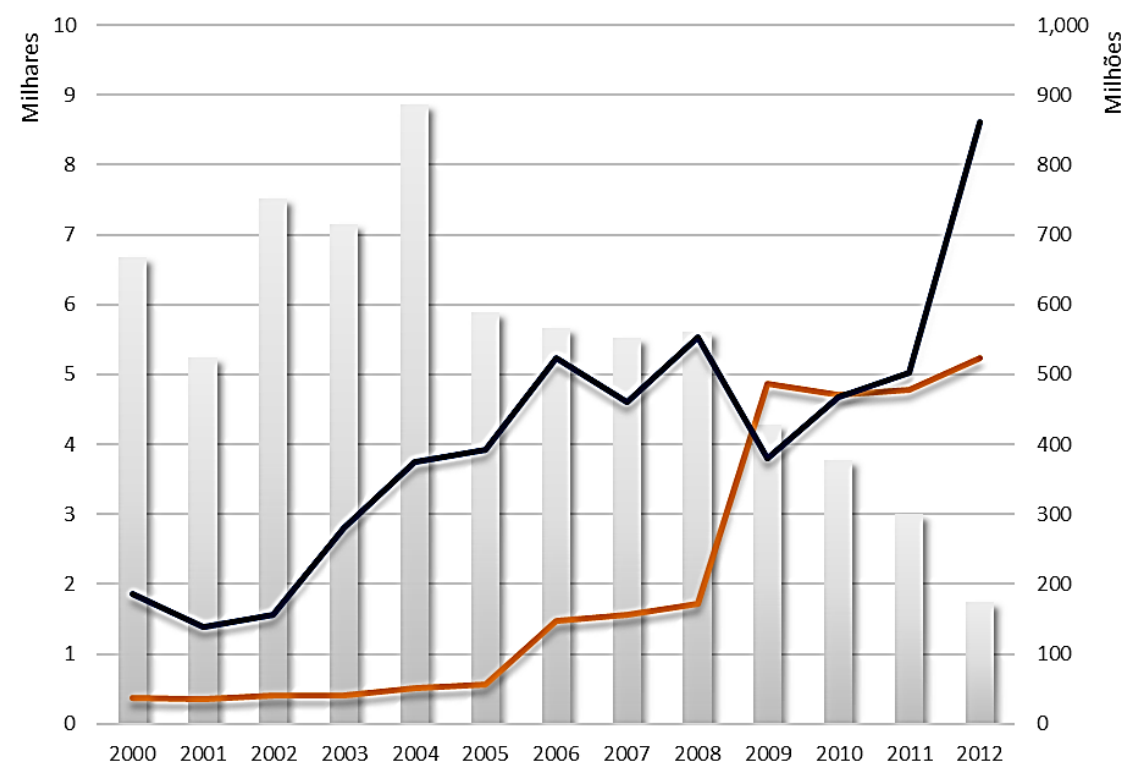

A)

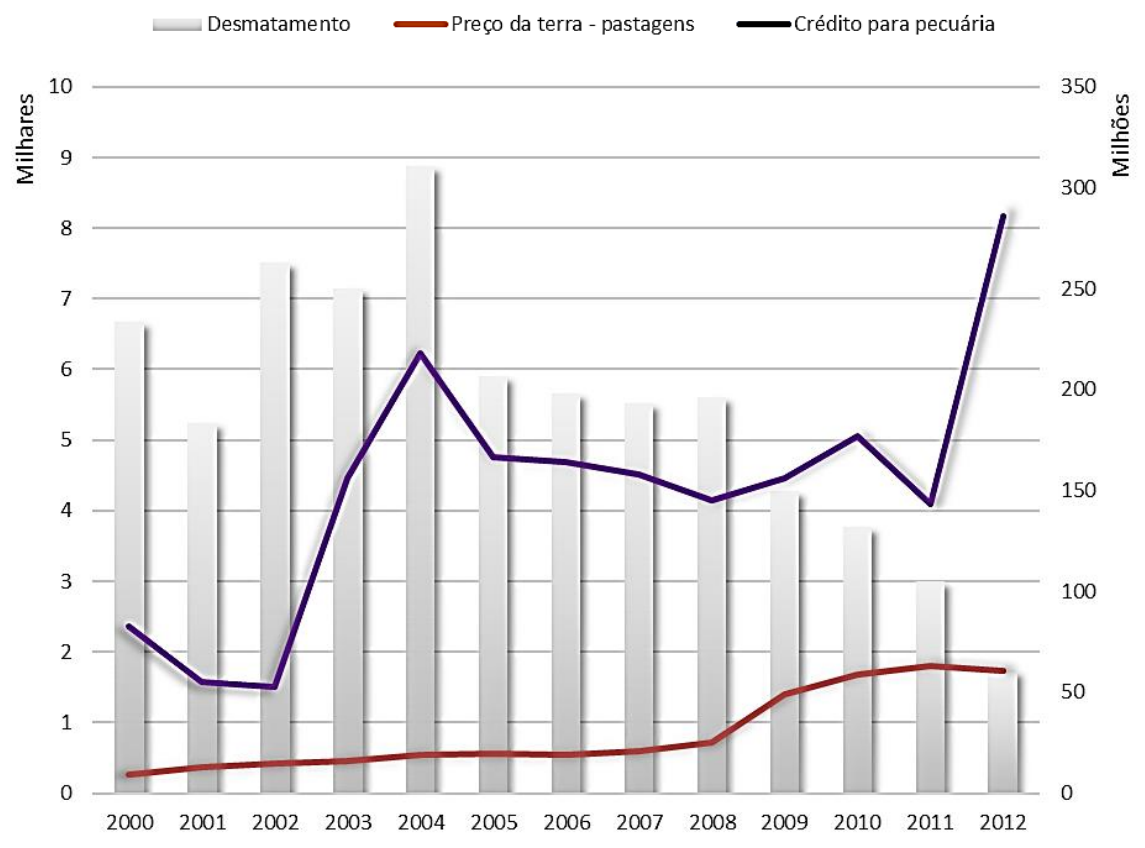

B)

Desmatamento —Preço da terra - lavouras Crédito agrícola

Figura 14 - Desmatamento, preço da terra e crédito rural no Estado do Pará

Desmatamento em milhares de $\mathrm{km}^{2}$; preço da terra em milhares de reais; crédito rural em milhões de reais.

Fonte: Adaptado de PRODES (INPE, 2016) Portal IBRE (FGV, 2016) e BACEN (2012).

Os dados de preço da terra do Portal IBRE (FGV, 2016) e do Anuário Estatístico do Crédito Rural (BACEN, 2012) combinados aos dados de desmatamento do PRODES (INPE, 2016) mostram a evolução do preço da terra e do crédito rural durante 12 anos. Enquanto até 2004 o crédito rural destinado à cooperativas e produtores rurais (não familiares) acompanhou o aumento do desmatamento, a partir de 2008 ocorre uma inflexão e o volume de crédito cresce substancialmente. Para o preço da terra ocorre processo semelhante: uma queda lenta e gradativa do preço da 
terra para agricultura e pecuária até 2004 e, a partir de 2008, a significativa elevação do preço da terra, especialmente das pastagens.

Dois fatores podem ser atribuídos à elevação do crédito e do preço da terra: o ciclo de valorização de mercadorias (commodities) durante toda a década de 2000 por conta do crescimento dos países em desenvolvimento, e a governança proporcionada pelos sucessos nas ações de combate ao desmatamento, seja o PPCDAM, seja a ação dos governos estaduais e o fortalecimento das estruturas municipais, seja os compromissos setoriais. O efeito combinado destas ações proporcionou a chegada do capital expansionista do agronegócio, que necessitou de regras para se realizar na Amazônia.

O mesmo agrupamento de forças entre ação estatal e ação privada que Kohlhepp (2002) identificou para o estímulo ao desenvolvimento econômico regional da Amazônia nas décadas de 1980 e 1990, passou a operar na década de 2000 para reduzir o desmatamento devido aos compromissos internacionais assumidos pelo Brasil, decorrentes da exposição da degradação florestal e social da Amazônia. 0 cumprimento destes compromissos foi condição necessária para a chegada do investimento privado no agronegócio.

As atividades ilegais (grilagem, roubo de madeira e garimpo) sempre estiveram presentes, mas a taxa atual de desmatamento tornou a contribuição delas mais evidente. Diferente da cadeia da soja e da carne, cada qual com somente três ou quatro empresas globais que dominam o respectivo mercado, as demais cadeias contam com múltiplos revendedores e a identificação das feições de degradação florestal é distinto pois não se resume ao mapeamento de corte raso, além do próprio interesse do criminoso em aderir a um compromisso setorial.

Em relação a área de estudo e a região de Santarém foi identificado o mesmo padrão daquele identificado para o Estado do Pará na Figura 14. No entanto, os indicadores de preços agrícolas do Portal IBRE (FGV, 2016) não compreendem municípios, apenas unidades da federação. Outra ressalva é a falta de dados sobre crédito rural para o município de Mojuí dos Campos, emancipado de Santarém em 2013, não considerado no Anuário Estatístico do Crédito Rural (BACEN, 2012).

Verifica-se na Figura 15 o predomínio do crédito rural agrícola frente ao crédito rural para pecuária em Santarém e Belterra e uma clara relação inversa entre a redução do desmatamento e o crescimento do volume de crédito a partir de 2006, e aumento no crédito para pecuária em Santarém em 2012. 


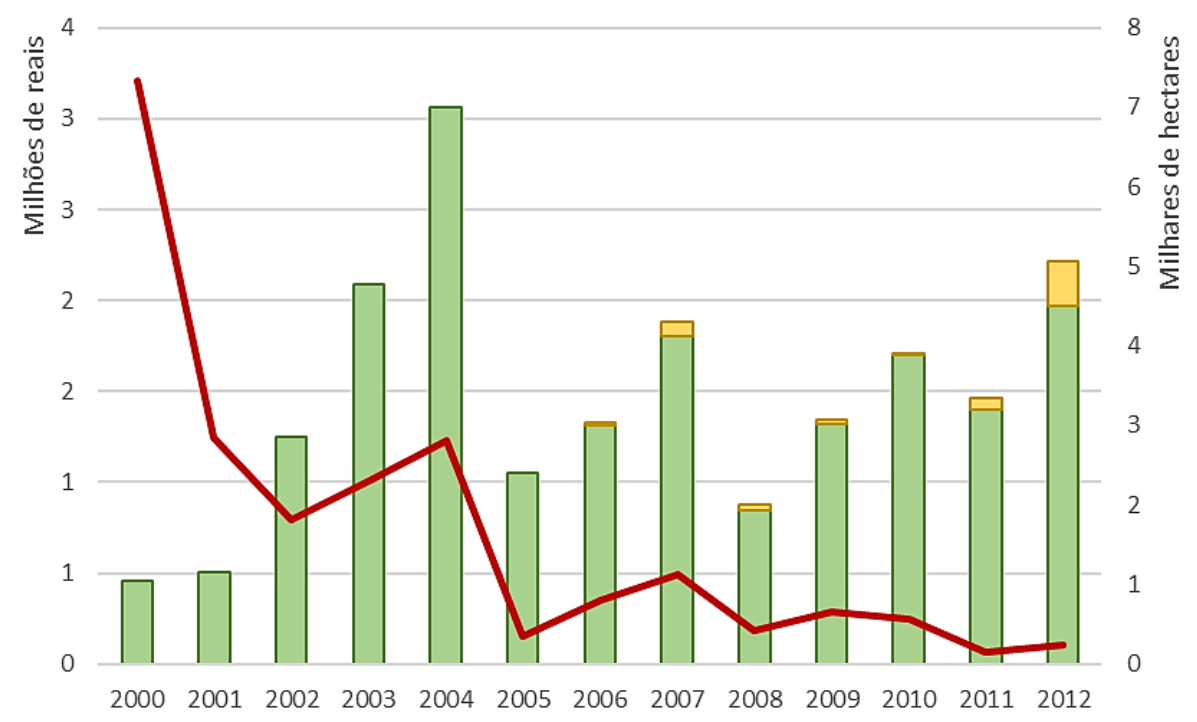

\section{Belterra}

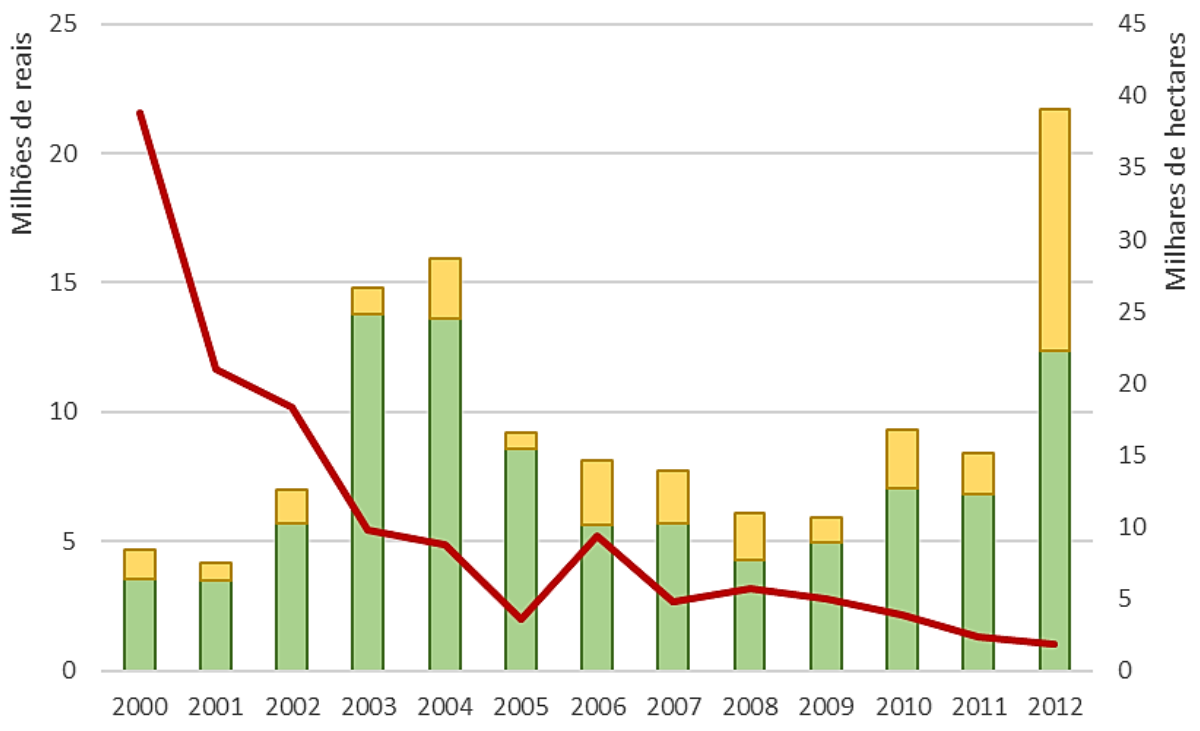

\section{Santarém}

Figura 15 - Crédito rural e desmatamento em Belterra e Santarém

Fonte: Adaptado de PRODES (INPE, 2016) e BACEN (2016).

Em Prainha e Uruará também não está clara a relação entre crédito rural e desmatamento, como é possível verificar na Figura 16. Nestes dois municípios o crédito para pecuária prevalece sobre o crédito agrícola. 


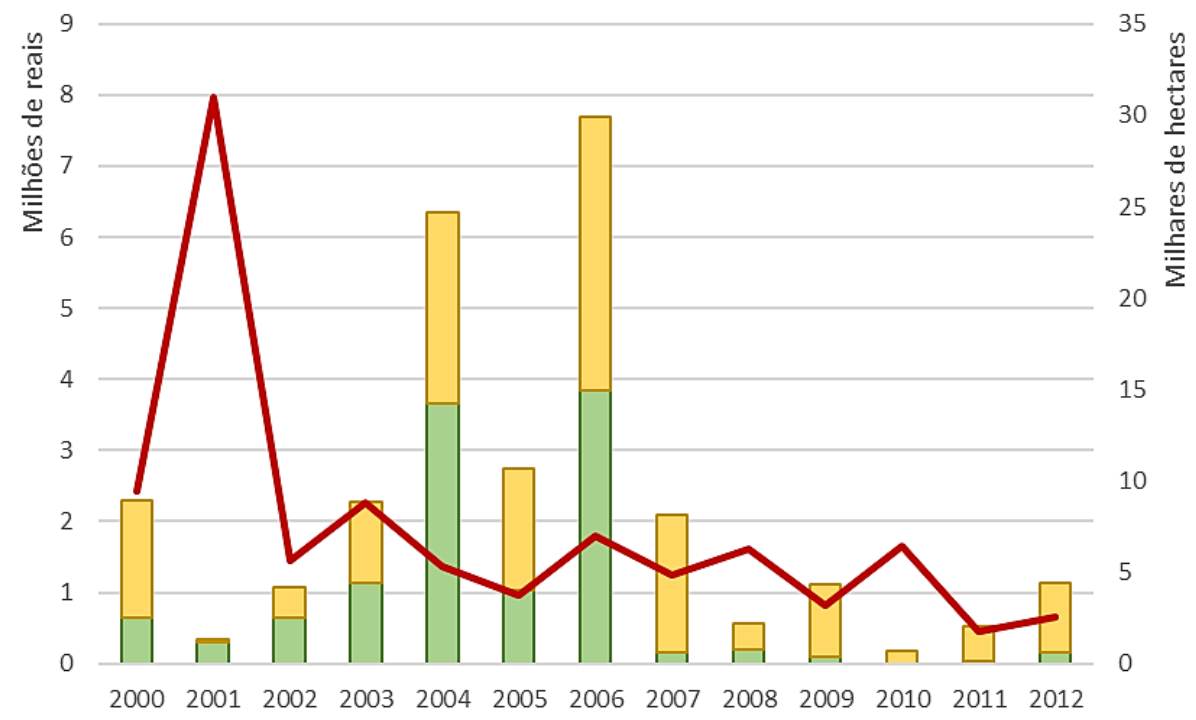

Prainha

$\square$ Agricola $\square$ Pecuaria $\square$ Desmatamento

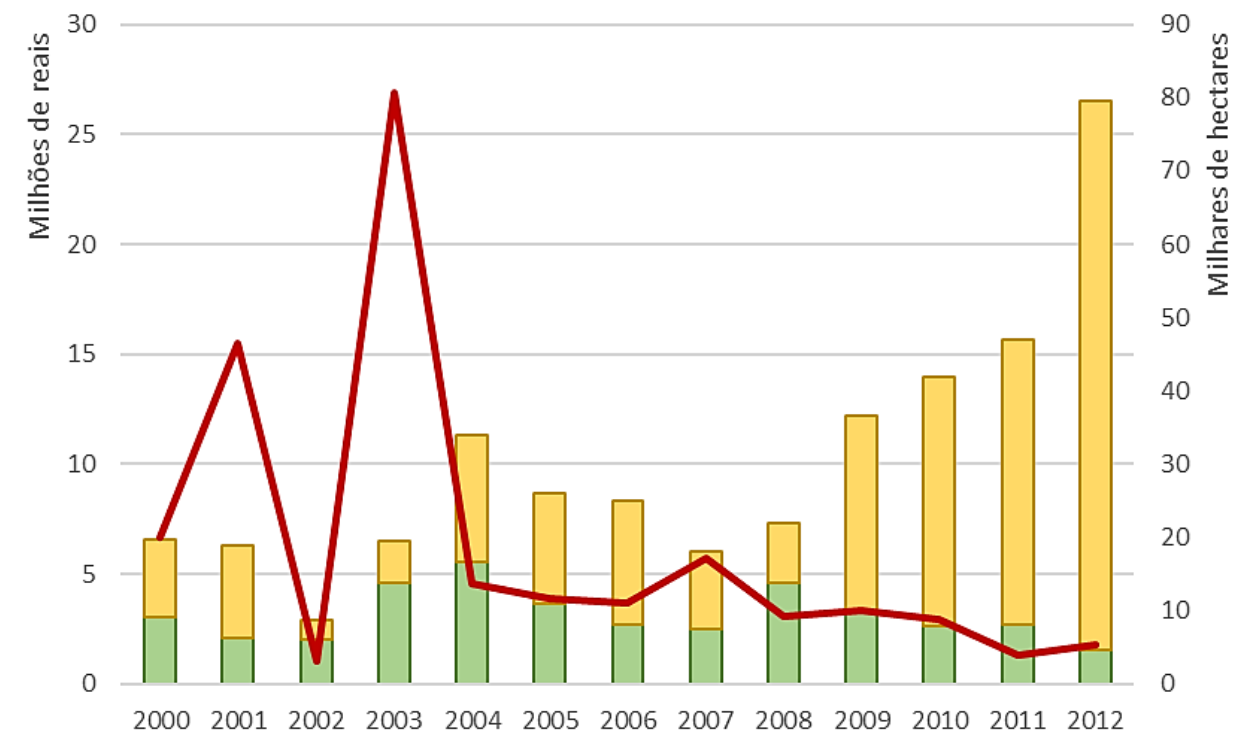

Uruará

$\square$ Agricola $\square$ Pecuaria $\square$ Desmatamento

Figura 16 - Crédito rural e desmatamento em Prainha e Uruará Fonte: Adaptado de PRODES (INPE, 2016) e BACEN (2016).

Segundo Nepstad et al. (2014) e Gibbs et al. (2015) o recuo no desmatamento foi acompanhado pelo ganho em produtividade na produção de grãos e na pecuária. Os autores apresentam dados coincidentes ao incremento recente no crédito rural conforme apresentado. Outro fator pouco explorado na literatura é a conversão não contabilizada de floresta secundária para expansão de áreas agrícolas e pastagens, como será trabalhado adiante. 


\section{FUNDAMENTAÇÃO TEÓRICA}

Dizer que [...] todas as florestas tropicais primárias serão "destruídas" até o final do século não é afirmar que em 2000 não haverá florestas de qualquer tipo ou que toda flora e fauna da floresta existente desaparecerão, mas é provável que [...] todas as florestas maduras ou quase maduras desaparecerão.

(RICHARDS, 1971, p.171)

\subsection{DEFINIÇÃO DE FLORESTA SECUNDÁRIA}

O uso habitual do termo floresta secundária está em conformidade com o conceito de regeneração florestal após o desmatamento (FINEGAN, 1992), mas a sua formação pode ser compreendida por causa de todo o impacto humano sobre as terras florestadas, sem considerar as plantações florestais (BROWN; LUGO, 1990). Virtualmente todas as florestas tropicais sofreram algum tipo de alteração provocada pelo homem (CORLETT, 1994). Como resultado deste amplo antropismo, a floresta secundária é uma característica cada vez mais comum nas paisagens tropicais em todo o mundo (RIBEIRO; BRUNA; MANTOVANI, 2010).

Aproximadamente 9,5 milhões de quilômetros quadrados de florestas tropicais foram perdidos entre 1700 e 1995 (WILLIAMS, 2010) face à expansão de múltiplas fronteiras de ocupação humana nos países tropicais. Na Amazônia brasileira foram perdidos $762.464 \mathrm{~km}^{2}$ de cobertura original de floresta até 2014 segundo os dados do TERRACLASS (INPE-CRA, 2016). Deste total $173.387 \mathrm{~km}^{2}$ (22,74\%) eram recobertos por floresta secundária. Os mesmos dados revelam que haviam 3.181,51 $\mathrm{km}^{2}$ de terras antropizadas na área de estudo em 2014, e $1.281,33 \mathrm{~km}^{2}(40,27 \%)$ destas terras eram recobertas por floresta secundária.

A formação da floresta secundária é resultado da recuperação de distúrbios passados; muitas formações florestais imaginadas como intactas possuem um histórico de cultivo agrícola e extração de madeira (WHITE; OATES, 1999) graças ao legado biológico presente no solo preservado, apesar da degradação. Apesar da baixa variedade de espécies, ela tem grande importância para o restabelecimento das funções dos ecossistemas e estoques de nutrientes perdidos da floresta original, bem 
como maior taxa de absorção de carbono de uma floresta madura (POORTER et al., 2016).

A vegetação remanescente, na forma de árvores isoladas, cercados, cercas vivas ou a rebrota, são base da "memória ecológica", legado biológico interno ou externo a uma regeneração inicial, e que representa espécies anteriormente presentes na paisagem local (BENGTSSON et al., 2013; CHAZDON; ARROYO, 2003). A memória ecológica desempenha um papel fundamental na regeneração florestal, que pode ser comprometida sem uma adequada fonte de espécies para a colonização. Outro fator fundamental é o tempo, pois o desenvolvimento de uma floresta madura pode levar décadas (Tabela 5).

A diversidade de espécies aumenta rapidamente quando os distúrbios iniciais são pequenos, o uso da terra é de curta duração e o desmatamento está incorporado na matriz florestal, como é comum nos sistemas de cultivo da agricultura itinerante, com longos períodos de pousio (CHAZDON, 2014). Segundo a autora, dez condições locais e paisagísticas favorecem a colonização rápida e diversa de antigos campos cultivados ou pastagens em regiões tropicais:

1) conservação do horizonte superficial do solo (solo vegetal);

2) proximidade a fragmentos florestais;

3) rebrota a partir de raízes ou troncos de árvores;

4) banco de sementes do solo intacto;

5) presença de sementes de espécies lenhosas de sucessão precoce e tardia, na chuva de sementes;

6) colonização contínua de espécies nativas a partir das redondezas;

7) supressão de ervas daninhas pela colonização de arbustos e árvores pioneiras;

8) diversidade animal e microbiológica (insetos, vertebrados, fungos);

9) proteção contra o fogo recorrente;

10) proteção contra a caça e a coleta excessiva de serapilheira e produtos florestais.

Por outro lado, o desmatamento de larga escala pode eliminar as fontes locais de colonização de espécies, erodindo a memória ecológica e comprometendo o potencial para a regeneração natural (GOMEZ-POMPA, 1971). A remoção do horizonte superficial do solo pelo trator de esteira ou pela mineração elimina o banco 
de sementes e a matéria orgânica do solo, podendo levar à erosão e impedir o restabelecimento da maioria das espécies de plantas. A exploração da madeira e o desmatamento estão associados à fragmentação florestal, ao aumento da caça e a penetração do fogo na floresta (PERES, 2001). A recorrência do fogo leva a redução das árvores antigas a alterações na composição de espécies e na própria forma da sucessão florestal, além da devastação das populações de animais (PERES et al., 2003; BARLOW; PERES, 2004).

Estudos sobre a regeneração florestal mostram que a florestal tropical pode rapidamente recuperar a área basal, a biomassa e a diversidade de espécies caso a memória ecológica seja preservada, ou que ela pode ser comprometida pelo histórico do uso da terra (CHAZDON, 2008). Ao analisar a estrutura de um fragmento florestal na Reserva Florestal Adolpho Ducke, em Manaus, Ribeiro, Bruna e Mantovani (2010) conclui que a regeneração herbácea é dependente do tratamento da área após o corte raso, e recomenda que a estratégia de restauração de uma determinada área deve ser precedida pelo histórico do uso da terra pois isso influenciará o modelo biológico de restauro e poderá evitar esforços redobrados.

No Capítulo 3 deste estudo foi apresentado que o histórico de uso e ocupação da área de estudo remonta ao século XVII com o início da colonização da Amazônia, mas a existência de evidências arqueológicas como a Terra Preta de Índio, mostra a presença humana até 10.000 anos A.P. O predomínio de atividades extrativistas até a primeira metade do século $X X$ produziu alterações restritas no uso da terra na Amazônia e na região de Santarém sem comprometimento da memória ecológica do solo. A partir da década de 1940 a ocupação da região torna-se uma política de Estado; ações estatais e privadas estruturantes nas décadas seguintes estimulam o crescimento urbano e a expansão das áreas agrícolas e pastagens.

A expansão das áreas agrícolas e pastagens introduzem as técnicas de mecanização e agroquímicos arrasam o horizonte superficial do solo, a matéria orgânica e a memória ecológica. Em contraste, a agricultura itinerante envolve pouca mecanização e emprega longos períodos de pousio favorecendo a regeneração florestal, apesar de reconhecida baixa produtividade e problemas que o manejo inadequado do fogo pode trazer.

Compreender a natureza das florestas tropicais como sistemas adaptativos complexos permite planejar formas de interação com as florestas para promover processos de regeneração natural. Assim, a manutenção de ricos ecossistemas não 
exige necessariamente uma política de intervenção, mas ela pode emergir do envolvimento de atividades humanas compatíveis com os processos ecológicos (CHAZDON; ARROYO, 2003).

O desmatamento na Amazônia é relativamente um fenômeno recente (FEARNSIDE, 2005), quando comparado a todos os processos envolvidos no histórico de uso da terra na região. O mapeamento dos estágios de sucessão secundária embasa a identificação de áreas para expansão agrícola e pecuária, e é um instrumento que pode auxiliar o planejamento para o restauro ecológico conforme sugere Ribeiro, Bruna e Mantovani (2010).

Chazdon (2012) identifica estratégias de sucessão secundária em quatro períodos, apresentados de forma sucinta na Tabela 5 . Estes períodos são de grande importância para a abordagem construída neste trabalho, servindo como referência ao mapeamento de três classes de sucessão secundária (SS): SS1 (5 a 15 anos). SS2 (16 a 30 anos), SS3 (mais de 30 anos). O pousio não está contemplado devido à impossibilidade de individualizar como classe de mapeamento com imagens LANDSAT, e a classe floresta madura (com mais de 200 anos de regeneração) estão contempladas na classe SS3 devido à falta de imagens orbitais para tal período de sucessão florestal.

Tabela 5 - Estágios de sucessão secundária na Amazônia

\begin{tabular}{|c|c|c|c|c|}
\hline \multicolumn{5}{|c|}{ Tempo decorrido desde o distúrbio / Estágio de sucessão } \\
\hline $0-5$ anos & $6-15$ anos & $16-30$ anos & 31 a 50 anos & $>200$ anos \\
\hline Pousio & $\begin{array}{l}\text { Início do } \\
\text { povoamento }\end{array}$ & $\begin{array}{l}\text { Exclusão de } \\
\text { espécies } \\
\text { intolerantes à } \\
\text { sombra }\end{array}$ & $\begin{array}{l}\text { Reinício do } \\
\text { sub-bosque }\end{array}$ & Floresta Madura \\
\hline \multicolumn{5}{|c|}{ Classe de mapeamento dos estágios de sucessão secundária (SS) } \\
\hline SS1 & SS1 & SS2 & SS3 & SS3 \\
\hline
\end{tabular}

Fonte: Adaptado de Chazdon (2012).

\subsection{LEGISLAÇÃO PERTINENTE AO CORTE E CONSERVAÇÃO DE FLORESTA SECUNDÁRIA}

A não contabilização dos dados relativos ao desmatamento de floresta secundária no PRODES (ALMEIDA et al., 2010) criou um hiato em relação ao monitoramento e fiscalização do desmatamento de florestas secundárias na 
Amazônia, salvo o recente programa de mapeamento do uso e cobertura da terra da classe desmatamento do PRODES, o TERRACLASS (INPE-CRA, 2016).

Esta lacuna técnica permitiu que proprietários rurais de posse de licenças municipais ou estaduais para limpeza de pasto ou pousio utilizassem deste instrumento para desmatar floresta secundária de estágio médio ao estágio avançado de regeneração. Estas dúvidas estenderam-se ao monitoramento dos fornecedores das cadeias de suprimentos conforme os critérios estabelecidos nos acordos setoriais da Moratória da Soja e do TAC da Pecuária.

O Código Florestal (BRASIL, Lei 4.771, 1965) reconhecia a importância da conservação das formações florestais fluviais, da formação de corredores ecológicos como estratégia complementar a criação de unidades de conservação, e para proteção de formações florestais inexploradas na Amazônia. Para alcançar estes objetivos, ele estipulou as Áreas de Preservação Permanente e as Reservas Legais.

Em relação às Áreas de Preservação Permanente, o Código Florestal (BRASIL, 1965) estipulava limites mínimos de faixa marginal de floresta em torno de nascentes, massas d'águas e leito máximo de cursos fluviais. Estes limites e critérios foram modificados no Novo Código Florestal (BRASIL, 2012). No entanto, apesar da reconhecida importância da regeneração florestal à recuperação dos recursos hídricos, a pressão para consolidação e expansão de áreas agropecuárias levou ao abrandamento dos critérios para a recuperação de passivos de Reserva Legal.

O Código Florestal (BRASIL, 1965) estipulava que a Reserva Legal de uma propriedade situada no bioma Amazônia deveria corresponder à $80 \%$ da área total da propriedade, ou $50 \%$ nas áreas de consolidação definidas em Zoneamento EcológicoEconômico ou os municípios com $80 \%$ (ou mais) com área recoberta por unidades de conservação e terras indígenas. Não havia anistia e, portanto, o proprietário rural com passivo deveria recuperar a cobertura vegetal até o limite indicado na lei.

O Artigo 67 do Novo Código Florestal, (BRASIL, Lei 12.727, 2012) colocou um novo referencial à ocupação nas terras localizadas no bioma Amazônia. O referido artigo define que a área de uma supressão florestal realizada até 22 de julho de 2008 em imóvel de até quatro módulos fiscais é considerada uso consolidado da propriedade. Assim, o proprietário rural que desmatou antes desta data e também aquele que não recuperou o passivo de Reserva Legal conforme estipulado na Lei 4.771 (BRASIL, 1965) foi anistiado pela lei vigente, conforme o próprio artigo explicita: 
Nos imóveis rurais que detinham, em 22 de julho de 2008, área de até 4 (quatro) módulos fiscais e que possuam remanescente de vegetação nativa em percentuais inferiores ao previsto no art. 12, a Reserva Legal será constituída com a área ocupada com a vegetação nativa existente em 22 de julho de 2008, vedadas novas conversões para uso alternativo do solo.

(BRASIL, Lei 12.727, 2012)

O Novo Código Florestal (BRASIL, 2012) também introduz um novo instrumento, com base em experiências bem-sucedidas em unidades da federação como o Pará, o Cadastro Ambiental Rural (CAR). O CAR é um documento auto declaratório, no qual o proprietário do imóvel rural (ou o representante dele) declara os limites georreferenciados e as informações do domínio da propriedade.

O CAR em pouco tempo se constituiu no principal instrumento de gestão de terras privadas introduzida nacionalmente no Capítulo VI do Novo Código Florestal (BRASIL, 2012), sendo hoje condição necessária para o produtor rural solicitar crédito rural e comprovar sua adimplência fiscal e ambiental. O Banco Central tem progressivamente criado instrumentos de regulação que limitem o acesso ao crédito rural ao nada consta.

Dentre os instrumentos regulatórios do Banco Central estão a Resolução 3.545 (BACEN, 2008), que exige a comprovação de regularidade ambiental conforme as exigências do Código Florestal para obtenção de financiamento agropecuário na Amazônia, a Resolução 4.487 (BACEN, 2016) estabelece no Artigo 1 - item 12-A:

A partir de 26 de maio de 2017 o financiamento de atividades
agropecuárias ficará condicionada apresentação de recibo de
inscrição no Cadastro Ambiental Rural (CAR), instituído pela Lei
no 12.651 , de 2012, que se constitui instrumento suficiente para
atender à condição prevista no art. 78-A da referida Lei. (BACEN, 2016)

Uma fragilidade exposta pelo CAR também é dada a natureza autodeclaratória do documento, o preenchimento de informações inverídicas como a delimitação de grilagens sobre unidades de conservação e terras indígenas, a titularidade de laranjas (quando o proprietário quer se omitir por razões diversas) e a fragmentação de uma grande propriedade em múltiplos CAR de até quatro módulos fiscais, com fins a não recuperação de passivos. 
Este desvirtuamento do conceito de imóvel rural, dado não necessariamente por um lote, mas sim pela quantidade de lotes contíguos pertencentes a um mesmo titular, foi corrigida pela Instrução Normativa $n^{\circ} 02$ (MMA, 2014), que dispõe sobre as regras e prazo de inscrição no CAR para todos os imóveis no Brasil. Dentre estas regras, o Artigo 36 veda o fracionamento do imóvel rural em múltiplos CAR.

Apesar da solução para o fracionamento do imóvel, algumas dúvidas persistem em relação às condições que a supressão de vegetação poderá ser aprovada para uma propriedade rural:

- a floresta secundária (juquira) é considerada pousio ou vegetação nativa?

- como fazer o CAR e comprovar que a área de pousio que o produtor rural limpou (com ou sem licença) após 22 de julho de 2008 não era vegetação nativa?

- como o técnico da Secretaria de Estado de Meio Ambiente (SEMA) pode fornecer uma licença de limpeza de pousio/pasto sem a dúvida que isto não é um artificio do produtor rural para desmatar vegetação nativa?

- como o produtor rural pode comprovar ao Banco ou ao seu cliente que não desmatou após 22 de julho de 2008?

Cabe mencionar que o Artigo $1^{\circ-}$ A Inciso XXIV do Novo Código Florestal (BRASIL, 2012) define o pousio como:

Prática de interrupção temporária de atividades ou usos agrícolas, pecuários ou silvicultura por, no máximo, 5 (cinco) anos, para possibilitar a recuperação da capacidade de uso ou da estrutura física do solo.

(BRASIL, Lei 12.727, 2012)

O Novo Código Florestal em relação a sucessão secundária resume-se a diferenciar vegetação nativa, pousio e área de uso alternativo do solo (uso antrópico), a Secretaria de Meio Ambiente do Pará prestou novamente grande contribuição recente à conservação ao publicar a Instrução Normativa oㅡ 02 (SEMAS-PA, 2014) e a Instrução Normativa $n^{\circ} 05$ (SEMAS-PA, 2015), que especificam os procedimentos para realização de limpeza de áreas abandonadas (pousio) e de supressão de vegetação secundária, com critérios baseados em estágios de sucessão, apresentados na Tabela 6.

Além de esta Instrução normativa restringir o licenciamento através de critérios de idade e de desenvolvimento da área basal da vegetação lenhosa de maior porte, 
também considera a proporção de floresta primária remanescente no município paraense e a sobreposição do CAR da propriedade em licenciamento com os dados do PRODES (INPE, 2016). Serão passíveis de licenciamento apenas polígonos classificados como "desmatamento", segundo o método empregado no PRODES, visto que esta base de dados não possui em sua legenda a classe "regeneração" ou "vegetação secundária".

Tabela 6 - Estágio de sucessão e licenciamento no Estado do Pará

\begin{tabular}{l|l|l}
\multicolumn{1}{c|}{ Estágio de Sucessão } & \multicolumn{1}{c}{ Licença } & \multicolumn{1}{c}{ Área basal } \\
\hline Até 5 anos (inicial) & Necessita licença & Até $5 \mathrm{~m}^{2} /$ hectare \\
\hline 5 a 20 anos (inicial) & Necessita licença & $5 \mathrm{~m}^{2}$ a $10 \mathrm{~m}^{2} /$ hectare \\
\hline Mais que 20 anos (médio) & Não licenciável & $=0 \mathrm{ou}>10 \mathrm{~m}^{2} /$ hectare
\end{tabular}

Fonte: Instrução Normativa nº 02 (SEMAS-PA, 2014).

Assim, a legislação ambiental atual gerou uma lacuna de informação para o produtor rural em como estar em conformidade com esta regulamentação e, para o corpo técnico das secretarias estaduais de meio ambiente e profissionais que trabalham com dados de monitoramento, sobre como identificar quem desmatou vegetação nativa do estágio médio ao estágio avançado de regeneração sob o argumento (e licença) da limpeza de pousio.

\subsection{A CONTRIBUIÇÃO DOS ESTUDOS DE MUDANÇA NO USO DA TERRA AO MAPEAMENTO DE FLORESTAS SECUNDÁRIAS}

Ao propor um método para estimativa de floresta secundária na Amazônia, Almeida et al. (2010) aponta que o desmatamento de floresta secundária não é computado no monitoramento PRODES (INPE, 2016). Assim, o PRODES apresenta anualmente apenas a atualização da redução de uma máscara de cobertura florestal (ombrófila densa e aberta, apenas) que tem como origem o primeiro mapeamento do desmatamento no bioma Amazônia em 1988. Outras fisionomias (savana, campos e várzeas) são incluídas numa máscara chamada "Não floresta".

Assim, pode-se considerar o desmatamento na Amazônia como subestimado ao considerar apenas os dados PRODES como única fonte de referência. Os dados TERRACLASS (INPE-CRA, 2016) complementam o retrato oferecido pelo PRODES, 
qualificando os dados classificados como desmatamento no PRODES e são de grande utilidade para mapeamento em escalas médias baseados no uso de imagens de sensores orbitais de média resolução como o LANDSAT.

O TERRACLASS é uma iniciativa louvável e tem fornecido dado reconhecidamente significativo, mas possui uma limitação técnica para análises na mudança de uso da terra - a resolução temporal, pois o levantamento contempla os anos de 2004, 2008, 2010, 2012 e 2014. Outros estudos procuraram identificar não só a extensão total de floresta perdida, como qual a proporção de área desmatada tem registrado regeneração florestal.

Estimativas de Fearnside (2005) mostram que haviam $169.900 \mathrm{~km}^{2}$ de terras desmatadas na Amazônia brasileira até 1978. Com base nos dados PRODES (INPE, 2016), foram perdidos entre $15.000 \mathrm{~km}^{2}$ e $20.000 \mathrm{~km}^{2}$ entre 1979 e 2008 ao ano, e perto de $6.300 \mathrm{~km}^{2}$ desde 2009 (Tabela 7). Estes dados mostram a ascensão das taxas de desmatamento entre 1979 e 2008 e a queda, a partir de 2009, decorrente de fatores abordados anteriormente no Capítulo 3.

Tabela 7 - Contribuição ao desmatamento na Amazônia por década

\begin{tabular}{|c|c|c|c|}
\hline Período & Perda em Km² & Contribuição (\%) & Media \\
\hline até 1978 & 169.900 & $22.28 \%$ & - \\
\hline 1979 a 1988 & 191.743 & $25.15 \%$ & $19.174,3$ \\
\hline 1989 a 1998 & 163.938 & $21.50 \%$ & $16.393,8$ \\
\hline 1999 a 2008 & 186.331 & $24.44 \%$ & $18.633,1$ \\
\hline 2009 a 2016 & 50.552 & $6.63 \%$ & 6.319 \\
\hline Total & 762.464 & $100.00 \%$ & - \\
\hline
\end{tabular}

Fonte: Adaptado de Fearnside (2005) e PRODES (INPE, 2016).

Segundo Fearnside (1996), $195.000 \mathrm{~km}^{2}$ das terras desmatadas eram recobertas por floresta secundária até 1990. Usando dados de uso da terra de escala continental, Neff et al. (2006) estima que a extensão de floresta secundária na Amazônia brasileira passou de 29.000 km² (em 1978) para 161.000 km² (em 2002). Com outro método, os dados do TERRACLASS (INPE-CRA, 2016) mostram que a extensão de floresta secundária variou de 101.000 km² (em 2004) para 173.000 km² (em 2014).

Apesar das fontes de dados distintas estes dados sobre a extensão das florestas secundárias mostram uma variação considerável que, indiscutivelmente, pode ser atribuída às diferenças na metodologia para obtenção e tratamento dos dados, mas também pode ser considerada a recorrência do desmatamento, ou 
seja, a derrubada da floresta secundária poucos anos após o corte da floresta madura, e que a extensão total de floresta secundária variou entre $100.000 \mathrm{~km}^{2}$ e $200.000 \mathrm{~km}^{2}$ desde 1990, enquanto a extensão total de área desmatada para o mesmo período passou de cerca de $380.000 \mathrm{~km}^{2}$ para pouco mais de $760.000 \mathrm{~km}^{2} \mathrm{em} 2016$.

Portanto, a redução na extensão total de floresta secundária na Amazônia brasileira não é absoluta, mas proporcional, pois a demanda de terra para expansão agropecuária exigiu não apenas a conversão de floresta madura para novas áreas de cultivo e pastagem, como também a conversão de outras áreas em estágio médio ou avançado de regeneração florestal que estavam simplesmente abandonadas ou inseridas no ciclo da agricultura itinerante.

Ao analisar os dados TERRACLASS (INPE-CRA, 2016) para a área de estudo verifica-se uma significativa redução de floresta secundária como pode ser verificado na Tabela 8 e na Figura 17, para 11 classes de uso e cobertura da terra. (Nota-se que - TERRACLASS possui uma máscara fixa para as classes "massa d'água" e "não floresta" (cerrado e várzea), enquanto a classe "área não observada" (formada por sombra e nuvens) é extremamente variável, conforme nota-se no Quadro A da Figura 17.

Outra característica é a não variabilidade da classe "floresta" como mostra o Quadro B da Figura 17. Apesar de esperado, diferenças no comportamento espectral de alvos entre diferentes períodos e a presença de nuvem e sombra produzem variações significativas na cobertura florestal mapeada. A solução aplicada no PRODES e no TERRACLASS é a criação também de uma máscara para a categoria floresta a partir da mais recente imagem orbital disponível sem nuvens.

O Quadro C da Figura 17 mostra a distribuição das demais classes (sem máscaras), com predominância de floresta secundária e variação significativa das classes "pasto limpo", "pasto sujo" e "regeneração com pasto"; as classes "agricultura anual" e "área urbana" mantiveram tendência de crescimento. A distribuição geográfica das classes de uso e cobertura da terra do TERRACLASS é apresentada no Mapa 2 para os anos de 2004 e 2014. 
Tabela 8 - Uso e cobertura da terra na área de estudo

\begin{tabular}{|l|c|c|c|c|c|}
\hline Categoria & 2004 & 2008 & 2010 & 2012 & 2014 \\
\hline Agricultura anual & $14.224,65$ & $28.618,99$ & $61.470,6$ & $65.906,61$ & $59.074,07$ \\
\hline Área não observada & $21.039,56$ & $72.569,82$ & $2.128,69$ & $1.874,04$ & $8.501,53$ \\
\hline Área urbana & 4467,25 & 6119,22 & 7191,25 & $8.641,50$ & $9.639,22$ \\
\hline Desmatamento & $11.155,69$ & $3.792,70$ & $3.449,45$ & 2024,09 & 480,35 \\
\hline Floresta & $748.768,80$ & $715.119,1$ & $706.210,8$ & $702.278,20$ & $700.207,4$ \\
\hline Floresta secundária & $105.304,50$ & $96.581,57$ & $117.090,5$ & $195.096,20$ & $128.133,9$ \\
\hline Hidrografia & $29.440,19$ & $29.419,56$ & $29.440,19$ & 29440,20 & $29.440,19$ \\
\hline Mosaico de ocupações & $32.046,91$ & $1.1351,28$ & $45.957,86$ & 11351,60 & $10.037,78$ \\
\hline Não floresta & $8.110,09$ & $8.111,15$ & $8.110,09$ & $8.110,09$ & $8.110,09$ \\
\hline Outros & $1.610,56$ & 604,91 & $1.018,076$ & $3.172,50$ & 562,36 \\
\hline Pasto limpo & $76.049,69$ & 73032,92 & 20624,98 & $31.287,38$ & $89.801,97$ \\
\hline Pasto sujo & $6.574,60$ & $18.258,69$ & $22.936,29$ & $10.829,78$ & $11.920,65$ \\
\hline
\end{tabular}

Dados em hectares.

Fonte: Adaptado de TERRACLASS (INPE-CRA, 2016).

Tal como em PRODES (INPE, 2016) e TERRACLASS (INPE-CRA, 2016), Carreiras et al. (2014) aplicaram a mesma técnica da máscara de floresta como solução para o mapeamento de três categorias de cobertura florestal (não floresta, floresta secundária, floresta madura) para três diferentes áreas em Manaus (Reserva Florestal Adolpho Ducke), Santarém (FLONA Tapajós) e um projeto de assentamento (PA) em Machadinho d'Oeste (Rondônia). O fragmento em Santarém do estudo de Carreiras et al. (2014) considerou uma área de $1.118 \mathrm{~km}^{2}$, enquanto o presente trabalho considerou uma área de estudo com $11.124 \mathrm{~km}^{2}$.

O método empregado compreendeu o uso combinado de uma classificação supervisionado para imagens LANDSAT anteriores a 2006, e o uso de GEOBIA para imagens entre 2007 e 2011 baseados nos índices de vegetação NDVI e NDWI (ver lista de siglas e definição no Capítulo 5). Como resultado identificou variação substancial na extensão de floresta secundária na comparação entre cada ano analisado e a viabilidade do uso das imagens LANDSAT para os objetivos desejados. 
A)

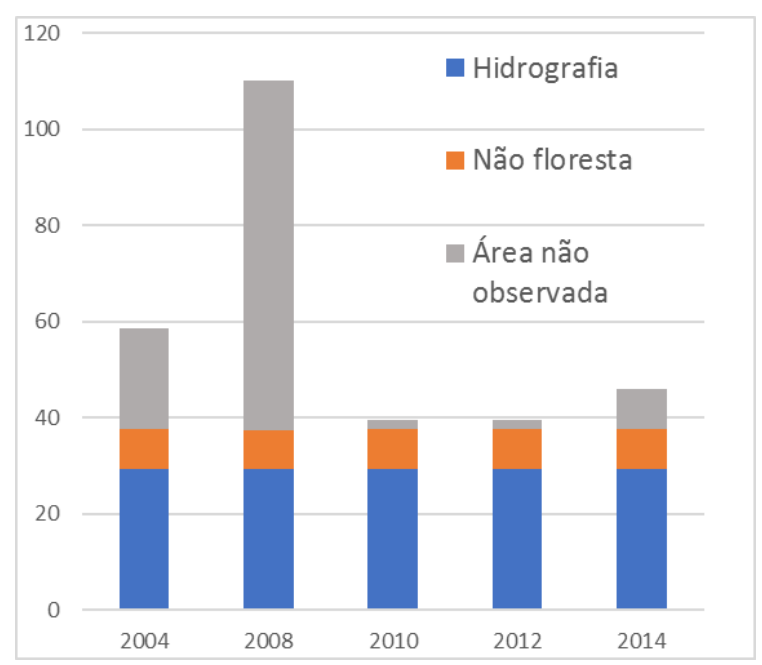

B)

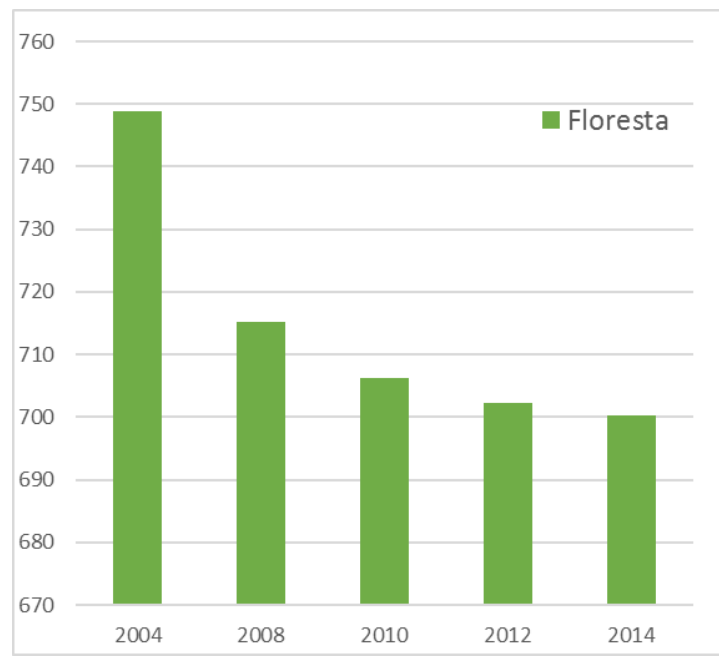

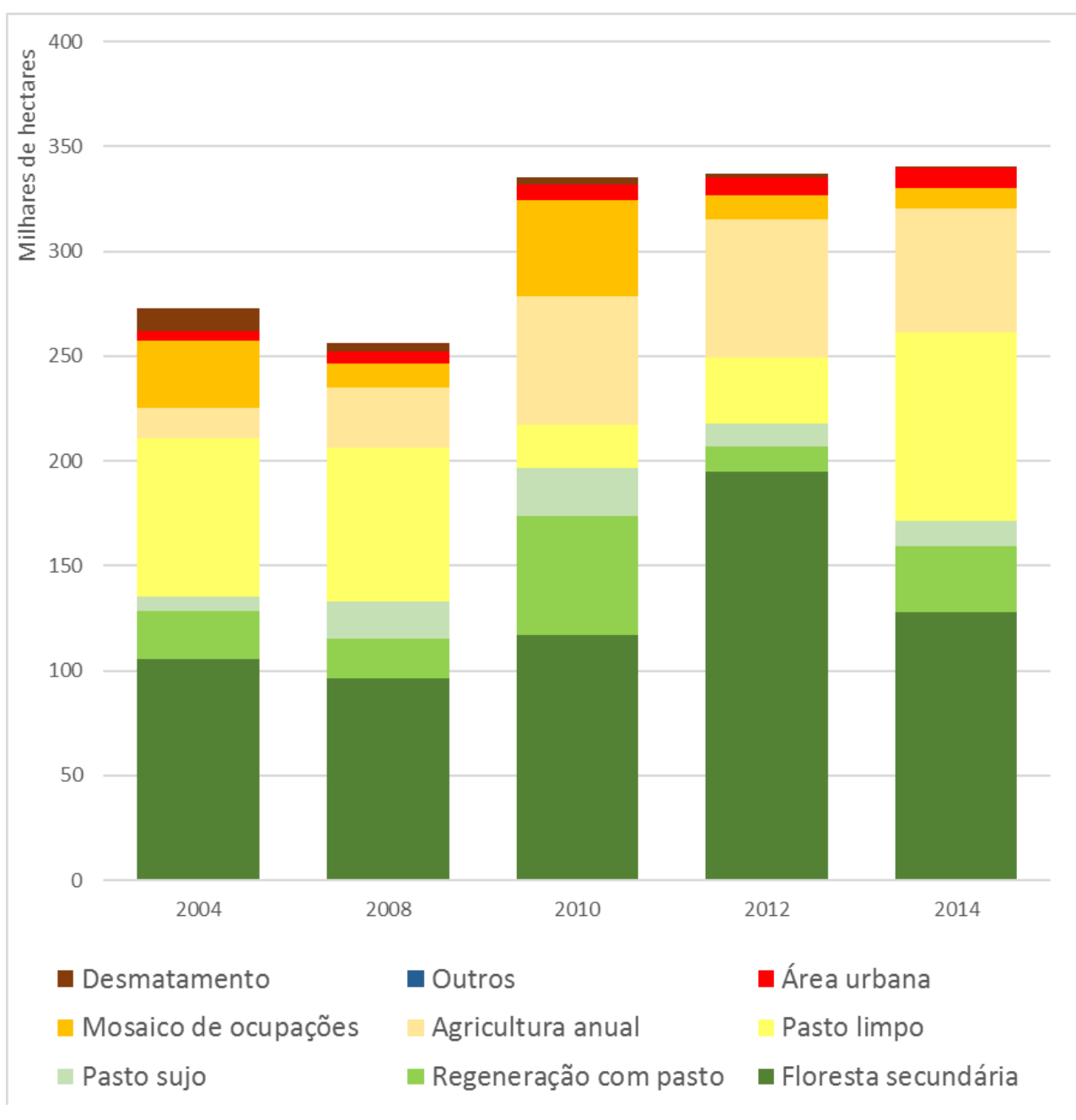

C)

negeneração com pasto

Área urbana

Pasto limpo

Figura 17 - Evolução das classes de mapeamento no TERRACLASS

Fonte: Adaptado de TERRACLASS (INPE-CRA, 2016). 


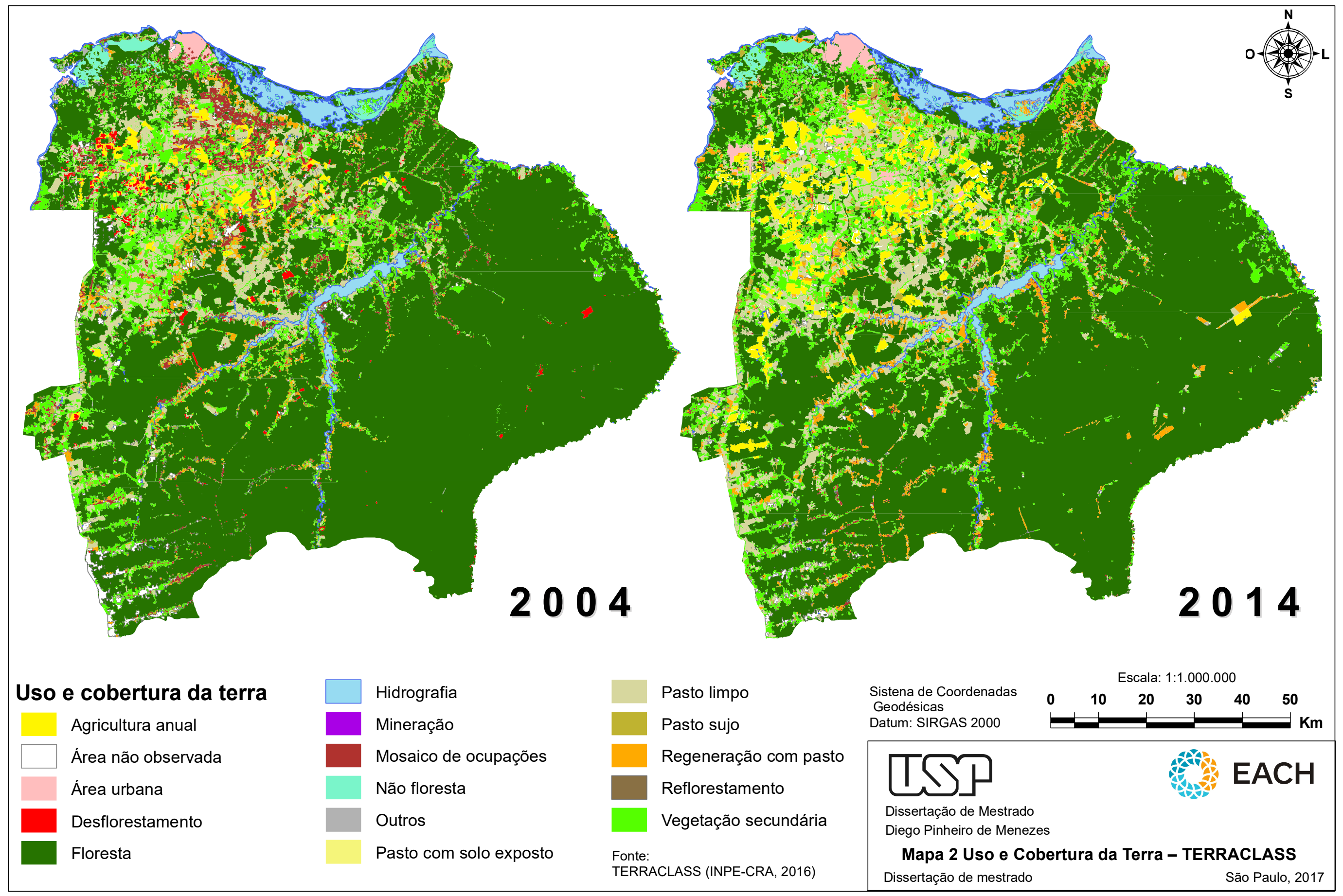




\section{MÉTODO, MATERIAIS E PROCEDIMENTOS}

O estudo da sucessão secundária requer a integração de métodos de pesquisa convencionais locais específicos na ecologia da vegetação e dados etnográficos com escalas mais inclusivas, por meio da análise de sensoriamento remoto dos padrões de uso e cobertura da terra.

(MORAN; BONDIZIO, 1998, p.94)

\subsection{MÉTODO APLICADO}

A abordagem inicialmente apresentada no projeto de pesquisa tinha como referência principal o trabalho de Souza et al. $(2005,2013)$, que propôs a utilização do Índice Normalizado de Diferença de Fração (NDFI), acreditando ser possível utilizar este Índice de Vegetação e uma árvore de decisão adaptada para o mapeamento de floresta secundária.

O NDFI é um índice obtido a partir da razão entre quatro diferentes frações (ou bandas sintéticas) de pixel puro propostas para uma classificação multiespectral (ADAMS et al., 1993). Estas quatro imagens sintéticas resultantes são geradas em um modelo de mistura espectral e representam a vegetação "verde" ou fotossintética (GV), a sombra (shade) a vegetação seca ou não fotossintética (NPV) e o solo (soi).

Para se obter o NDFI é necessário aplicar a seguinte equação:

$$
N D F I=\frac{G V \text { shade }-(N P V+\text { Soil })}{\text { GVshade }+(N P V+\text { Soil })}
$$

Para se obter a componente GVshade é necessário realizar uma razão entre as frações vegetação fotossintética e sombra, com esta outra equação:

$$
\text { GVshade }=\frac{G V}{100-\text { shade }}
$$

A classificação multiespectral baseada em frações de pixel puro é de grande versatilidade devido à similaridade de parâmetros entre imagens de diferentes datas, favorecendo o desenvolvimento de estudos de mudança no uso da terra e produtos como o MAPBIOMAS (OBSERVATÓRIO DO CLIMA, 2015), uma iniciativa de 
organizações da sociedade civil para obter a classificação do uso e cobertura da terra para todos os biomas brasileiros, com base nas frações de pixel puro (ADAMS et al., 1993) e no NDFI (SOUZA et al., 2005, 2013), mas que ainda não contemplou a floresta secundária nas duas coleções publicadas até o momento.

Neste estudo, a revisão da bibliografia e a realização de classificações mostraram que o NDFI é ineficaz para o reconhecimento de floresta secundária pois as imagens sintéticas (as frações) eliminam aspectos de textura, padrão e tom da imagem de satélite - características essenciais para diferenciação de floresta secundária em relação à floresta madura (ou primária).

Outros estudos encontraram limitações na abordagem baseada em pixel 5 , como apontou Lucas et al. (1993), que encontrou grandes dificuldades em usar série temporal de imagens LANDSAT, índice de vegetação e modelo de mistura espectral para diferenciar floresta plantada de floresta secundária numa área na Reserva Ducke, em Manaus, e da impraticabilidade em reconhecer estágios diante das imagens e técnicas disponíveis naquele momento.

Estas características, mais a dominância de artigos sobre classificação baseada em pixel, na área de sensoriamento remoto nos últimos trinta anos, estimulou a procura por outra abordagem que explorasse outros parâmetros estruturais de uma imagem, como a cor, a textura, o tom, o padrão, a forma, o tamanho, entre outros, que até há pouco tempo podiam ser explorados apenas por intérpretes humanos (BLASCHKE et al., 2014; CASTILLA; HAY, 2008). Por isso optou-se pela mudança de abordagem para a Análise Geográfica Orientada a Objeto (GEOBIA), que permite o uso não só de propriedades espectrais do pixel como também da forma ou das relações de vizinhança com outros pixels.

Dentre os trabalhos consultados não há uma abordagem que contemple, simultaneamente, a aplicação de GEOBIA no mapeamento dos estágios de sucessão de floresta secundária e a mesma área de estudo. Assim, foi adaptado dos trabalhos de Carreiras et al. (2014) e de Piazza et al. (2016) uma abordagem que envolve GEOBIA e a mineração de dados para a classificação dos estágios de sucessão de floresta secundária. O fluxo com todas as atividades realizadas pode ser visto na Figura 18.

\footnotetext{
5 Pixel: acrônimo de Picture Element - o menor componente de uma imagem digital. Segundo Novo
} (2008), em sensoriamento remoto o pixel representa certa área da superfície terrestre. 


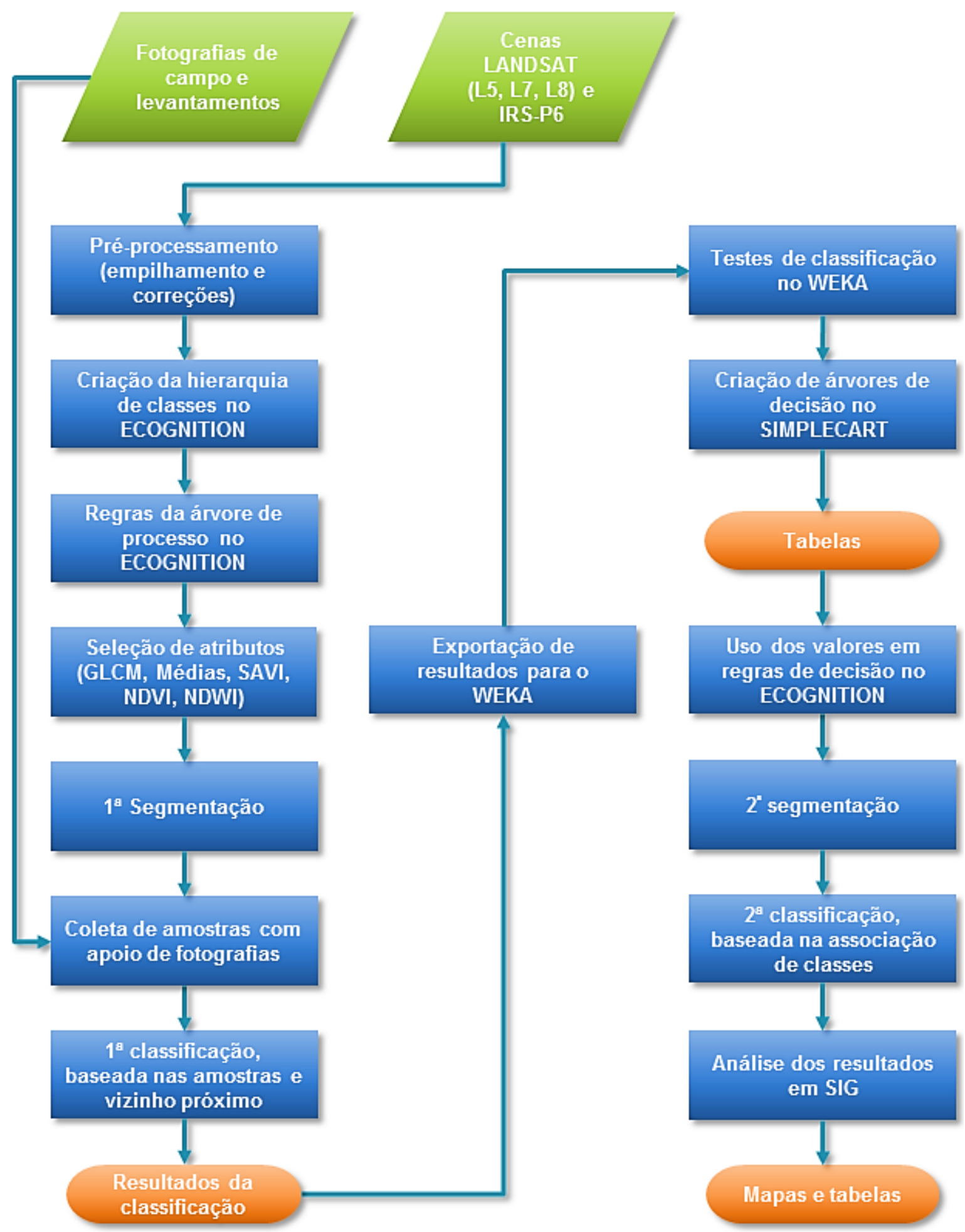

Figura 18 - Fluxograma aplicado à classificação de floresta secundária 


\subsection{MATERIAIS E EQUIPAMENTOS}

\subsubsection{Recursos de informática (Hardware e Software)}

- Microcomputador e equipamentos periféricos (scanner e impressora);

- Sistema de Informações Geográficas (SIG) para trabalhos com dados geográficos de estrutura vetorial e matricial - ARCGIS 10.4 (ESRI, 2015);

- Aplicativos para processamento digital de imagens: ENVI (EXILIS, 2014) e ECOGNITION (TRIMBLE, 2016);

- Aplicativo para análise exploratória e mineração de dados: WEKA (FRANK; HALL; WITTEN, 2016).

\subsubsection{Dados cartográficos}

- Mapeamento geológico organizado por Vásquez e Rosa-Costa (2008);

- Mapeamento geomorfológico da Folha SA-21 (RADAMBRASIL, 1976);

- Mapeamento pedológico da Folha SA-21 (RADAMBRASIL, 1976);

- Mapeamento fitogeográfico da Folha SA-21 (RADAMBRASIL, 1976);

- Dados de desmatamento da Amazônia brasileira acumulados até 2015 (PRODES-INPE, 2016);

- Dados de mapeamento do uso e cobertura da terra na Amazônia para os anos de 2004, 2008, 2010, 2012 e 2014 (TERRACLASS-INPE, 2016);

- Limites de Terras Indígenas e Unidades de Conservação obtidos da FUNAI e ICMBIO, respectivamente;

- Zoneamento Econômico Ecológico da BR-163 (VENTURIERI, 2008);

- Base Cartográfica Digital do Brasil ao Milionésimo (IBGE, 2013).

\subsubsection{Dados orbitais e obtidos por sensoriamento remoto}

- Série de imagens dos sensores LANDSAT-5-TM, LANDSAT-7-ETM+, LANDSAT8-OLI e IRS-P6-LISS3 relacionados no item 5.3.2 deste trabalho.

\subsubsection{Dados fotográficos}

- 2012 - Levantamento terrestre realizado pelo autor a serviço da organização The Nature Conservancy para monitoramento de propriedades rurais na região de Santarém;

- 2012 - Banco de acervo fotográfico do Google Street View (GOOGLE, 2017). 


\subsection{PROCEDIMENTOS}

\subsubsection{Características dos sistemas sensores utilizados}

A escolha das imagens de satélite para avaliação e monitoramento de recursos florestais e, igualmente, para análise de mudanças no uso e na cobertura da Terra, não deve considerar necessariamente a maior resolução espacial como fator predominante na seleção de um satélite de observação. Outros fatores precisam ser observados, como:

1) continuidade de coleta de dados pelo satélite ou missão;

2) intervalo de varredura do satélite;

3) faixas espectrais disponíveis;

4) largura da faixa de varredura do satélite;

5) disponibilidade para a área de estudo;

6) acesso e eventual custo de aquisição das imagens;

7) trabalhos anteriores realizados com os dados deste satélite ou missão.

Por todos os fatores mencionados acima, justifica-se a seleção dos dados coletados pelos satélites LANDSAT, desde 1984 até 2016. A única complementação para este estudo dá-se com a seleção de uma cena do satélite IRS-P6 para o ano de 2012, período não coberto pelo satélite LANDSAT 5, antes do fim oficial de sua operacionalidade em 2013.

\subsubsection{LANDSAT 5 e LANDSAT 7 (1984 a 2011)}

Um satélite foi lançado em 23 de julho de 1972 como parte de um programa da NASA chamado Satélite de Tecnologia de Recursos Terrestres (ERTS-1). Com o lançamento do segundo satélite o programa passou a ser chamado de LANDSAT (BOYD; DANSON, 2005). Tanto o primeiro como o segundo satélite tinham a bordo uma câmera multiespectral de média resolução a bordo (a MSS), o satélite logo se mostrou valioso para análise e monitoramento de recursos naturais.

Os dois satélites seguintes (LANDSAT 3 e LANDSAT 4) operaram por curto período, entre 1978 e 1983, ainda com a câmera MSS a bordo. Em 1985 viria a ser lançado o LANDSAT 5, o satélite de observação da Terra com maior tempo de operação, por ininterruptos 28 anos. 
A bordo do LANDSAT 5 uma nova câmera identificada pelas iniciais TM, com resolução espacial não mais de 82 metros, mas de 30 metros, e também uma melhor resolução espectral. Outro incremento foi na regularidade da varredura em comparação aos satélites anteriores, com intervalo de 16 dias para uma mesma órbita e ponto na superfície terrestre.

O LANDSAT 7 trouxe como inovação a captura de uma faixa espectral pancromática, através da câmera ETM, com resolução espacial de 15 metros. As demais faixas espectrais são rigorosamente as mesmas do LANDSAT 5. Outra característica mantida diz respeito às características para a operação $(705 \mathrm{~km}$ de altitude e $185 \mathrm{~km}$ de largura da faixa de varredura), garantindo não só o mesmo intervalo de varredura, como o mesmo sistema de grades baseado em órbita e ponto.

Graças as similaridades técnicas tratamos das características destes dois satélites neste único item. Na Tabela 9 estão resumidas as características espectrais e espaciais de ambos os satélites. As bandas (faixas espectrais) termal e pancromática não foram utilizadas neste estudo essencialmente devido a incompatibilidade da resolução espacial destas bandas com as demais e a disponibilidade da banda pancromática na câmera do satélite LANDSAT 5.

Tabela 9 - Resumo das características espectrais das câmeras dos satélites LANDSAT 5 (TM e LANDSAT 7 (ETM+)

\begin{tabular}{|l|c|c|c|}
\hline \multicolumn{1}{|c|}{ Nome da banda } & Resolução $(\mathbf{m})$ & $\begin{array}{c}\text { Comprimento da } \\
\text { banda }(\boldsymbol{\mu m})\end{array}$ & $\begin{array}{c}\text { Aplicado } \\
\text { no estudo }\end{array}$ \\
\hline 1 - Azul & 30 & $0,45-0,52$ & Sim \\
\hline 2 - Verde & 30 & $0,52-0,60$ & Sim \\
\hline 3 - Vermelho & 30 & $0,63-0,69$ & Sim \\
\hline 4 - Infravermelho próximo & 30 & $0,77-0,90$ & Sim \\
\hline 5 - Infravermelho médio I & 30 & $1,55-1,75$ & Sim \\
\hline 6 - Termal & 60 & $10,40-12,50$ & Não \\
\hline 7 - Infravermelho médio II & 30 & $2,11-2,29$ & Sim \\
\hline 8 - Pancromática (só L7) & 15 & $0,52-0,90$ & Não \\
\hline
\end{tabular}

Fonte: LANDSAT Web Page (USGS, 2017).

\subsubsection{IRS-P6 (2012)}

Desenvolvido pela Organização de Pesquisa Espacial da Índia (ISRO), o Indian Resource Sat é uma missão de observação da Terra com fins ao monitoramento de recursos naturais (principalmente florestais) e monitoramento agrícola. Uma parceria entre o INPE e o ISRO tem proporcionado o acesso a seus dados. Diferente dos 
satélites LANDSAT, a câmera LISS-3 do satélite IRS-P6A não opera na faixa do azul; portanto para efeito comparativo, é mantida a numeração das bandas equivalente às bandas do LANDSAT 5 e LANDSAT 7, com numeração iniciada na banda 2 (verde).

Tabela 10 - Resumo das características espectrais do satélite IRS-P6 (LISS3)

\begin{tabular}{|l|c|c|c|}
\hline \multicolumn{1}{|c|}{ Nome da banda } & $\begin{array}{c}\text { Resolução } \\
(\mathbf{m})\end{array}$ & $\begin{array}{c}\text { Comprimento da } \\
\text { banda }(\mu \mathrm{m})\end{array}$ & $\begin{array}{c}\text { Aplicado } \\
\text { no estudo }\end{array}$ \\
\hline 2 - Verde & 23,5 & $0,52-0,59$ & Sim \\
\hline 3 - Vermelho & 23,5 & $0,62-0,68$ & Sim \\
\hline 4 - Infravermelho próximo & 23,5 & $0,77-0,86$ & Sim \\
\hline 5 - Infravermelho médio I & 23,5 & $1,55-1,70$ & Sim \\
\hline
\end{tabular}

Fonte: LANDSAT Web Page (USGS, 2016).

\subsubsection{LANDSAT 8 (2013 a 2016)}

Lançado em fevereiro de 2013, como parte fundamental da missão de continuidade dos dados LANDSAT (LDCM), em substituição aos sensores LANDSAT 5 (descontinuado em 2013) e LANDSAT 7 (operacional, mas com falhas radiométricas desde 2003), o LANDSAT 8 é também o sensor dotado de câmera imaginadora (OLI) de maior amplitude espectral, abarcando 11 faixas espectrais (bandas) entre o visível e o infravermelho.

Tabela 11 - Resumo das características espectrais da câmera do satélite LANDSAT 8 (OLI)

\begin{tabular}{|l|c|c|c|}
\hline \multicolumn{1}{|c|}{ Nome da banda } & Resolução $(\mathbf{m})$ & $\begin{array}{c}\text { Comprimento da } \\
\text { banda }(\boldsymbol{\mu m})\end{array}$ & $\begin{array}{c}\text { Aplicado } \\
\text { no estudo }\end{array}$ \\
\hline 1 - Costeiro & 30 & $0,43-0,45$ & Não \\
\hline 2- Azul & 30 & $0,45-0,51$ & Sim \\
\hline 3 - Verde & 30 & $0,53-0,59$ & Sim \\
\hline 4 - Vermelho & 30 & $0,64-0,67$ & Sim \\
\hline 5 - Infravermelho próximo & 30 & $0,85-0,88$ & Sim \\
\hline 6 - Infravermelho médio I & 30 & $1,57-1,65$ & Sim \\
\hline 7 - Infravermelho médio II & 30 & $2,11-2,29$ & Sim \\
\hline 8- Pancromática & 15 & $0,50-0,68$ & Não \\
\hline 9 - Cirrus & 60 & $1,36-1,38$ & Não \\
\hline 10 - Termal I & 100 & $10,6-11,19$ & Não \\
\hline 11 - Termal II & 100 & $11,5-12,51$ & Não \\
\hline
\end{tabular}

Fonte: LANDSAT Web Page (USGS, 2017). 


\subsubsection{Seleção das imagens orbitais}

A listagem preliminar das imagens orbitais selecionadas, respectivamente, dos sensores LANDSAT 5 TM, IRS-P6 LISS 3, e LANDSAT 8 OLI identificadas para uso e processamento no trabalho de análise das áreas em regeneração e degradação florestal, considerando a área de estudo são apresentadas na Tabela 12

As informações sobre cobertura de nuvens ${ }^{6}$, expressas em porcentagens, foram obtidas dos metadados das respectivas cenas da série LANDSAT (5-TM, 7-ETM+, 8-OLI) disponíveis no catálogo EARTHEXPLORER (USGS, 2016), e também as cenas do sensor IRS-P6 (LISS3) disponíveis no Catálogo do INPE.

Tabela 12 - Cenas orbitais selecionadas para análise

\begin{tabular}{|c|c|c|c|c|c|c|c|c|c|}
\hline \multirow{2}{*}{ Ano } & \multirow{2}{*}{ Sensor } & \multirow{2}{*}{ Data } & \multicolumn{5}{|c|}{ Nuvens } & \multirow{2}{*}{$\begin{array}{c}\text { Elevação } \\
\text { Solar }\end{array}$} & \multirow{2}{*}{$\begin{array}{c}\text { Azimute } \\
\text { Solar }\end{array}$} \\
\hline & & & Total & ES & DS & EI & DI & & \\
\hline 2016 & L8 & 16/ago & 10,5 & $\mathrm{Nd}$ & $\mathrm{Nd}$ & $\mathrm{Nd}$ & $\mathrm{Nd}$ & 57,47 & 59,10 \\
\hline 2015 & L8 & 14/ago & 0,69 & $\mathrm{Nd}$ & $\mathrm{Nd}$ & $\mathrm{Nd}$ & $\mathrm{Nd}$ & 56,86 & 57,92 \\
\hline 2014 & L8 & 30/out & 6,17 & $\mathrm{Nd}$ & $\mathrm{Nd}$ & $\mathrm{Nd}$ & $\mathrm{Nd}$ & 64,6 & 116,99 \\
\hline 2013 & L8 & $25 /$ set & 2,2 & $\mathrm{Nd}$ & $\mathrm{Nd}$ & $\mathrm{Nd}$ & $\mathrm{Nd}$ & 65,21 & 86,29 \\
\hline 2012 & IRS-P6 & 01/ago & 0 & 0 & 0 & 0 & 0 & 57,86 & 50,05 \\
\hline 2010 & L5 & 29/jun & 0,15 & 0,04 & 0 & 0,09 & 0,46 & 50,39 & 47,14 \\
\hline 2009 & L5 & 12/jul & 0,7 & 0,25 & 0,01 & 0 & 0,01 & 50,42 & 49,65 \\
\hline 2008 & L5 & $30 /$ nov & 6,53 & 0,05 & 8,84 & 0,96 & 16,28 & 56,42 & 126,49 \\
\hline 2006 & L5 & 05/ago & 1,52 & 4,23 & 1,16 & 0,67 & 0 & 53,94 & 55,63 \\
\hline 2005 & L5 & 01/ago & 0,94 & 2,57 & 1,16 & 0,01 & 0,03 & 49,84 & 48,03 \\
\hline 2004 & L5 & 31/ago & 0,37 & 0,93 & 0,53 & 0 & 0 & 56,59 & 69,99 \\
\hline 2001 & L7 & 03/nov & 5,42 & 1,72 & 3,57 & 5,89 & 10,49 & 61,41 & 117,11 \\
\hline 1999 & L5 & 02/ago & 0,06 & 0,05 & 0,01 & 0,18 & 0 & 50,21 & 57,4 \\
\hline 1997 & L5 & 27/jul & 1,46 & 0,98 & 4,85 & 0 & 0 & 48,11 & 56,78 \\
\hline 1995 & L5 & 10/out & 10,88 & 0,04 & 14,98 & 7,46 & 21,04 & 51,01 & 96,88 \\
\hline 1991 & L5 & 25/jun & 0 & 0 & 0 & 0 & 0 & 45,23 & 52 \\
\hline 1988 & L5 & 18/jul & 0,09 & 0,37 & 0,01 & 0 & 0 & 47,26 & 54,42 \\
\hline 1986 & L5 & 14/ago & 0 & 0 & 0 & 0 & 0 & 48,49 & 64,42 \\
\hline 1984 & L5 & 24/ago & 8,55 & 18,64 & 9,38 & 4,9 & 1,28 & 52,15 & 68,01 \\
\hline \multicolumn{10}{|c|}{$\begin{array}{l}\text { Sensores e câmeras: L8: LANDSAT } 8 \text { (OLI) - L7: LANDSAT } 7 \text { (ETM+) - L5: LANDSAT } 5 \text { (TM) - IRS- } \\
\text { P6: Indian Resource Sat (LISS3) }\end{array}$} \\
\hline
\end{tabular}

${ }^{6}$ Cobertura de nuvens: efeito meteorológico que pode ocultar áreas de desmatamento e dificultar o processamento digital a interpretação das imagens orbitais. 
Além das cenas listadas na Tabela 12 foram utilizados dados georreferenciados para validação das classificações como, por exemplo, as taxas anuais de desmatamento de 2000 a 2015 disponibilizados pelo PRODES-INPE (2016), e a qualificação do desmatamento em classes de uso e cobertura da terra para 2004, 2008, 2010, 2012 e 2014, disponíveis nos dados TERRACLASS (INPE-CRA, 2016).

\subsubsection{Pré-processamento das imagens}

Pré-processamento digital das imagens é o processo definido como o conjunto de técnicas e métodos que permitem a correção dos erros inerentes ao processo de aquisição dos dados (NOVO, 2008). Estes erros podem ser inerentes à operação do satélite (radiométricas), às condições ambientais (efeitos atmosféricos), e à curvatura da terra (erros geométricos). Atualmente, a maioria dos dados orbitais é distribuída pelos provedores com estes erros corrigidos, mas algumas correções pontuais foram necessárias neste estudo.

\subsubsection{Correção atmosférica das imagens}

Toda imagem obtida por sensoriamento remoto tem seus números digitais influenciados por fatores ambientais como a hora da varredura, o ângulo de incidência solar sobre a superfície terrestre, a umidade da cobertura vegetal e a presença de nuvens e particulados na atmosfera. Estes fatores ambientais condicionam e, até mesmo, comprometem o uso de uma imagem orbital.

A interação da energia solar com outras fontes de energia (e o ambiente) faz ela se difundir em diferentes trajetórias, podendo trazer ruídos ao processo de sensoriamento remoto (Figura 19). Algoritmos e aplicativos podem filtrar estas trajetórias substituindo, por exemplo, os valores de refletância do topo da atmosfera (influenciado por fenômenos meteorológicos como nuvens e brumas) pelos valores de refletância da superfície terrestre com base em variáveis radiométricas. 


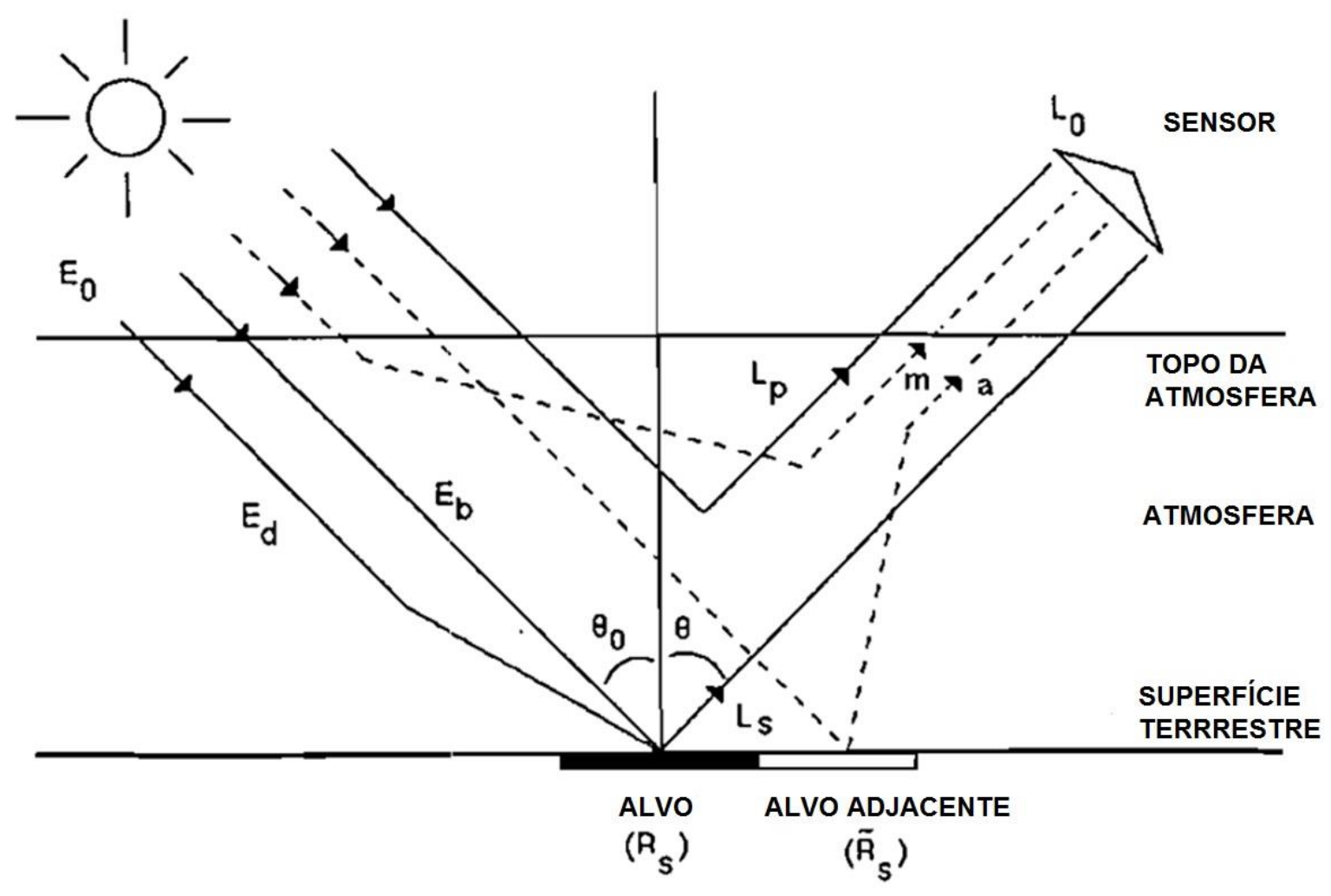

Figura 19 - A interação da energia solar com o ambiente

Onde as linhas sólidas referem-se aos componentes da radiação consideradas no modelo:

Eo - irradiância solar;

$E b$ - radiação solar direta, incidente na superfície;

$E d$ - radiação solar difusa, incidente na superfície (claraboia);

$L p$ - trajetória da radiação;

$L s$ - irradiação proveniente da superfície alvo da reflectância $R s$;

$R s$ - alvo e $\bar{R} s$ - alvo adjacente.

Por outro lado, as linhas tracejadas referem-se às componentes da radiação negligenciadas no modelo: a -refere-se ao efeito devido ao alvo adjacente com reflectância $\bar{R} s$;

$m$ - refere-se a dispersão múltipla na atmosfera;

0 e 0 o referem-se, respectivamente, ao ângulo de elevação solar e ao ângulo zenital.

Fonte: Adaptado de Gilabert, Conese e Maselli (1994).

Esta filtragem da trajetória da luz é chamada de correção atmosférica. Quando o usuário pretende utilizar uma imagem orbital apenas para efeito ilustrativo é desnecessária a aplicação da correção atmosférica. No entanto, quando esta mesma imagem será objeto de análise estatística em estudo multitemporal a correção é necessária como meio para garantir a correspondência com outras imagens de um mesmo sensor, mas de diferentes períodos. 
A caracterização espectral de um objeto é inviável sem a correção atmosférica, pois o valor do número digital de uma imagem bruta não está no mesmo intervalo de valores escala de outro número digital em uma imagem corrigida. Isso traz como consequência a impossibilidade de comparação entre números digitais de duas diferentes imagens de um mesmo sensor, bem como de sensores diferentes (PONZONI, SHIMABUKURO, 2010).

Segundo Novo (2008), os aplicativos que filtram estas trajetórias da luz são importantes para três casos específicos:

1) quando o usuário quer recuperar o valor da grandeza radiométrica medida, ou seja, quando ele deseja conhecer a refletância, emitância ou retro espalhamento do objeto em estudo;

2) quando o usuário precisa utilizar os algoritmos baseados em operações aritméticas entre bandas;

3) quando o usuário quer comparar imagens de diferentes datas em termos das propriedades dos objetos da cena.

A disponibilização gratuita de imagens LANDSAT incrementou a demanda por algoritmos de correção atmosférica robusta e eficiente aplicável em grandes volumes de dados LANDSAT (JU et al., 2012). Os autores enumeram algumas técnicas para correção atmosférica das imagens LANDSAT baseadas na subtração de pixels escuros (Dark-Object Subtraction - DOS) de Chavez et al. (1988), e na transferência radiativa como o MODTRAN (BERK et al., 1989) e a Second Simulation of a Satellite Signal in the Solar Spectrum (6S) de Vermote et al. (1997).

Os métodos baseados em modelos DOS caracterizam-se pela fácil aplicação, pois dependem de metadados da própria imagem, porém a correção atmosférica considera apenas o espalhamento da atmosfera e ignora completamente a absorção dos constituintes (PONZONI; SHIMABUKURO, 2010). Em contraste, os métodos baseados na transferência radiativa não possuem estas restrições e são amigáveis ao processamento de grande volume de dados, embora necessitem dados espaciais e temporais para a caracterização atmosférica (VERMOTE et al., 2002).

Para melhor entendimento de um modelo de transferência radiativa, a refletância de uma superfície qualquer (superfície lambertiana uniforme) pode ser compreendida pela equação simplificada de Gilabert, Conese e Maselli (1994): 


$$
R s(\lambda)=\frac{\kappa \pi L s(\lambda)}{\operatorname{Eg}(\lambda) \cos \theta o}
$$

\section{Onde}

$R s(\lambda)=$ é a refletância da superfície no comprimento de onda $\lambda$ (dimensionável);

$L s(\lambda)=$ é a irradiância da superfície $\left(\mathrm{Wm}^{-2} \mu \mathrm{m}^{-1} \mathrm{sr}^{-1}\right)$;

$\operatorname{Eg}(\lambda)=$ é a irradiância solar global na superfície horizontal $\left(W m-{ }^{2} \mu^{-1}\right)$;

$\theta o=$ é o ângulo do zênite solar; e

$K=$ considera a mudança na distância Terra-Sol tendo em conta a excentricidade da órbita da Terra e o dia juliano.

Com base no modelo de transferência radiativa 6S, pesquisadores do Space Flight Center Goddard (NASA) e da Universidade de Maryland desenvolveram o algoritmo Landsat Ecosystem Disturbance Adaptive Processing System (LEDAPS). Originalmente desenvolvido apenas para produzir imagens Top of Atmosphere (TOA) para imagens LANDSAT (5 TM) e LANDSAT 7 (ETM+). A partir de 2011, o LEDAPS foi adaptado para gerar imagens Surface Reflectance (SR), e mais recentemente sendo aplicado também em imagens LANDSAT 8 (OLI).

Segundo a USGS (2016) o algoritmo LEDAPS constitui-se de seis módulos que, resumidamente, executam três atividades essenciais:

1) converter o número digital da imagem bruta em correção de refletância topo de atmosfera (TOA);

2) detectar pixels característicos de nuvens e sombras na imagem TOA;

3) criar a imagem de correção de refletância à superfície terrestre (SR) a partir da imagem TOA e de dados auxiliares (metadados e bandas da imagem no formato GEOTIFF, dados climáticos e modelo de elevação do terreno).

A diferença fundamental entre uma imagem com correção de refletância ao topo de atmosfera com a correção de refletância à superfície é que, esta última, simula a propagação da radiação na superfície terrestre caso não houvesse atmosfera (VERMOTE et al., 2002). Um algoritmo com esta finalidade corrige os efeitos de dispersão de gases e aerossóis, bem como os efeitos adjacentes causados por mudanças no uso da terra (Figura 20). 

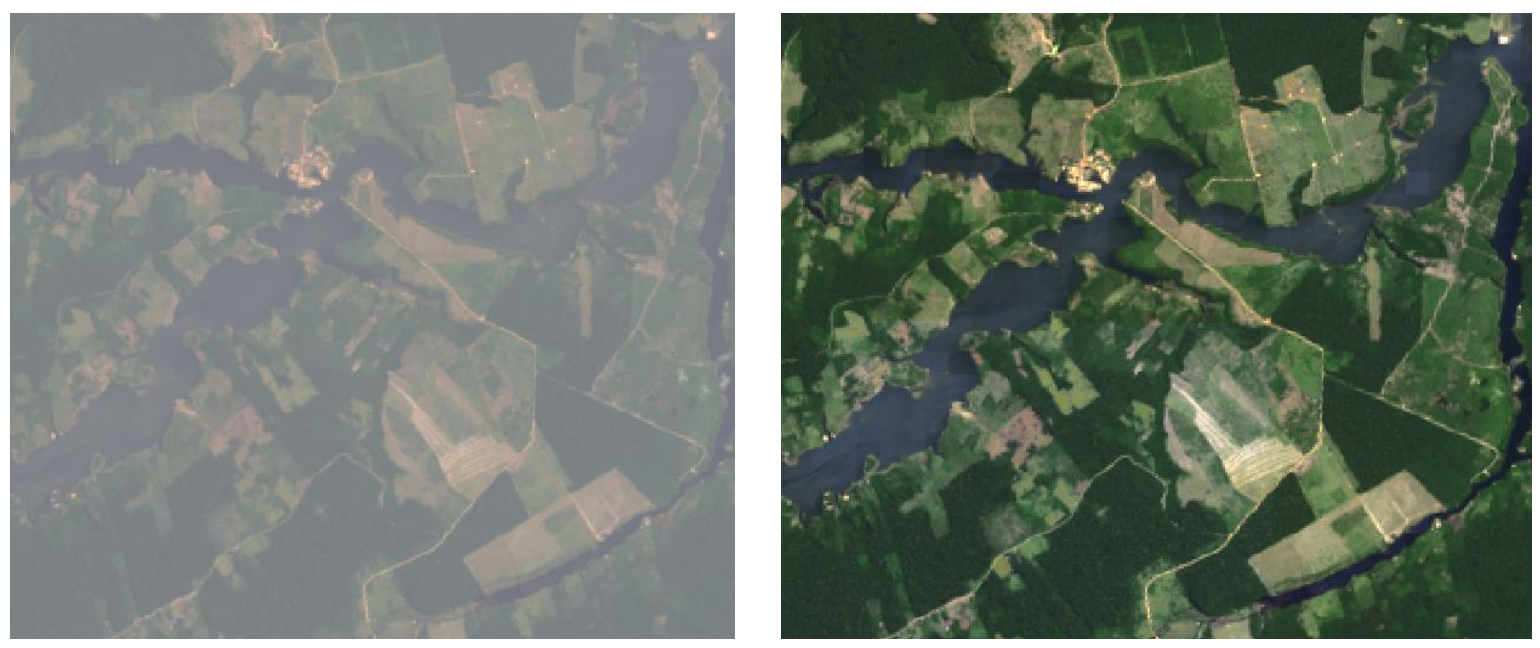

Figura 20 - Exemplo de correção atmosférica LEDAPS

Imagem LANDSAT 8. Na esquerda uma composição colorida (bandas r3, g2, b1) com correção topo de atmosfera (TOA); na direita uma imagem "superfície de refletância" corrigida com LEDAPS. Localização: $2^{\circ} 55^{\prime} 37^{\prime \prime}$ S e 54 $4^{\circ} 28^{\prime} 59^{\prime \prime}$ W, desembocadura do rio Moju no rio Curuá-Una.

Dada a natureza deste estudo e a importância da comparação entre imagens de diferentes períodos e de diferentes sensores um mesmo sensor, operou-se apenas com imagens com correção de refletância à superfície, processadas no algoritmo LEDAPS, disponíveis no catálogo EARTHEXPLORER (USGS-EROS, 2016. No entanto, o algoritmo LEDAPS é compatível apenas com os sensores MODIS, AVNIR e LANDSAT, obrigando a aplicar outro algoritmo de correção atmosférica baseado em MODTRAN para a única imagem do sensor IRS-P6 (LISS3) utilizada neste estudo.

Para a correção atmosférica da imagem do sensor IRS-P6 (LISS3) foi utilizado o algoritmo Fast Line-of-sight Atmospheric Analysis of Spectral Hypercubes (FLAASH) do aplicativo de processamento digital de imagens ENVI (EXILIS, 2014). O FLAASH (ADLER-GOLDEN et al., 1999) é um algoritmo baseado no modelo de transferência radiativa MODTRAN. Para a correção da imagem datada de $1^{\circ}$ de agosto de 2012 foi necessário incorporar aos dados da imagem IRS-P6 as características espectrais listadas em Pandya, Murali e Kirankumar (2013) e descritos na Tabela 14. 
Tabela 13 - Parâmetros para correção atmosférica da imagem IRS-P6

\begin{tabular}{|c|c|c|}
\hline \multicolumn{3}{|c|}{ Parâmetros espectrais } \\
\hline Banda & Comprimento de onda & FWHM (Largura à meia altura) \\
\hline 1 & 0,5611 & 0,5615 \\
\hline 2 & 0,6548 & 0,6550 \\
\hline 3 & 0,8118 & 0,8195 \\
\hline 4 & 1,6291 & 1,6270 \\
\hline \multicolumn{3}{|c|}{ Dados do sensor e da varredura da imagem } \\
\hline \multicolumn{2}{|c|}{ Latitude central: $2^{\circ} 57^{\prime} 29,07^{\prime \prime} \mathrm{S}$} & Altitude do sensor: 817 km \\
\hline \multicolumn{2}{|c|}{ Longitude central: $54^{\circ} 41^{\prime} 46,67^{\prime \prime} \mathrm{W}$} & Elevação da superfície: 0,0 km \\
\hline \multicolumn{2}{|c|}{ Data da varredura: 01/08/2012 } & Visibilidade inicial: 40 km \\
\hline \multicolumn{2}{|c|}{ Hora da varredura: 14:02:56 } & Multiplicador da coluna de água: 1 \\
\hline \multicolumn{3}{|c|}{$\begin{array}{c}\text { Bandas indicadas para condições de recuperação de aerossol } \\
\text { (Aerossol retrieval conditions) } 2 \text { Bands K-T }\end{array}$} \\
\hline \multicolumn{2}{|c|}{ KT Upper Channel: SWIR } & KT Lower Channel: Red \\
\hline
\end{tabular}

Fonte: Adaptado de ENVI (EXILIS, 2014) e Pandya, Murali e Kirankumar (2013).

\subsubsection{Correção geométrica das imagens}

Existem mais fontes de distorções geométricas que distorções radiométricas em imagens de sensoriamento remoto (NOVO, 2008). A correção geométrica visa justamente recuperar a qualidade geométrica da cena, de tal modo que os dados possuam característica de escala e projeção própria de mapas (MATHER, 1987). Existem três tipos de correção geométrica: a retificação, a ortorretificação e o georreferenciamento.

Dentre as principais fontes de erros geométricos, Novo (2008) cita:

1) o movimento de rotação da Terra durante o processo de aquisição de imagens;

2) a velocidade de "varredura" finita;

3) o amplo campo de visada de alguns sensores;

4) a curvatura da Terra;

5) variações na posição da plataforma de aquisição (altura, velocidade, direção, entre outros);

6) efeitos panorâmicos relacionados à geometria da imagem.

Com o objetivo de reduzir possíveis erros geométricos na sobreposição entre imagens de diferentes datas, todas as cenas LANDSAT (sensores L5, L7, L8) deste estudo foram coletadas de um mesmo repositório de dados no catálogo 
EARTHEXPLORER (USGS, 2016). Estas imagens são retificadas e processadas no aplicativo LPGS, tendo como base as cenas de referência LANDSAT conhecidas como GLS (Global Land Survey), também produzidas pela USGS e NASA, as quais ortorretificadas utilizam o chamado padrão de correção de terreno LT1.

As imagens GLS são ortorretificadas com base em pontos de controle no solo (GCP) e em modelo digital de elevação (DEM), cobrindo cinco diferentes épocas: 1975, 1990, 2000, 2005, 2010 e, conforme as informações de referência do catálogo EARTHEXPLORER (USGS, 2016), estas cenas são processadas no formato de dados GEOTIFF, reexibidas pelo método convolução cúbica (ou interpolação cúbica conforme NOVO, 2008) e projetadas cartograficamente para o sistema de coordenadas plano retangular UTM, Zona 21 Sul, e Datum ${ }^{7}$ WGS-1984.

O sistema de coordenadas plano retangular UTM, e a referência horizontal no Datum WGS-1984 foram mantidos para evitar deformações geométricas e radiométricas nas imagens. Apenas na imagem IRS-P6, coletada no catálogo de imagens de satélite do INPE, foi necessária retificação sobre uma imagem LANDSAT- 8, de 14 de agosto de 2015. Assim, no aplicativo de processamento de imagens ENVI (EXILIS, 2014) foram coletados cerca de 200 pontos de controle (erro médio máximo de 0.5) para o ajuste e projeção da imagem de 2012 para as mesmas coordenadas da imagem de 2015.

\subsubsection{Operações de ajuste espectral, radiométrico e geométrico nas imagens.}

Para uma adequada análise das imagens orbitais, três operações de baixa complexidade técnica foram essenciais durante a fase de pré-processamento: o empilhamento de bandas, a conversão radiométrica de formato de arquivo, e o recorte da imagem para remoção valores NO DATA (sem dado ou nulo). As três operações de ajuste foram realizadas utilizando o aplicativo ENVI (EXILIS, 2014).

O empilhamento de bandas (layer stacking) é a primeira etapa de processamento de imagem após sua aquisição, antecedendo a correção atmosférica e a correção geométrica. A operação resume-se a compilação das bandas de uma imagem num único arquivo, sem comprometimento dos valores individuais de cada faixa espectral. Conforme Huang et al. (2008), o empilhamento é necessário para o

\footnotetext{
7 Datum: referencial na superfície terrestre para cálculos cartográficos, onde há o encontro entre a superfície de um elipsoide, um geoide e a própria superfície terrestre.
} 
grupo de técnicas que tratam a detecção de mudanças no uso e cobertura da terra como um problema classificação multitemporal, sendo sucedido por algoritmos de agrupamento ou machine-learning ${ }^{8}$ tanto para as classes de uso e cobertura como para as classes relacionadas às mudanças.

Como padrão, o ENVI (EXILIS, 2014) empilha os valores de uma faixa espectral ordenados numa sequência simples chamada Band Sequential (BSQ), onde cada linha de dados é seguida imediatamente pela próxima linha de dados. Quando as imagens são empilhadas e transformadas numa imagem multiespectral ${ }^{9}$, a sequência de valores pode ser ordenada no formato Band-interleaved-by-pixel (BIP) ou no formato Band-interleaved-by-line (BIL).

$O$ formato de sequência BIP armazena o primeiro pixel de todas as bandas em ordem sequencial numa primeira linha, depois o segundo pixel de cada banda e assim por diante. $\mathrm{O}$ formato BIL armazena os valores da primeira linha da primeira banda, depois os valores da primeira linha da segunda banda, intercalando até o último valor da última banda. Através da experiência empírica verificou-se que o formato BIL é mais adequado para posterior análise no aplicativo ECOGNITION (TRIMBLE, 2016), após o empilhamento, a correção geométrica e a correção atmosférica.

Todas as imagens utilizadas neste estudo são quantizadas em 16 bits ${ }^{10}$. Segundo Novo (2008), com 16 bits é possível diferenciar até $65.536\left(2^{16}\right)$ níveis de brilho cinza, também chamados de níveis digitais ou níveis de cinza. Quanto maior for a capacidade do sensor de distinguir diferenças de intensidade de sinal, maior será sua resolução radiométrica.

A última operação de pré-processamento da imagem foi o recorte da mesma e a remoção dos valores NULL (nulos ou sem dados) externos à própria imagem e constituintes da margem. Através da experiência empírica constatou-se que a análise de uma imagem no aplicativo ECOGNITION (TRIMBLE, 2016) é comprometida pelos valores NULL pois eles interferem na distribuição dos valores de atributos de uma imagem, principalmente os valores de textura.

A solução encontrada, portanto, foi o recorte da imagem de acordo com um retângulo envolvente que considerasse a área útil da imagem de satélite e toda a área

\footnotetext{
${ }^{8}$ Machine-learning: aprendizagem estatística ou de máquina.

9 Imagem multiespectral: múltiplas imagens obtidas numa mesma varredura que cobrem as diferentes faixas (bandas) do espectro eletromagnético (NOVO, 2008).

${ }^{10}$ Bit: acrônimo de dígito binário.
} 
de estudo. Aplicado para todas as imagens analisadas. Outro benefício indireto desta operação é a redução no tempo de processamento e análise de cada imagem.

\subsubsection{Segmentação}

A primeira etapa na análise geográfica orientada a objetos é o processo de segmentação, que consiste na divisão da imagem em regiões ou objetos com características espectrais e espaciais similares (PIAZZA et al., 2016). O aplicativo ECOGNITION dispõe de algoritmos de segmentação que operam no conceito de agregação de regiões ou objetos (region growing).

Dentre os algoritmos para segmentação de imagens, Fu e Mui (1981) qualificam as categorias principais: Identificação de limiares de feição característica ou agrupamento (characteristic feature thresholding or clustering) conforme Huete et al. (1997); detecção de borda (Boundary detection) segundo Risso et al. (2009), e crescimento de região (Region growing) segundo Huete (1988).

Considerando a resolução espacial das imagens usadas neste trabalho (30 metros) foi selecionado o algoritmo de segmentação do tipo resolução múltipla (multiresolution segmentation). Ele consiste em agregar pixels ou objetos existentes, minimizando a heterogeneidade e maximizando a respectiva homogeneidade. $O$ algoritmo inicia com objetos simples da imagem, compostos por um único pixel, agregando-os repetidamente em pares, formando unidades maiores até que um limite de homogeneidade definido pelo usuário (parâmetro "escala") não seja excedido localmente (TRIMBLE, 2016).

Neste processo o algoritmo varre a imagem a partir de um pixel inicial à procura do vizinho que melhor se assemelha e poderá ser agregado. Em caso afirmativo, o novo objeto passa a ser a origem e o algoritmo procura outro vizinho semelhante. Sempre que o melhor ajuste ocorre, os objetos da imagem são agregados. O processo continua em diversas iterações, até não ser mais possível nenhuma agregação, considerando os limites de homogeneidade determinados pelo usuário.

Não há na literatura, valores predefinidos para os parâmetros configuráveis para o tipo de segmentação selecionada (escala, forma e compacidade), no entanto Piazza et al (2016) lembram que o parâmetro de escala define o tamanho de um objeto; em outras palavras, baixo valor nos parâmetros de escala criará muitos segmentos, enquanto valores altos nos parâmetros de escala resultarão em pouco e grandes segmentos. Assim, testes foram realizados até chegar-se ao valor 50 como 
escala para o tamanho dos segmentos. Para a composição do critério de homogeneidade dos segmentos adotou-se o valor 0,2 para a forma dos segmentos e, para a compacidade dos segmentos, adotou-se o valor 0,5.

Enquanto a homogeneidade refere-se à informação espectral de um pixel e dos pixels vizinhos a ele, a compacidade refere-se à geometria. Segundo Piazza et al. (2016), valores altos de compacidade levam à geração de objetos geométricos e retos, enquanto valores baixos permitem a geração de objetos assimétricos e com diferentes características espectrais.

No livro de referência do aplicativo ECOGNITION (TRIMBLE, 2016) não há especificação sobre qual unidade de medida estão estes valores e se há valores mínimos ou máximos, no entanto está indicado que há uma relação direta com a resolução espacial (em metros) do pixel da imagem. Assim podemos assumir a escala como 50 metros (um pouco maior que os 30 metros de resolução espacial das imagens utilizadas), 20 centímetros para a forma e 50 centímetros para a compacidade.

\subsubsection{Atributos espectrais e de textura incorporados à segmentação}

Para cada objeto reconhecido na imagem através do algoritmo de segmentação, atributos com diferentes propriedades espectrais, de textura, geométricas e topológicas podem ser consultados ou customizados como é caso dos índices de vegetação. Neste estudo quinze destes atributos foram definidos para posterior análise estatística.

Características espectrais de textura e de contexto compõem o três elementospadrão usados na interpretação humana em fotografias coloridas (HARALICK; SHANMUGAN; DINSTEIN., 1973). As características espectrais descrevem a média de variação tonal em diversas bandas do espectro eletromagnético, ao passo que as características de textura contêm informações da distribuição espacial das variações tonais em uma banda. As características contextuais possuem informações derivadas de blocos de dados pictóricos em relação à vizinhança da área analisada.

Tonalidade e textura devem ser consideradas em conjunto, apesar de uma propriedade poder ocultar a outra durante a análise de uma imagem orbital. Por exemplo, quando um pixel um recorte da imagem possui pouca variação dos tons de cinza, a tonalidade é dominante. Por outro lado, se em um outro trecho houver maior 
variação dos tons de cinza, a textura é dominante. Para essa distinção é fundamental compreender a dimensão da imagem e dos objetos nela a serem analisados.

Três atributos relacionados a propriedades de uma imagem multiespectral foram selecionados para a análise estatística: a média, o brilho e a máxima diferença entre as bandas que compõem a imagem. Os atributos relacionados à textura também correspondem a valores médios multiespectrais, e os índices de vegetação (item 5.3.4.2) foram obtidos através da razão entre diferentes faixas espectrais (bandas).

A aplicação do conceito de textura em imagens obtidas por sensoriamento remoto está em desenvolvimento desde o surgimento do algoritmo Gray-Level Co- occurrence Matrix - GLCM (HARALICK; SHANMUGAN; DINSTEIN,1973), implementado em algumas ferramentas de processamento de imagens para a medição de textura, que é uma tabulação da frequência de combinações diferentes de níveis de cinza dos pixels em uma cena (TRIMBLE, 2016, p. 320).

Com base no livro de referência do ECOGNITION (TRIMBLE, 2016) são descritas algumas das propriedades do GLCM utilizadas como critérios de classificação no presente trabalho, apresentados na sequência.

- Média GLCM. O valor médio do GLCM é calculado a partir do valor do pixel multiplicado pela frequência de sua ocorrência em relação a um determinado valor de pixel vizinho.

- Homogeneidade. Se o objeto da imagem é considerado localmente homogêneo, o valor dos pixels deve ser alto se o valor do GLCM se concentra ao longo da diagonal. A homogeneidade pondera os valores pelo inverso do peso do contraste, diminuindo exponencialmente de acordo com a distância em relação à diagonal. Apresenta valores com variação entre 0 e 1, onde 1 é uma superfície totalmente homogênea como sombra ou nuvem.

- Contraste. Oposto da homogeneidade, o contraste mede a variação da quantidade de variações locais em uma imagem; os valores de contraste crescem exponencialmente com o incremento de objetos em uma imagem.

- Entropia. A entropia é considerada alta se os elementos do GLCM são distribuídos equitativamente. É considerada baixa se os valores dos elementos estão entre 0 e 1. 
- $\quad$ Angular Second Moment (ASM). É uma medida de homogeneidade dada pela soma dos quadrados dos valores de entrada numa imagem. Assim como na homogeneidade, a ASM apresenta variação entre 0 e 1, onde 1 é uma superfície totalmente homogênea como sombra ou nuvem.

- Desvio padrão. Mede a dispersão dos valores em relação à média do GLCM. Corresponde ao desvio padrão do GLCM, com referência aos pixels vizinhos, não se tratando de desvio padrão simples dos níveis de cinza da imagem original. O cálculo do desvio padrão utilizando i ou j gera o mesmo resultado, uma vez que o GLCM é simétrico. É uma medida similar ao contraste e a dissimilaridade.

- Correlação. Mede a dependência linear dos níveis de cinza em relação aos pixels vizinhos.

- Dissimilaridade. Medida similar ao contraste, que aumenta de forma linear. O valor é alto se a região possui contraste alto.

\subsubsection{1 Índices de vegetação incorporados como atributos aos segmentos}

Para caracterização dos segmentos foram utilizados os atributos espectrais (brilho e média das bandas) e atributos de textura (GLCM), e quatro índices de vegetação. Estes índices são construídos a partir da razão dos valores de célula entre duas faixas espectrais, pois quando combinadas oferecem novos parâmetros de análise, em relação à análise isolada de cada uma das faixas do espectro eletromagnético que compõem uma imagem.

Nos últimos quarenta anos, com a disseminação das aplicações ambientais em Sensoriamento Remoto, muitos índices de vegetação foram criados e aperfeiçoados (associados às vezes a outros parâmetros físicos), em busca de bons resultados para determinar o vigor e a saúde da vegetação, ou para uma melhor distinção entre vegetação, solo e água. Aqui utilizamos apenas alguns dos índices mais populares que não exigem, necessariamente, o apoio de índices físicos não disponíveis para a área de estudo.

- $\quad$ Normalized Difference Vegetation Index (NDVI). É o índice de vegetação de uso mais disseminado e com maior quantidade de aplicações na literatura. Proposto por Rouse et al. (1973), corresponde à razão entre a diferença da refletância na região do infravermelho próximo (NIR) e do vermelho e pela soma 
dessas mesmas bandas. Os valores variam de -1 a 1 , sendo que quanto mais próximo de 1, mais densa é a vegetação e zero indica ausência de vegetação. É muito utilizado no monitoramento da saúde da vegetação (a vegetação saudável absorve a maior parte da luz visível que a atinge e reflete grande parte da luz infravermelha, já a vegetação doente reflete mais a luz visível e menos a luz do infravermelho próximo):

$$
N D V I=\frac{(N I R-R e d)}{(N I R+R e d)}
$$

Onde NIR é o valor da faixa do infravermelho próximo para uma célula (pixel), e RED é o valor da faixa do vermelho para uma célula.

- $\quad$ Soil-adjusted Vegetation Index (SAVI). Este índice, proposto por Huete (1988), aplica-se à distinção da cobertura vegetal pouco densa, sendo uma modificação do NDVI para corrigir a influência do brilho em áreas de solo exposto, com pouca vegetação:

$$
S A V I=\frac{(N I R-R e d)}{(N I R+R e d+L)} *(1+L)
$$

Onde L é o fator de ajuste para o substrato do dossel (para áreas onde a cobertura vegetal é muito baixa é sugerido 1, para cobertura vegetal intermediária é sugerido o valor 0,5 e, para vegetação densa, valor 0,25 (RODRIGUES, 2013). Seguindo a sugestão do autor foi utilizado o fator 0,5 , correspondente à cobertura vegetal intermediária, devido à fragmentação da paisagem na área de estudo;

O SAVI foi concebido originalmente para aplicações em imagens com correção de refletância, do tipo "topo de atmosfera" (Top of Atmosphere - TOA), que se resume na calibração de uma imagem bruta a partir do sensor em órbita, porém com contribuição de nuvens e gases atmosféricos em seus valores. Dentre as imagens com este tipo de correção atmosférica enquadram-se os sensores MODIS, LANDSAT e AVHRR. Nestas imagens o intervalor de valores do SAVI varia entre -1 e 1. 
Como justificado anteriormente no item 5.3.3.1, neste estudo foram utilizadas imagens com correção de refletância do tipo "superfície de refletância" (Surface Reflectance - SR), que são imagens derivadas de imagens TOA e refere-se aos valores de refletância da superfície terrestre, sem a contribuição de nuvens e gases atmosféricos (exceto quando visíveis). O uso de imagens SR acarreta consequências em índices de vegetação, com fatores de ajuste como o SAVI, para os quais o intervalo varia não mais entre -1 e 1, mas sim entre -10 e 10, de acordo com a USGS (2016, p.14).

- $\quad$ Normalized Difference Water Index (NDWI). O NDWI foi proposto por Gao (1996) como um índice empregado para identificação de umidade e superfícies aquáticas, com base no emprego da razão entre a diferença do verde e do infravermelho próximo (NIR) e a soma dessas mesmas bandas:

$$
N D W I=\frac{(\text { Green }-N I R)}{(\text { Green }+N I R)}
$$

- $\quad$ Normalized Difference Moisture Index (NDMI). O índice espectral de vegetação calculado pela razão das bandas infravermelho próximo (NIR) e do infravermelho médio (SWIR) tem sido largamente utilizado para indicar a umidade da vegetação (Jl et al., 2011), criando ambiguidade entre termos como NDWI (GAO, 1996), NDMI (WILSON; SADER, 2002; USGS, 2016), NDII (HUNT JR.; ROCK, 1989), NBR (KEY; BENSON, 1999), entre outros ${ }^{11 .}$ Para tirar o efeito ambíguo foi adotado neste estudo o termo NDMI (WILSON; SADER, 2002; USGS, 2016), este índice ajudou a diferenciar fisionomias de variados ou nenhum grau de umidade, como solo nu, e os estágios de sucessão florestal. Para estimar a umidade na vegetação calcula-se a razão entre a diferença das bandas do infravermelho próximo (NIR) e do infravermelho médio (SWIR) e a soma dessas mesmas bandas:

$$
N D M I=\frac{(N I R-S W I R)}{(N I R+S W I R)}
$$

11 Veja a lista de abreviaturas para consultar o respectivo significado. 
Além dos índices de vegetação, foi utilizada a média dos valores espectrais para todas as bandas, com o objetivo de facilitar a comparação e os estudos de deteç̧ão de mudanças nos demais anos e diminuir a quantidade de dados espectrais, também porque há maior variação dos valores dos níveis digitais de cada banda individualmente em cada ano, para a mesma região, e menor variação se forem comparadas as médias de todas as bandas entre os anos analisados.

\subsubsection{Seleção de amostras de treinamento}

Após o processo de segmentação das imagens, amostras de treinamento foram selecionadas para cada classe contemplada definida para a classificação, usando como apoio o material fotográfico relacionado no item 5.2.4 e as imagens datadas de 2012 (IRS-P6) e 2015 (LANDSAT 8) como referência visual para coleta de amostras em todas as outras imagens, pois são as imagens mais recentes com nenhuma (período 2012) e pouca (período 2015) cobertura de nuvem e sombra.

Tabela 14 - Quantidade de segmentos criados e segmentados amostrados para cada período de classificação

\begin{tabular}{|c|c|c|c|}
\hline Período & Quantidade de segmentos & $\begin{array}{c}\text { Quantidade de segmentos } \\
\text { amostrados }\end{array}$ & $\%$ \\
\hline 1984 & 113.696 & 1.480 & 1,30 \\
\hline 1986 & 238.821 & 1.806 & 0,76 \\
\hline 1988 & 66.942 & 666 & 0,99 \\
\hline 1991 & 100.305 & 2.722 & 2,71 \\
\hline 1995 & 111.399 & 3.208 & 2,88 \\
\hline 1997 & 84.615 & 1.761 & 2,08 \\
\hline 1999 & 70.799 & 2.506 & 3,54 \\
\hline 2001 & 133.399 & 2.590 & 1,94 \\
\hline 2004 & 69.815 & 1.794 & 2,57 \\
\hline 2005 & 95.368 & 2.359 & 2,47 \\
\hline 2008 & 116.234 & 3.390 & 2,92 \\
\hline 2009 & 136.066 & 2.464 & 1,81 \\
\hline 2010 & 78.557 & 1.790 & 2,28 \\
\hline 2012 & 88.598 & 1.690 & 1,91 \\
\hline 2013 & 197.172 & 5.653 & 2,87 \\
\hline 2014 & 121.660 & 1.381 & 1,14 \\
\hline 2015 & 194.915 & 2.373 & 1,22 \\
\hline 2016 & 97.848 & 2.099 & 2,15 \\
\hline Observação Imagens & 149.236 & 1.756 & 1,18 \\
\hline
\end{tabular}


As amostras de treinamento classificadas foram exportadas com os respectivos atributos espectrais, de textura e os índices de vegetação, para a realização da análise estatística no aplicativo de mineração de dados WEKA (FRANK; HALL;WITTEN, 2016).

\subsubsection{Análise estatística dos segmentos}

Independente do algoritmo de segmentação selecionado, todos os objetos resultantes possuem atributos espectrais e geográficos relacionados à textura, geometria, forma e padrão, além dos índices de vegetação calculados (NDVI, SAVI, NDWI, NDMI) para cada objeto geográfico.

Para correlacionar estes atributos na determinação de cada classe, foi necessário submete-los a análise estatística empregando o aplicativo de mineração de dados WEKA (FRANK, HALL, WITTEN, 2016), e o ARCGIS (ESRI, 2015) para verificação visual da consistência de agrupamentos e relações. A Tabela 15 apresenta os atributos mais significativos para construção da chave de classificação dos estágios de sucessão de floresta secundária.

O WEKA é um aplicativo de código aberto para mineração de dados e bem documentado em literatura recente (CORDEIRO; ROSSETTI, 2015; DRONOVA et al., 2015; HUSSAIN et al., 2013; PIAZZA et al., 2016; STOJANOVA et al., 2010). Baseado em algoritmos de machine-learning contém instrumentos para pré-processamento, classificação e análise por agrupamentos de dados tabulares.

O WEKA dispõe de algoritmos testados e analisados com os atributos dos segmentos tendo em vista sua aplicação ao estudo em questão, com o objetivo de produzir uma árvore que apresentasse a melhor confiabilidade, tamanho aceitável no número de nós e folhas, e que não demandasse muito tempo para implementação no aplicativo utilizado para a segmentação e classificação. Dentre os algoritmos utilizados, o que mais atendeu a esses critérios foi o SIMPLECART (BREIMAN et al., 1984).

O SIMPLECART é um algoritmo desenvolvido na linguagem Java baseado na Árvore de Classificação e Regressão (CART) de Breiman et al. (1984), sendo empregado em análise exploratória e previsões. Utiliza dados pré-classificados com base em observações, como ponto de partida para a construção da árvore de decisão (KALMEG, 2015). Como dados pré-classificados foram utilizadas as amostras de treinamento coletadas para cada período analisado da Tabela 14 apresentada anteriormente. 
Tabela 15 - Valores limiares usados na construção da árvore de decisão

\begin{tabular}{|c|c|c|c|c|c|c|c|c|c|c|c|c|c|c|c|}
\hline Categorias & & 1 & 2 & 3 & 4 & 5 & 6 & 7 & 8 & 9 & 10 & 11 & 12 & 13 & 14 \\
\hline Massas d'água & $\begin{array}{l}\text { Min } \\
\text { Max }\end{array}$ & $\begin{array}{l}117,63942 \\
157,00000\end{array}$ & $\begin{array}{l}0,00221 \\
0,23698\end{array}$ & $\begin{array}{l}582,15369 \\
6840,5625\end{array}$ & $\begin{array}{l}4,10477 \\
8,82256\end{array}$ & $\begin{array}{l}27,71618 \\
58,47465\end{array}$ & $\begin{array}{l}0,02456 \\
0,84637\end{array}$ & $\begin{array}{l}14,15174 \\
70,58333\end{array}$ & $\begin{array}{l}0,00021 \\
0,01750\end{array}$ & $\begin{array}{l}-0,76970 \\
0,40884\end{array}$ & $\begin{array}{l}0,12072 \\
0,51865\end{array}$ & $\begin{array}{l}-0,27748 \\
1,75892\end{array}$ & $\begin{array}{c}117,50231 \\
1148,75\end{array}$ & $\begin{array}{l}128,58078 \\
1287,8194\end{array}$ & $\begin{array}{l}0,73742 \\
2,88499\end{array}$ \\
\hline Área alagada & $\begin{array}{l}\text { Min } \\
\text { Max }\end{array}$ & $\begin{array}{l}112,37387 \\
143,04196\end{array}$ & $\begin{array}{l}0,00071 \\
0,07531\end{array}$ & $\begin{array}{l}264,03604 \\
10304,475\end{array}$ & $\begin{array}{l}3,78827 \\
8,16177\end{array}$ & $\begin{array}{l}16,05825 \\
73,98194\end{array}$ & $\begin{array}{l}0,12906 \\
0,86097\end{array}$ & $\begin{array}{l}12,21254 \\
93,12500\end{array}$ & $\begin{array}{l}0,00036 \\
0,02563\end{array}$ & $\begin{array}{l}-0,73033 \\
-0,38757\end{array}$ & $\begin{array}{l}0,02135 \\
0,51615\end{array}$ & $\begin{array}{l}1,02513 \\
1,72921\end{array}$ & $\begin{array}{l}371,32688 \\
1511,3469\end{array}$ & $\begin{array}{l}400,51130 \\
1666,2441\end{array}$ & $\begin{array}{l}1,29481 \\
2,79841\end{array}$ \\
\hline Nuvem & $\begin{array}{l}\text { Min } \\
\text { Max }\end{array}$ & $\begin{array}{c}94,11875 \\
142,82292\end{array}$ & $\begin{array}{l}0,00115 \\
0,03129\end{array}$ & $\begin{array}{l}2077,8969 \\
11526,729\end{array}$ & $\begin{array}{l}3,75749 \\
7,24569\end{array}$ & $\begin{array}{l}40,84411 \\
79,94813\end{array}$ & $\begin{array}{l}0,14938 \\
0,73029\end{array}$ & $\begin{array}{l}37,62399 \\
94,47917\end{array}$ & $\begin{array}{l}0,00078 \\
0,02604\end{array}$ & $\begin{array}{l}-0,43403 \\
-0,05317\end{array}$ & $\begin{array}{l}0,01232 \\
0,16326\end{array}$ & $\begin{array}{l}0,56648 \\
1,14483\end{array}$ & $\begin{array}{l}1923,3901 \\
7578,7162\end{array}$ & $\begin{array}{l}2040,4167 \\
7718,2139\end{array}$ & $\begin{array}{l}0,24825 \\
1,22620\end{array}$ \\
\hline Pastagem e campos & $\begin{array}{l}\text { Min } \\
\text { Max }\end{array}$ & $\begin{array}{l}112,02500 \\
138,31301\end{array}$ & $\begin{array}{l}0,00081 \\
0,14428\end{array}$ & $\begin{array}{l}445,94771 \\
3103,4372\end{array}$ & $\begin{array}{l}3,94227 \\
7,99598\end{array}$ & $\begin{array}{c}9,12706 \\
46,91597\end{array}$ & $\begin{array}{l}0,17605 \\
0,90635\end{array}$ & $\begin{array}{c}7,85161 \\
46,55276\end{array}$ & $\begin{array}{l}0,00027 \\
0,00496\end{array}$ & $\begin{array}{l}-0,70633 \\
-0,57500\end{array}$ & $\begin{array}{l}-0,10975 \\
0,49545\end{array}$ & $\begin{array}{l}1,09304 \\
1,83569\end{array}$ & $\begin{array}{l}978,39113 \\
1540,5086\end{array}$ & $\begin{array}{l}1101,1009 \\
1719,0467\end{array}$ & $\begin{array}{l}1,32334 \\
3,44933\end{array}$ \\
\hline Solo exposto & $\begin{array}{l}\text { Min } \\
\text { Max }\end{array}$ & $\begin{array}{l}102,60909 \\
141,19688\end{array}$ & $\begin{array}{l}0,00762 \\
0,10217\end{array}$ & $\begin{array}{c}440,43305 \\
6542,309\end{array}$ & $\begin{array}{l}4,18377 \\
8,08435\end{array}$ & $\begin{array}{l}17,69080 \\
55,52185\end{array}$ & $\begin{array}{l}0,29663 \\
0,78787\end{array}$ & $\begin{array}{l}12,90712 \\
68,81818\end{array}$ & $\begin{array}{l}0,00039 \\
0,01719\end{array}$ & $\begin{array}{l}-0,75921 \\
-0,59670\end{array}$ & $\begin{array}{l}0,15599 \\
0,33642\end{array}$ & $\begin{array}{l}1,41863 \\
1,73223\end{array}$ & $\begin{array}{l}947,73571 \\
1471,3714\end{array}$ & $\begin{array}{l}1080,5250 \\
1643,7400\end{array}$ & $\begin{array}{l}1,92025 \\
2,75593\end{array}$ \\
\hline Sombra & $\begin{array}{l}\text { Min } \\
\text { Max }\end{array}$ & $\begin{array}{l}113,02358 \\
138,32893\end{array}$ & $\begin{array}{l}0,00873 \\
0,10326\end{array}$ & $\begin{array}{l}432,67190 \\
5678,6405\end{array}$ & $\begin{array}{l}5,05269 \\
8,15197\end{array}$ & $\begin{array}{l}25,31680 \\
55,54608\end{array}$ & $\begin{array}{l}0,28239 \\
0,81392\end{array}$ & $\begin{array}{l}13,38301 \\
57,57957\end{array}$ & $\begin{array}{l}0,00035 \\
0,00678\end{array}$ & $\begin{array}{l}-0,54991 \\
-0,28096\end{array}$ & $\begin{array}{l}-0,21706 \\
0,24978\end{array}$ & $\begin{array}{l}0,71999 \\
1,30282\end{array}$ & $\begin{array}{l}866,04699 \\
3137,3975\end{array}$ & $\begin{array}{l}958,76974 \\
3483,5121\end{array}$ & $\begin{array}{l}1,24393 \\
1,72339\end{array}$ \\
\hline $\begin{array}{l}\text { Degradação florestal } \\
\text { recente }\end{array}$ & $\begin{array}{l}\text { Min } \\
\text { Max }\end{array}$ & $\begin{array}{l}114,25984 \\
143,89063\end{array}$ & $\begin{array}{l}0,00438 \\
0,08308\end{array}$ & $\begin{array}{l}440,96429 \\
4559,6535\end{array}$ & $\begin{array}{l}4,26776 \\
8,58018\end{array}$ & $\begin{array}{l}16,92465 \\
54,84175\end{array}$ & $\begin{array}{l}0,16128 \\
0,79323\end{array}$ & $\begin{array}{l}16,30556 \\
59,08661\end{array}$ & $\begin{array}{l}0,00024 \\
0,01645\end{array}$ & $\begin{array}{l}-0,76484 \\
-0,48329\end{array}$ & $\begin{array}{l}-0,02307 \\
0,36140\end{array}$ & $\begin{array}{l}1,16341 \\
1,76436\end{array}$ & $\begin{array}{l}786,02500 \\
1444,6391\end{array}$ & $\begin{array}{l}880,94219 \\
1566,9211\end{array}$ & $\begin{array}{l}1,28814 \\
2,87803\end{array}$ \\
\hline Floresta. Sec. até $5 \mathrm{~m}$ & $\begin{array}{l}\text { Min } \\
\text { Max }\end{array}$ & $\begin{array}{l}127,32000 \\
142,00673\end{array}$ & $\begin{array}{l}0,01457 \\
0,21729\end{array}$ & $\begin{array}{l}652,87000 \\
3848,4260\end{array}$ & $\begin{array}{l}5,50734 \\
7,69571\end{array}$ & $\begin{array}{l}23,39484 \\
48,97126\end{array}$ & $\begin{array}{l}0,42826 \\
0,84360\end{array}$ & $\begin{array}{l}15,01358 \\
48,53363\end{array}$ & $\begin{array}{l}0,00060 \\
0,00527\end{array}$ & $\begin{array}{l}-0,75403 \\
0,02120\end{array}$ & $\begin{array}{l}0,00357 \\
0,51212\end{array}$ & $\begin{array}{l}0,69460 \\
1,76603\end{array}$ & $\begin{array}{l}229,59371 \\
816,84468\end{array}$ & $\begin{array}{l}244,26783 \\
907,36628\end{array}$ & $\begin{array}{l}0,77246 \\
3,03631\end{array}$ \\
\hline $\begin{array}{l}\text { Floresta Sec. } 5 \mathrm{~m} \text { a } \\
15 \mathrm{~m}\end{array}$ & $\begin{array}{l}\text { Min } \\
\text { Max }\end{array}$ & $\begin{array}{l}117,52422 \\
131,32280\end{array}$ & $\begin{array}{l}0,00752 \\
0,11301\end{array}$ & $\begin{array}{l}368,24446 \\
2570,7863\end{array}$ & $\begin{array}{l}5,32995 \\
8,78642\end{array}$ & $\begin{array}{l}17,49880 \\
42,99372\end{array}$ & $\begin{array}{l}0,34895 \\
0,79241\end{array}$ & $\begin{array}{l}10,91513 \\
38,47293\end{array}$ & $\begin{array}{l}0,00021 \\
0,00513\end{array}$ & $\begin{array}{l}-0,82269 \\
-0,69489\end{array}$ & $\begin{array}{l}0,23433 \\
0,43451\end{array}$ & $\begin{array}{l}1,58380 \\
1,83933\end{array}$ & $\begin{array}{l}913,56424 \\
1289,6040\end{array}$ & $\begin{array}{l}1042,1315 \\
1465,7852\end{array}$ & $\begin{array}{l}2,31615 \\
3,24950\end{array}$ \\
\hline Floresta madura & $\begin{array}{l}\text { Min } \\
\text { Max }\end{array}$ & $\begin{array}{l}108,44159 \\
148,76214\end{array}$ & $\begin{array}{l}0,00659 \\
0,07653\end{array}$ & $\begin{array}{l}208,69053 \\
5147,9708\end{array}$ & $\begin{array}{l}4,84405 \\
9,05885\end{array}$ & $\begin{array}{l}13,38395 \\
51,11293\end{array}$ & $\begin{array}{l}0,02154 \\
0,74729\end{array}$ & $\begin{array}{l}11,06928 \\
61,11650\end{array}$ & $\begin{array}{l}0,00016 \\
0,00891\end{array}$ & $\begin{array}{l}-0,81160 \\
-0,48688\end{array}$ & $\begin{array}{l}0,14691 \\
0,43158\end{array}$ & $\begin{array}{l}1,20575 \\
1,81957\end{array}$ & $\begin{array}{l}545,63095 \\
1112,3143\end{array}$ & $\begin{array}{l}617,56944 \\
1264,2000\end{array}$ & $\begin{array}{l}1,54912 \\
3,20355\end{array}$ \\
\hline
\end{tabular}

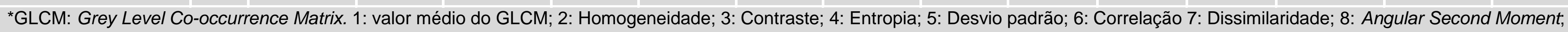

9: NDWI 10: NDMI; 11: SAVI; 12: Média das bandas; 13: Brilho; 14. Máxima Diferença 


\subsubsection{Construção das árvores de decisão}

Árvores e regras de decisão são abordagens de mineração de dados aplicadas nas mais variadas situações do mundo real e representam uma poderosa alternativa às abordagens tradicionais de classificação do uso e cobertura da terra (HANSEN, DUBAYAH; DEFRIES, 1996; KANTARDZIC, 2011. Uma representação estrutural de uma árvore de decisão é apresentada na Figura 21, na qual se observa que sua estrutura é por um nó raiz, outros nós filhos, ramos e folhas.

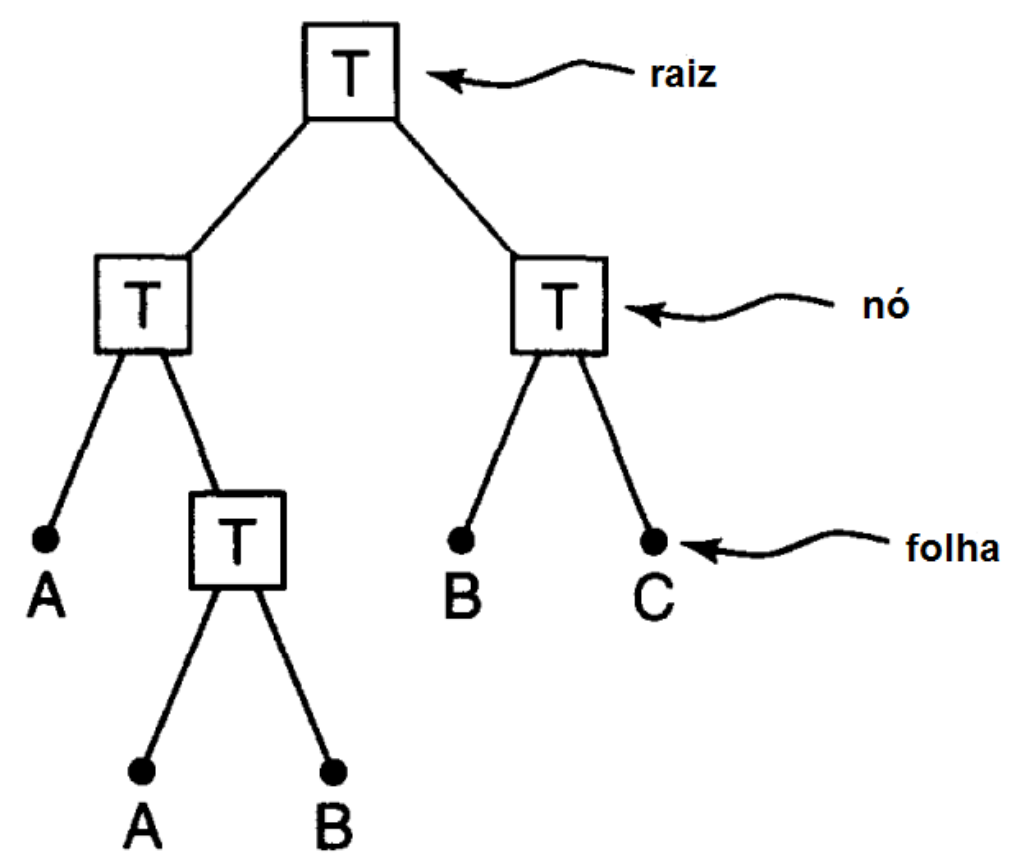

Figura 21 - Representação de uma árvore de decisão

Fonte: Adaptado de Frield e Brodley (1997).

$\mathrm{Na}$ árvore de decisão, os nós representam regiões onde são realizados testes para separação dos dados, enquanto as folhas são as regiões que estão associadas a rótulo ou um valor (SATO et al., 2013; FRIELD e BRODLEY, 1997). Nela os dados de entrada constituem-se por uma coleção de atributos, enquanto o dado de saída é uma árvore com dois nós correspondentes a maior diferença entre atributos (BREIMAN et al., 1984). A capacidade de processar grandes volumes de dados em poucos segundos são alguns dos aspectos mais relevantes do uso de árvores e de decisão (HANSEN, DUBAYAH; DEFRIES, 1996)

. Neste estudo os resultados da primeira classificação foram utilizados como dados de entrada no WEKA (FRANK; HALL; WITTEN, 2016), um aplicativo de código aberto que gera classificações e as apresenta como estruturas de decisão 
encadeadas, como é possível verificar no APÊNDICE 1, que apresenta as árvores de decisão criadas para as classificações de 1986, 1996, 2006, 2012, 2015 e 2016.

O WEKA dispõe de classificadores variados, mas apesentados majoritariamente em arquivos de texto em formato de estrutura de decisão, com recursos limitados para a construção de árvores de decisão. Em contraste, uma alternativa para a criação de árvores são os classificadores do RAPIDMINER STUDIO (MIERSWA et al., 2006; RAPIDMINER, 2017), tendo alguns classificadores em comum como o SIMPLECART (BREIMAN et al., 1984) e o RANDOMTREE.

Uma árvore de decisão para a classificação de 2015 é apresentada na Figura 22. No entanto esta classificação gerada no RAPIDMINER STUDIO é ilustrativa e os valores de saída não foram usados na classificação do uso e cobertura conduzida no ECOGNITION (TRIMBLE, 2016). A árvore utilizada para a classificação de uso e cobertura em 2015 foi gerada no WEKA e está apresentada no APÊNDICE 1.

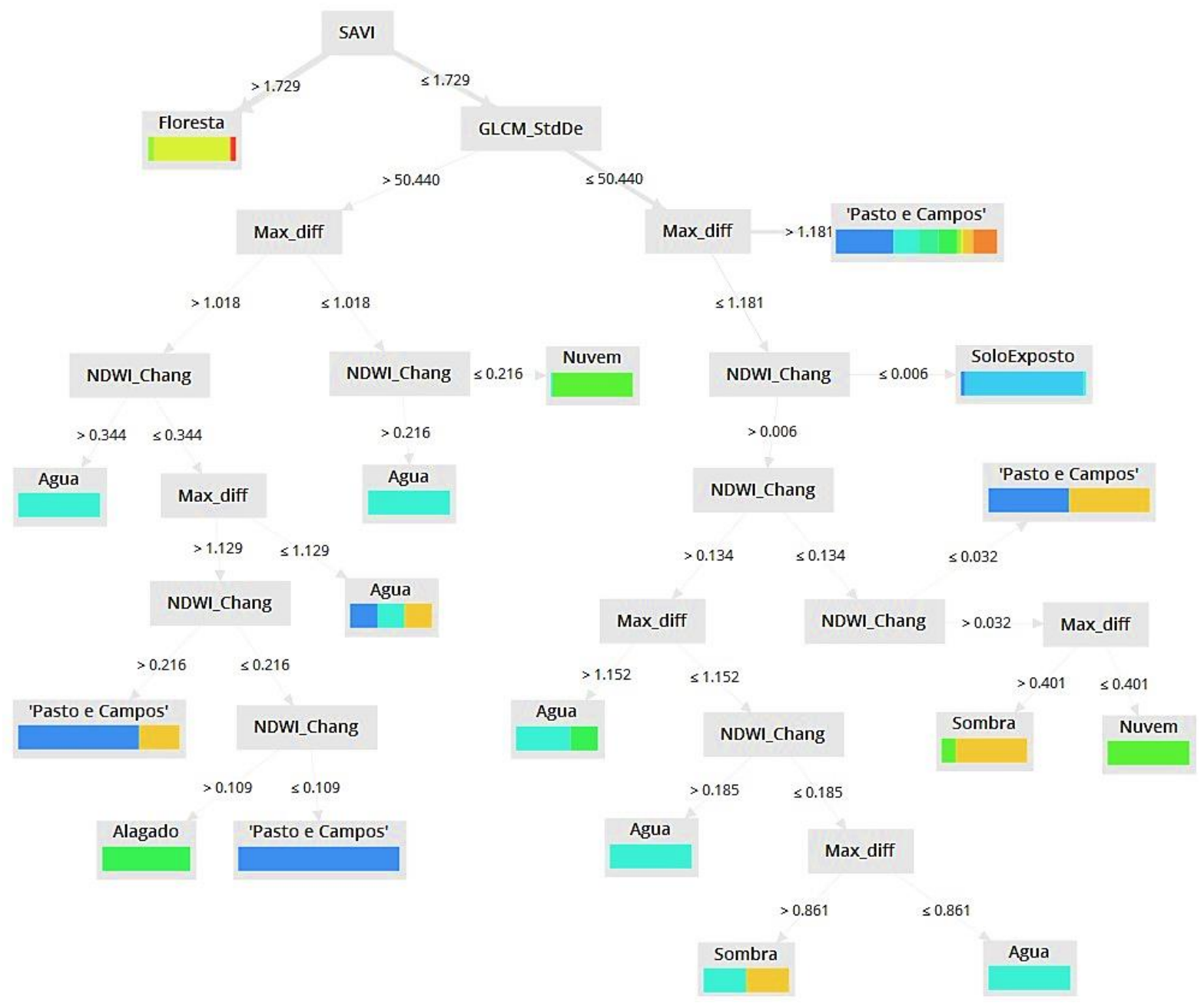

Figura 22 - Árvore de decisão gráfica para a classificação de 2015 
Como é possível observar na Figura 22, a árvore de decisão possui um nó raiz com um atributo SAVI e outros nós filhos com atributos distintos como o índice de vegetação NDWI, textura GLCM, brilho e média das bandas. Relacionado aos nós filhos estão as folhas com os valores e categorias de classificação do uso e cobertura da terra. Tal como indica a Tabela 14, foram usadas 2.099 instâncias como dado de entrada; enquanto ao utilizar o SIMPLECART (BREIMAN et al., 1984) no WEKA foram contempladas todas as classes, com a árvore de decisão criada no RAPIDMINER STUDIO (MIERSWA et al., 2006; RAPIDMINER, 2017) as classes de floresta secundária e floresta madura não foram contempladas na classificação.

\subsubsection{Classificação das imagens}

O processo de atribuir significado a um pixel em função de suas propriedades numéricas é chamado genericamente de "classificação". As técnicas de classificação visam, em última análise, atribuir a cada pixel um rótulo em função de suas propriedades espectrais e espaciais (NOVO, 2008).

As técnicas de classificação se resumem, basicamente, a algoritmos de classificação não supervisionada e algoritmos de classificação supervisionada. Enquanto o primeiro é baseado no reconhecimento não supervisionado de padrões, conforme a homogeneidade e distribuição de níveis de cinza na imagem, o segundo conta com a intervenção do usuário na coleta de amostras de treinamento que o algoritmo utilizará como referência para reconhecimento de padrões de semelhança na imagem.

Neste estudo foram utilizadas duas diferentes técnicas de classificação supervisionada: do vizinho mais próximo (Nearest Neighborhood) e a associação de classes (Assign Class), ambas disponíveis no aplicativo ECOGNITION (TRIMBLE, 2016). A primeira técnica foi aplicada após a coleta das amostras de treinamento, enquanto a segunda técnica foi aplicada após a construção das árvores de decisão com os dados de classificação criados no WEKA.

A segunda classificação foi construída, portanto sem a coleta direta de amostras de treinamento, mas tendo como referência o intervalo entre os valores limiares (Tabela 15) de cada atributo para construção de uma árvore de decisão que pudesse ser aplicada em imagens coletadas em diferentes períodos. 


\subsubsection{Análise dos resultados em SIG}

Para análise e validação dos resultados das duas classificações foi utilizado um SIG graças à possibilidade de aquisição, conversão, análise, visualização e armazenamento em estrutura de banco de dados por ele oferecida. O SIG pode ser definido como a combinação entre as partes física e lógica de um computador (hardware e software, respectivamente), dados geométricos e alfanuméricos, metodologias e recursos humanos, que operam de modo harmônico na produção e análise de informações geográficas (MENEZES, 2006).

Alguns aplicativos de processamento de imagem como o ENVI (EXILIS, 2014) oferecem funções de análise estatística de imagens e classificações, mas não o ECOGNITION (TRMBLE, 2016), que nesta área limita-se a permitir a conversão da classificação resultante para a estrutura de dados matricial (raster) ou vetorial ou, ainda, a importar dados externos como camadas da classificação de maneira a influenciar os parâmetros de associação do algoritmo de classificação. Portanto, para a análise dos resultados não se limitar apenas à avaliação da árvore de decisão foram utilizadas operações de análise do sistema ARCGIS (ESRI, 2015) como a criação de máscaras, a intersecção (ou a fusão) entre diferentes conjuntos de dados, e o cálculo de ocorrência e frequência de um determinado valor (como a área) conforme um atributo qualificador.

Ao analisar a sucessão secundária para três diferentes localidades na Amazônia, Carreiras et al. (2014) realizaram o refinamento da classe floresta madura (SS3) com a adoção de uma máscara gerada a partir da mais recente imagem classificada sem nuvens para cada área analisada. Para tal procedimento os autores utilizam a Interactive Data Language (IDL), assim como para análise comparativa entre as classificações dos diferentes períodos analisados.

Procurou-se replicar o mesmo procedimento neste estudo, entretanto utilizando geoprocessamento e arquivos no formato shapefile e não uma máscara matricial gerada em aplicativo de processamento de imagem. $O$ uso destas máscaras foi necessário pois, como será visto no Capítulo 6 , não foi devidamente mensurado 0 risco de divergências entre a cobertura florestal total entre cada período analisado. Apenas com o uso da máscara foi possível calcular a redução florestal efetiva entre um ano e o outro. 


\section{RESULTADOS E DISCUSSÃO}

O que leva alguns momentos para a faca machete, o trator de esteira ou a motosserra destruir, poderá levar décadas ou séculos para ser reconstruído através do processo da sucessão secundária.

(CHAZDON, 2014, p.74).

\subsection{PRIMEIRAS IMPRESSÕES}

Neste capítulo são apresentados os resultados da validação fotográfica das amostras de treinamento, da análise estatística da primeira classificação realizada com as amostras de treinamento somente, e a classificação final para os períodos analisados e a apresentação, em mapas, dos resultados.

No decorrer do trabalho expectativas foram confirmadas, enquanto outras não. Como exemplo os índices de vegetação mostraram resultados mais que os esperados e acabaram por predominar os critérios da árvore de decisão construída, em contraste com os atributos de textura que apresentaram baixa correlação.

Os resultados da classificação também surpreenderam. A estimativa de cobertura florestal em 1984 é bem maior que o imaginado, e a distribuição das classes SS1 e SS2 de sucessão secundária tiveram extensões variadas para cada período analisado, sem padrão claro de redução ou incremento.

\subsection{RECONHECIMENTOS DE ELEMENTOS EM IMAGENS DE SATÉLITE E LEVANTAMENTO FOTOGRÁFICO}

A construção da chave de classificação teve como referência as classes do levantamento de uso da terra para a Amazônia TERRACLASS (INPE-CRA, 2014) e os estágios de sucessão secundária identificados para a Amazônia por Chazdon (2012). Assim, ao invés de trabalhar com uma única classe de floresta secundária, procurou-se aqui trabalhar com pelo menos duas classes de sucessão que permitissem responder qual o padrão na destruição das florestas secundárias. 
Para chegar a tal objetivo foi necessário reconhecer também as demais classes de uso e cobertura da terra, das quais se apresentam os elementos de reconhecimento visual apresentados na Figura $23 .$.

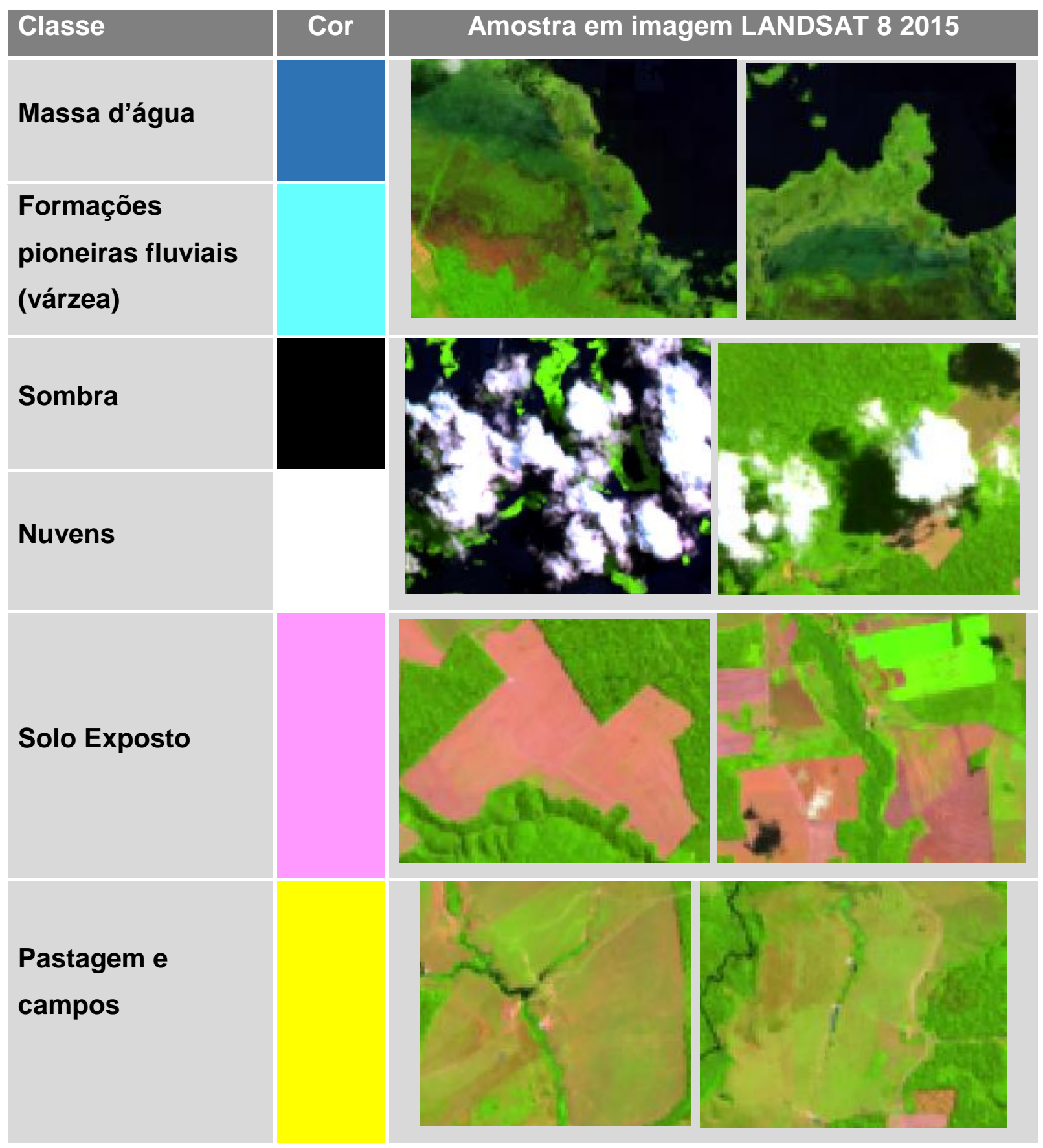




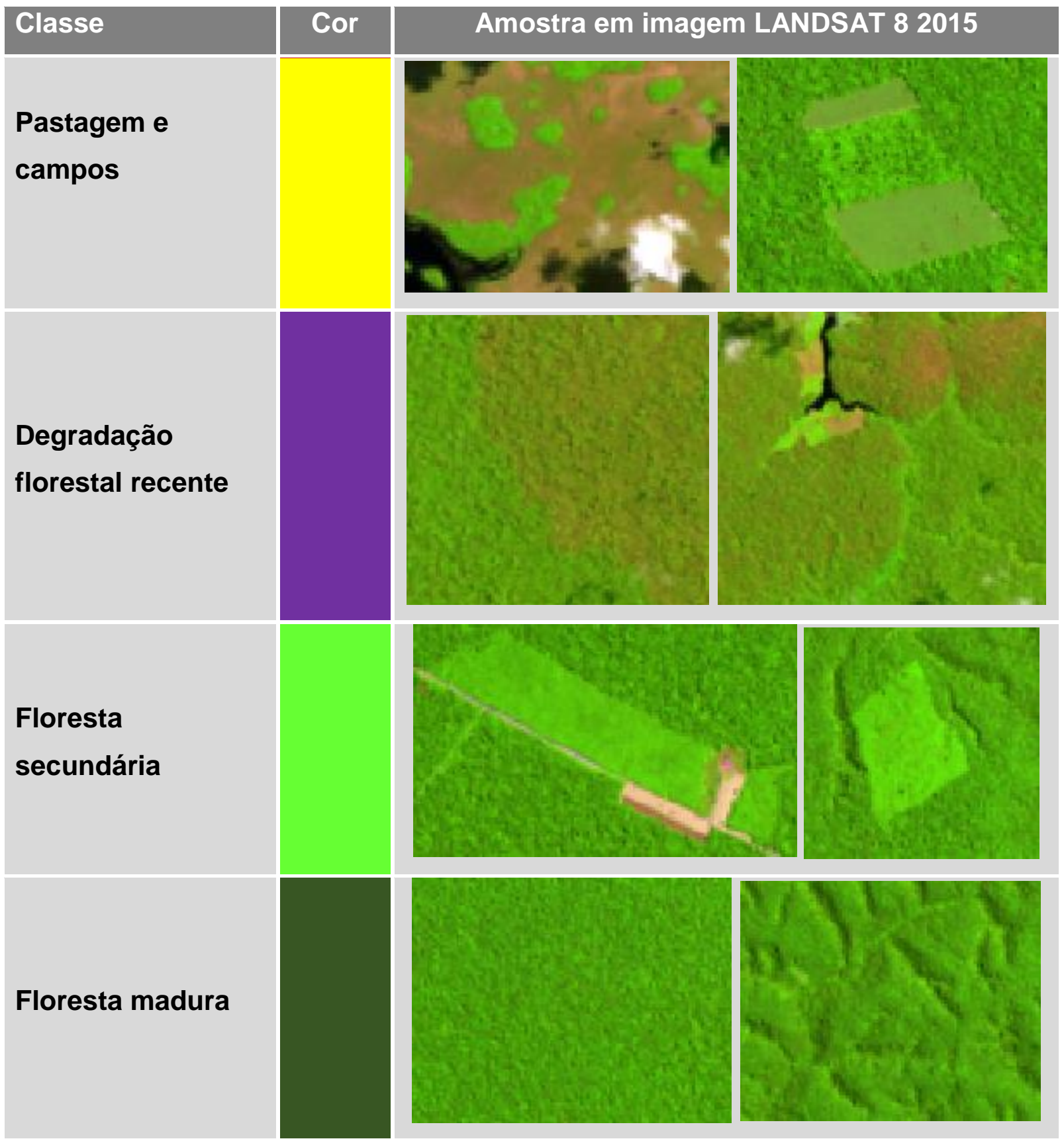

Figura 23 - Elementos reconhecíveis na classificação de imagem

Fonte: composição colorida (bandas r6, g5, b4) de cena (órbita 22 e ponto 062) do sensor LANDSAT- 8 datada de 14 de agosto de 2015. 
Os critérios de reconhecimento visual das imagens para a coleta de amostras de treinamento seguiu o reconhecimento das propriedades que caracterizam a cor, o brilho, a tonalidade e a textura da imagem conforme referência em Novo (2008). A compreensão destas propriedades para o reconhecimento visual dos estágios de sucessão florestal; enquanto a classe SS1 possui maior brilho e homogeneidade (em resposta a maior liberação de radiação na faixa da luz verde), a classe 3 possui maior heterogeneidade (consequência da maior quantidade de espécies) e brilho menor.

Para auxiliar a coleta de amostras de treinamento foram consultados dois levantamentos fotográficos realizados em 2012. Primeiro, as fotografias de um levantamento aéreo (para fins de controle de mapeamento do uso da terra) realizado para a organização não governamental The Nature Conservancy. Deste levantamento foram selecionadas 76 fotografias (com localização georreferenciada) dispersos ao longo das rodovias BR-163 (Cuiabá-Santarém) e PA-370 (Santarém - Curuá-Una).

Outra fonte complementar de informações de apoio foi o uso de imagens adquiridas em 2012 para o Google Street View (GOOGLE, 2017). Estas imagens foram obtidas através de levantamento terrestre em estradas pavimentadas e não pavimentadas. Foram selecionadas 110 fotografias dispersas na área de estudo. $\mathrm{A}$ descrição dos pontos e a visualização das imagens utilizadas como controle podem ser consultadas na página:

https://www.google.com/maps/d/edit?mid=1Jbr4qKD3DEyjiiJOViFnOEOX6to\&ll=2.981745938322087\%2C-54.41423750000001\&z=9

Cada levantamento atendeu diferentes perspectivas. As imagens do levantamento aéreo foram muito úteis para ter visão panorâmica dos estratos vegetais, enquanto as imagens do Google Street View (GOOGLE, 2017) ajudaram a ter uma visão dos pontos de observação no chão, complementando o levantamento aéreo. Todos os pontos são apresentados no Mapa 3.

Na Figura 24 é possível verificar quatro diferentes fragmentos com regeneração florestal em curso com destaque para o primeiro fragmento (canto superior) que mostra três diferentes estágios num único local: o pousio, o pasto sujo e a floresta secundária. Outros ambientes distintos na classificação são a planície de inundação (Figura 28), o cerrado ou savana parque (Figura 30), a floresta madura (Figura 29), e o solo exposto para o plantio de grãos (Figura 31). 


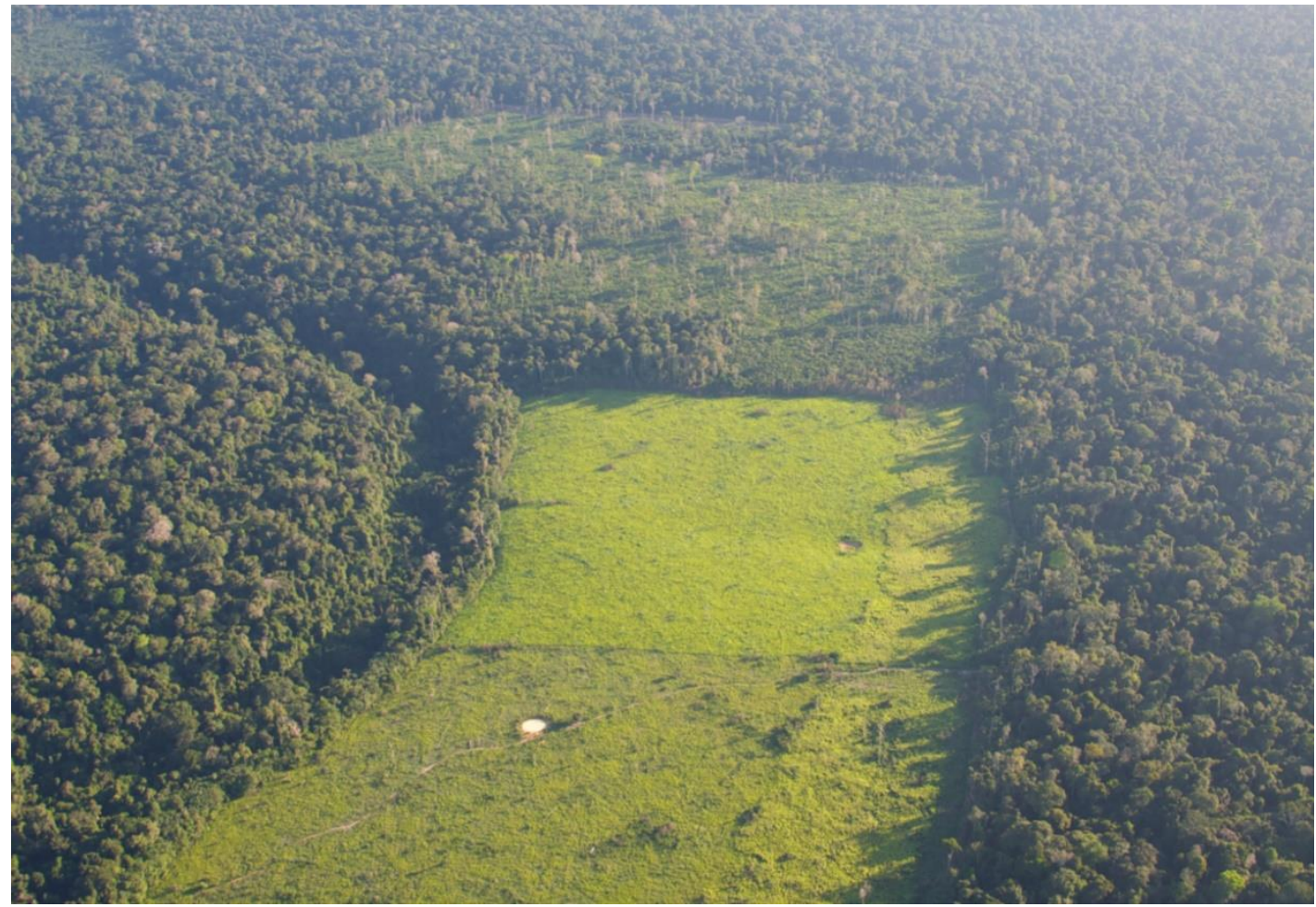

Figura 24 - Transição entre pastagem, SS2 (fundo) e SS3 (lateral) Localização: $\Phi: 3^{\circ} 5^{\prime} 14,122 "$ S - $\lambda$ : 54 40' 52,046" W

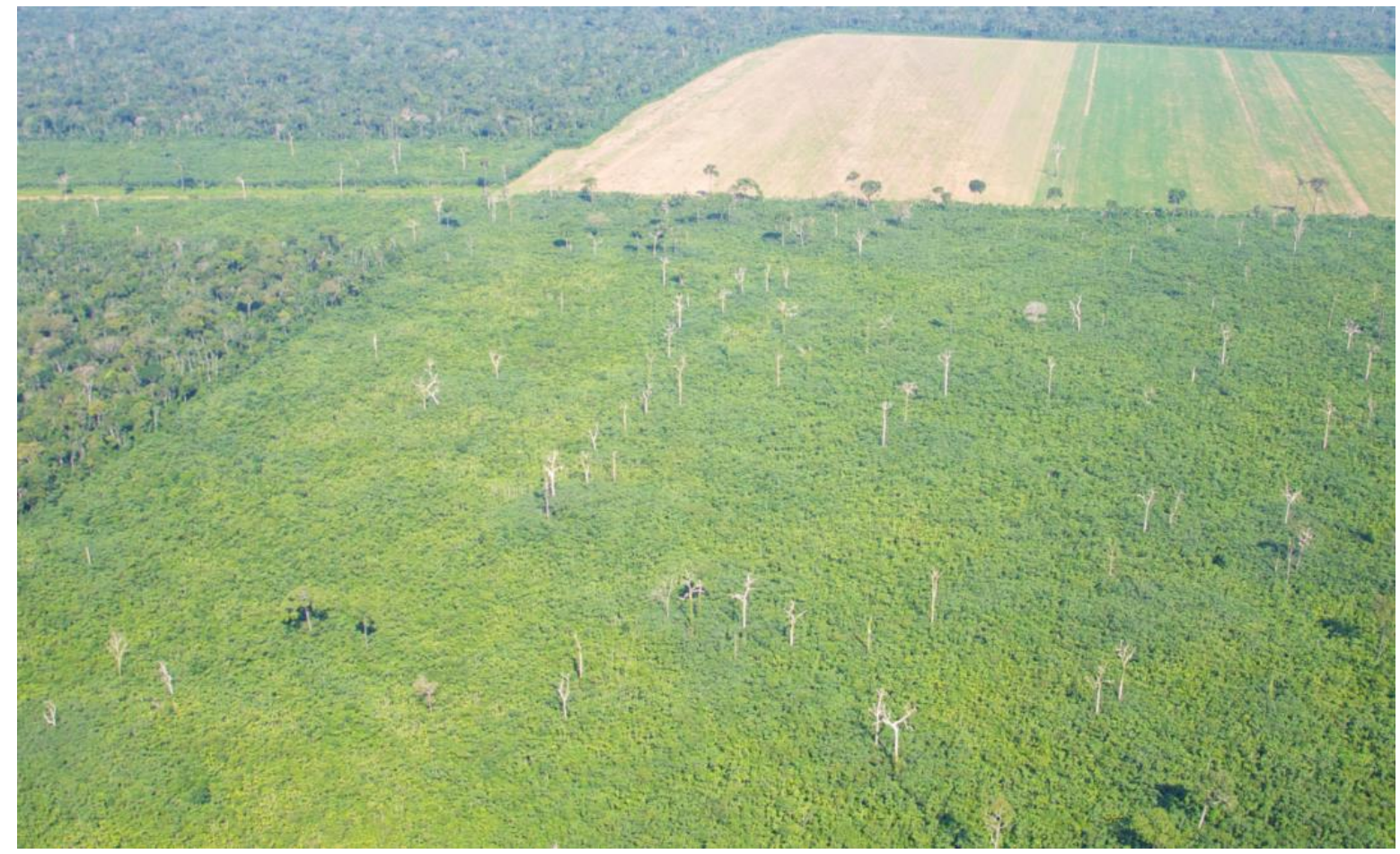

Figura 25 - Área desmatada em 2005 e em regeneração (SS1) Localização: $\Phi: 2^{\circ} 55^{\prime} 24,747^{\prime \prime}$ S - $\lambda$ : 53 57' 52,617" W 


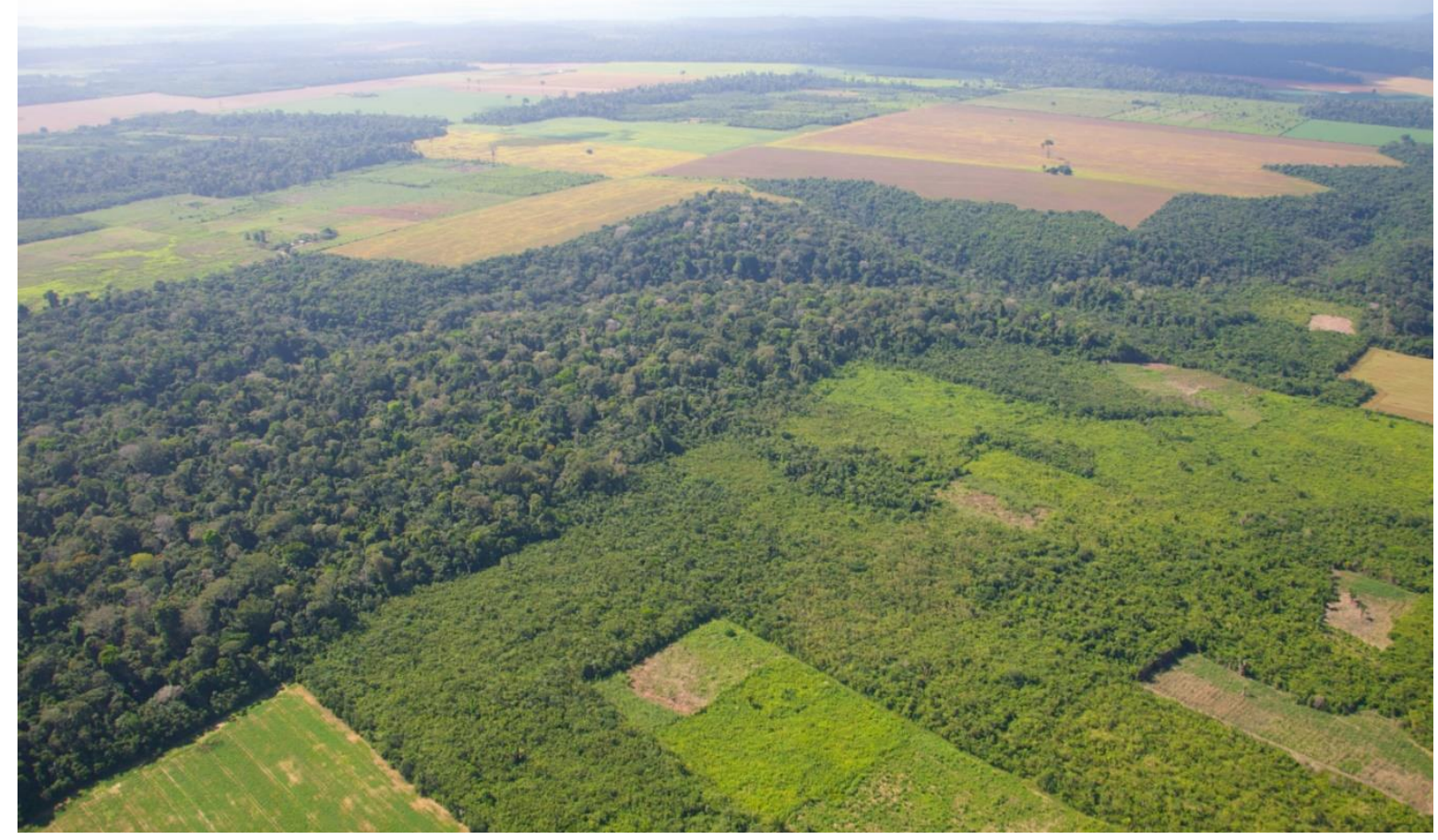

Figura 26 - Transição entre regeneração (SS1) e floresta madura (SS3)

Localização: $\Phi: 2^{\circ} 42^{\prime} 3,138^{\prime \prime}$ S - $\lambda: 54^{\circ} 29^{\prime} 41,343^{\prime \prime}$ W

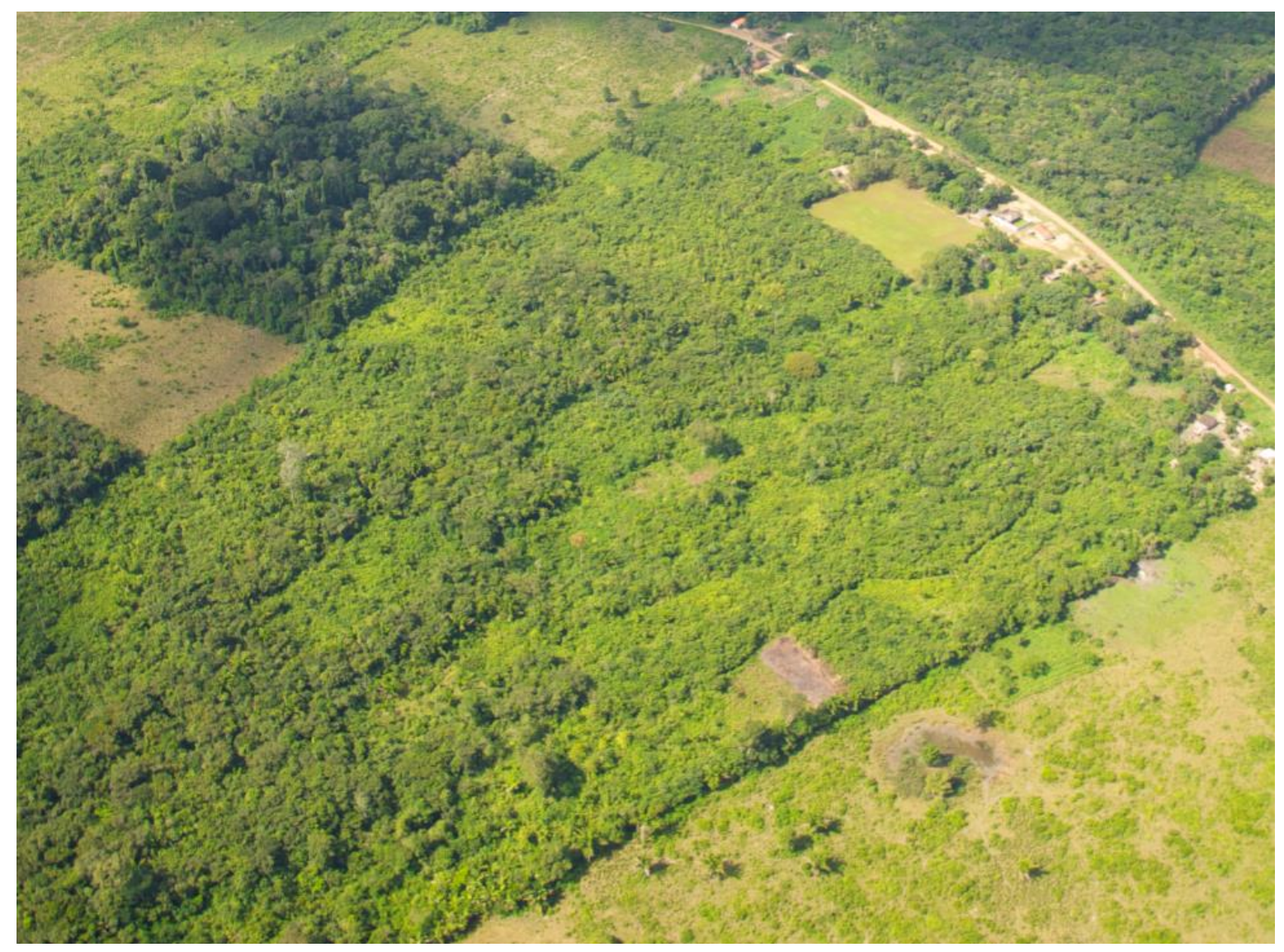

Figura 27 - Transição entre dois estágios de regeneração (SS1 e SS2) Localização: $\Phi: 2^{\circ} 44^{\prime} 20,610^{\prime \prime}$ S - $\lambda: 54^{\circ} 53^{\prime} 35,199^{\prime \prime}$ W 


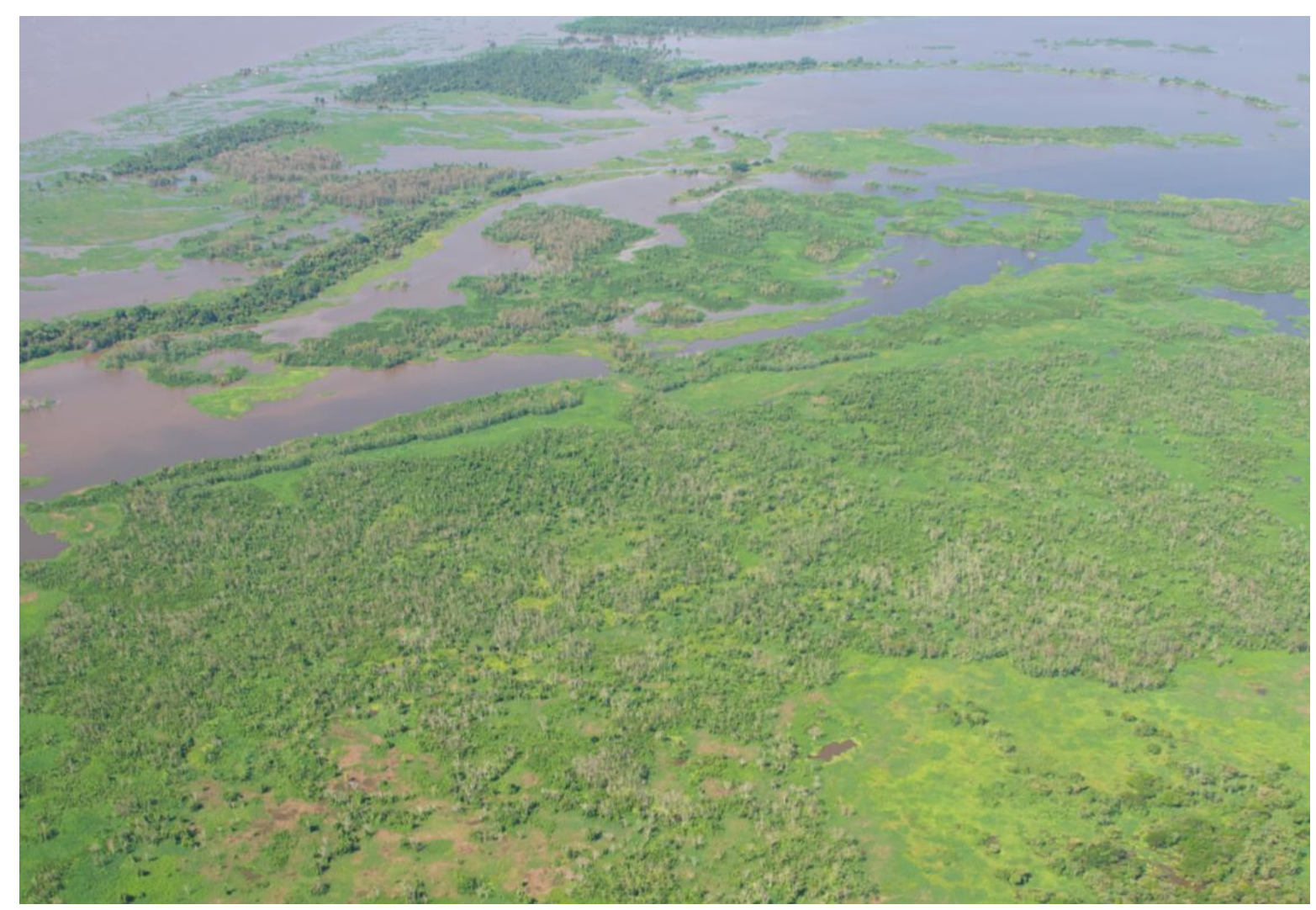

Figura 28 - Floresta de inundação e macrófitas (aninga - Montichardia Araceae) na várzea do rio Amazonas

Localização: $\Phi: 2^{\circ} 29^{\prime} 9,568^{\prime \prime}$ S - $\lambda$ : 54² 32' 33,614" W

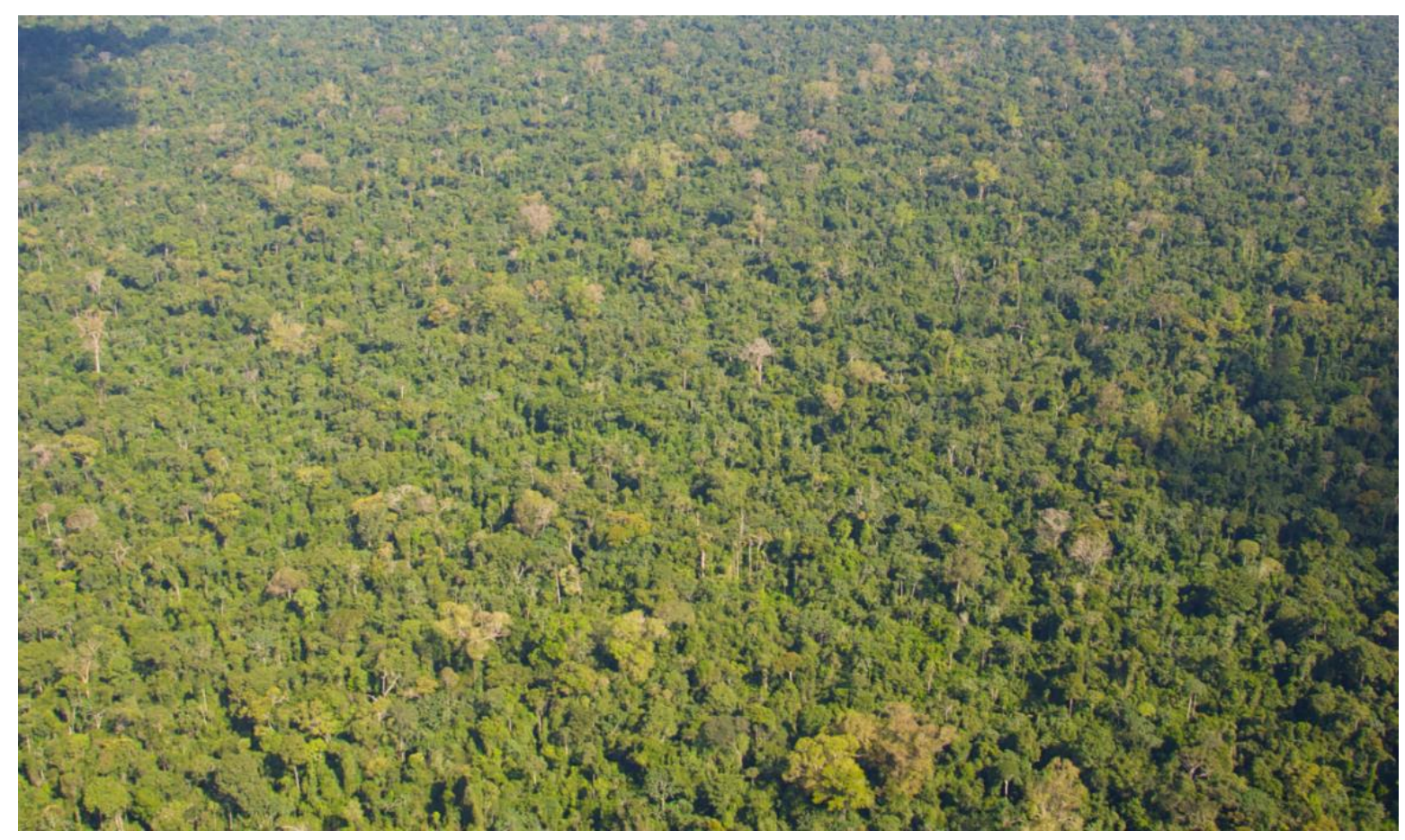

Figura 29 - Floresta madura (SS3)

Localização: $\Phi: 2^{\circ} 58^{\prime} 20,385^{\prime \prime}$ S - $\lambda: 54^{\circ} 3^{\prime} 27,273^{\prime \prime}$ W 


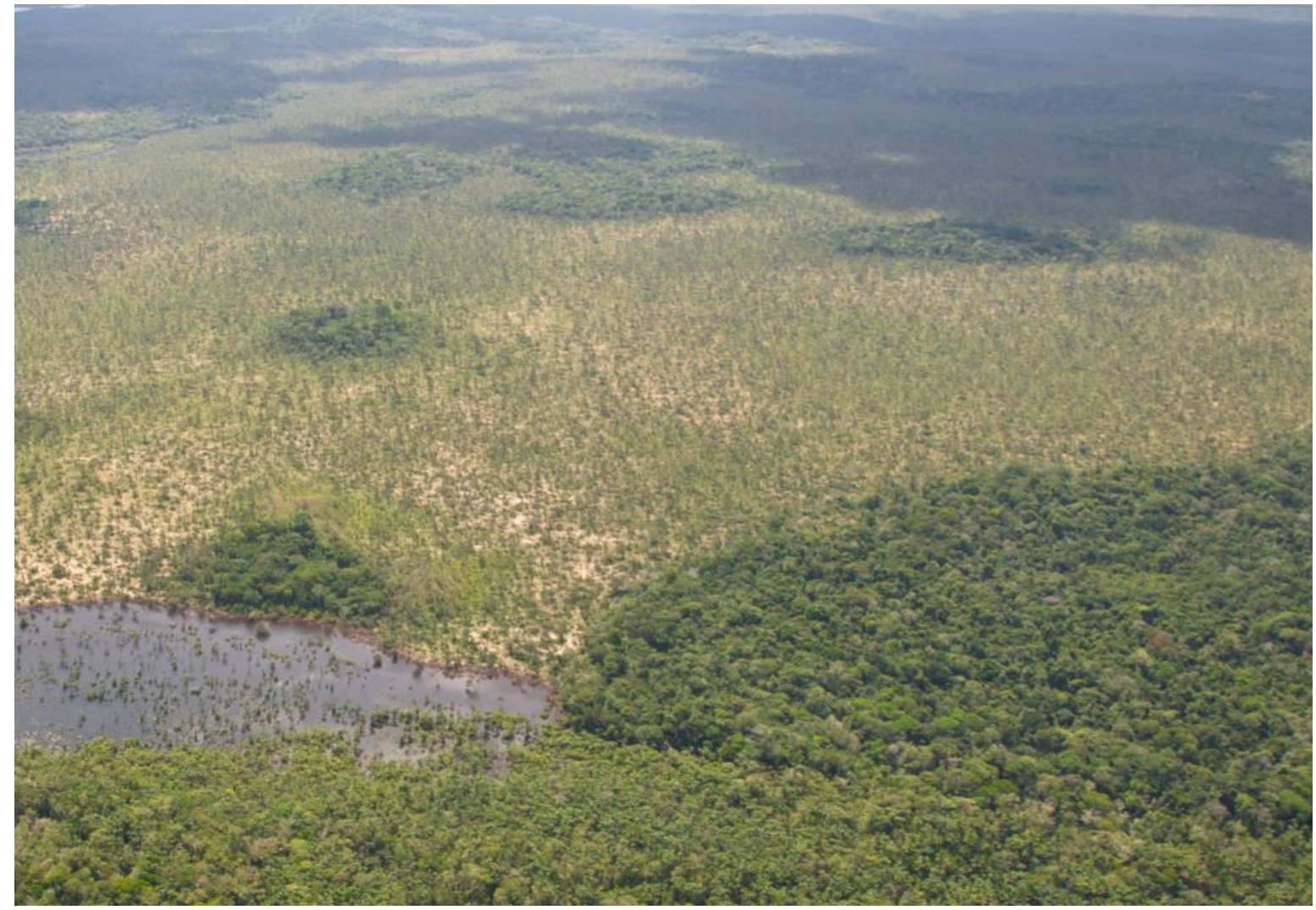

Figura 30 - Savana parque (cerrado) próximo a Alter do Chão Localização: Ф: $2^{\circ} 31^{\prime} 33,975 "$ S - $\lambda$ : $54^{\circ} 55^{\prime}$ 40,870" W

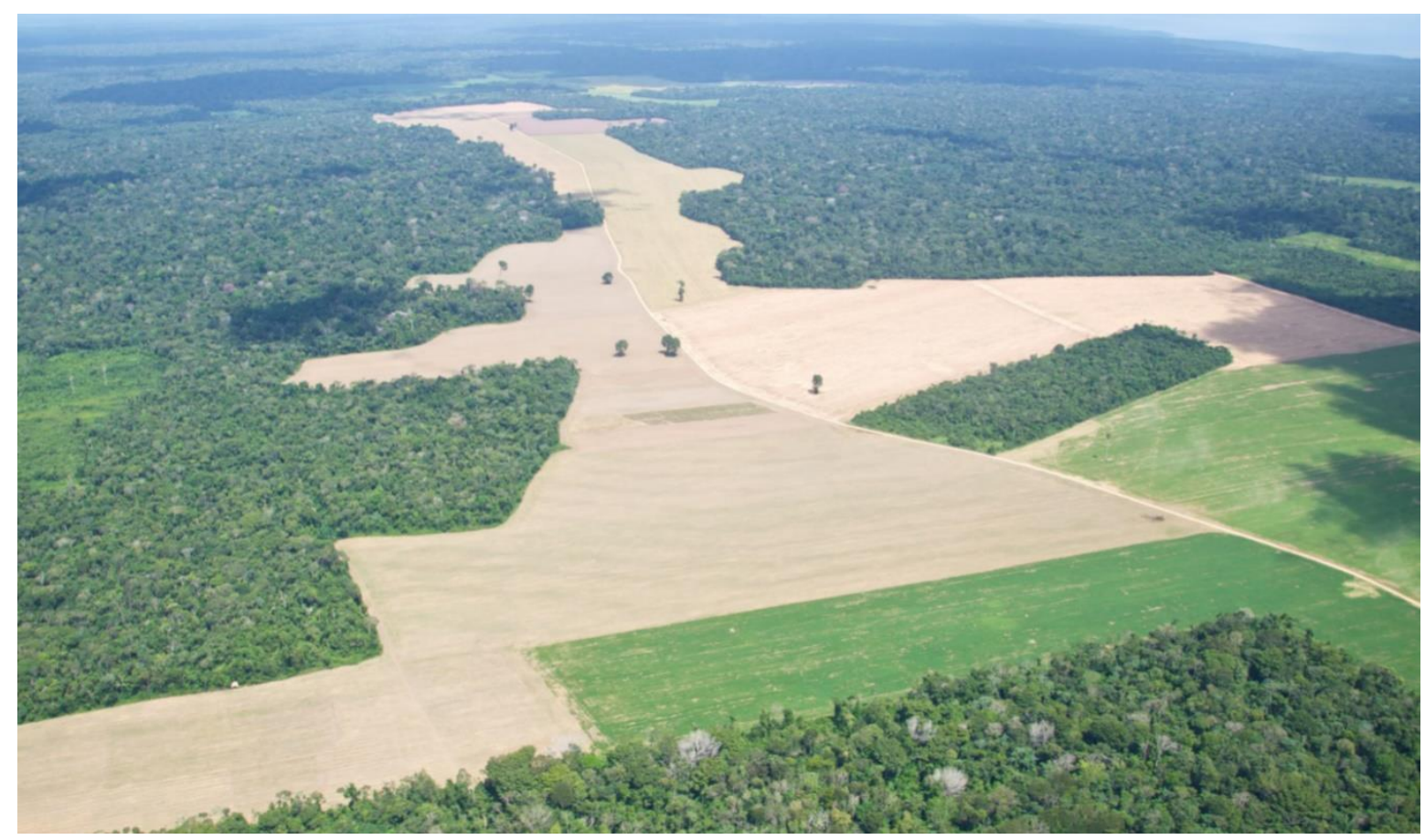

Figura 31 - Área destinada a agricultura anual em Belterra

Localização: Ф: $2^{\circ} 41^{\prime} 11,115^{\prime \prime}$ S - $\lambda$ : 54 54' 52,344" W 


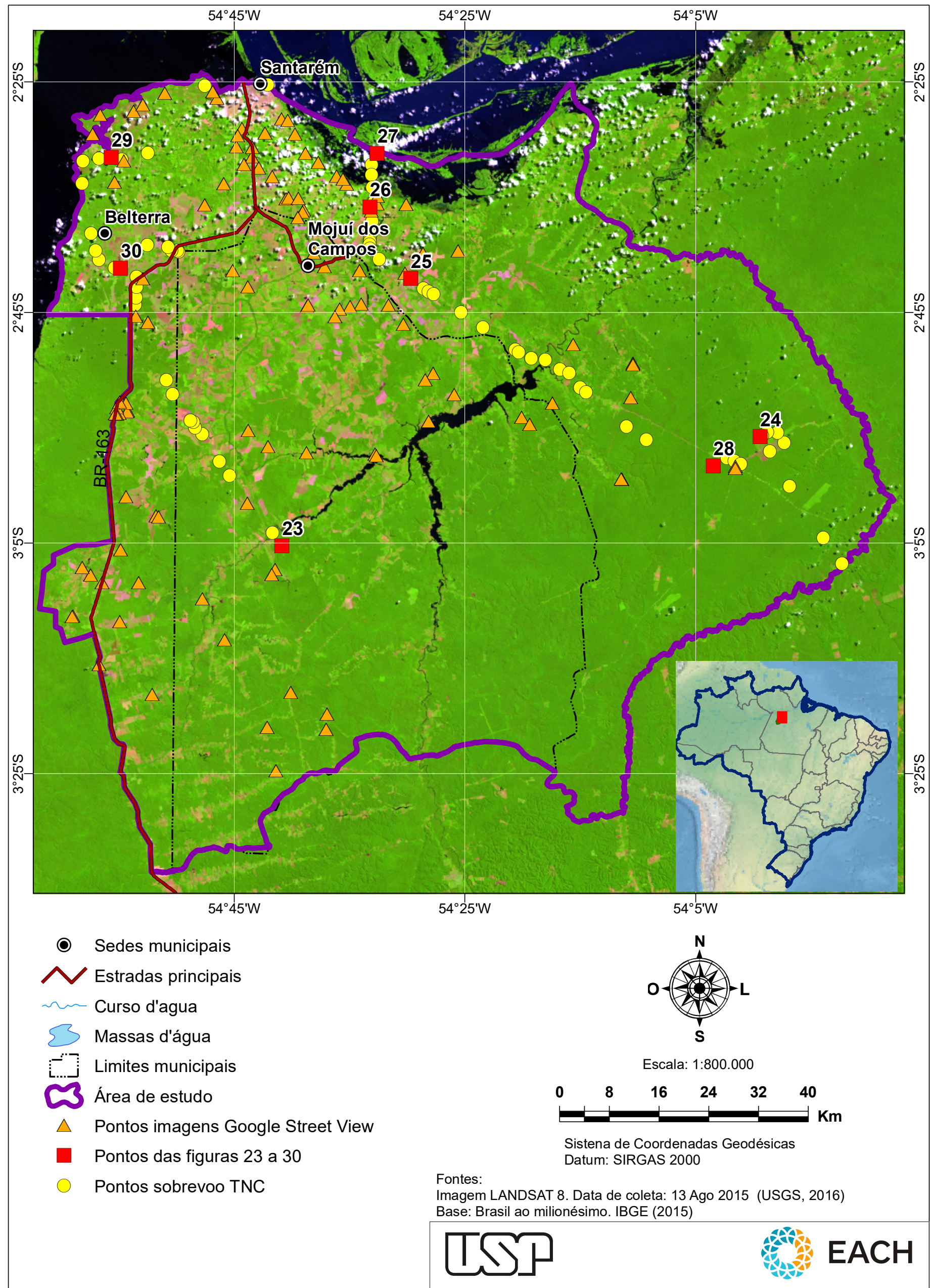

Regeneração florestal após o desmatamento: estudo da região de Santarém Diego Pinheiro de Menezes

Mapa 3 Localização dos pontos de verificação 


\subsection{AVALIAÇÃO DA PERFORMANCE DA CLASSIFICAÇÃO}

Os resultados da árvore de decisão gerada no WEKA (FRANK; HALL; WITTEN, 2016) aplicada a todos os períodos de classificação, demonstraram a preponderância dos valores dos índices de vegetação como limiares de separação das classes na árvore de decisão quando comparados aos demais atributos, especialmente as propriedades de textura GLCM.

Conforme pode ser verificado no APÊNDICE 2, a análise estatística de 2.099 amostras de treinamento (para a classificação de 2015) revela que foi criada uma árvore de decisão com 37 nós e 73 folhas subordinadas. O acerto médio ficou em $89,85 \%$ e, o erro médio, corresponde à $10,14 \%$ das instâncias classificadas. Para chegar a este acerto foram realizados testes com o objetivo de determinar qual o melhor algoritmo para classificação com a menor árvore e o maior Kappa possível, mas contemplando todas as categorias do mapeamento.

O primeiro teste realizado procurou compreender como a quantidade de instâncias utilizadas como dado de entrada do algoritmo influenciariam no tamanho e percentual de acerto da árvore de decisão. Assim, foram realizados seis testes apenas com o classificador SIMPLECART (BREIMAN et al., 1984) utilizando os pouco mais de 48 mil objetos (instâncias) geradas para a primeira classificação de uso e cobertura da terra em 2015. Como resultado, os dados apresentados na Tabela 16 mostram a relação direta entre a quantidade de instâncias na entrada e o número de nós e folhas na árvore de decisão.

Também foi possível notar a relação direta entre a quantidade de instâncias e o tempo de execução, mas não foi verificado uma piora significativa com a redução na quantidade de instâncias. Conforme mostra a Tabela 16 os menores percentuais de acerto foram com a massa completa de dados e com a seleção aleatória de 1.500 instâncias desta massa de dados.

Tabela 16 - Comparação de quantidade de amostras usando o SIMPLECART

\begin{tabular}{|c|c|c|c|c|c|c|}
\hline Instâncias & № Nós & № Folhas & Tempo (s) & Acerto \% & Erro \% & Kappa \\
\hline 1.500 & 27 & 53 & 0,51 & 96 & 4 & 0,928 \\
\hline 2.500 & 51 & 100 & 1,68 & 100 & 0 & 1 \\
\hline 5.000 & 71 & 141 & 3,70 & 100 & 1 & 1 \\
\hline 10.000 & 138 & 275 & 7,35 & 98 & 2 & 0,9638 \\
\hline 11.000 & 134 & 267 & 5,20 & 100 & 0 & 1 \\
\hline 48.325 & 546 & 1.091 & 66,08 & 90 & 10 & 0,8637 \\
\hline
\end{tabular}


O segundo teste procurou identificar, dentre o grande número de classificadores disponíveis no WEKA, qual o mais apropriado para criar uma árvore de decisão que forneça valores limiares para a classificação de uso e cobertura da terra. Foram avaliados sete classificadores e os critérios eliminatórios foram o tamanho da árvore (número de nós e folhas) e o Kappa. Dois testes são apresentados na Tabela 17, um primeiro com 10.000 instâncias e o segundo com 2.099 instâncias.

Como resultado verificou-se que o primeiro teste apresentou resultados mais homogêneos (mais de um classificador com Kappa igual a 1) e disparidade no tamanho das árvores. Quanto maior a árvore maior será o trabalho de montagem da árvore de processo no ambiente do GEOBIA e também a especificidade para a classificação de uma única imagem de satélite.

Os resultados indicaram uma avaliação positiva do SIMPLECART (BREIMAN et al., 1984) e do J48 (QUINLAN, 1993), considerando tanto o tamanho da árvore como o tempo de execução e o Kappa, optando-se pelo SIMPLECART pelo tamanho menor das árvores. Ao analisar 12 classificadores do WEKA para classificação da cobertura vegetal da FLONA Tapajós, Sato et al. (2013) chegaram à resultados semelhantes.

Tabela 17 - Comparação de classificadores no WEKA

\begin{tabular}{|l|c|c|c|c|c|c|c|}
\hline \multicolumn{7}{|c|}{ Teste 1 - 10.000 instâncias e 14 atributos } \\
\hline Classificador & № Nós & № Folhas & Tempo (s) & Acerto \% & Erro \% & Kappa \\
\hline LADTree & 31 & 100 & 7,01 & 90 & 10 & 0,8239 \\
\hline LMT & 51 & 101 & 263,72 & 98 & 2 & 0,9638 \\
\hline RepTree & 169 & 341 & 0,25 & 98 & 2 & 0,9638 \\
\hline J48 & 517 & 1.033 & 0,72 & 100 & 0 & 1 \\
\hline RandomTree & 1.433 & 2.889 & 0,18 & 100 & 0 & 1 \\
\hline BFTree & 490 & 979 & 12,62 & 100 & 0 & 1 \\
\hline SimpleCart & 126 & 251 & 6,22 & 100 & 0 & 1 \\
\hline \multicolumn{2}{|c|}{ Teste 2-2.099 instâncias e 15 atributos } & & \\
\hline Classificador & № Nós & № Folhas & Tempo (s) & Acerto \% & Erro \% & Kappa \\
\hline LADTree & 31 & 100 & 1,26 & 86,37 & 13,63 & 0,8114 \\
\hline LMT & 6 & 11 & 42,5 & 94,47 & 5,53 & 0,9239 \\
\hline RepTree & 38 & 79 & 0,08 & 91,33 & 8,67 & 0,8799 \\
\hline J48 & 96 & 111 & 0,11 & 97,09 & 2,91 & 0,9600 \\
\hline RandomTree & 216 & 435 & 0,03 & 100 & 0 & 1 \\
\hline BFTree & 167 & 84 & 1,24 & 96,28 & 3,72 & 0,9486 \\
\hline SimpleCart & 37 & 73 & 1 & 92,76 & 7,24 & 0,8996 \\
\hline
\end{tabular}

Deste modo, os testes realizados neste estudo permitiram concluir que as árvores de decisão seriam construídas apenas com as instâncias derivadas dos mesmos segmentos da primeira classificação que serviram como coleta de amostras 
das classes contempladas no mapeamento. Como estes segmentos tiveram verificação com as fotografias dos levantamentos fotográficos consultados (para a classificação de 2015) e na comparação de aspectos visuais e espectrais entre as imagens antigas (sem dados de campo) e as imagens recentes (2012 até 2016).

Com o uso apenas de instâncias derivadas das amostras de cada período classificado procurou-se reduzir a possibilidade de erros de comissão $^{12}$ na classificação. Erros de comissão podem tornar o Kappa baixo e expandir desnecessariamente o tamanho da árvore de decisão. A Tabela 14, anteriormente apresentada, mostra o percentual de segmentos amostrados variou de $0,75 \%$ a $3,00 \%$ do total de segmentos gerados para cada período classificado. Na Tabela 18, a seguir, são apresentados os valores da avaliação estatística da árvore de decisão criada para cada um dos 19 períodos classificados.

\section{Tabela 18 - Resumo das árvores de decisão de cada classificação}

\begin{tabular}{|c|c|c|c|c|c|c|c|}
\hline Ano & № Nós & № Folhas & Tempo (s) & Instâncias & Acerto & Erro & Kappa \\
\hline 2016 & 24 & 47 & 0,74 & 1.705 & 1.582 & 123 & 0,9147 \\
\hline 2015 & 37 & 73 & 0,94 & 2.099 & 1.947 & 152 & 0,8996 \\
\hline 2014 & 31 & 61 & 1,11 & 2.323 & 2.090 & 233 & 0,8789 \\
\hline 2013 & 27 & 53 & 0,80 & 1.740 & 1.637 & 103 & 0,928 \\
\hline 2012 & 30 & 59 & 2.92 & 5.652 & 4.986 & 666 & 0,8431 \\
\hline 2010 & 46 & 91 & 1,48 & 2.689 & 2.503 & 186 & 0,9155 \\
\hline 2009 & 27 & 53 & 0,80 & 1.740 & 1.637 & 103 & 0,928 \\
\hline 2008 & 40 & 79 & 1,15 & 2.407 & 2.258 & 149 & 0,924 \\
\hline 2006 & 58 & 115 & 1,64 & 3.331 & 3.110 & 221 & 0,9155 \\
\hline 2005 & 43 & 85 & 1,22 & 2.309 & 2.129 & 180 & 0,9085 \\
\hline 2004 & 47 & 93 & 0,96 & 1.743 & 1.598 & 145 & 0,8999 \\
\hline 2001 & 36 & 71 & 0.96 & 2.479 & 2.391 & 88 & 0,9527 \\
\hline 1999 & 52 & 103 & 1,18 & 2.455 & 2.273 & 182 & 0,9061 \\
\hline 1997 & 44 & 87 & 0,84 & 1.698 & 1.542 & 156 & 0,892 \\
\hline 1995 & 77 & 153 & 1.47 & 3.208 & 3.043 & 165 & 0,9346 \\
\hline 1991 & 129 & 257 & 1,33 & 2.672 & 2.592 & 80 & 0,9633 \\
\hline 1988 & 34 & 57 & 0,24 & 614 & 585 & 29 & 0,947 \\
\hline 1986 & 30 & 59 & 0,87 & 1.756 & 1.633 & 123 & 0,915 \\
\hline 1984 & 45 & 89 & 0,61 & 1.417 & 1.372 & 45 & 0,9594 \\
\hline
\end{tabular}

É possível verificar na Tabela 18 que algumas classificações se destacaram em relação ao tamanho da árvore (1991), ao tempo de execução e Kappa menor que os demais (2012), e que 14 classificações tiveram Kappa superior a 0,9. A correspondência entre tamanho da árvore e acertos fica bem clara na Figura 32.

${ }^{12}$ Erro de comissão ou inclusão de classe: objeto incorretamente classificado. 
A relação direta entre Kappa e erro médio pode ser verificada na Figura 33, com destaque para a classificação de 2012.

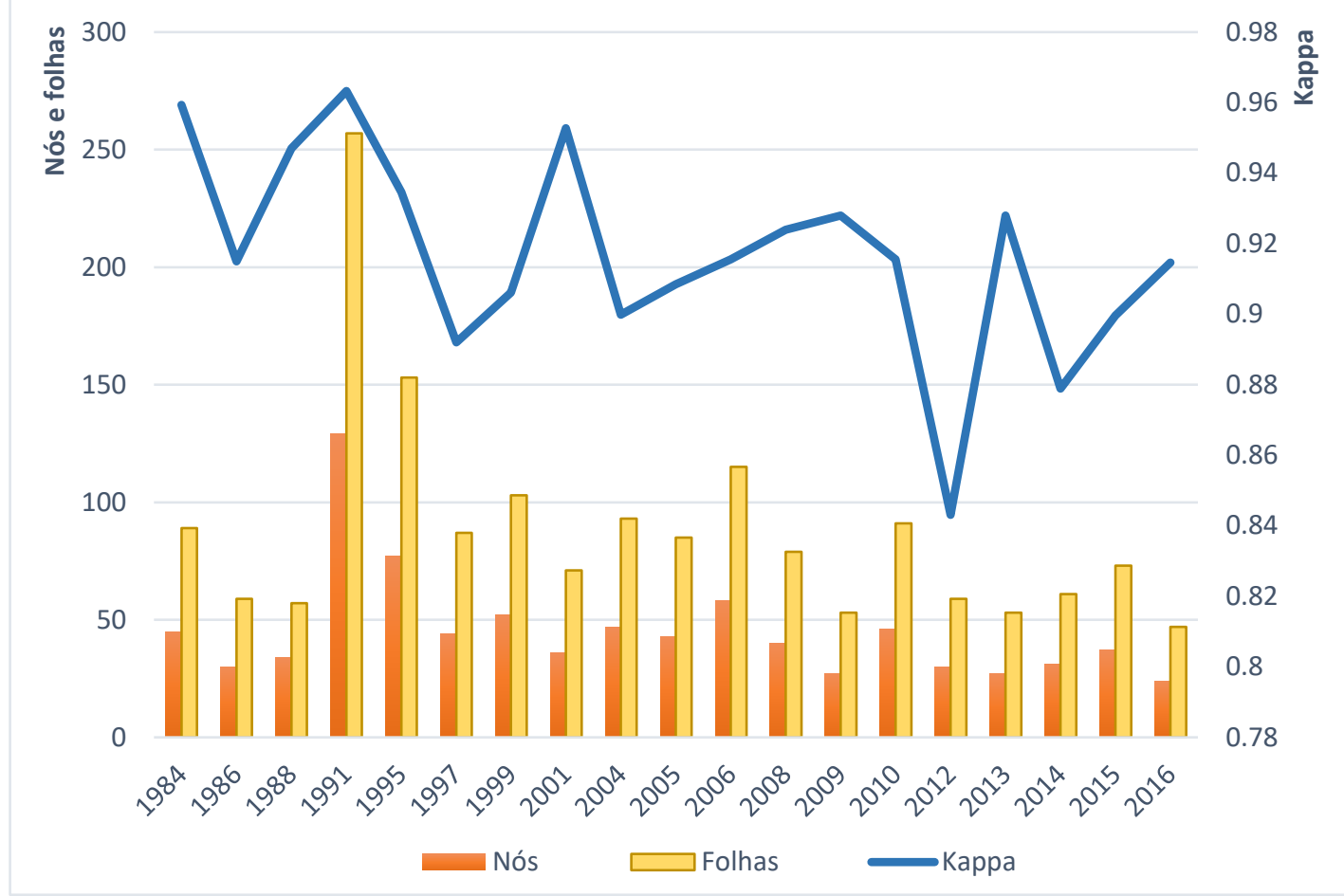

Figura 32 - Tamanho das regras de decisão de cada classificação

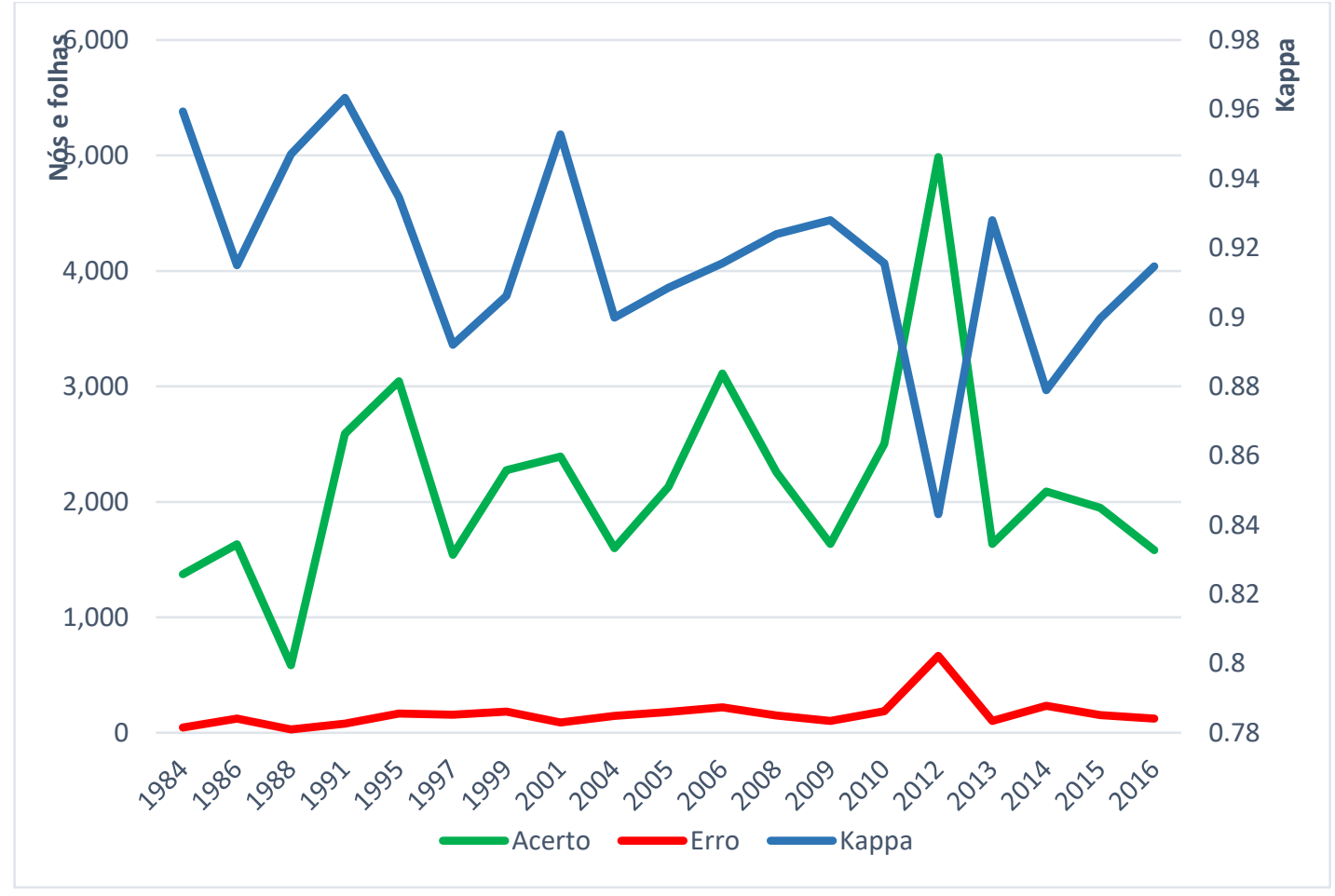

Figura 33 - Acerto, erro médio e Kappa das classificações 
Um arquivo de saída gerado por qualquer um dos algoritmos de classificação disponíveis no WEKA apresenta os resultados das medidas relativas à acurácia detalhada e à Matriz de Confusão da classificação. A acurácia detalhada é construída por medidas relacionadas à consistência dos preditivos conforme os parâmetros utilizados pelo classificador SIMPLECART do WEKA. As medidas utilizadas na Tabela 19 são apresentadas a seguir conforme referências no trabalho sobre mineração de dados associado ao WEKA (FRANK; HALL; WITTEN, 2016).

- PV. Positivo verdadeiro (preditivo positivo realmente positivo).

- FP. Falso positivo (preditivo positivo, mas na verdade negativo).

- FN. Falso negativo (preditivo negativo, mas na verdade positivo).

- NV. Negativo verdadeiro (preditivo negativo realmente negativo).

- Precisão: relação entre positivo verdadeiro e falso positivo, dada por:

$$
\text { Precisão: PV/PV + FP }
$$

- Sensitividade (Recall) Relação entre positivo verdadeiro e falso negativo, dada por:

$$
\text { Sensitividade: PV/PV + FN }
$$

- Média F. Combina os valores de precisão e Recall, dada pela equação

$$
\text { Média F: } 2 * \frac{\text { Precisão } * \text { Revocação }}{\text { Precisão + Revocação }}
$$

- Coeficiente de Correlação de Mathews (CCM). Medida de qualidade de classificações binárias, que pode ser calculada a partir da matriz de confusão através da equação:

$$
M C C=\frac{(P V * N V-F P * F N)}{\sqrt{(P V+F P)(P V+F N)(N V+F P)(N V+F N)}}
$$

- Característica de Operação do Receptor (COR). É uma curva que ilustra o desempenho de um classificador binário, mostrando a interação entre a fração de positivo verdadeiro e a fração de falso negativo.

- Curva de Precisão e Revocação (CPR). É uma outra curva que ilustra o desempenho de um classificador binário, mostrando a interação entre os valores de precisão e de Revocação. 
Tabela 19 - Acurácia detalhada da classificação de 2015

\begin{tabular}{|c|c|c|c|c|c|c|c|c|}
\hline Classe & $\begin{array}{l}\text { Taxa } \\
\text { PV }\end{array}$ & $\begin{array}{l}\text { Taxa } \\
\text { FP }\end{array}$ & Precisão & Recall & $\begin{array}{l}\text { Média } \\
\text { F }\end{array}$ & CCM & COR & CPR \\
\hline $\begin{array}{l}\text { Massa } \\
\text { d'água }\end{array}$ & 0,9130 & 0,0160 & 0,9020 & 0,9130 & 0,9080 & 0,8930 & 0,9900 & 0,9360 \\
\hline Área alagada & 0,7370 & 0,0220 & 0,7370 & 0,7370 & 0,7370 & 0,7150 & 0,9630 & 0,7140 \\
\hline $\begin{array}{l}\text { Deg. florestal } \\
\text { recente }\end{array}$ & 0,8420 & 0,0060 & 0,8510 & 0,8420 & 0,8470 & 0,8400 & 0,9830 & 0,7990 \\
\hline Sombra & 0,7330 & 0,0060 & 0,8410 & 0,7330 & 0,7830 & 0,7760 & 0,9830 & 0,8040 \\
\hline Nuvem & 1,0000 & 0,0000 & 1,0000 & 1,0000 & 1,0000 & 1,0000 & 1,0000 & 1,0000 \\
\hline Solo exposto & 0,8220 & 0,0010 & 0,9490 & 0,8220 & 0,8810 & 0,8810 & 0,9910 & 0,8400 \\
\hline $\begin{array}{l}\text { Pastagem e } \\
\text { campos }\end{array}$ & 0,9300 & 0,0130 & 0,9210 & 0,9300 & 0,9260 & 0,9130 & 0,9910 & 0,9230 \\
\hline SS1 (5 a 15) & 0,6780 & 0,0130 & 0,7290 & 0,6780 & 0,7030 & 0,6880 & 0,9760 & 0,7060 \\
\hline SS2 (15 a 30) & 0,5690 & 0,0030 & 0,8540 & 0,5690 & 0,6830 & 0,6900 & 0,9520 & 0,6800 \\
\hline $\begin{array}{l}\text { SS3 (F. } \\
\text { madura) }\end{array}$ & 0,9810 & 0,0470 & 0,9370 & 0,9810 & 0,9590 & 0,9280 & 0,9910 & 0,9790 \\
\hline $\begin{array}{l}\text { Média } \\
\text { ponderada }\end{array}$ & 0,8990 & 0,0270 & 0,8960 & 0,8990 & 0,8960 & 0,8770 & 0,9860 & 0,9040 \\
\hline
\end{tabular}

As medidas de acurácia apresentadas na Tabela 19 apontam grande acerto nas classes nuvem (com falso positivo 0), floresta madura (SS3) e solo exposto conforme a Figura 25 evidencia. Nenhuma classe apresentou baixo desempenho e 0 COR variou entre 0,9 e 1, enquanto o menor valor encontrado na medida CPR foi 0,68 para SS2 (floresta secundária 15 a 30 anos). Registra-se também que a Taxa PV apresentou os mesmos valores que a Revocação. Ao avaliar o conjunto das classes (Figura 25) verifica-se desempenho pior da veracidade das classes de estágio de sucessão (SS1 e SS2) e também as classes sombra e área alagada.

Os melhores resultados obtidos foram a elevada taxa de positivo verdadeiro (próximo a 1) e a baixa taxa de falso positivo (próximo a 0). Como ser verificado na Figura 34 , os bons resultados da média ponderada confirmam esta avaliação, mostrando que algumas classes tiveram resultado inferior (SS1, SS2 e área alagada) ao de outras classes com melhor resultado (nuvem, SS3, pastagem e campos, massa d'agua), além do bom desempenho da classe degradação florestal recente. Apesar de algumas classes com resultado abaixo do esperado a avaliação geral da 
classificação é positiva e a melhora dos resultados para floresta secundária poderão ser obtidos com o aperfeiçoamento da metodologia, ou o agrupamento de classes como SS1 e SS2 e a supressão da classe área alagada.

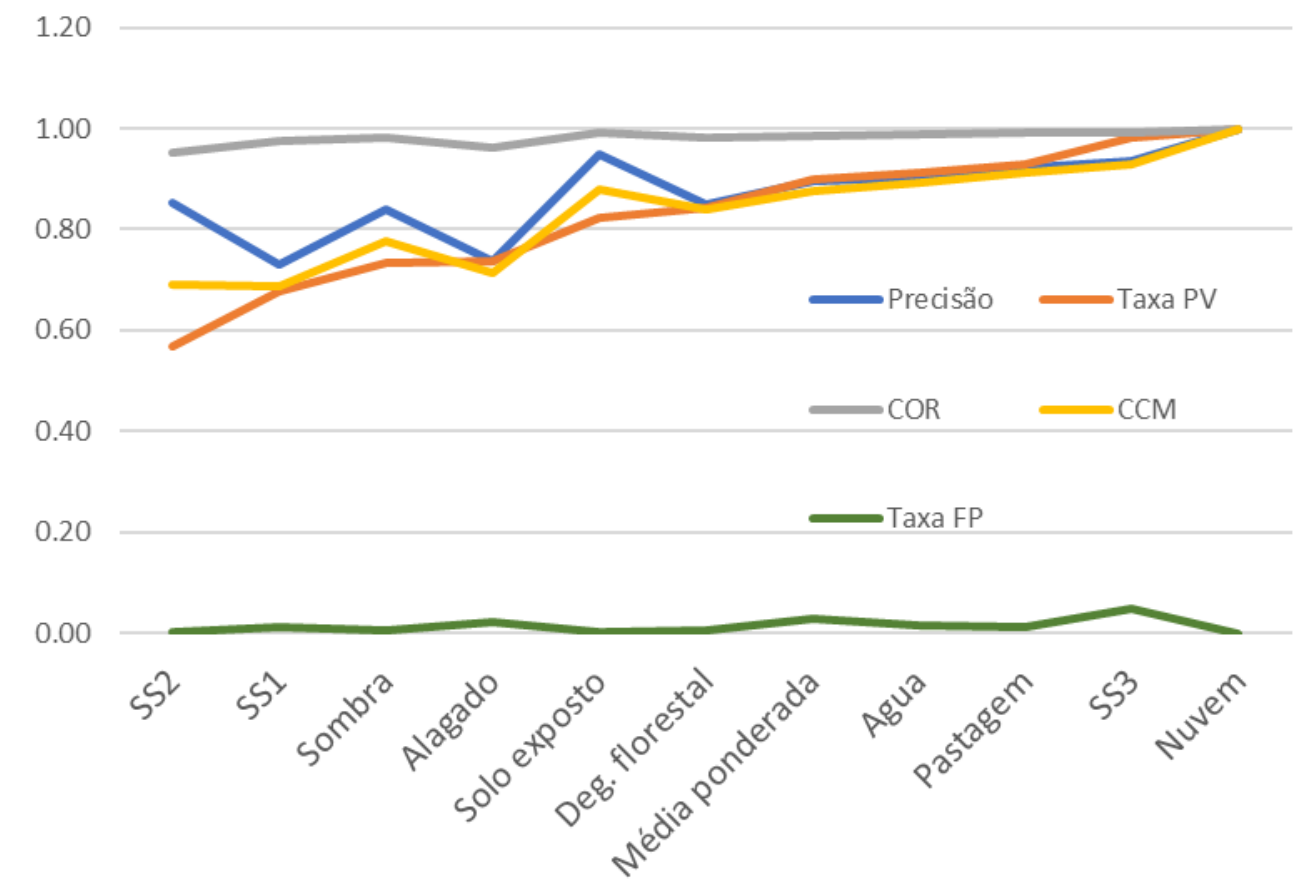

Figura 34 - Acurácia detalhada da classificação de 2015

Complementar aos dados de acurácia detalhada, a Matriz de Confusão é uma medida da classificação binária que mostra o número de classificações corretas versus as classificações preditas para cada classe. Nela, o número de acertos para cada classe localiza-se na diagonal principal da matriz, e os demais valores representam os erros de classificação; assim o valor zero significa a falta de erros para determinada classe.

A leitura diagonal da Matriz de Confusão (Tabela 20) permite verificar de forma objetiva o desempenho de cada classe e com quais outras ocorre conflito graças aos erros de classificação, como na Tabela 19 e na Figura 35, que apresentam a matriz de confusão relacionada a árvore de decisão gerada no WEKA (FRANK; HALL; WITTEN, 2016) a partir da classificação de 2015 e aplicada nos demais períodos analisados.

Os dados apresentados na matriz de confusão reforçam as conclusões iniciais obtidas das medidas de acurácia detalhada. Enquanto as classes nuvens e solo exposto destacaram-se pelo bom desempenho expresso na falta de conflitos com 
outras classes, as classes massa d'água e sombra tiveram comportamento esperado e conflito uma com a outra, conforme apresentado na Figura 35

Tabela 20 - Matriz de confusão da classificação de 2015

\begin{tabular}{|c|c|c|c|c|c|c|c|c|c|c|l|l|}
\hline $\mathbf{a}$ & $\mathbf{b}$ & $\mathbf{c}$ & $\mathbf{d}$ & $\mathbf{e}$ & $\mathbf{f}$ & $\mathbf{g}$ & $\mathbf{h}$ & $\mathbf{i}$ & $\mathbf{j}$ & onde & é & a classe \\
\hline 305 & 0 & 11 & 1 & 2 & 2 & 0 & 0 & 7 & 0 & $\mathrm{a}$ & $=\begin{array}{l}\text { Pastagem } \mathrm{e} \\
\text { campos }\end{array}$ \\
\hline 1 & 285 & 2 & 7 & 0 & 6 & 0 & 10 & 1 & 0 & $\mathrm{~b}$ & $=$ & Massa d'água \\
\hline 4 & 0 & 80 & 6 & 0 & 5 & 0 & 0 & 0 & 0 & $\mathrm{c}$ & $=\begin{array}{l}\text { Deg. Florestal } \\
\text { recente }\end{array}$ \\
\hline 7 & 9 & 0 & 129 & 0 & 17 & 0 & 4 & 9 & 0 & $\mathrm{~d}$ & $=$ & Área alagada \\
\hline 5 & 0 & 0 & 3 & 37 & 0 & 0 & 0 & 0 & 0 & $\mathrm{e}$ & $=$ & Solo exposto \\
\hline 0 & 1 & 1 & 6 & 0 & 936 & 0 & 0 & 8 & 2 & $\mathrm{f}$ & $=$ & SS3 (F. madura) \\
\hline 0 & 0 & 0 & 0 & 0 & 0 & 89 & 0 & 0 & 0 & $\mathrm{~g}$ & $=$ & Nuvem \\
\hline 0 & 21 & 0 & 5 & 0 & 1 & 0 & 74 & 0 & 0 & $\mathrm{~h}$ & $=$ & Sombra \\
\hline 9 & 0 & 0 & 13 & 0 & 10 & 0 & 0 & 78 & 5 & $\mathrm{i}$ & $=\begin{array}{l}\text { SS1 (F. 5 a 15 } \\
\text { anos) }\end{array}$ \\
\hline 0 & 0 & 0 & 5 & 0 & 22 & 0 & 0 & 4 & 41 & $\mathrm{j}$ & $=\begin{array}{l}\text { SS2 (F. 16 a 30 } \\
\text { anos) }\end{array}$ \\
\hline
\end{tabular}

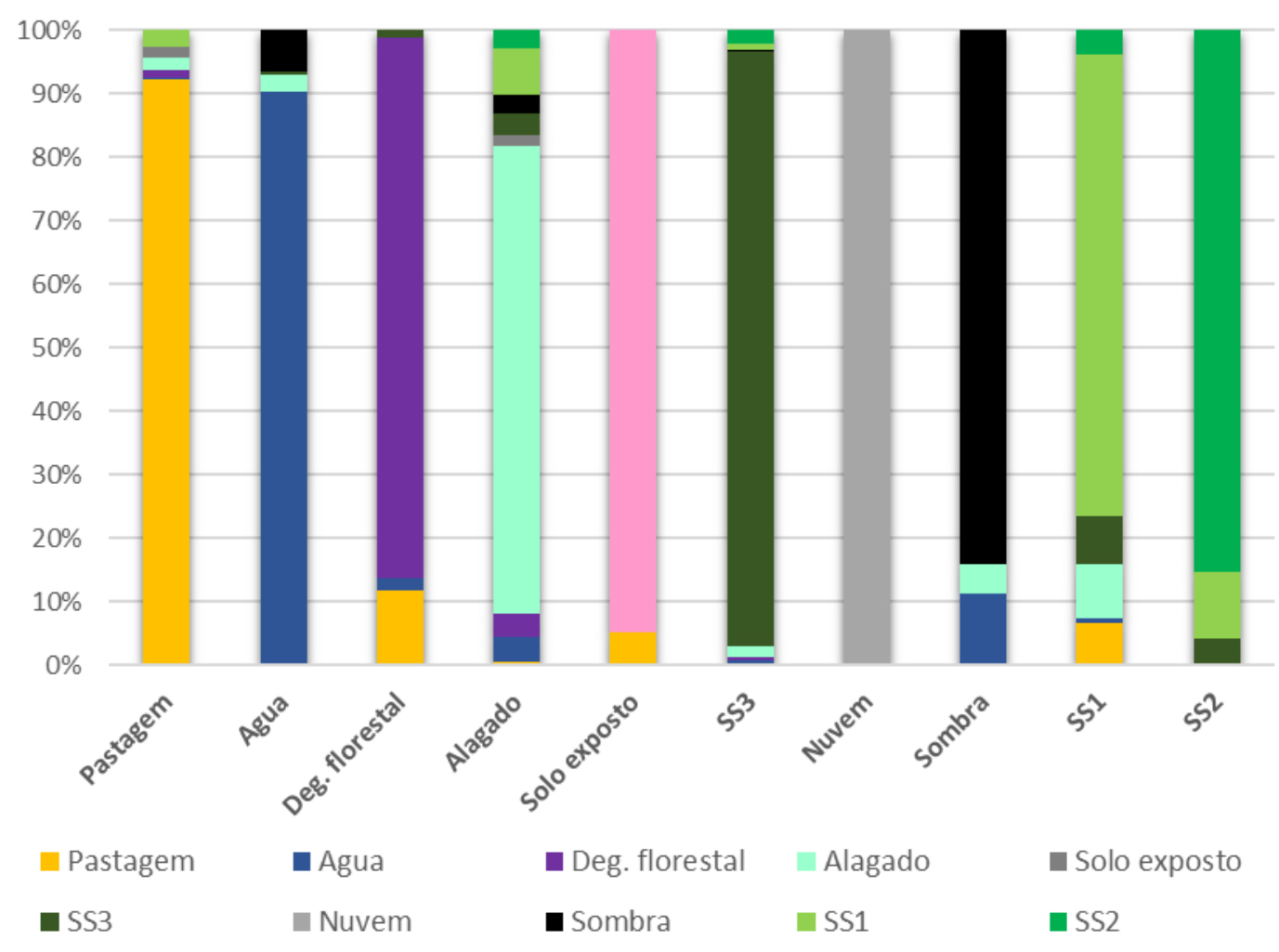

Figura 35 - Matriz de confusão da classificação de 2015 
As classes pastagem, degradação florestal recente e floresta madura (SS3) tiveram resultado satisfatório com poucos conflitos e acertos superiores a $90 \%$, enquanto o bom desempenho da classe degradação florestal é um fato inesperado que pode ser atribuído ao bom desempenho da segmentação para agregar pixels com características espectrais, geométricas, de vizinhança e textura próprias de florestas degradadas, além da coleta adequada de amostras. Em contraste, na classificação baseada em pixel este agrupamento ocorre baseado apenas em atributos espectrais e o refinamento de uma classificação para mapeamento da degradação florestal passa necessariamente pela intervenção do usuário, enquanto o uso combinado de GEOBIA e mineração de dados para construção de uma árvore de decisão dispensa o refinamento da classificação pelo usuário.

O desempenho das classes relacionadas à floresta secundária (SS1 e SS2) estão em conformidade com os dados de acurácia, que apontaram um acerto próximo a 70\% para SS1 e de $80 \%$ para SS2. São resultados satisfatórios, mas abaixo do esperado e que podem estar relacionados à coleta de amostras, seja pela distinção entre as duas classes ou pelas condições ambientais (clima e relevo) da área observada na hora da varredura do satélite, conforme informado anteriormente no item 5.3.3.1. Este último fator pode ser fundamental na coleta de amostras de florestas secundárias em imagens de diferentes períodos, mesmo utilizando imagens refletância de superfície.

Outra classe com desempenho regular foi a classe área alagada. A definição desta classe neste estudo considerou as formações pioneiras em área de planície fluvial (como a do rio Moju, um afluente de margem esquerda do rio Curuá-Una) e a planície de inundação do rio Amazonas. A várzea do rio Amazonas é um ambiente periodicamente alagado e abriga espécies macrófitas, herbáceas e arbóreas distintas das fitofisionomias de terra firme (encostas dissecadas, morrotes e platôs) como a floresta ombrófila densa, a floresta ombrófila aberta, e de ocorrência isolada na área de estudo, a Savana, conforme apresentado no item 2.2.

Apesar das diferenças específicas na morfologia do terreno e na composição das espécies em comparação com as espécies de regeneração em floresta ombrófila densa e floresta ombrófila aberta, estas características não estão claras em imagens de média resolução espacial $(30 \mathrm{~cm}$ por pixel) como os satélites LANDSAT e IRS-P6, pois a irradiância destas fisionomias distintas está em uma mesmo intervalo de níveis de brilho. A incorporação de outros atributos como a textura 
(GLCM) para esta classe não apresentaram maior relevância. Como será apresentado adiante na Tabela 22, os atributos dos índices de vegetação utilizados mostraram melhor performance que os atributos de textura (GLCM).

Uma solução possível com objetivo ao aprimoramento da abordagem é a aplicação desta classe apenas em máscara específica para este tipo de terreno, baseada em dados de elevação digital do terreno. Como visto na Figura 26, a maior confusão da classe área alagada ocorreu com a classe SS1. O mesmo critério foi aplicado neste estudo ao suprimir da primeira classificação as classes cerrado e agricultura anual (relativa ao plantio de grãos na região) e agrupá-las numa classe maior denominada pastagem e campos. Como resultado o acerto desta classe ficou acima de $90 \%$.

Em relação ao comportamento específico das classes de floresta secundária, a Figura 27Figura 37 e a Figura 38 mostram a distribuição dos valores máximos, mínimos e medianos para os atributos SAVI e NDWI apenas, que foram os mais representativos da árvore de decisão gerada no WEKA (FRANK; HALL; WITTEN, 2016), enquanto os demais atributos tiveram menor importância como mostra a Figura 29..

Os resultados sugerem que a seleção da época do ano pode ser um fator de influência. Como apresentado anteriormente na Tabela 9, a seleção das imagens procurou as mais representativas do período de seca na região de Santarém (de agosto a outubro), mas mesmo tendo este cuidado e utilizando a correção atmosférica superfície de refletância diferenças espectrais interferiram na análise das imagens.

Como pode ser verificado na Tabela 21, apenas em duas datas houve precipitação registrada na estação meteorológica de Belterra, e muito baixa. A precipitação média mensal apresenta valores mais discrepantes, especialmente em junho de 2010. A nebulosidade média apresentou valores na faixa de $4 \%$ a $6,5 \%$ e a temperatura média mensal oscilou entre $19^{\circ} \mathrm{C}$ e $23^{\circ} \mathrm{C}$.

O dado que pode apresentar alguma relação próxima da influência climática com valores espectrais nas imagens de satélite é a evaporação média mensal (piche) e o déficit com a precipitação média mensal. Conforme é possível verificar na Figura 36, algumas datas apresentaram déficit considerável como 1995, e excedente como em 2012. Em síntese, os dados mostram condições climáticas distintas, especialmente déficit hídrico, mas insuficientes para atribuir como principal responsável na discrepância entre os resultados das classificações. 
Tabela 21 - Dados da estação meteorológica de Belterra

\begin{tabular}{|c|c|c|c|c|c|c|}
\hline Data & $\begin{array}{c}\text { Precip. } \\
\text { Diária }\end{array}$ & $\begin{array}{c}\text { Evaporação } \\
\text { (Piche) }\end{array}$ & $\begin{array}{c}\text { Precipitação } \\
\text { Mensal, a p }\end{array}$ & $\begin{array}{c}\text { Déficit } \\
(\mathbf{E}-\mathbf{P})\end{array}$ & $\begin{array}{c}\text { Nebulos. } \\
\text { Média }\end{array}$ & $\begin{array}{c}\text { Temp. } \\
\text { Média } \\
\text { Mín. }\end{array}$ \\
\hline $31 / 08 / 2016$ & 0 & 134 & 28.9 & -105.1 & 5.451613 & 22.616129 \\
\hline $31 / 08 / 2015$ & 0 & 87.7 & 0 & -87.7 & 5.268817 & 22.464516 \\
\hline $30 / 09 / 2013$ & 1,6 & 85 & 14.9 & -70.1 & 6.155556 & 22.616667 \\
\hline $31 / 10 / 2014$ & 0 & 132.5 & 68.5 & -64 & 6.16129 & 23.058065 \\
\hline $31 / 08 / 2012$ & 0 & 78.5 & 31.9 & -46.6 & 5.387097 & 22.264516 \\
\hline $30 / 06 / 2010$ & 0 & 55.6 & 208.3 & 152.7 & 6.555556 & 22.36 \\
\hline $31 / 07 / 2009$ & 0 & 46.3 & 87.1 & 40.8 & 6.290323 & 21.793548 \\
\hline $30 / 11 / 2008$ & 0 & 81.8 & 82.7 & 0.9 & 6.416667 & 22.64 \\
\hline $31 / 08 / 2006$ & 0 & 72.7 & 18.6 & -54.1 & 5.301075 & 22.377419 \\
\hline $31 / 08 / 2005$ & 0 & 52.5 & 47.9 & -4.6 & 5.55914 & 22.287097 \\
\hline $31 / 08 / 2004$ & 0 & 54.4 & 55.3 & 0.9 & 5.225806 & 21.993548 \\
\hline $30 / 11 / 2001$ & 0 & 93.2 & 23.3 & -69.9 & 4.4 & 23.476667 \\
\hline $31 / 08 / 1999$ & 0 & 71.1 & 66.1 & -5 & 5.354839 & 21.290323 \\
\hline $31 / 07 / 1997$ & 0 & 35.8 & 25.3 & -10.5 & 5.870968 & 21.264516 \\
\hline $31 / 10 / 1995$ & 0 & 194.5 & 0 & -194.5 & 5.935484 & 21.887097 \\
\hline $31 / 07 / 1991$ & 0 & 59.3 & 92.9 & 33.6 & 6.258065 & 18.670968 \\
\hline $31 / 07 / 1988$ & 0 & 68.3 & 65.4 & -2.9 & 5.774194 & 19.083871 \\
\hline $31 / 08 / 1986$ & 0 & 116.6 & 14.4 & -102.2 & 3.763441 & 19.545161 \\
\hline $31 / 08 / 1984$ & 0,3 & 89.3 & 47.3 & -42 & 5.655914 & 19.567742 \\
\hline
\end{tabular}

Fonte: Série histórica da estação Belterra (PA) do Banco de dados meteorológicos para ensino e pesquisa (INMET, 2017).

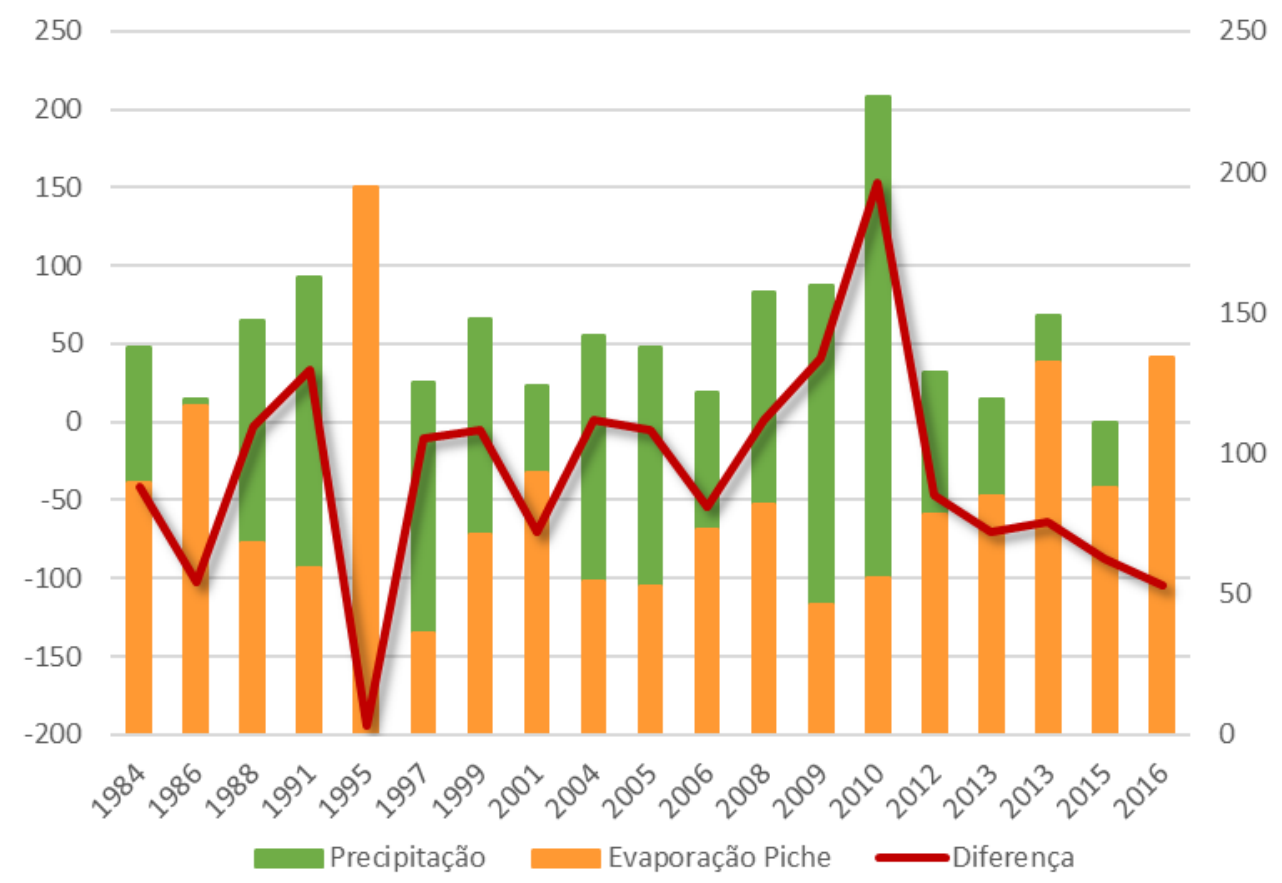

Em milimetros

Figura 36 - Precipitação e evaporação (piche) média mensal - 1984 a 2016 


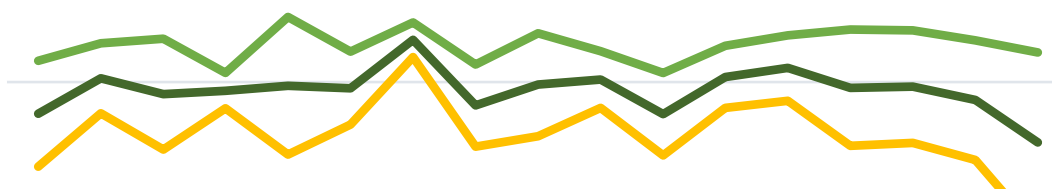

1.5000

1.2500

SS1 -

2.2500

2.0000

1.7500

1.5000

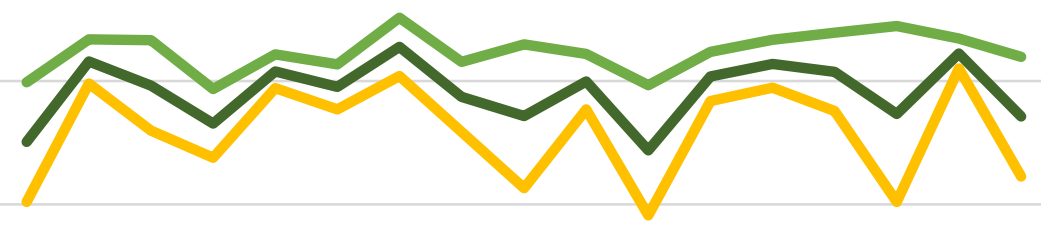

1.2500

SS2 -

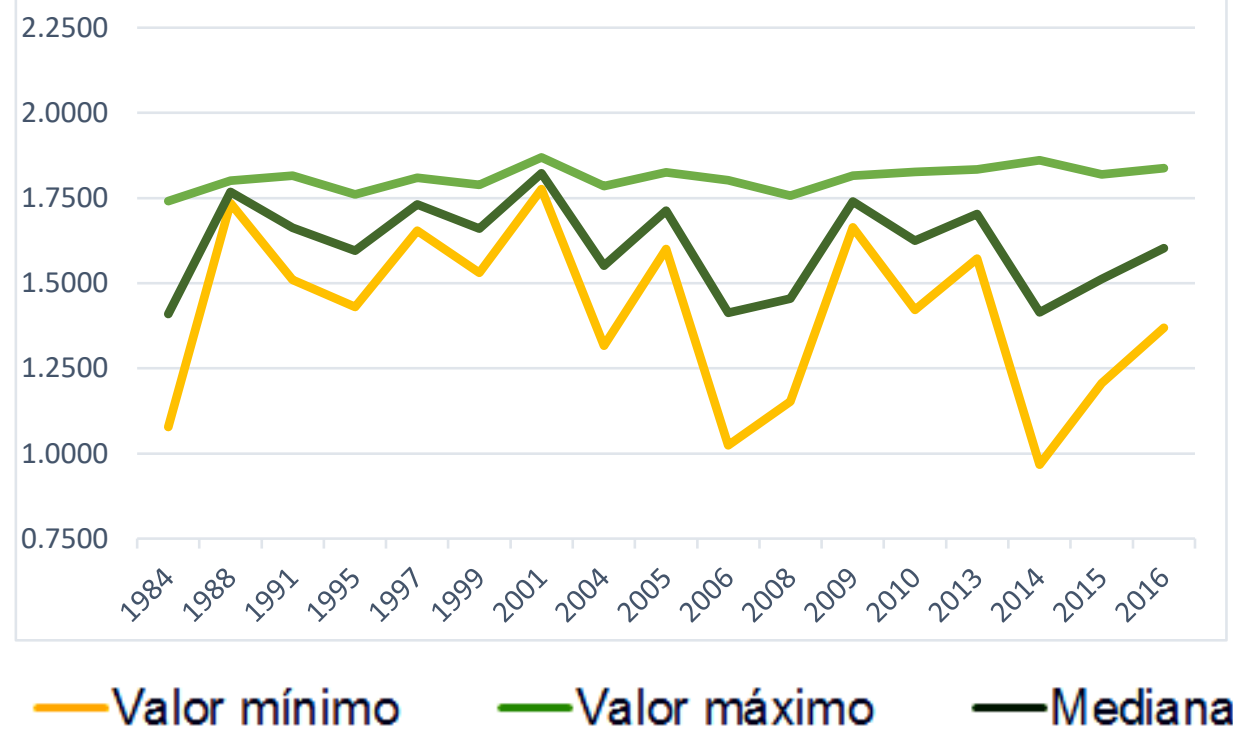

Figura 37 - Distribuição dos valores limiares usando SAVI 


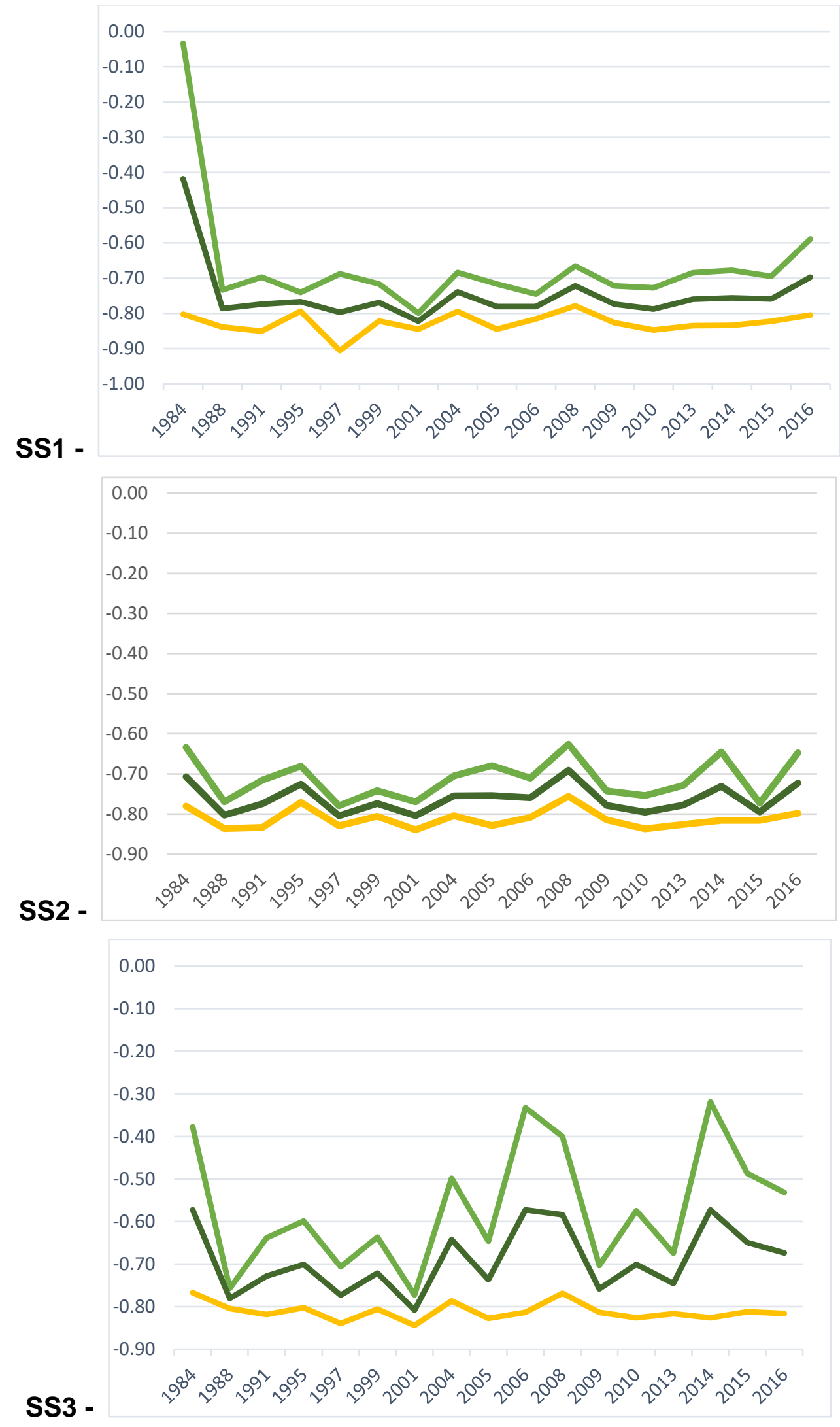

-Valor mínimo —Valor máximo —Mediana

Figura 38 - Distribuição dos valores limiares usando NDWI 
Ao analisar a correlação entre os atributos selecionados (SAVI, NDWI, NDMI, Média GLCM, Brilho, Máxima Diferença e Média das Bandas) foi encontrada forte correlação entre os valores medianos dos índices de vegetação SAVI e NDWI. Este comportamento também pode ser constatado no APÊNDICE 1, que mostra a recorrência destes índices de vegetação em nós e folhas da árvore de decisão.

$\mathrm{Na}$ Tabela 22 é apresentada a correlação entre os oito atributos selecionados para a análise da árvore de decisão. Os demais atributos espectrais e textura não foram considerados, dada a baixa relevância deles na árvore de decisão.

\section{Tabela 22 - Correlação dos valores medianos dos atributos analisados}

\begin{tabular}{|l|c|c|c|c|c|c|}
\hline Descrição do atributo & SS1 & \#ss1 & SS2 & \#ss2 & SS3 & \#ss3 \\
\hline MÉDIA_GLCM - MÉDIA_BANDAS & $-0,55$ & 4 & $-0,96$ & 2 & $-0,99$ & 1 \\
\hline MÉDIA_GLCM - MAX DIFF & $-0,55$ & 3 & $-0,96$ & 1 & $-0,99$ & 2 \\
\hline NDMI - BRILHO & $-0,27$ & 7 & $-0,67$ & 4 & $-0,83$ & 3 \\
\hline MÉDIA_BANDAS - MAX DIFF & $-0,32$ & 6 & $-0,63$ & 5 & $-0,76$ & 4 \\
\hline NDMI - MAX DIFF & $-0,26$ & 9 & $-0,49$ & 9 & $-0,75$ & 5 \\
\hline BRILHO - MAX DIFF & $-0,72$ & 1 & $-0,72$ & 3 & $-0,70$ & 6 \\
\hline NDWI - NDMI & 0,24 & 20 & $-0,53$ & 6 & $-0,68$ & 7 \\
\hline NDWI - NDVI & 0,29 & 21 & $-0,52$ & 7 & $-0,63$ & 8 \\
\hline SAVI - BRILHO & 0,29 & 22 & $-0,52$ & 8 & $-0,63$ & 9 \\
\hline NDMI - MÉDIA_GLCM & $-0,27$ & 8 & $-0,37$ & 12 & $-0,62$ & 10 \\
\hline NDVI - MÉDIA_BANDAS & $-0,01$ & 15 & $-0,43$ & 11 & $-0,59$ & 11 \\
\hline SAVI - NDVI & 0,64 & 27 & $-0,45$ & 10 & $-0,51$ & 12 \\
\hline NDMI - NDVI & $-0,07$ & 11 & 0,01 & 15 & $-0,32$ & 13 \\
\hline NDVI - MAX DIFF & $-0,03$ & 14 & 0,05 & 16 & $-0,13$ & 14 \\
\hline GLCM - BRILHO & $-0,60$ & 2 & 0,16 & 18 & $-0,13$ & 15 \\
\hline NDWI - MÉDIA_GLCM & 0,15 & 17 & 0,33 & 19 & 0,07 & 16 \\
\hline NDVI - BRILHO & $-0,03$ & 12 & 0,10 & 17 & 0,14 & 17 \\
\hline MÉDIA_BANDAS - BRILHO & $-0,44$ & 5 & $-0,07$ & 13 & 0,38 & 18 \\
\hline NDVI - MÉDIA_GLCM & $-0,03$ & 13 & 0,00 & 14 & 0,46 & 19 \\
\hline NDMI - MÉDIA_BANDAS & $-0,10$ & 10 & 0,63 & 24 & 0,54 & 20 \\
\hline NDWI - MAX DIFF & 0,16 & 18 & 0,58 & 21 & 0,67 & 21 \\
\hline NDWI - BRILHO & 0,01 & 16 & 0,45 & 20 & 0,69 & 22 \\
\hline NDWI - MÉDIA_BANDAS & 0,21 & 19 & 0,62 & 23 & 0,73 & 23 \\
\hline SAVI - MÉDIA_GLCM & 0,34 & 23 & 0,61 & 22 & 0,76 & 24 \\
\hline SAVI - MÉDIA_BANDAS & 0,55 & 25 & 0,78 & 27 & 0,85 & 25 \\
\hline SAVI - NDMI & 0,55 & 26 & 0,78 & 26 & 0,85 & 26 \\
\hline SAVI - MAX DIFF & 0,45 & 24 & 0,77 & 25 & 0,97 & 27 \\
\hline SAVI - NDWI & 1,00 & 28 & 1,00 & 28 & 1,00 & 28 \\
\hline
\end{tabular}

A Figura 39 apresenta a distribuição dos valores de correlação para os atributos selecionados e as três classes de sucessão secundária consideradas neste estudo. 

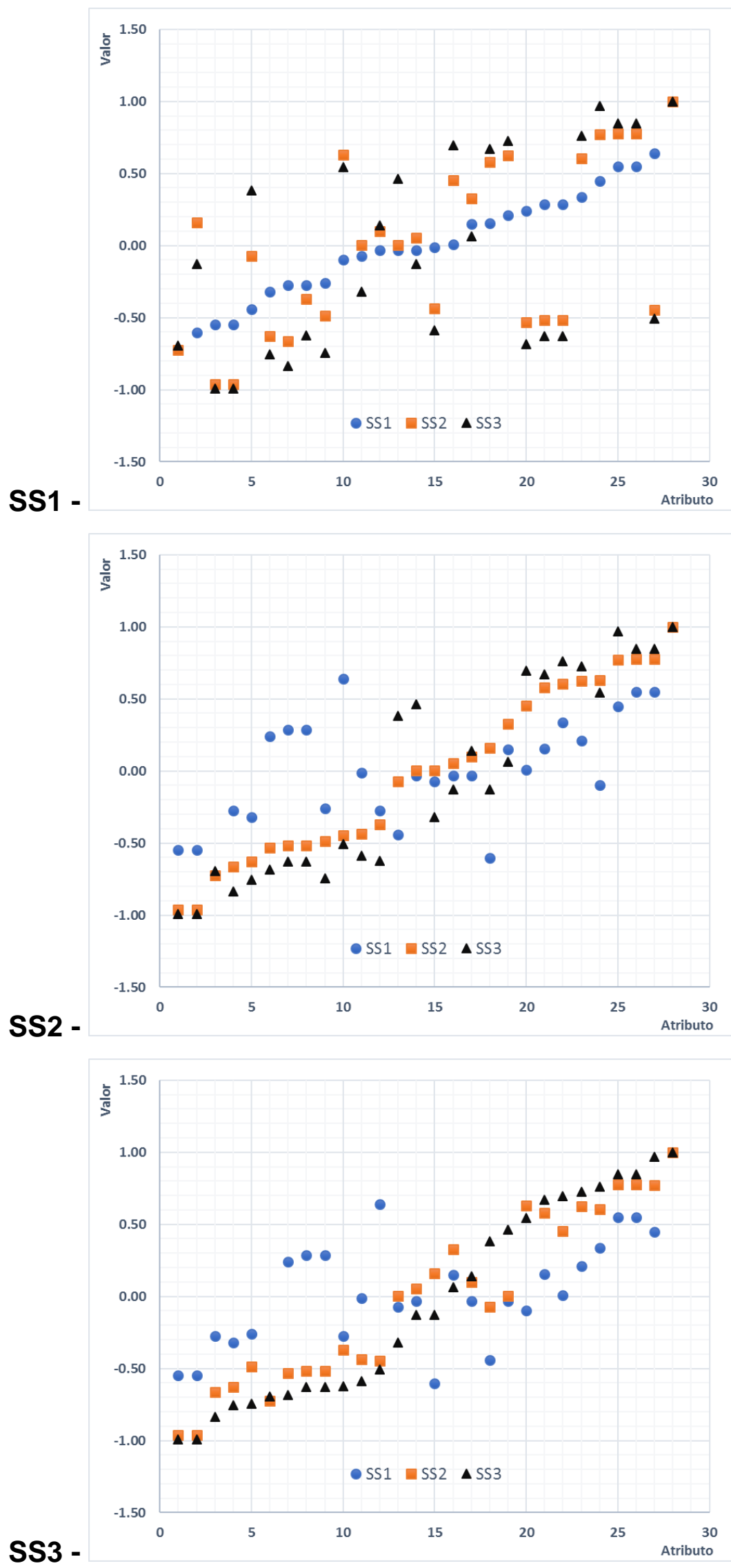

Eixo X são os atributos identificados pelas colunas "\#ss1", "\#ss2" e "\#ss3" da Tabela 22 Figura 39 - Correlação dos valores medianos dos atributos analisados 
É possível notar uma razoável proximidade dos valores mínimo, mediano e máximo, dos índices de vegetação SAVI e NDMI para a classe SS1 (floresta secundária de 5 a 15 anos) conforme verifica-se na Figura 27 e na Figura 28, respectivamente. Uma menor simetria pode ser verificada para a classe SS2 (floresta secundária de 15 a 30 anos) e para a classe SS3 (floresta madura). No entanto, para SS2 e SS3 há maior assimetria entre os valores mínimo e máximo, apesar da homogeneidade entre os valores máximos para cada período analisado.

Estes dados mostram a importância do uso das imagens refletância de superfície para este estudo e estudo de análise das mudanças no uso da terra. Sem obter as mesmas imagens da mesma fonte submetidas a um mesmo procedimento de correção atmosférica, a assimetria entre os valores mínimo, mediano e máximo seriam maiores. Cabe lembrar que nesta análise não foi considerada a imagem de 2012 do satélite IRS-P6 conforme informado no item 5.3.3.1.

Adicionalmente, para verificar a consistência da árvore de decisão foi calculada a correlação entre os valores medianos dos atributos de maior ocorrência na árvore de decisão para as classes SS1, SS2 e SS3. Como apresentado na Figura 29, a melhor correlação se dá entre a classe SS3 e a classe SS2, que entre a classe SS2 e a classe SS1, e depois de SS2 para SS3 e SS1, e ao considerar SS1 não há uma correlação clara. Nas três classes os valores próximos a 1 correspondem a relação dos índices SAVI e NDWI com os demais atributos considerados nesta análise, apresentado na Tabela 22.

O pior desempenho está na correlação entre os valores de textura GLCM com o valor médio das bandas para o pixel e para a máxima diferença do valor médio do pixel de cada banda. Este fraco desempenho pode ser atribuído a relação entre a resolução espacial das imagens utilizadas com as classes de mapeamento. Apesar de Haralick, Shanmugan e Dinstein (1973) ter apresentado o GLCM usando imagens de satélite LANDSAT em seu trabalho, os valores destes atributos não foram importantes à construção da árvore de decisão como foram os índices de vegetação como pode ser verificado no APÊNDICE 1.

Em síntese, os índices de vegetação SAVI e NDMI mostraram bons resultados na construção da árvore de decisão frente aos outros atributos espectrais e de textura utilizados. A aplicação destes índices gerou bons resultados para a identificação das classes com pouca ou nenhuma cobertura vegetal (nuvens, massa d'água, solo exposto, pastagem e campos), para a classe SS3 (floresta madura), e para a classe 
degradação florestal recente. Entretanto, o mesmo não verificado para as classes área alagada, SS1 e SS2 pois nenhum atributo empregado (índice de vegetação, textura ou aqueles relacionados ao brilho da banda) teve boa relação com a estrutura de uma floresta secundária e outras categorias de cobertura vegetal diferentes de uma floresta intocada ou madura.

A incorporação de dados relacionados à estrutura ou até mesmo o desenvolvimento de um índice de vegetação orientado à estrutura e não às condições de estresse hídrico da cobertura vegetal, poderiam contribuir ao aperfeiçoamento de uma abordagem para mapeamento de floresta secundária com imagens de média resolução espacial.

\subsection{ANÁLISE DOS RESULTADOS DA CLASSIFICAÇÃO}

Os resultados brutos da classificação produzida na árvore de decisão construída no ECOGNITION (TRIMBLE, 2016), surpreenderam pela grande variação de ocorrência das classes entre cada período analisado, particularmente a classe de floresta madura. Como apresentado anteriormente, esta classe teve bom acerto indicado pela acurácia detalhada e pela Matriz de Confusão, mas a cobertura significativa de nuvens e sombras em algumas cenas causaram esta alteração no resultado.

A classe Massa d'água apresentou variação significativa, embora esperada pois parte da área de estudo compreende a várzea do rio Amazonas, em terrenos periodicamente alagado e, a cada cheia, os lagos, furos e panarás podem assumir formas e dimensões distintas. Para os outros terrenos da várzea do rio Amazonas foi definida a classe Área Alagada, a qual também apresentou variação significativa de ocorrência para cada período analisado por essa razão, e também pelo baixo acerto ocasionado pela sobreposição com outras classes do mapeamento.

Por essas razões foi necessário realizar o refinamento da classificação em SIG conforme informado no item 5.3.9, através da criação de uma máscara para a classe floresta madura e da análise comparativa entre as classes SS1 e SS2 para cada período analisado. Os dados brutos da classificação são apresentados a seguir na Tabela 23. 
Tabela 23 - Dados brutos obtidos da classificação de cada período analisado

\begin{tabular}{|c|c|c|c|c|c|c|c|c|c|c|c|c|c|c|c|c|c|c|c|}
\hline Classe / Ano & 1984 & 1986 & 1988 & 1991 & 1995 & 1997 & 1999 & 2001 & 2004 & 2005 & 2006 & 2008 & 2009 & 2010 & 2012 & 2013 & 2014 & 2015 & 2016 \\
\hline Massas d'água & 1.657 & 261 & 393 & - & 4.737 & 2.428 & 926 & 1.980 & 3.409 & 5.417 & 4.799 & 5.993 & 13.678 & 119 & 2.067 & 3.759 & 4.478 & 2.308 & 20.803 \\
\hline Área alagada & 4.279 & 4.381 & 585 & 1.420 & 2.845 & 549 & 901 & 1.722 & 1.689 & 709 & 2.115 & 11.929 & 698 & 1.820 & 10.761 & 7.628 & 867 & 10.187 & 355 \\
\hline $\begin{array}{l}\text { Degradação } \\
\text { florestal recente }\end{array}$ & 44.937 & 5.803 & 21.154 & 383 & 20.442 & 10.696 & 17.528 & 20.919 & 9.584 & 1.767 & 19.357 & 18.644 & 6.679 & 3.376 & 16.014 & 9.337 & 1.809 & 22.118 & 286.459 \\
\hline Sombra & 36.454 & 1.489 & 398 & 6.611 & 12.939 & 1.020 & 386 & 6.115 & 3.631 & 6.609 & 22.573 & 27.467 & 652 & 992 & - & 22.946 & 84.451 & 12.167 & 70.389 \\
\hline Nuvem & 25.634 & 1.290 & 2.399 & 7.814 & 46.568 & 2.417 & 528 & 7.486 & 4.508 & 11.068 & 30.528 & 34.322 & 2.371 & 800 & - & 16.791 & 44.848 & 7.804 & 117.082 \\
\hline Solo exposto & 318 & 7.350 & 10.921 & 3.194 & 61.647 & 22.825 & 48.293 & 29.645 & 39.711 & 41.565 & 23.145 & 67.514 & 25.941 & 35.822 & 32.022 & 34.097 & 80.955 & 24.771 & 35.321 \\
\hline $\begin{array}{l}\text { Pastagem e } \\
\text { campos }\end{array}$ & 28.407 & 31.135 & 64.561 & 47.277 & 141.160 & 79.383 & 70.893 & 192.052 & 130.558 & 111.021 & 104.410 & 133.635 & 147.812 & 139.531 & 136.222 & 146.455 & 98.375 & 153.167 & 142.582 \\
\hline $\begin{array}{l}\text { SS1 (F. secundaria } \\
\text { 5a } 15 \text { anos) }\end{array}$ & 66.830 & 89.583 & 89.364 & 83.968 & 6.278 & 99.176 & 69.576 & 8.848 & 27.599 & 59.184 & 58.299 & 46.274 & 59.759 & 45.148 & 40.783 & 84.963 & 39.560 & 132.062 & 98.661 \\
\hline $\begin{array}{l}\text { SS2 (F. secundária } \\
16 \text { a } 30 \text { anos) }\end{array}$ & 98.129 & 130.077 & 76.932 & 127.627 & 56.712 & 166.754 & 81.269 & 64.972 & 99.117 & 102.044 & 68.501 & 46.968 & 100.560 & 100.271 & 80.392 & 152.190 & 72.201 & 108.433 & 22.670 \\
\hline $\begin{array}{l}\text { SS3 (Floresta } \\
\text { madura) }\end{array}$ & 2.785 .559 & 1.794 .603 & 1.783 .467 & 2.746 .913 & 1.676 .383 & 1.635 .711 & 1.719 .085 & 1.675 .659 & 1.676 .281 & 1.645 .873 & 2.556 .979 & 2.466 .727 & 2.483 .574 & 1.614 .954 & 1.600 .324 & 1.400 .577 & 1.419 .024 & 1.220 .730 & 537.440 \\
\hline $\begin{array}{l}\text { Não } \\
\text { classificado }\end{array}$ & 3 & 17 & 48 & 4 & 5 & 57 & 20 & 7 & 14 & 322 & 14 & 30 & 6 & 6 & 33 & 28 & 65 & 12,116 & 2 \\
\hline
\end{tabular}

Dados em hectares 
Conforme apresentado na Tabela 23, os dados brutos das classes relacionadas ao uso da terra e à cobertura vegetal apresentaram grande variação entre os períodos analisados, embora tenha se construído uma árvore de decisão para automatizar o processo e procurar reduzir a possibilidade desta variação ocorrer. Esta variação é representada na Figura 42, em que se verifica a assimetria em todas as classes de sucessão secundária: 5 a 15 anos (SS1), 15 a 30 anos (SS2) e floresta madura (SS3).

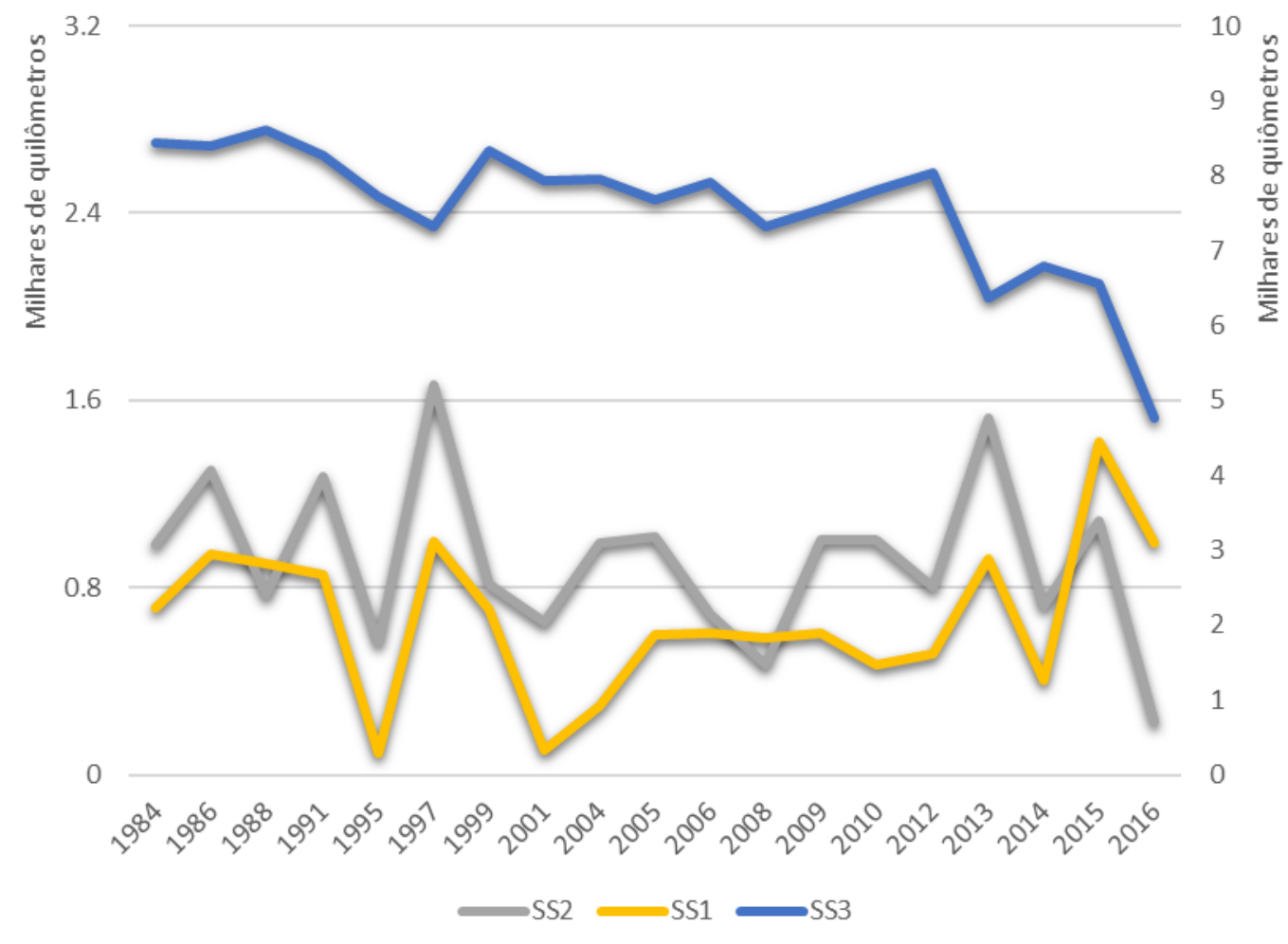

Figura 40 - Evolução das classes de sucessão secundária (dados brutos)

No entanto, esta variação pode estar relacionada a quantidade de classes adotada (11 classes), ou a adoção de uma classe que trouxe prejuízo à classificação como é o caso da classe área alagada. Como exemplo, na Figura 42 é possível observar pouca variação entre as classes Solo Exposto e Pastagem ao longo de todos os períodos analisado, assim como entre as classes SS1 e SS2.

Para melhor compreensão da evolução da sucessão secundária ao longo dos períodos analisado foi utilizado um aplicativo SIG para, primeiro, agrupar as classes SS1 e SS2 numa única classe e em seguida aplicar a intersecção entre a sucessão secundária total de cada período com o período anterior, até 1984. Com esta análise foi possível verificar que a regeneração florestal é interrompida em até 5 anos após abandono, sendo substituída por pastagem ou agricultura anual. 
Em oposição aos dados da Tabela 23, na Tabela 24 é possível verificar que a ocorrência de regeneração florestal para cada período analisado é restrita aos cinco primeiros anos de abandono, o pousio, sendo interrompida e substituída por pastagem ou agricultura anual, como ilustrado na Figura 42. De acordo com os dados da Tabela 24, dos cerca de 78 mil hectares de floresta secundária contabilizados na área de estudo apenas 19 hectares podem ser considerados como remanescentes de uma sucessão secundária em curso desde 1984.

Os dados da Tabela 24 e da Tabela 25, ambas apresentadas na sequência mostram a redução considerável da extensão da classe floresta madura, de 863 mil hectares em 1984 para 306 mil hectares em 2016 e, apesar de alguma assimetria que não pode ser associada à acurácia da classificação, mas também a própria dinâmica de limpeza de pousio, uma estabilização entre 70 mil e 150 mil hectares, enquanto a soma dos resultados das classes solo exposto e pastagem (dados da Tabela 23) mostra um crescimento gradual e uma estabilização em torno de 200 mil hectares como ilustrado na Figura 42, com destaque para crescimento exponencial da degradação florestal em 2016 (dados da Tabela 23).

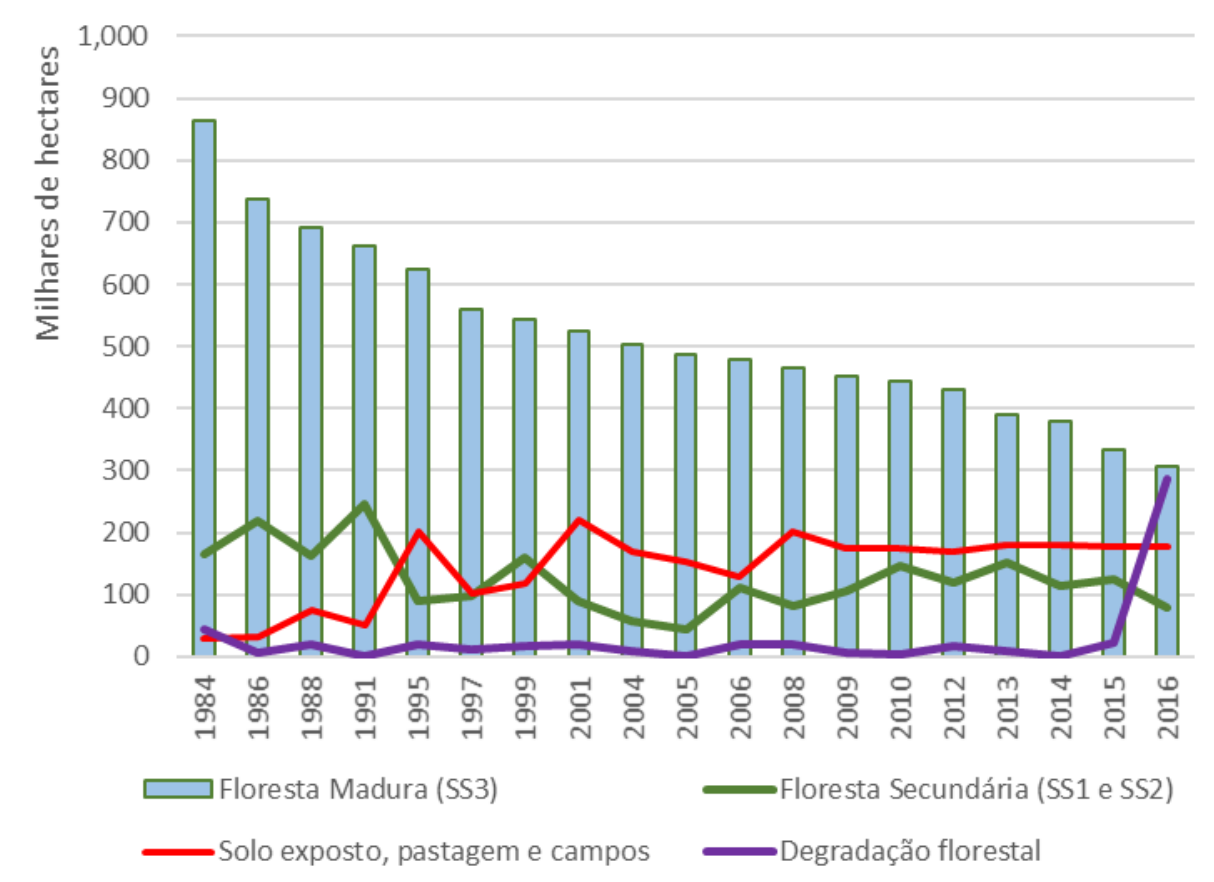

Figura 41 - Evolução das classes de cobertura vegetal e uso da terra 
Tabela 24 - Ocorrência de floresta secundária para cada período analisado

\begin{tabular}{|c|c|c|c|c|c|c|c|c|c|c|c|c|c|c|c|c|c|c|c|}
\hline Ano & 1984 & 1986 & 1988 & 1991 & 1995 & 1997 & 1999 & 2001 & 2004 & 2005 & 2006 & 2008 & 2009 & 2010 & 2012 & 2013 & 2014 & 2015 & 2016 \\
\hline 1984 & 164.959 & 90.971 & 59.913 & 47.489 & 11.922 & 9.700 & 5.408 & 2.893 & 1.527 & 867 & 494 & 382 & 271 & 208 & 93 & 73 & 56 & 36 & 19 \\
\hline 1986 & 90.971 & 219.659 & 103.082 & 79.855 & 18.759 & 15.142 & 8.734 & 4.348 & 2.277 & 1.361 & 670 & 516 & 364 & 275 & 117 & 86 & 66 & 44 & 22 \\
\hline 1988 & 59.913 & 103.082 & 162.995 & 119.963 & 24.127 & 18.819 & 10.439 & 5.007 & 2.545 & 1.538 & 744 & 568 & 404 & 301 & 131 & 94 & 71 & 48 & 23 \\
\hline 1991 & 47.489 & 79.855 & 119.963 & 247.307 & 34.796 & 25.768 & 14.046 & 6.327 & 3.201 & 1.953 & 893 & 655 & 469 & 351 & 158 & 114 & 85 & 60 & 24 \\
\hline 1995 & 11.922 & 18.759 & 24.127 & 34.796 & 89.604 & 39.044 & 19.683 & 8.663 & 4.461 & 2.739 & 1.156 & 841 & 597 & 449 & 216 & 159 & 114 & 85 & 28 \\
\hline 1997 & 9.700 & 15.142 & 18.819 & 25.768 & 39.044 & 158.784 & 100.474 & 27.431 & 13.263 & 8.669 & 3.318 & 2.010 & 1.495 & 1.087 & 519 & 341 & 210 & 157 & 43 \\
\hline 1999 & 5.408 & 8.734 & 10.439 & 14.046 & 19.683 & 100.474 & 158.784 & 35.487 & 16.740 & 10.746 & 4.165 & 2.428 & 1.831 & 1.325 & 641 & 426 & 257 & 182 & 52 \\
\hline 2001 & 2.893 & 4.348 & 5.007 & 6.327 & 8.663 & 27.431 & 35.487 & 90.156 & 30.259 & 16.527 & 6.659 & 3.607 & 2.728 & 1.887 & 857 & 559 & 334 & 241 & 63 \\
\hline 2004 & 1.527 & 2.277 & 2.545 & 3.201 & 4.461 & 13.263 & 16.740 & 30.259 & 57.533 & 62.630 & 27.356 & 11.389 & 8.531 & 5.927 & 2.851 & 1.819 & 916 & 655 & 148 \\
\hline 2005 & 867 & 1.361 & 1.538 & 1.953 & 2.739 & 8.669 & 10.746 & 16.527 & 62.630 & 44.400 & 64.575 & 22.655 & 16.505 & 11.500 & 5.468 & 3.738 & 1.745 & 1.268 & 309 \\
\hline 2006 & 494 & 670 & 744 & 893 & 1.156 & 3.318 & 4.165 & 6.659 & 27.356 & 64.575 & 110.030 & 38.500 & 24.918 & 16.447 & 8.092 & 5.645 & 2.518 & 1.878 & 458 \\
\hline 2008 & 382 & 516 & 568 & 655 & 841 & 2.010 & 2.428 & 3.607 & 11.389 & 22.655 & 38.500 & 106.019 & 47.906 & 29.275 & 13.732 & 9.434 & 4.023 & 2.941 & 705 \\
\hline 2009 & 271 & 364 & 404 & 469 & 597 & 1.495 & 1.831 & 2.728 & 8.531 & 16.505 & 24.918 & 47.906 & 106.019 & 77.823 & 33.005 & 22.343 & 8.548 & 6.161 & 1.529 \\
\hline 2010 & 208 & 275 & 301 & 351 & 449 & 1.087 & 1.325 & 1.887 & 5.927 & 11.500 & 16.447 & 29.275 & 77.823 & 146.855 & 53.441 & 35.006 & 12.994 & 9.269 & 2.382 \\
\hline 2012 & 93 & 117 & 131 & 158 & 216 & 519 & 641 & 857 & 2.851 & 5.468 & 8.092 & 13.732 & 33.005 & 53.441 & 119.321 & 72.383 & 23.329 & 15.471 & 4.066 \\
\hline 2013 & 73 & 86 & 94 & 114 & 159 & 341 & 426 & 559 & 1.819 & 3.738 & 5.645 & 9.434 & 22.343 & 35.006 & 72.383 & 152.220 & 58.189 & 32.949 & 8.446 \\
\hline 2014 & 56 & 66 & 71 & 85 & 114 & 210 & 257 & 334 & 916 & 1.745 & 2.518 & 4.023 & 8.548 & 12.994 & 23.329 & 58.189 & 113.455 & 53.215 & 13.609 \\
\hline 2015 & 36 & 44 & 48 & 60 & 85 & 157 & 182 & 241 & 655 & 1.268 & 1.878 & 2.941 & 6.161 & 9.269 & 15.471 & 32.949 & 53.215 & 124.660 & 46.152 \\
\hline 2016 & 19 & 22 & 23 & 24 & 28 & 43 & 52 & 63 & 148 & 309 & 458 & 705 & 1.529 & 2.382 & 4.066 & 8.446 & 13.609 & 46.152 & 78.078 \\
\hline
\end{tabular}

Dados em hectares 
Tabela 25 - Cobertura florestal para cada período analisado conforme o estágio de sucessão

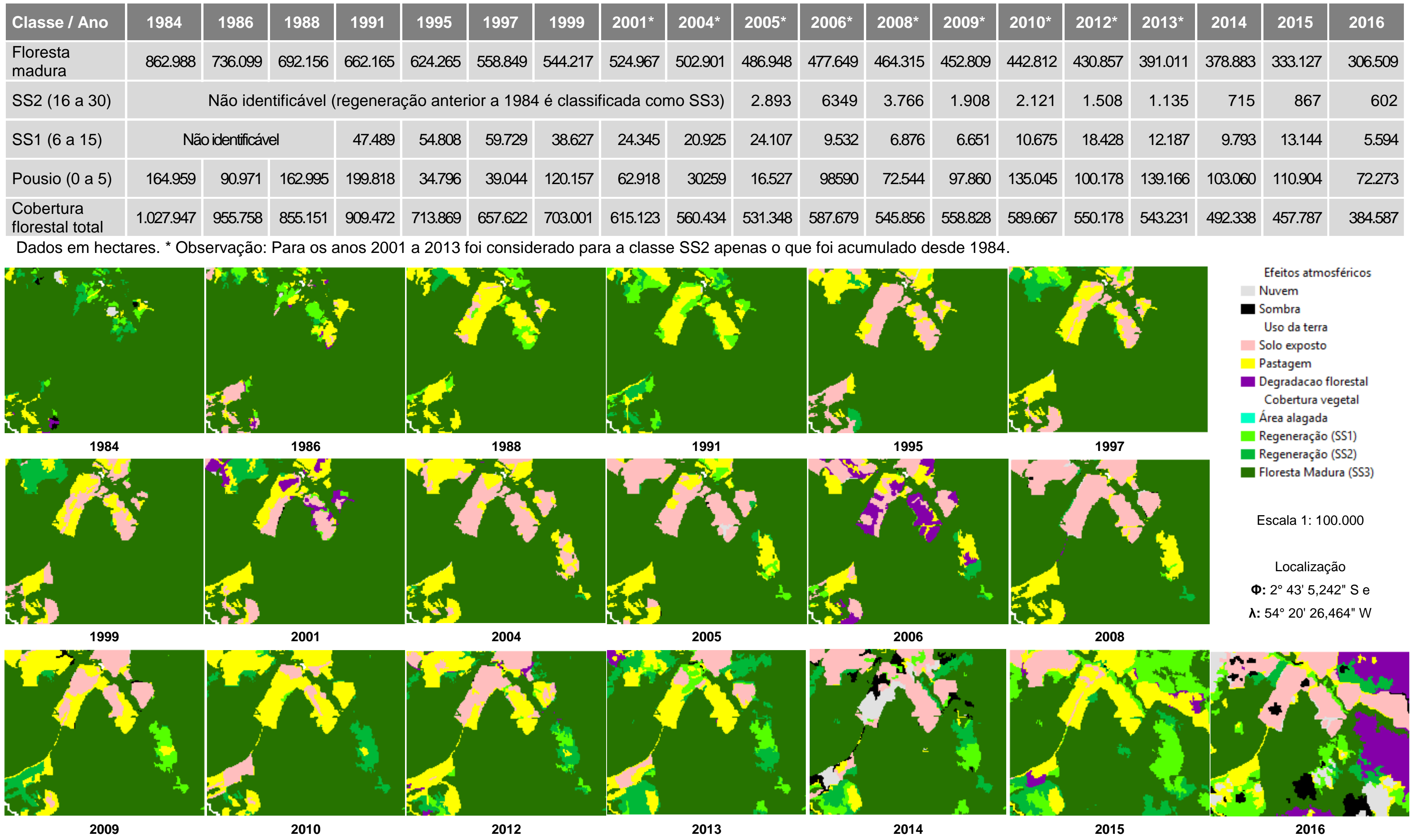

Figura 42 - Exemplo de resultados da classificação dos períodos analisados 
A Figura 31 apresenta um fragmento com área aproximada de $90 \mathrm{~km}^{2}$, situado há cerca de 10 quilômetros ao norte da barragem da UHE Curuá-Una. A escolha desta área considerou uma localidade que melhor representasse a transição entre as classes de sucessão secundária, desmatamento, degradação florestal (2016), e a alta rotatividade entre solo exposto e pastagem.

Ao estudar a regeneração florestal em Machadinho d'Oeste (RO), Batisttela e Moran (2005) verificam também a alta rotatividade entre o pousio ou o abandono da terra após o desmatamento da floresta madura, o solo exposto (preparação para plantio) e a formação de pastagem ou cultivo de grãos. Os resultados deste estudo sugerem a mesma dinâmica de uso da terra na região de Santarém, como pode ser verificado na Tabela 21 e na Tabela 22: a variação anual entre as classes solo exposto e pastagem, e um intervalo um pouco maior (até 5 anos) para a sucessão secundária conforme bem ilustrado na Figura 31. As possíveis trajetórias de alteração do uso da terra foram sintetizadas por Batisttela e Moran (2005) em um diagrama reproduzido na Figura 32.

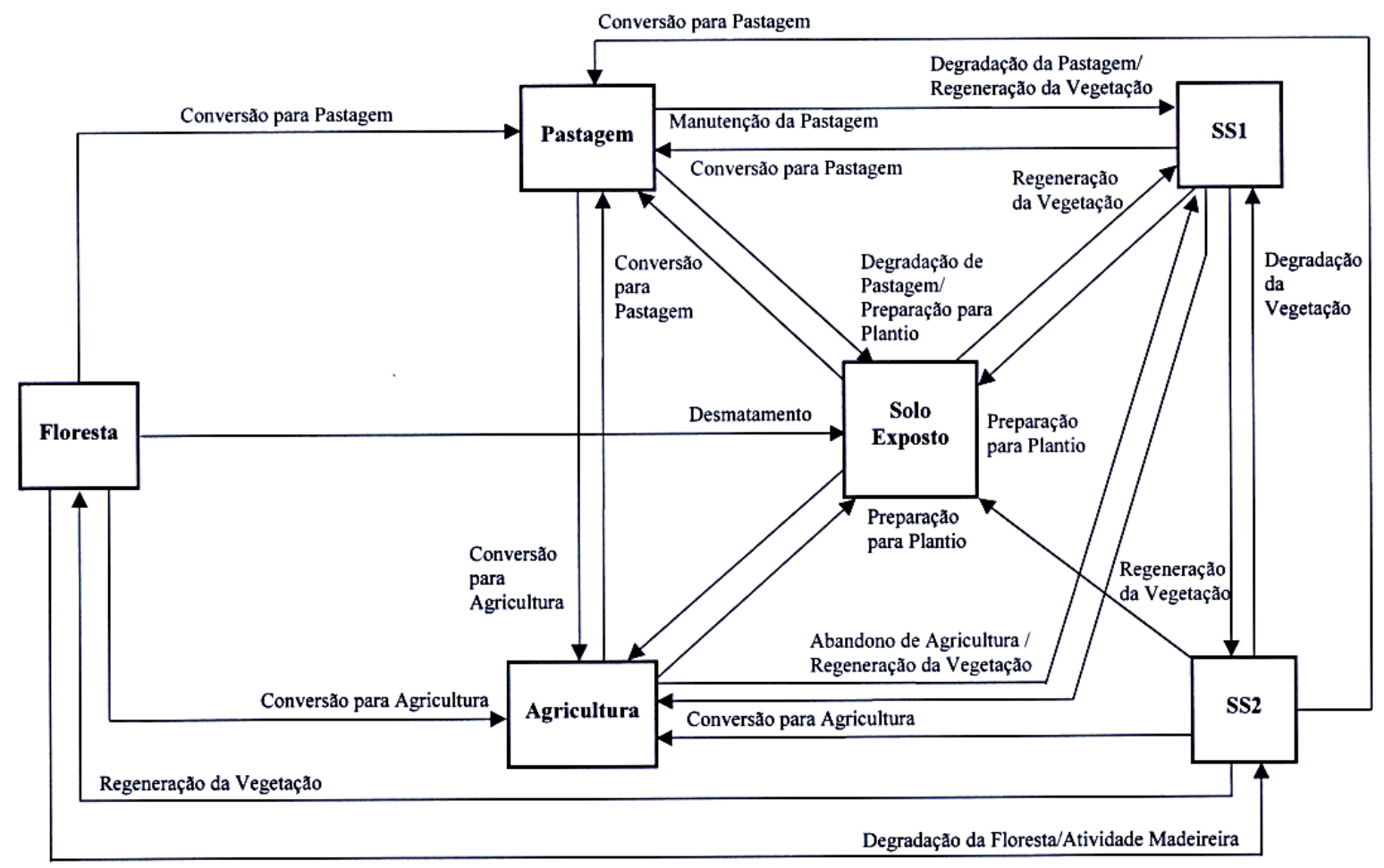

Figura 43 - Trajetórias de alteração da paisagem

Fonte: Batisttela e Moran (2005).

Nas páginas seguintes são apresentados os mapas referentes à classificação de 1986 (Mapa 4), 1995 (Mapa 5), 2006 (Mapa 6), 2012 (Mapa 7), 2015 (Mapa 8) e 2016 (Mapa 9). Para efeito de síntese procurou-se apresentar apenas os mapas que 
cobrissem cada década ao invés de um mapa de cada período, com exceção ao mapa referente à classificação de 2012 por duas razões específicas: primeiro pois foi produzido a partir da classificação da mais recente imagem de satélite sem nuvens; segundo porque foi o ano de aprovação da Lei 12.727 (BRASIL, 2012). Assim, torna- se possível acompanhar a evolução das florestas secundárias e das mudanças no uso da terra para cada década e, também, desde a aprovação do Novo Código Florestal até o ano de 2016.

Ressalta-se novamente que a classificação de 2012 foi produzida sem a árvore de decisão elaborada para a classificação das imagens LANDSAT por tratar-se de uma imagem obtida por outro satélite (IRS-P6) e submetida a outro algoritmo de correção atmosférica, como informado no item 5.3.3.1, o FLAASH do aplicativo ENVI (EXILIS, 2015). Até o fechamento deste trabalho não foi encontrado método de correção atmosférica da imagem do satélite IRS-P6 compatível com o algoritmo LEDAPS (USGS, 2016).

Conforme informado no item 5.3.9, foi necessário elaborar uma máscara para a classe floresta madura (SS3) com uso de SIG, ou seja, uma adaptação da técnica utilizada por Carreiras et al. (2014) com o objetivo de reduzir as variações provocadas pela presença de nuvens e sombras de nuvens para a análise evolução desta classe para os períodos analisados. Na classificação da imagem de 2016 não foi aplicada esta técnica pois o procedimento baseia-se na criação de uma máscara da classificação mais recente para aplicação na classificação da imagem imediatamente anterior.

Como resultado verifica-se uma progressiva fragmentação da classe floresta madura em todos os períodos analisados com ápice em 2016, ano em que as cicatrizes de queimada e corte seletivo ilegal levaram a fragmentação de 286 mil hectares de floresta madura (Tabela 23) mapeados apesar da grande cobertura de nuvens no período. Destaca-se também o incremento das áreas classificadas como pastagem e campos no decorrer dos últimos 30 anos, conforme o esperado em função da expansão das atividades agropecuárias na região de Santarém. 


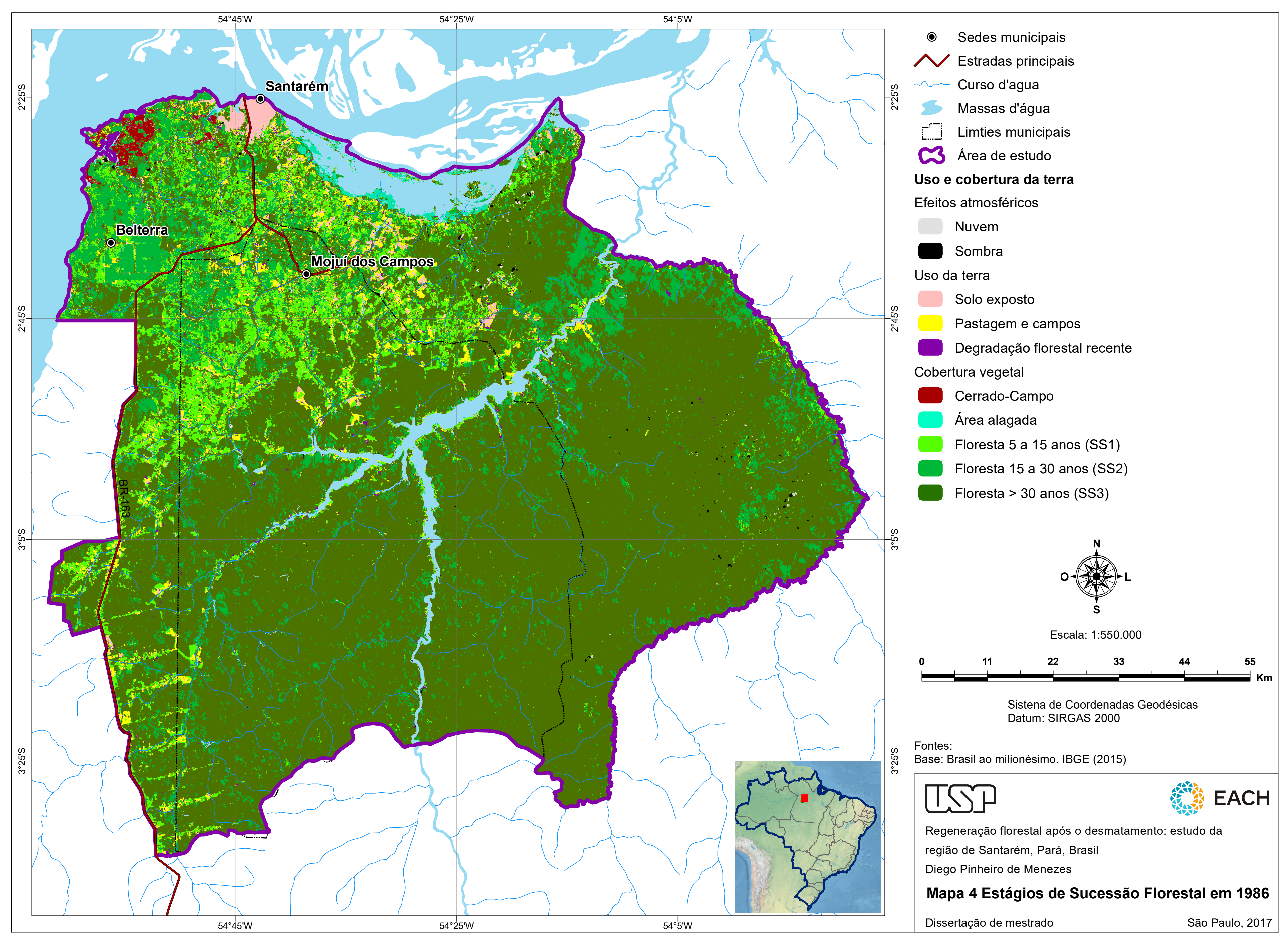




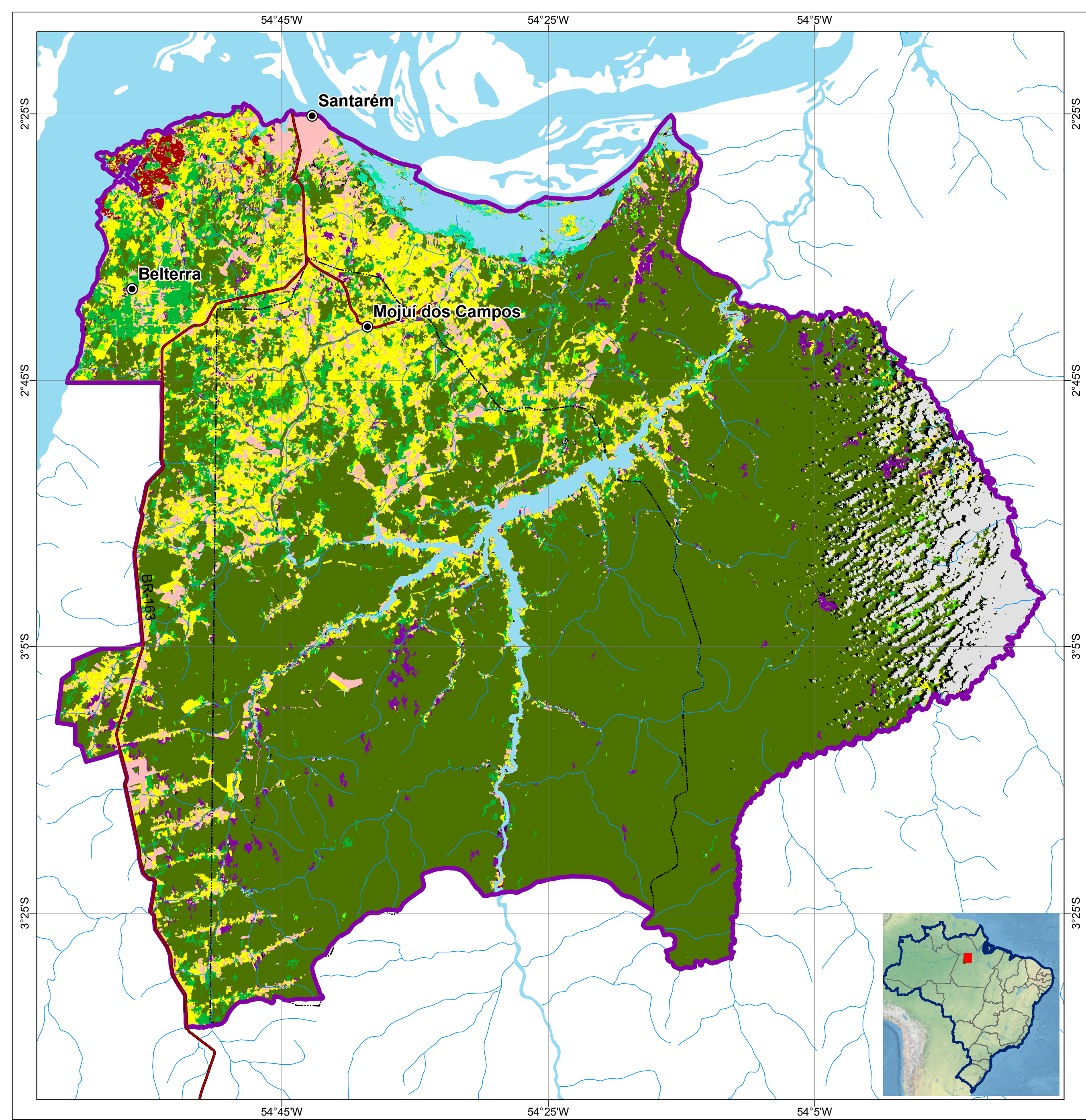

- Sedes municipais

Estradas principais

$\sim$ Curso d'agua

3 Massas d'água

Limties municipais

$\checkmark 3$ Área de estudo

Uso e cobertura da terra

Efeitos atmosféricos

Nuvem

Sombra

Uso da terra

Solo exposto

Pastagem e campos

Degradação florestal recente

Cobertura vegetal

Cerrado-Campo

Área alagada

Floresta 5 a 15 anos (SS1)

Floresta 15 a 30 anos (SS2)

Floresta $>30$ anos (SS3)

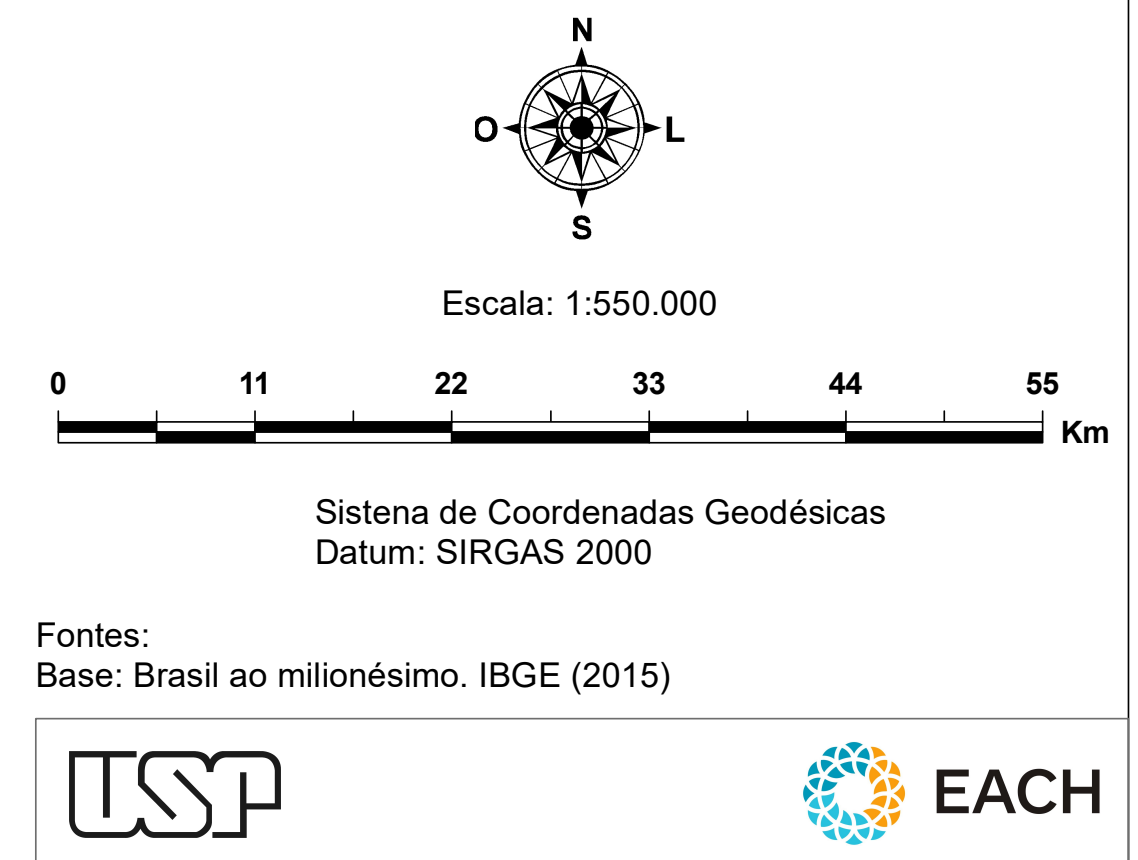

Regeneração florestal após o desmatamento: estudo da região de Santarém, Pará, Brasi

Diego Pinheiro de Menezes

Mapa 5 Estágios de Sucessão Florestal em 1995 Dissertação de mestrado 


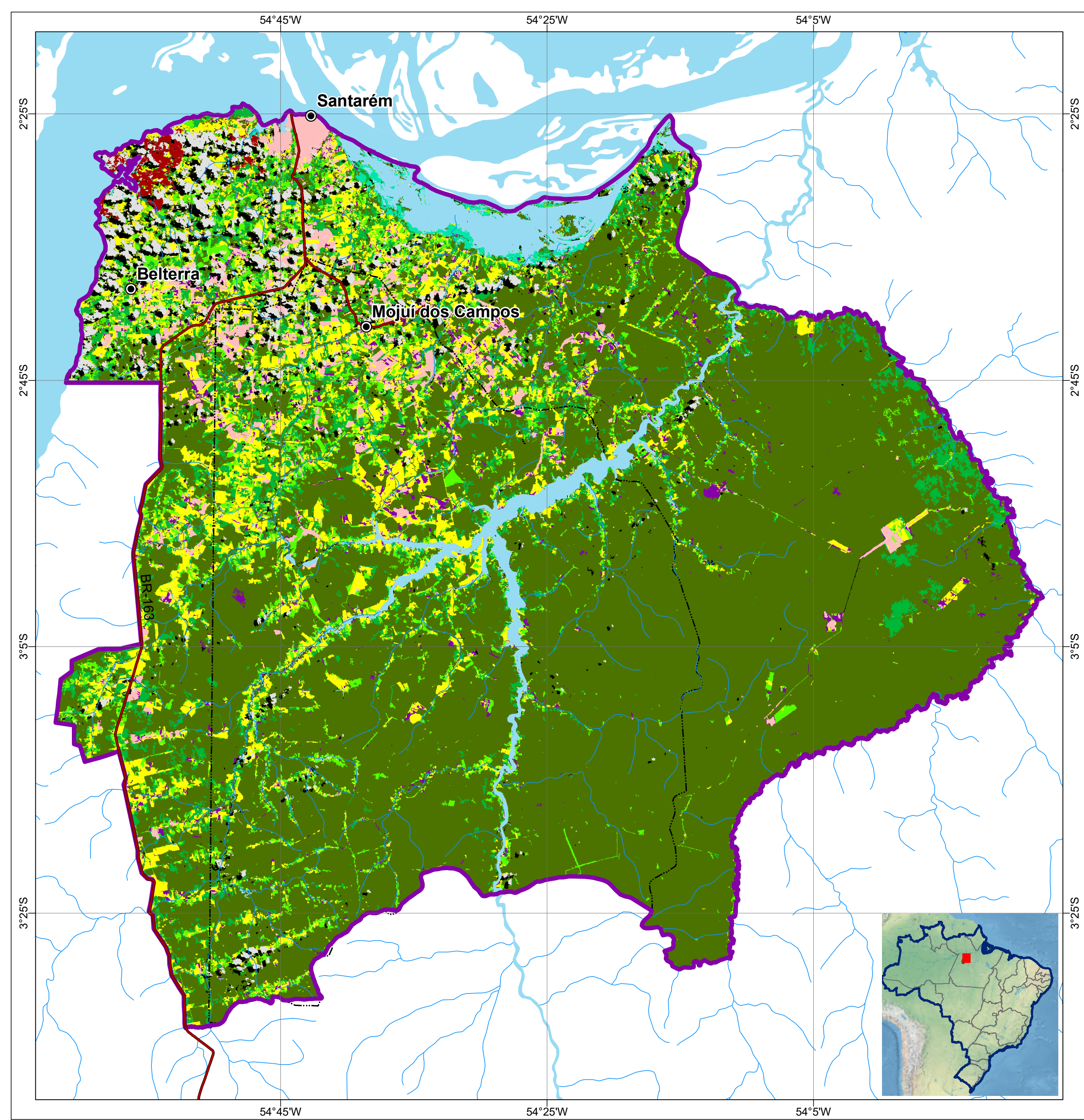

- Sedes municipais

Estradas principais

Curso d'agua

3 Massas d'água

Limties municipais

03 Área de estudo

Uso e cobertura da terra

Efeitos atmosféricos

Nuvem

Sombra

Uso da terra

Solo exposto

Pastagem e campos

Degradação florestal recente

Cobertura vegetal

Cerrado-Campo

Área alagada

Floresta 5 a 15 anos (SS1)

Floresta 15 a 30 anos (SS2)

Floresta $>30$ anos (SS3)

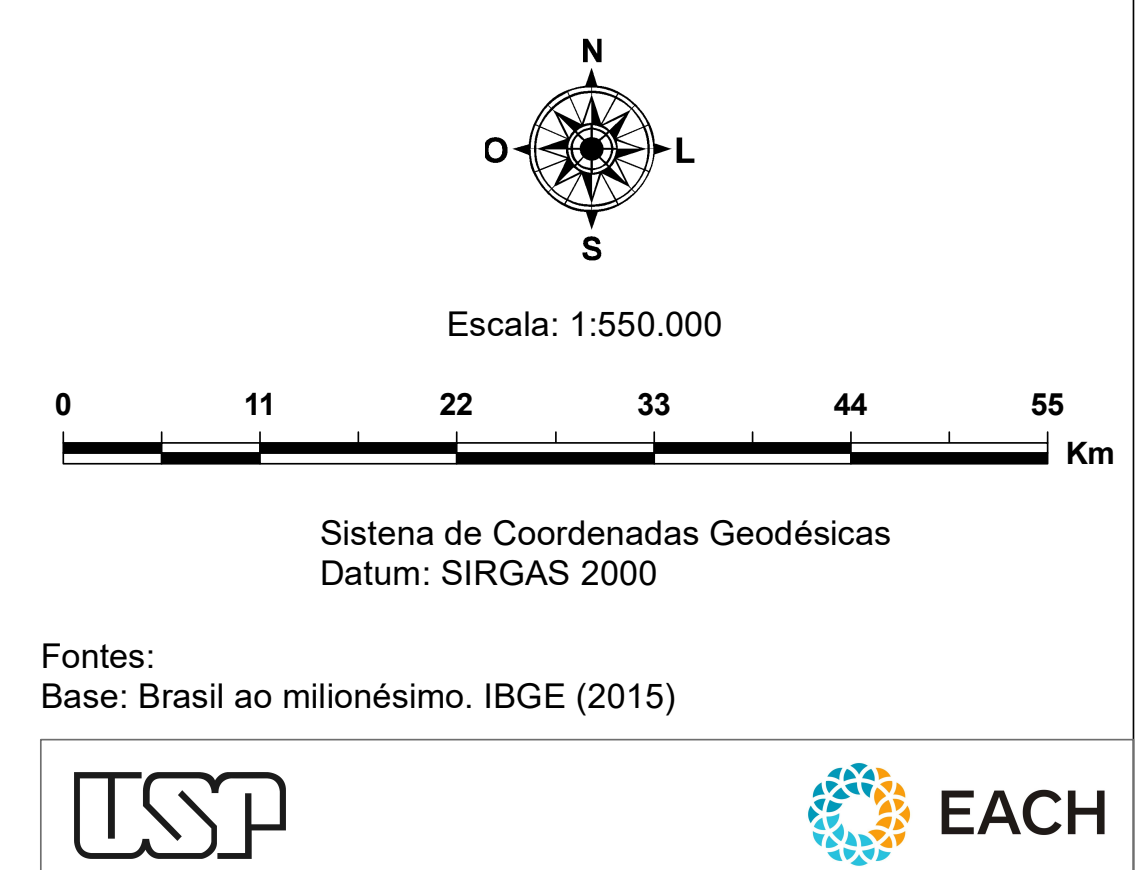

Regeneração florestal após o desmatamento: estudo da região de Santarém, Pará, Brasi

Diego Pinheiro de Menezes

Mapa 6 Estágios de Sucessão Florestal em 2006 Dissertação de mestrado 


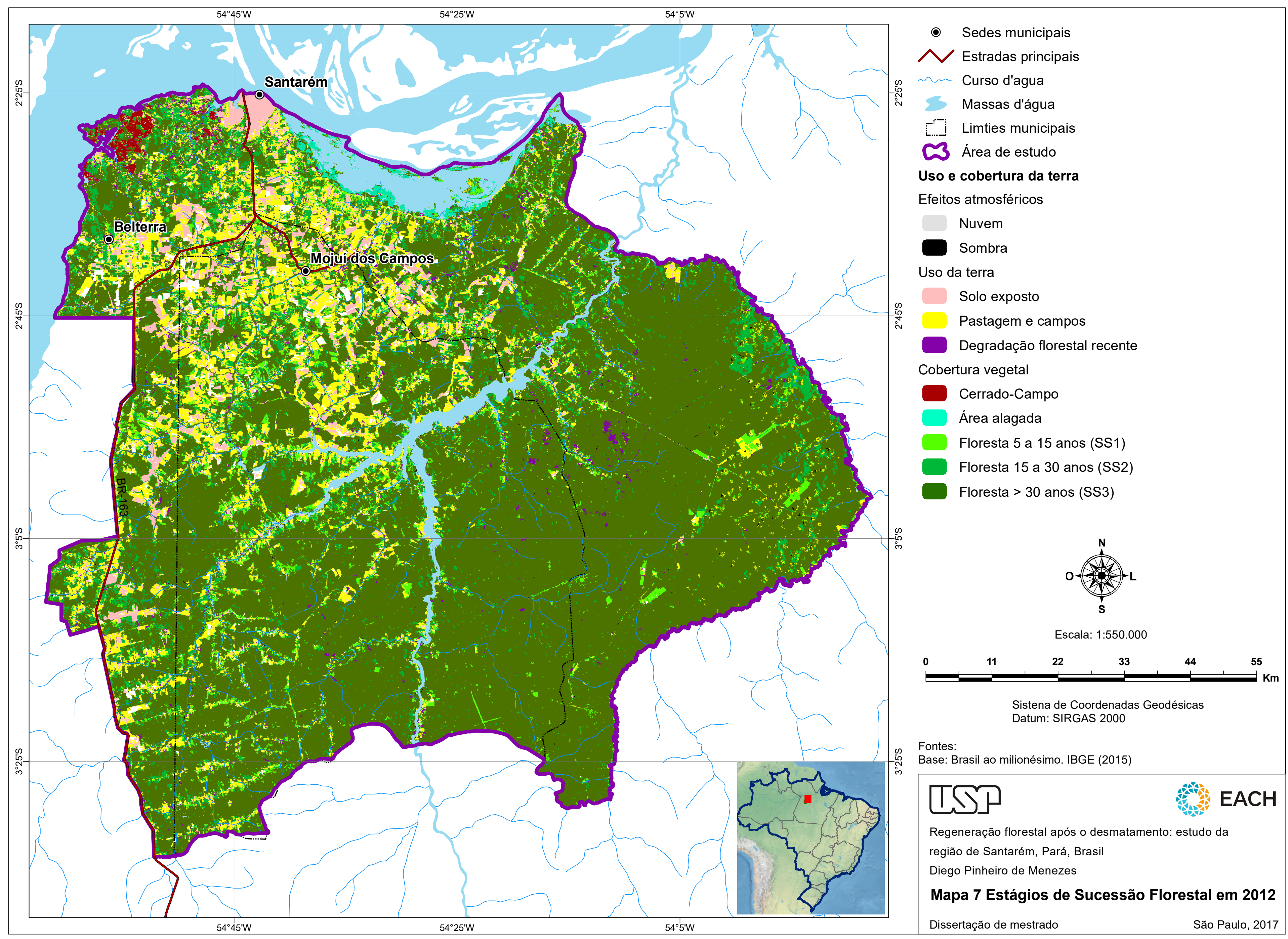




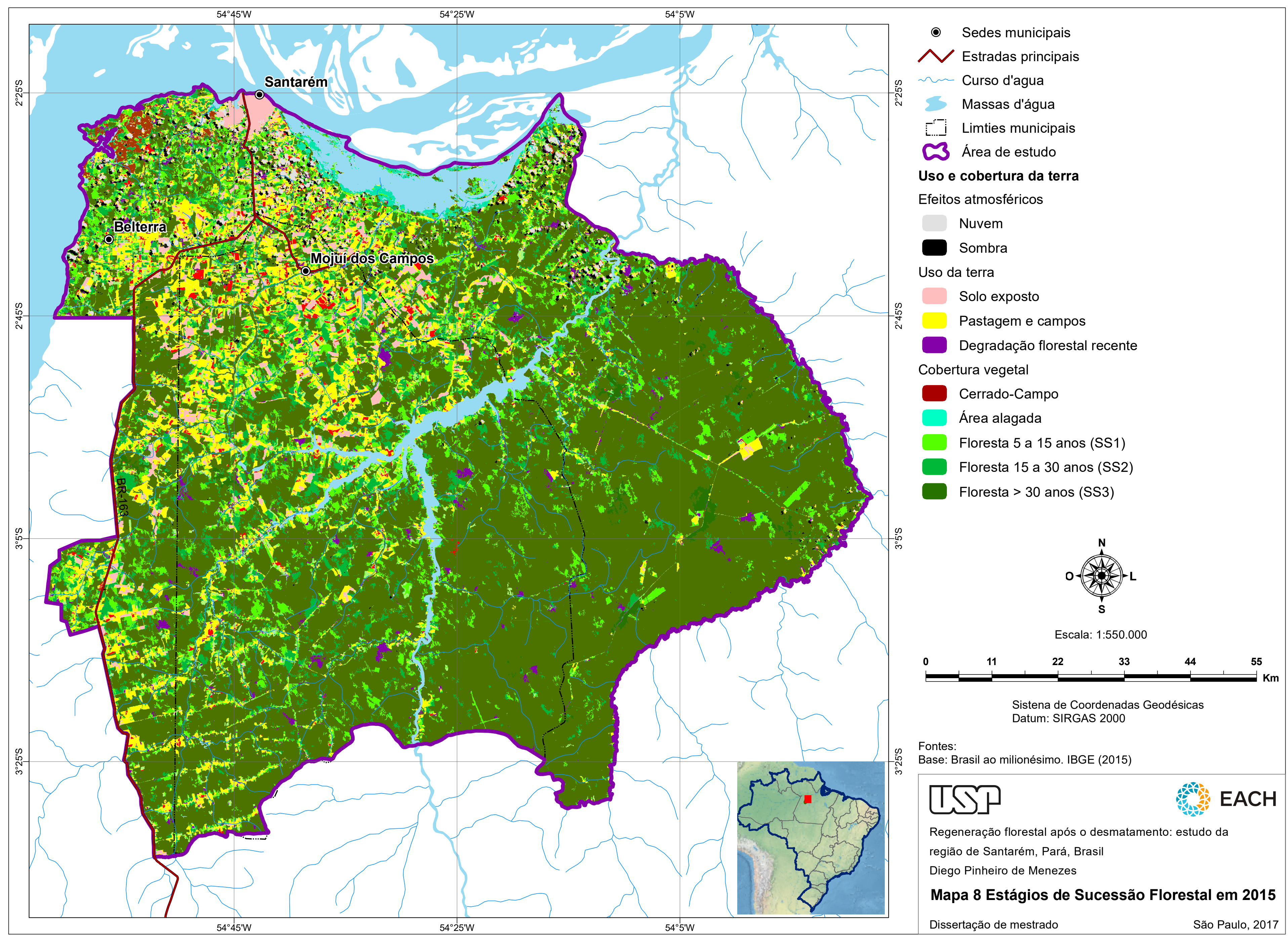




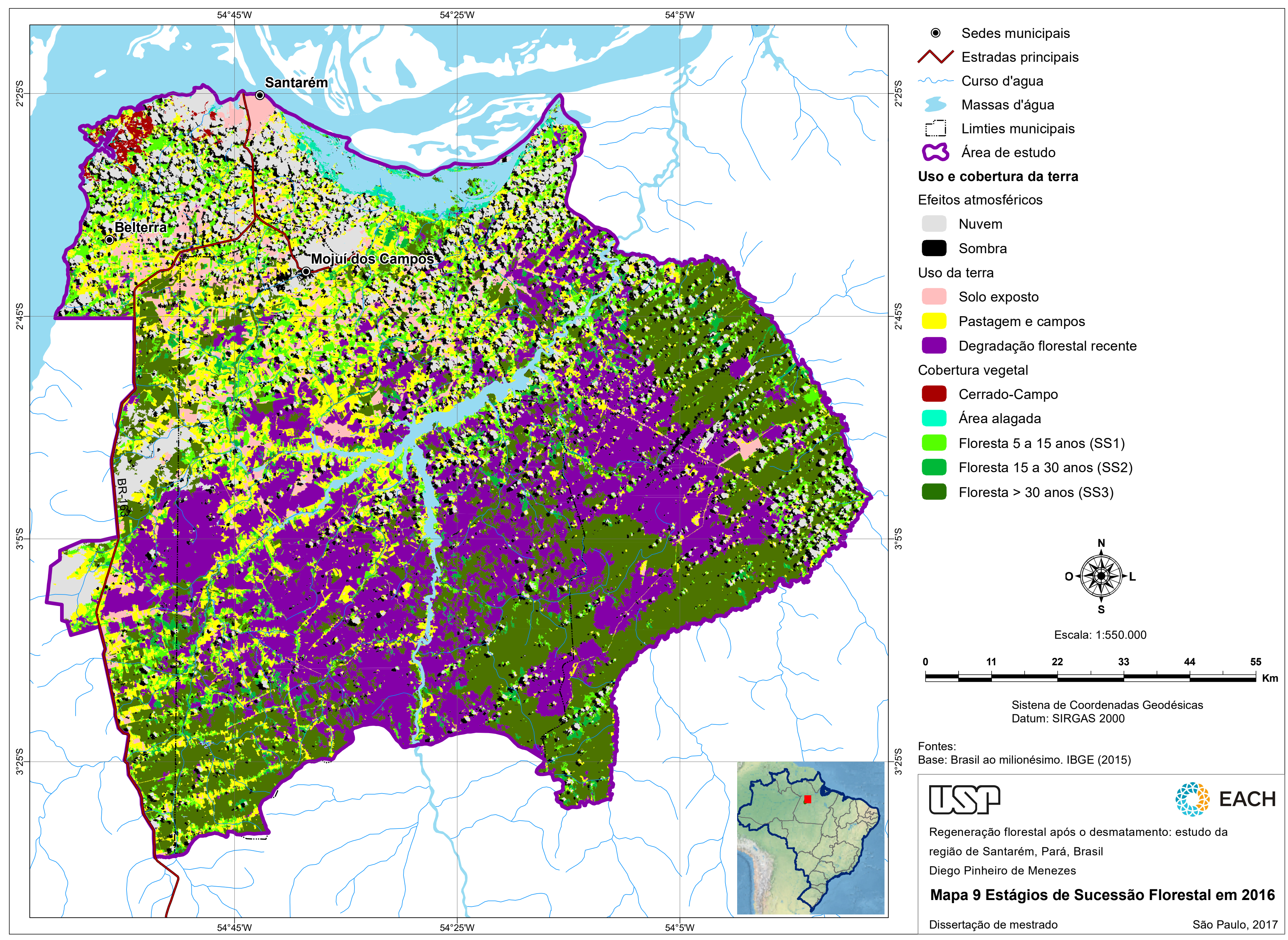




\section{CONCLUSÃO}

São as relações econômicas e políticas dos homens que transformam a terra em terra de pasto e plantio; a mata em reserva de índios, drogas do sertão, látex, castanha, lenha, madeira, peles; o rio em reserva de peixes e caminho; a sombra em repouso; os espaços em lugares: sem fim, sertão, floresta, cerrado, seringal, sítio, latifúndio, posse, fazenda, arraial

(IANNI, 1978, p. 230).

O artigo 170 da Constituição (BRASIL,1988) observa os princípios norteadores da ordem econômica, dentre eles a soberania nacional, o reconhecimento da propriedade privada e a função social dela, e a defesa do meio ambiente mediante o tratamento diferenciado conforme o impacto ambiental gerado por produtos $\mathrm{e}$ serviços, e a redução da desigualdade social. Ao determinar estes princípios, o Brasil afirma qual o caminho para o desenvolvimento econômico deseja seguir.

São princípios que convergem ao conceito de desenvolvimento sustentável do Relatório Brundtland (UNITED NATIONS, 1987), definido como um processo de mudança que busca atender as necessidades [essenciais] do presente sem comprometer a capacidade das gerações futuras em satisfazer suas necessidades. Era a chamada pela tomada ações a favor da redução da desigualdade social e pela defesa do meio ambiente a nível global.

O desenvolvimento econômico tende $\mathrm{a}$, invariavelmente, criar ou reforçar prosperidade à custa da degradação ambiental e social, mas é necessário reconhecer avanços significativos nos últimos 30 anos. A redução efetiva do desmatamento na Amazônia graças ao esforço combinado entre o Estado e a sociedade civil, além da implementação de outras políticas reparadoras como o combate ao trabalho escravo, reforçam esta tese. A valorização de atividades econômicas alternativas às atividades ilegais (como o roubo de madeira e o garimpo) pode ajudar a reduzir o desmatamento a taxas menores que a menor taxa já registrada, em 2012, com $4.571 \mathrm{~km}^{2}$.

No entanto, a percepção de anistia e impunidade para a prática de crimes ambientais fomentada pela aprovação do Novo Código Florestal em 2012, pelo abrandamento das ações de fiscalização e pela alteração nos limites de unidades de conservação ao redor da BR-163 resultaram na interrupção da queda das taxas de 
desmatamento e variações positivas taxas desde 2013. Os dados consolidados de desmatamento para 2015 e as estimativas para 2016 do PRODES (INPE, 2016) mostraram uma variação de $29 \%$ entre 2015 e 2016, de $6.207 \mathrm{~km}^{2}$ para $7.989 \mathrm{~km}^{2}$ respectivamente. Ou seja, os dados preliminares de desmatamento para 2016 mostram o retorno à taxa de desmatamento próxima daquela registrada em 2009, quando $7.464 \mathrm{~km}^{2}$ de floresta foram perdidos na Amazônia brasileira.

Um dos objetivos específicos deste estudo era compreender os antecedentes históricos que levaram às mudanças no uso da terra e na formação de floresta secundária nana região de Santarém. Estas mudanças podem ser resumidas em três ciclos de devassidão da Amazônia de acordo com Becker (1990): o colonial, a economia da borracha e o moderno, iniciado há mais de 40 anos em que a Amazônia passa a ser grande região de expansão do capital no Brasil. Santarém é uma das regiões sob influência intensa deste processo desde o final da década de 1990, como trabalhado no Capítulo 3.

A meta de aumentar a cobertura florestal nos trópicos segundo Chazdon (2014), através da regeneração florestal passiva ou do reflorestamento, baseia-se no reconhecimento que as florestas precisam das pessoas, assim como as pessoas precisam de florestas. A disponibilidade de recursos e espécies (a memória ecológica) são fatores ecológicos condicionantes à regeneração florestal, mas o principal fator condicionante é econômico, seja pela disponibilidade de terras ou recursos financeiros destinados à regeneração.

Em 23 de janeiro de 2017 a Presidência da República publicou o Decreto 8.972 (BRASIL, 2017), que institui a Política Nacional de Recuperação da Vegetação Nativa (PROVEG), tendo como objetivo articular, integrar e promover políticas, programas e ações indutoras da recuperação de florestas e demais formas de vegetação nativa, e impulsionar a regularização ambiental de propriedade de acordo com o Novo Código Florestal (BRASIL, Lei 12.727, 2012).

O PROVEG reconhece e define no Artigo $3^{\circ}$ - IV, os processos de regeneração natural conduzida e passiva, reabilitação ecológica, restauração ecológica, reflorestamento e recuperação da vegetação nativa, e define as diretrizes desta política como o CAR e o incentivo à conservação e recuperação da vegetação nativa e institui a Comissão Nacional para Recuperação da Vegetação Nativa (CONAVEG), que será formada por membros de ministérios, governos estaduais e representantes da sociedade civil envolvidos com a recuperação da vegetação nativa. 
O PROVEG é um grande avanço ao reconhecer legalmente a regeneração florestal, as variadas formas de condução ou estímulo, e definir diretrizes para a sua realização. Ele não estabelece normas para limpeza e supressão tal como as instruções normativas $n^{\circ} 02$ (SEMAS-PA, 2014) e nº 05 (SEMAS-PA, 2015), mas é um avanço significativo rumo à recuperação de áreas degradadas e para a recomposição de florestas.

A produção de informação geográfica de referência pode contribuir a este processo de recuperação, com dados que permitam distinguir áreas com histórico de intenso antropismo e, portanto, desprovida de memória ecológica, além de outras áreas com menor perturbação e capacidade de regeneração florestal pouco modificada. Conforme afirmado anteriormente, a estratégia de restauração de uma determinada área deve ser precedida pelo histórico do uso da terra pois isso influenciará o modelo biológico de restauro e poderá evitar esforços redobrados (RIBEIRO; BRUNA; MANTOVANI, 2010).

Este estudo procurou desenvolver uma nova abordagem para identificar e analisar mudanças na extensão de floresta secundária como resultado do desmatamento e de processos de degradação florestal, com base no sensoriamento remoto e na Análise Orientada a Objetos Geográficos (GEOBIA). Alguns estudos de referência foram consultados, mas dificuldades foram encontradas em definir valores limiares uniformes a distinção entre os intervalos, de modo a contar com uma única árvore de decisão para ser aplicada em, pelo menos, um mesmo sensor.

Com isso espera-se contribuir ao desenvolvimento de uma abordagem para o mapeamento dos estágios de sucessão secundaria em função do histórico do uso da terra de uma região da Amazônia Central e, também, do referencial jurídico disponível sobre conservação e abaste de cobertura vegetal com base no estágio sucessão. Para isso foram de grande importância os trabalhos de Blaschke (2010), de Sato et al. (2013), de Carreiras et al. (2014), e Piazza et al. (2016), de onde se adaptou uma abordagem baseada em GEOBIA, em mineração de dados (para construção de uma árvore de decisão) e em geoprocessamento para se atingir este objetivo.

Dentre as razões para o desenvolvimento desta abordagem estavam a falta de dados detalhados sobre a ocorrência e extensão de floresta secundária até recentemente, até o início da publicação dos dados TERRACLASS (INPE-CRA, 2016). Estes dados são de grande importância ao reconhecimento da cobertura atual, 
mas a série temporal curta (2004 a 2014) impede análises históricas e a evolução dos estágios de sucessão durante determinado período.

O mapeamento de estágios de sucessão secundária tem limitações relacionadas à similaridade da irradiância de diferentes tipos de cobertura vegetal, que destacam o brilho mas impedem interpretações mais avançadas sobre estrutura de dossel. Ao empregar o modelo de mistura espectral, Lucas et al. (1993) apontou a impossibilidade de identificar estágios de sucessão com esta abordagem e com as imagens LANDSAT. Ao realizar o mapeamento da cobertura vegetal da FLONA Tapajós, Espírito Santo (2003) teve de agrupar as classes de sucessão secundária para contabilização dos resultados, mas também devido aos limiares entre as duas classes de sucessão secundária. Carreiras et al. (2014) teve de criar uma máscara da classe floresta para melhor contabilização das classes de cobertura vegetal e obteve os dados de sucessão secundária com base na análise comparativa das classificações geradas para cada período analisado.

Neste estudo a aplicação de GEOBIA em imagens multiespectrais (LANDSAT e IRS-P6) obteve bons resultados com a segmentação. Através da experiência empírica obteve-se parâmetros que permitiram reconhecer os objetos correspondentes à floresta secundária. A exploração de 14 atributos ofereceu uma boa possibilidade exploratória, mas que se demonstrou limitada pela resolução espacial das imagens utilizadas. Particularmente em relação aos atributos de textura (GLCM) a resolução espacial média pode ser a principal razão da baixa performance deste atributo.

Em contraste, os índices de vegetação SAVI e NDMI foram os atributos mais recorrentes na formação de nós da árvore de decisão. Os valores de correlação destes atributos também foram satisfatórios, próximos a 1 para as três classes de floresta definidas na classificação. O desenvolvimento de uma abordagem ou técnica que melhor contemplasse a estrutura de dossel pode trazer melhores resultados para construção de uma árvore de decisão.

Ao explorar os resultados da primeira classificação no aplicativo de mineração de dados, os índices de vegetação preponderam sobre os demais atributos espectrais e de textura para constituição da árvore de decisão da classificação final. Para uma classificação ter valores limiares equivalente ou próximos em diferentes imagens é necessário realizar o cálculo radiométrico ou o uso de imagens já corrigidas como as processadas no LEDAPS (USGS, 2016) Segundo Chander, Markham e Barsi (2007), 
a normalização radiométrica é um passo fundamental para alocar dados de diferentes sensores e plataformas para uma escala radiométrica comum. Com exceção apenas a imagem de 2012, fornecida pelo satélite IRS-P6, todas as outras cenas (LANDSAT 5, LANDSAT 7 e LANDSAT8) usadas neste estudo tiveram normalização realizada via LEDADPS (USGS, 2016).

Os testes realizados para determinação o algoritmo mais apropriado para criação das árvores de decisão no WEKA. A análise de seis diferentes classificadores corrobora as conclusões de Sato et al. (2013), que analisaram estes mesmos seis e outros seis classificadores não analisados neste estudo. Os resultados levam a uma avaliação positiva do SIMPLECART (BREIMAN et al., 1984) e do J48 (QUINLAN, 1993). Os testes também permitiram verificar a importância da quantidade, mas também da veracidade dos dados de entrada. Neste estudo, ao invés de usar a massa completa de dados de uma classificação como dado de entrada no WEKA, optou-sepor utilizar somente os segmentos amostrados, ou seja, os segmentos que serviram como amostra de treinamento da primeira classificação foram utilizados como dados de entrada na mineração de dados para, enfim, criar a árvore de decisão de cada período e a segunda classificação baseada apenas nos valores limiares encontrados para cada classe em cada período classificado.

Segundos os valores de acurácia e da Matriz de Confusão, as classes com os melhores resultados de classificação foram aquelas com pouca ou nenhuma cobertura vegetal como nuvens, solo exposto, massa d'água, sombra, além de pastagens e campos, com acerto superior a 90\%, seguido por floresta madura e degradação florestal recente, com valores também próximos a $90 \%$. Os resultados com a classe degradação florestal recente foram animadores pois sua classificação dispensou o trabalho de pós-classificação e pode se relevar uma alternativa ao mapeamento de degradação florestal originada pela prática fogo ou corte seletivo ilegal.

Cabe ressaltar que, neste estudo, compreendeu-se degradação florestal recente as cicatrizes de queimada e clareiras abertas para extração ilegal de madeira praticadas em até um ano antes da data da coleta da imagem orbital. Nesta abordagem não foi contemplada a degradação florestal antiga, sem data definida, pois a resposta espectral e de textura é semelhante ao da sucessão secundária. Uma vez abandonada a clareira ou a cicatriz de queimada, a sucessão secundária tende a se desenvolver caso a memória ecológica não esteja comprometida. 
Cabe notar que onde foi identificada a degradação florestal necessita atenção e monitoramento pois ela pode ser alvo de novas ações de roubo de madeira ou de corte raso. Portanto, os 286.459 hectares de degradação florestal recente identificados na área de estudo necessitam de um acompanhamento dado o histórico recente de expansão de ocupação de terras a partir de Santarém em direção ao eixo da rodovia transamazônica (BR-230) e ao longo da rodovia transuruará (PA-370).

Os menores acertos foram registrados nas classes área alagada, sucessão secundária 1 (5 a 15 anos) e sucessão secundária 2 (15 a 30 anos). Uma possível solução pode ser a supressão da classe área alagada pois ela possui resposta na faixa do espectro similar as outras duas classes. Outra solução possível pode ser a aplicação de uma única classe para floresta secundária e o refinamento dela com pós-processamento.

Os resultados da árvore de classificação sugerem que a abordagem precisa ser melhorada, eliminando classes que diminuem a acurácia da classificação e incorporando atributos que melhor representem a estrutura da vegetação, com algum outro índice de vegetação e dados de elevação digital do terreno.

Em relação à classe floresta madura, os resultados revelaram uma significativa redução em 32 anos: de 863 mil hectares em 1984 para 306 mil hectares em 2016, uma perda de $64 \%$ da cobertura florestal em 32 anos sem considerar as classes de sucessão secundária e degradação florestal recente. $O$ mesmo não ocorre com a classe floresta secundária, pois a alta rotatividade envolvendo a abertura de novas clareiras em floresta madura e a limpeza de áreas em regeneração resultaram em ciclos curtos de regeneração (pousio). Em 2016 haviam 78 mil hectares com até 5 anos de regeneração, 5,5 mil hectares com até 15 anos de regeneração, e 602 hectares remanescentes de 1986 (30 anos antes). Nos anos anteriores o padrão se repete, a maior parte das áreas em regeneração não possui mais que 5 anos.

Os resultados da classificação sugerem que a regulamentação jurídica para o licenciamento do desmatamento de floresta secundária terá pouco efeito prático na conservação pois a prática do desmate da cobertura vegetal com até 5 anos de regeneração é uma prática recorrente em todos os períodos analisados, de 1984 até 2016, e o incremento na redução da cobertura florestal evidenciada pela mancha de 250 mil hectares de degradação florestal recente, pelo fogo, em 2016 pode ter sido efeito de uma estiagem ou da maior pressão para exploração ou derrubada da cobertura florestal remanescente. 


\section{REFERÊNCIAS}

ADAMS, J.; Classification of multispectral images based on fractions of endmembers: Application to land-cover change in the Brazilian Amazon. Remote Sensing of Environment. v. 52, p. 137-154, 1995.

ALMEIDA, C. A.; VALERIANO, D. M.; ESCADA, M. I. S.; RENNÓ, C. D Estimativa de área de vegetação secundária na Amazônia Legal Brasileira. Acta Amazonica, v. 40, n. 2, p. 289-301, 2010.

AMARAL, S.; COSTA, C.B.; ARASATO, L.S.; XIMENES, A.C.; RENNÓ, C.D. AMBDATA: Variáveis ambientais para Modelos de Distribuição de Espécies (SDMs). In: SIMPÓSIO BRASILEIRO DE SENSORIAMENTO REMOTO, 16. (SBSR), 2013, Foz do Iguaçu. Anais. São José dos Campos: Instituto Nacional de Pesquisas Espaciais, 2013. Dados disponíveis em http://www.dpi.inpe.br/Ambdata/index.php . Acesso em 31 jan 2017.

APLIN, P.; SMITH, G. M. Introduction to object-based landscape analysis. International Journal of Geographical Information Science, v. 25, n. 6, p. 869-875, 2011.

ARIMA, E. Y.; WALKER, R. T.; PERZ, S.; SOUZA, C. Explaining the fragmentation in the Brazilian Amazonian forest. Journal of Land Use Science, n. July, p. 1-21, 272015

ARROYO-KALIN, M. The Amazonian formative: Crop domestication and anthropogenic soils. Diversity, v. 2, n. 4, p. 473-504, 2010.

BACEN - BANCO DENTRAL DO BRASIL. Anuário estatístico do crédito rural (até 2012). Brasília: BACEN, 2012. Disponível em: https://www.bcb.gov.br/?RELRURAL Acesso em 31 jan. 2017.

BACEN - BANCO DENTRAL DO BRASIL. Resolução $n^{\circ} 4.487$, de 31 de maio de 2016. Ajusta dispositivos da Seção 1 (Disposições Gerais) do Capítulo 2 (Condições Básicas) do Manual de Crédito Rural (MCR).

BACEN - BANCO DENTRAL DO BRASIL. Resolução n 3.545 , de 29 de fevereiro de 2008. Altera o Manual de Credito Rural (MCR) para estabelecer exigência de documentação comprobatória de regularidade ambiental e outras condicionantes, para fins de financiamento agropecuário no Bioma Amazônia.

BANDEIRA. M. Estrela da Tarde. Rio de Janeiro: José Olympio, 1982.

BARLOW, J.; PERES, C. A. Ecological responses to El Nino-induced surface fires in central Brazilian Amazonia: management implications for flammable tropical forests. Philosophical Transactions of the Royal Society B: Biological Sciences, v. 359, n. 1443, p. 367-380, 2004

BATISTELLA, M.; MORAN, E.M. Dimensões humanas do uso e cobertura das terras na Amazônia: uma contribuição do LBA. Acta Amazonica, v.35 (2), p.239-247, 2005.

BECKER, B. K.Geopolítica da Amzônia. Estudos Avançados, v. 19, no 53, 2005

BECKER, B. K. Amazônia. São Paulo: Ática, 112 p. 1990

BENGTSSON, J.; ANGELSTAM, P.; ELMQVIST, T.; EMANUELSSON, U.; FOLKE, C.; IHSE, M.; MOBERG, F.; NYSTRÖM, M Reserves, resilience and dynamic landscapes. AMBIO, 32, p.389-396, 2003 
BERK, A; BERNSTEIN, L. S.;ROBTERSON, D. C. MODTRAN: A moderate resolution model for LOWTRAN 7. Air Force Geophysics Lab. Tech. Rep. GL-TR-89-0122, Hanscom AFB, MA, 1989

BEOZZO, J. O. Leis e regimentos das Missões - Política Indígenista no Brasil. São Paulo, Edições Loyola, 1984.

BLASCHKE, T. Object based image analysis for remote sensing. ISPRS Journal of Photogrammetry and Remote Sensing, v. 65, n. 1, p. 2-16, 2010.

BLASCHKE, T.; HAY, G. J.; KELLY, M.; LANG, S.; HOFMANN, P.; ADDINK, E.; QUEIROZ FEITOSA, R.; VAN DER MEER, F.; VAN DER WERFF, H.; VAN COILLIE, F.; TIEDE, D. Geographic Object-Based Image Analysis - Towards a new paradigm. ISPRS Journal of Photogrammetry and Remote Sensing, v. 87, p. 180-191, 2014.

BLASCHKE, T.; STROBL, J. What's wrong with pixels? Some recent developments interfacing remote sensing and GIS. Interfacing Remote Sensing and GIS, n. October, p. 1-7, 2001.

BOYD, D. S.; DANSON, M. Satellite remote sensing of forest resources: three decades of research development. v. 1, p. 1-26, 2005.

BRASIL. Instrução Normativa do Ministério do Meio Ambiente №2, de 05 de maio de 2014 - D.O.U.: 06 de maio de 2014. Dispõe sobre os procedimentos para a integração, execução e compatibilização do Sistema de Cadastro Ambiental Rural - SICAR e define os procedimentos gerais do Cadastro Ambiental Rural - CAR.

BRASIL. Decreto 7.930, de 17 de outubro de 2012. Dispõe sobre o Sistema de cadastro Ambiental Rural, o Cadastro Ambiental Rural, estabelece normas de caráter geral aos Programas de Regularização Ambiental, de que trata a Lei no 12.651, de 25 de maio de 2012, e dá outras providências.

BRASIL. Lei Federal 12.727, de 17 de outubro de 2012. Altera a Lei no 12.651, de 25 de maio de 2012, que dispõe sobre a proteção da vegetação nativa; altera as Leis nos 6.938, de 31 de agosto de 1981, 9.393, de 19 de dezembro de 1996, e 11.428, de 22 de dezembro de 2006; e revoga as Leis nos 4.771, de 15 de setembro de 1965, e 7.754, de 14 de abril de 1989, a Medida Provisória no 2.166-67, de 24 de agosto de 2001, o item 22 do inciso II do art. 167 da Lei no 6.015, de 31 de dezembro de 1973, e o § 20 do art. 40 da Lei no 12.651, de 25 de maio de 2012.

BRASIL. Lei Federal 12.651, de 25 de maio de 2012. Dispõe sobre a proteção da vegetação nativa, altera as leis $6.938,9.393,11.428,4.771,7.554$, medida provisória 2.166-67 e dá outras providências.

BRASIL. Lei Federal 9.605, de 12 de fevereiro de 1998. Dispõe sobre as sanções penais e administrativas derivadas de condutas e atividades lesivas ao meio ambiente, e dá outras providências.

BRASIL. Constituição da República Federativa do Brasil de 1988

BRASIL. Lei Federal 4.771, de 15 de setembro de 1965. Institui o Código Florestal.

BREIMAN, L.; FRIEDMAN, J.H.; OLSHEN, R.A.; STONE, C.J. Classification and regression trees. Belmont, California: Wadsworth International Group, 358 p. 1984.

BROWN, S.; LUGO, A. E. Tropical secondary forests. Journal of Tropical Ecology, v. 6, n. 01, p. 1, 1990. 
CARDOSO, F.H.; MULLER, G. Amazônia: expansão do capitalismo. São Paulo: Brasiliense, 208 p., 1978.

CARREIRAS, J. M. B.; JONES, J.; LUCAS, R. M.; GABRIEL, C. Land use and land cover change dynamics across the Brazilian Amazon: Insights from extensive timeseries analysis of remote sensing data. PLoS ONE, v. 9, n. 8, 2014.

CASTILLA, G.; HAY, G.J. Image objects and geographic objects. In T. Blaschke, S. Lang, \& G. J. Hay. (org.). Object-Based Image Analysis: Spatial Concepts for Knowledge-Driven Remote Sensing Applications. Berlin, Heidelberg: Springer Berlin Heidelberg, p. 91-110, 2008.

CASTILLO-NÚÑEZ, M. SÁNCHEZ-AZOFEIFA, G. A.; CROITORU, A.; RIVARD, B.; CALVO-ALVARADO, J.; DUBAYAH, R. O Delineation of secondary succession mechanisms for tropical dry forests using LiDAR. Remote Sensing of Environment, v. 115, n. 9, p. 2217-2231, 2011.

CHANDER, G.; MARKHAM, B. L.; BARSI, J. A. Revised landsat-5 thematic mapper radiometric calibration. IEEE Geoscience and Remote Sensing Letters, v. 4, n. 3, p. 490-494, 2007.

CHAVEZ JR, P. T. An improved dark-object subtration technique for atmospheric scattering correction of multispectral data. Remote Sensing of Environment, v.24, p. $459-479,1988$

CHAZDON, R. L. BROADBENT, E. N.; ROZENDAAL, D. M. A.; BONGERS, F.; ZAMBRANO, A. M. A.; AIDE, T. M.; BALVANERA, P.; BECKNELL, J. M.; BOUKILI, V.; BRANCALION, P. H. S.; CRAVEN, D.; ALMEIDA-CORTEZ, J. S.; CABRAL, G. A. L.; DE JONG, B.; DENSLOW, J. S.; DENT, D. H.; DEWALT, S. J.; DUPUY, J. M.; DURÁN, S. M.; ESPÍRITO-SANTO, M. M.; FANDINO, M. C.; CÉSAR, R. G.; HALL, J. S.; HERNÁNDEZ-STEFANONI, J. L.; JAKOVAC, C. C.; JUNQUEIRA, A. B.; KENNARD, D.; LETCHER, S. G.; LOHBECK, M.; MARTÍNEZ-RAMOS, M.; MASSOCA, P.; MEAVE, J. A.; MESQUITA, R.; MORA, F.; MUÑOZ, R.; MUSCARELLA, R.; NUNES, Y. R. F.; OCHOA-GAONA, S.; ORIHUELA-BELMONTE, E.; PEÑA-ClAROS, M.; PÉREZ-GARCÍA, E. A.; PIOTTO, D.; POWERS, J. S.; RODRÍGUEZ-VELAZQUEZ, J.; ROMERO-PÉREZ, I. E.; RUÍZ, J.; SALDARRIAGA, J. G.; SANCHEZ-AZOFEIFA, A.; SCHWARTZ, N. B.; STEININGER, M. K.; SWENSON, N. G.; URIARTE, M.; VAN BREUGEL, M.; VAN DER WAL, H.; VELOSO, M. D. M.; VESTER, H.; VIEIRA, I. C. G.; BENTOS, T. V.; WILLIAMSON, G. B.; POORTER, L. Carbon sequestration potential of second-growth forest regeneration in the Latin American tropics. Science Advances, v. 2, n. 5, 2016.

CHAZDON, R. L. Second Growth: the promise of tropical forest regeneration in an age of deforestation. Chicago: The University of Chicago Press, 449 p., 2014

CHAZDON, R. L. Regeneração de florestas tropicais Tropical forest regeneration. Boletim do Museu Paraense Emílio Goeldi. Ciências. Naturais, Belém, v. 7, n. 3, p. 195-218, 2012.

CHAZDON, R. L. Beyond deforestation: Restoring forests and ecosystem services on degraded lands. Science, v. 320, n. 5882, p. 1458-1460, 2008.

CHAZDON, R. L. Tropical forest recovery: legacies of human impact and natural disturbances. Perspectives in Plant Ecology, Evolution and Systematics, v. 6, n. 1-2, p. 51-71, 2003. 
CHAZDON, R.L.; ARROYO, J.P. Tropical forests as complex adaptive systems. In: MESSIER, $C$ et al. (org) Managing world forests as complex adaptive systems in the face of global change. Nova York: Routeledge, p.35-59, 2013.

CHEN, Y.; SU, W.; LI, J.; SUN, Z. Hierarchical object oriented classification using very high resolution imagery and LIDAR data over urban areas. Advances in Space Research, v. 43, n. 7, p. 1101-1110, 2009.

CHOKALINGAM, U. Secondary forest: a working definition and topology. International Forestry Review, v. 3, n. 1, p. 19-27, 2001.

CLEARY, D. "Lost Altogether to the Civilised World": Race and the Cabanagem in Northern Brazil, 1750 to 1850 . Comparative Studies in Society and History, v. 40, n. 01, p. 109-135, 1998.

CLEARY, D. After the Frontier: Problems with Political Economy in the Modern Brazilian Amazon. Journal of Latin American Studies, v. 25, n. 02, p. 331, 1993.

CONCEIÇÃO PRATES-CLARK, C. DA; LUCAS, R. M.; SANTOS, J. R. DOS. Implications of land-use history for forest regeneration in the Brazilian Amazon. Canadian Journal of Remote Sensing, v. 35, n. 6, p. 534-553, 2009.

CORDEIRO, C. L. D. O.; ROSSETTI, D. D. F. Mapping vegetation in a late Quaternary landform of the Amazonian wetlands using object-based image analysis and decision tree classification. International Journal of Remote Sensing, v. 36, n. 13, p. 3397-3422, 2015.

CORLETT, R. What is Secondary Forest? Journal of Tropical Ecology, v. 10, n. 3, p. 445-447, 1994.

DESCLÉE, B.; BOGAERT, P.; DEFOURNY, P. Forest change detection by statistical object-based method. Remote Sensing of Environment, v. 102, n. 1-2, p. 1-11, 2006.

DRONOVA, I.; GONG, P.; WANG, L.; ZHONG, L. Mapping dynamic cover types in a large seasonally flooded wetland using extended principal component analysis and object-based classification. Remote Sensing of Environment, v. 158, p. 193-206, 2015.

DUFOUR, D. L. Cyanide content of cassava (Manihot esculenta, Euphorbiaceae) cultivars used by Tukanoan Indians in Northwest Amazonia. Economic Botany, v. 42, n. 2, p. 255-266, 1988.

ESPÍRITO-SANTO, F. D. B. Caracterização e mapeamento da vegetação da região da Floresta Nacional do Tapajós através de dados óticos, radar e inventários florestais. Dissertação. Instituto Naciona de Pesquisas Espaciais. 277 p., 2003.

ESRI - Environemtnal Systems Research Institute. ARCGIS 10.4 Help Library. 2015.

EXILIS. ENVI version 5.0 Manual. Boulder, Colorado, 2014.

FAO. Global Forest Resources Assessment. America, v. 147, 350 p., 2010.

FEARNSIDE, P. M. Deforestation in Brazilian Amazonia: History, rates, and consequences. Conservation Biology, v. 19, n. 3, p. 680-688, 2005

FEARNSIDE P. M. Amazonian deforestation and global warming: Carbon stocks in vegetation replacing Brazil's Amazon forest. Forest Ecology and Management, v. 80: p. 21-34. 1996 
FELDPAUSCH, T. R.; PRATES-CLARK, C. da C.; FERNANDES, E. C. M.; RIHA, S. J. Secondary forest growth deviation from chronosequence predictions in central Amazonia. Global Change Biology, v. 13, n. 5, p. 967-979, 2007.

FINEGAN, B. Pattern and process in neotropical secondary rain forests: the first 100 years of succession. Trends in Ecology \& Evolution, v. 11, n. 3, p. 119-124, 1996.

FINEGAN, B. The management potential of neotropical secondary lowland rain forest. Forest Ecology and Management, v. 47, n. 1-4, p. 295-321, 1992.

FRANK, E.; HALL, M.A.; WITTEN, I.H. The WEKA Workbench. Online Appendix for "Data Mining: Practical Machine Learning Tools and Techniques. Morgan Kaufmann, Fourth Edition, 2016.

FRIEDL, M. A. M. A.; BRODLEY, C. E. C. E. Decision tree classification of land cover from remotely sensed data. Remote Sensing of Environment, v. 61, n. 3, p. 399-409, 199

FRIKEL, P. Agricultura dos índios Mundurukus. Belém: Boletim do Museu Paraense Emilio Goeldi, v. 4, 1959.

FRITZ, S. Mapa Geographica del rio Maranõn o Amazonas por el P. Samuel Fritz, de la Compania de Jesus, 1691. Paris: Bibliothèque nationale de France, département Cartes et plans, GE C-5037 (RES). Disponível em: http://catalogue.bnf.fr/ark:/12148/cb40595394d . Acesso em 31 jan. 2017.

FU, K. S.; MUI, J. K. A survey on image segmentation. Pattern Recognition, v. 13, n. 1, p. 3-16, 1981.

FUNAI - Fundação Nacional do Índio. Limites das Terras Indígenas do Brasil. Brasília: FUNAI, 2013.2 Disponível em: http://mapas2.funai.gov.br/portal mapas/shapes/terra indigena.zip Acesso em 31 jan. 2017.

FURTADO, C. O Problema da Mão-de-Obra - Transumância Amazônica. In: Formação Economica do Brasil. São Paulo: Companhia das Letras, 2010

GAO, B.-C. NDWI - A normalized difference water index for remote sensing of vegetation liquid water from space. Remote Sensing of Environment, v. 58, n. 3, p. 257-266, 1996.

GAO, B.-C.; GOETZ, A. F. H. Column atmospheric water vapor retrievals from airborne imaging spectrometer data. Journal of Geophysical Research - Atmospheres, v. 95, n. D4, p. 3549-3564, 1990.

GIBBS, H. K.; RAUSCH, L.; MUNGER, J.; SCHELLY, I.; MORTON, D. C.; NOOJIPADY, P.; SOARES-FILHO, B.; BARRETO, P.; MICOL, L.; WALKER, N. F. Brazil's Soy Moratorium. Science, v. 347, n. 6220, p. 377-378, 2015.

GIBBS, H. K.; RUESCH, a S.; ACHARD, F.; CLAYTON, M. K.; HOLMGREN, P.; RAMANKUTTY, N.; FOLEY, J. a. Tropical forests were the primary sources of new agricultural land in the 1980s and 1990s. Proceedings of the National Academy of Sciences, v. 107, n. 38, p. 16732-16737, 2010.

GOOGLE. My Maps:. Santarem Street View Samples Map. Disponível em: https://www.google.com/maps/d/edit?mid=1Jbr4qKD3DEyjiiJOViFnOEOX6to\&ll=2.981745938322087\%2C-54.41423750000001\&z=9 Acesso em 31 jan 2017. 
GILABERT, M. A.; CONESE, C.; MASELLI, F. An atmospheric correction method for the automatic retrieval of surface reflectances from TM images. International Journal of Remote Sensing, v. 15, n. 10, p. 2065-2086, 1994.

GOMEZ-POMPA, A. Posible Papel de la Vegetacion Secundaria en la Evolucion de la Flora Tropical. Biotropica, v. 3, n. 2, p. 125, 1971

GRACE, J.; MITCHARD, E.; GLOOR, E. Perturbations in the carbon budget of the tropics. Global Change Biology, v. 20, n. 10, p. 3238-3255, 2014.

GREENPEACE.A farra do boi na amazônia: edição resumida. 44 p. 2009. Disponível em: $\quad$ http://www.greenpeace.org/brasi//Global/brasil/report/2009/6/FARRAwebalterada.pdf. Acesso em 31 jan. 2017.

GREENPEACE. Eating up the Amazon. 64 p. 2006. Disponível em: http://www.greenpeace.org/international/Global/international/planet2/report/2006/7/eating-up-the-amazon.pdf Acesso em 31 jan. 2017.

HANSEN, M.; POTAPOV, P.; MARGONO, B.; STEHMAN, S.; TURUBANOVA, S.; TYUKAVINA, A. Response to Comment on "High-resolution global maps of $21 \mathrm{st}$ century forest cover change". Science, v. 344, n. 6187, p. 981-981, 2014.

HANSEN, M. C.; POTAPOV, P. V; MOORE, R.; HANCHER, M.; TURUBANOVA, S. a; TYUKAVINA, A.; THAU, D.; STEHMAN, S. V; GOETZ, S. J.; LOVELAND, T. R.; KOMMAREDDY, A.; EGOROV, A.; CHINI, L.; JUSTICE, C. O.; TOWNSHEND, J. R. G. High-Resolution Global Maps of 21st-Century Forest Cover Change. Science, v. 342, n. 6160, p. 850-853, 15 nov. 2013.

HANSEN, M.; DUBAYAH, R.; DEFRIES, R. Classification trees: an alternative to traditional land cover classifiers. International Journal of Remote Sensing, v. 17, n. 5, p. 1075-1081, 1996.

HARALICK, R.; SHANMUGAN, K.; DINSTEIN, I. Textural features for image classification. IEEE Transactions on Systems, Man and Cybernetics, 1973.

HARVEY, D. Between space and time: reflections on the geographical imagination, AAG, 1990, p.431

HOMMA, A.K.O. A civilização da juta na Amazônia - expansão e declínio.Brasília: Anais do Congresso Brasileiro de Economia e Sociologia Rural, v. 33, p. 509-531, 1995

HUANG, C.; SONG, K.; KIM, S.; TOWNSHEND, J. R. G.; DAVIS, P.; MASEK, J. G.; GOWARD, S. N. Use of a dark object concept and support vector machines to automate forest cover change analysis. Remote Sensing of Environment, v. 112, n. 3, p. 970-985, 2008.

HUETE, A. R. A Soil-Adjusted Vegetation Index (SAVI). Remote Sensing of Environment, v. 25, n.3, p. 205-309, 1988

HUETE, A. R.; LIU, H. Q.; BATCHILY, K.; J., L. van W A Comparison of Vegetation Indices over a Global Set of TM Images for EOS-MODIS. Remote Sensing of Environment, n.59, p.440-451, 1997

HUNT JR, E.R.; ROCK, B.N. Detection of changes in leaf water content using nearand middle-infrared reflectances. Remote Sensing of Environment, v. 30, p. 43-54, 1989 
HUSSAIN, M.; CHEN, D.; CHENG, A.; WEI, H.; STANLEY, D. Change detection from remotely sensed images: From pixel-based to object-based approaches. ISPRS Journal of Photogrammetry and Remote Sensing, v. 80, p. 91-106, 2013.

IANNI, O. A luta pela terra: história social da terra e da luta pela terra numa área da Amazônia. Petrópolis: Vozes, 235 p., 1978

IBRE- Instituto Brasileiro de Economia. Indicadores de preços agopecuários. São Paulo: Fundação Getúlio Vargas, 2016. Disponível em http://portalibre.fgv.br/ Acesso em 31 jan. 2017

IBGE - Instituto Brasileiro de Geografia e Estatística. Estimativa da população do Brasil em 1ㅇ de julho de 2016. Disponível em: ftp://ftp.ibge.gov.br/Estimativas de Populacao/Estimativas 2016/estimativa dou 20 16 20160913.pdf. Acesso em 31 jan. 2017.

IBGE - Instituto Brasileiro de Geografia e Estatística. Base cartográfica integrada digital do Brasil ao milionésimo. Rio de Janeiro: IBGE, 2013. Disponível em: ftp://geoftp.ibge.gov.br/mapeamento sistematico/base continua ao milionesimo Acesso em 31 jan. 2017.

IBGE - Instituto Brasileiro de Geografia e Estatística. Malha Digital Municipal do Pará em 2013. Disponível em: ftp://geoftp.ibge.gov.br/malhas digitais/municipio 2013 Acesso em 31 jan. 2017.

ICMBIO - Instituto Chico Mendes de Conservação da Biodiversidade. Limites das Unidades de Conservação Federais. Brasília: Coordenação de Tecnologia da Informação - $\quad$ COTEC. Disponível em: http://mapas.icmbio.gov.br/i3geo/datadownload.htm. Acesso em 31 jan. 2017.

INCRA - Instituto Nacional de Colonização e Reforma Agrária. Instrução Especial $n^{\circ}$ 20, de 28 de maio de 1980. Estabelece o Módulo Fiscal de cada Município, previsto no Decreto no84.685 de 06 de maio de 1980. Disponível em: http://www.incra.gov.br/media/institucional/legislacao/atos_internos/instrucoes/instruc ao_especial/IE20_280580.pdf. Acesso em 31 jan 2017.

INMET - Instituto Nacional de Meteorologia. Banco de Dados Meteorológicos para Ensino e Pesquisa. Disponível em: http://www.inmet.gov.br/projetos/rede/pesquisa/ Acesso em 23 mai 2017.

INPE - Instituto Nacional de Pesquisas Espaciais. Monitoramento da floresta amazônica brasileira por satélite - Projeto PRODES. São José dos Campos. Disponível em: http://www.obt.inpe.br/prodes Acesso em 31 jan. 2017.

INPE - Instituto Nacional de Pesquisas Espaciais. Catálogo de Imagens. São José dos Campos: INPE - Departamento de Geração de Imagens (DGl). Disponível em: http://www.dgi.inpe.br/CDSR/ Acesso em 31 jan. 2017.

INPE - Instituto Nacional de Pesquisas Espaciais. Levantamento de informações de uso e cobertura da terra na Amazônia - TERRACLASS. Belém: Centro Regional da Amazônia, $2014 . \quad$ Disponível em: http://www.inpe.br/cra/projetos pesquisas/TERRACLASS2012.php Acesso em 31 jan. 2017. 
JAKOVAC, A. C. C. BENTOS, T. V.; MESQUITA, R. C. G.; WILLIAMSON, G. B.Age and light effects on seedling growth in two alternative secondary successions in central Amazonia. Plant Ecology \& Diversity, v. 0874, p. 1-10, 2012.

JACKSON, J. The thief at the end of the world: rubber, power and the seeds of Empire. Nova York: Penguin, 432 p., 2008.

JENSEN, J.R. Sensoriamento remoto do ambiente: uma perspectiva em recursos terestres. Tradução de José Carlos Neves Epiphanio (coord.). São José dos Campos: Parêntese, 598 p., 2009

JEPSON, W. Private agricultural colonization on a Brazilian frontier, 1970-1980. Journal of Historical Geography, v. 32, n. 4, p. 839-863, 2006.

JI, L.; ZHANG, L.; WYLIE, B. K.; ROVER, J. On the terminology of the spectral vegetation index (NIR-SWIR)/(NIR + SWIR). International Journal of Remote Sensing, v. 32, n. 21, p. 6901-6909, 2011.

KALMEGH, S. Analysis of WEKA Data Mining Algorithm REPTree, Simple Cart and RandomTree for Classification of Indian News. IJISET - International Journal of Innovative Science, Engineering \& Technology, Vol 2, Issue 2, p. 438-446 , 2015.

KANTARDZIC, M. Decision Trees and Decision Rules. In: Data Mining. Hoboken, NJ, USA: John Wiley \& Sons, Inc., 2011. p. 169-198.

KATES, R. W.; CLARK, W. C.; CORELL, R.; HALL, J. M.; JAEGER, C. C.; LOWE, I.; MCCARTHY, J. J.; SCHELLNHUBER, H. J.; BOLIN, B.; DICKSON, N. M.; FAUCHEUX, S.; GALLOPIN, G. C.; GRÜBLER, A.; HUNTLEY, B.; JÄGER, J.; NARPAT, S.; KASPERSON, R. E.; MABOGUNJE, A.; MATSON, P.; MOONEY, H.; MOORE, B.; RIORDAN, T. O.; SVEDIN, U.; III, B. M. Sustainability Science. Science (New York, N.Y.), v. 292, n. 5517, p. 641-642, 2001.

KERN, D.C.; D'AQUINO, G.; RODRIGUES, T. E.; FRAZAO, F. J. L.; SOMBROEK, W.; MYERS, T. P.; NEVES, E. G. Distribution of Amazonian Dark Earths in the Brazilian Amazon. In: LEHMANN, J.; KERN, D. C.; GLASER, B.; WODOS, W. I. (org.) Amazonian Dark Earths: origin, properties, management. Dordrecht: Springer Netherlands. p.51-75, 2003.

KEY, C.H.; BENSON, C.B. Measuring and remote sensing of burn severity: the CBI and NBR. In Proceedings Joint Fire Science Conference and Workshop, vol. II, 15-17 June 1999, L.F. Neuenschwander and K.C. Ryan (Eds.), Boise, ID, p. 284 (Boise, ID: University of Idaho and International Association of Wildland Fire), 1999.

KOHLEPP, G. Conflitos de interesse no ordenamento territorial da Amazônia brasileira. Estudos Avançados, v.16, n. 45, 2002

LAURANCE, W. F.; CAMARGO, J. L. C.; LUIZÃO, R. C. C.; LAURANCE, S. G.; PIMM, S. L.; BRUNA, E. M.; STOUFFER, P. C.; BRUCE WILLIAMSON, G.; BENÍTEZMALVIDO, J.; VASCONCELOS, H. L.; VAN HOUTAN, K. S.; ZARTMAN, C. E.; BOYLE, S. a.; DIDHAM, R. K.; ANDRADE, A.; LOVEJOY, T. E. The fate of Amazonian forest fragments: A 32-year investigation. Biological Conservation, v. 144, n. 1, p. 56-67, 2011.

LU, D.; MAUSEL, P.; BRONDÍZIO, E.; MORAN, E. Classification of successional forest stages in the Brazilian Amazon basin. Forest Ecology and Management, v. 181, n. 3, p. 301-312, 2003. 
LU, D.; MORAN, E.; BATISTELLA, M. Linear mixture model applied to Amazonian vegetation classification. Remote Sensing of Environment, v. 87, n. 4, p. 456-469, 2003.

LUCAS, R. M.; HONZAK, M.; FOODY, G. M.; CURRAN, P. J.; CORVES, C. Characterizing tropical secondary forests using multi-temporal LANDSAT sensor imagery. International Journal of Remote Sensing, v. 14, n. 16, p. 3061-3067, 1993.

LUGO, A. E. Successional or Steady State. Biotropica, v. 12, n. 2, p. 65-72, 1980.

MARTINS, J.S. O Cativeiro da Terra. São Paulo: Contexto, 288 p., 2010.

MASSOCA, P.E.S.; JAKOVAC, A.C.C.; BENTOS, T.V.; WILLIAMSON, G.B.; MESQUITA, R.C.G. Dinâmica e trajetórias da sucessão secundária na Amazônia central Dynamics and trajectories of secondary succession in Central Amazonia. Bol. Mus. Para. Emílio Goeldi, v. 7, n. 3, p. 235-250, 2012.

MATHER, P.M. Computer processing of remotely-sensed images: an introduction. Nova lorque: Wiley \& Sons, 352 p., 1987.

MAUSEL, P.; WU, Y.; LI, Y.; MORAN, E. F.; BRONDIZIO, E. S. Spectral identification of successional stages following deforestation in the Amazon. Geocarto International, v. 8, n. 4, p. 61-71, 1993.

MENEZES, D.P. Caracterização física, esboço morfológico e aspecos morfométricos da planície fluvial do rio Tietê em Biritiba-Mirim - SP. Universidae de São Paulo: monografia, 122 p. 2006

MEGGERS, B. J. Reconstrução do Comportamento Locacional Pré-Histórico na Amazônia. Boletim do Museu Paraense Emílio Goeldi, Antropologia, v. 6(2): p. 183-20, 1990.

MELLO, A. Y. I.; ALVES, D. S. Secondary vegetation dynamics in the Brazilian Amazon based on thematic mapper imagery. Remote Sensing Letters, v. 2, n. 3, p. 189-194, 2011.

MIERSWA, I.; WURST, M.; KLINKENBERG, R.; SCHOLZ, M.; EULER, T. YALE: Rapid Prototyping for Complex Data Mining Tasks. In: Proceedings of the 12th ACM SIGKDD international conference on Knowledge discovery and data mining - KDD '06, New York, New York, USA. Anais... New York, New York, USA: ACM Press, 2006

MILLENIUM ECOSYSTEM ASSESTMENT. Ecosystems and human well-being: a synthesis. Millenium Ecosystem Assestment Series. World Resources Institute-Island Press, 137 p. 2005

MMA - Ministério do Meio Ambiente. Instrução Normativa $n^{\circ} 02$, de 06 de maior de 2014. Dispõe sobre os procedimentos para a integração, execução e compatibilização do Sistema de Cadastro Ambiental Rural-SICAR e define os procedimentos gerais do Cadastro Ambiental Rural-CAR

MORAN, E. F. Pioneer farmers of the transamazon hihgway: adaptation and agricultural production in the lowland tropics. [s.l.] University of Florida, 1975

MORAN, E.F.; BONDIZIO, E. Land-use change after deforestation in Amazonia. In: People and pixels: linking Remote Sensing and Social Science, 1998, p.94. 
MOREIRA NETO, C.A. índios na Amazõnia: de maioria a minoria (1750-1850). Petrópolis: Vozes, 348 p., 1988

MOTA, G.; PAKZAD, K.; MULLER, S. A Framework for Automatic Low-Resolution Satellite Image Interpretation Based on Spectral, Contextual and Multitemporal Knowledge. 2004.

MUZELI, E. Fordlândia - o filme. Arquivo de imagens antigas - Fordlândia e Belterra. 2011. Disponível em: http://www.fordlandia.com.br/Fordlandia/Fotos antigas.html\#16 Acesso em 31 jan 2017.

NASSAR, R. Lavoura Arcaica. São Paulo; Companhia das Letras, 1989.

NEFF, T. Area and age of secondary forests in Brazilian Amazonia 1978-2002: An empirical estimate. Ecosystems, v. 9: p. 609-623. 2006

NETTO, D. Transmazônica povoará a selva. In: O Estado de São Paulo, Geral, p.34 19 de junho de 1970.

NEPSTAD, D. MCGRATH, D.; STICKLER, C.; ALENCAR, A.; AZEVEDO, A.; SWETTE, B.; BEZERRA, T.; DIGIANO, M.; SHIMADA, J.; SEROA DA MOTTA, R.; ARMIJO, E.; CASTELLO, L.; BRANDO, P.; HANSEN, M. C.; MCGRATH-HORN, M.; CARVALHO, O.; HESS, L. Slowing Amazon deforestation through public policy and interventions in beef and soy supply chains. Science, v. 344, n. 6188, p. 1118-1123, 2014.

NIMUEDAJÚ, C. Mapa etno-histórico do Brasil e regiões adjacentes. Escala 1:2.500.000. Rio de Janeiro: IBGE, 2 $2^{\mathrm{a}}$ impressão, 1987 Disponível em: http://biblioteca.ibge.gov.br/visualizacao/livros/liv14278 mapa.pdf Acesso em 31 jan. 2017.

NIMUNEDAJÚ, C. The Tapajó. Kroeber Antrhopological Society Papers, v. 6, p. 1-25., 1952

NOBRE, C. A.; SAMPAIO, G.; BORMA, L. S.; CASTILLA-RUBIO, J. C.; SILVA, J. S.; CARDOSO, M. Land-use and climate change risks in the Amazon and the need of a novel sustainable development paradigm. Proceedings of the National Academy of Sciences, p. 201605516, 2016.

NOVO, E.M.LM. Sensoriamento remoto: princípios e aplicações. São Paulo: Blucher, $3^{\mathrm{a}}$ ed, 363 p. 2008.

OBSERVATÒRIO DO CLIMA. MAPBIOMAS: Projeto de Mapeamento Anual da Cobertura e Uso do Solo. 2015. Disponível em: http://mapbiomas.org/ Acesso em 31 jan 2017.

PAKZAD, K.; MOTA, G.L.A.; MEIRELLES, M.S.; COUTINHO, H.L.C.; FEITOSA,R.Q. Automatic Interpretation of Vegetation Areas in Brazil. Proceedings of the Joint Workshop of ISPRS Working Groups I/2, I/5, IC WG II/IV and the EARSeL Special Interest Group 3D Remote Sensing, 2003.

PANDYA, M. R.; MURALI, K. R.; KIRANKUMAR, A. S. Quantification and comparison of spectral characteristics of sensors on board Resourcesat-1 and Resourcesat-2 satellites. Remote Sensisng Letters, 4:3, p. 306-314, 2013. 
PARÁ. Instrução Normativa da Secretaria de Estado do Meio Ambiente N08, de 28 de outubro de 2015 - DOEPA 33003 de 03 de novembro de 2015 Define procedimentos administrativos para a realização de limpeza e autorização de supressão, a serem realizadas nas áreas de vegetação secundária em estágio inicial de regeneração, localizadas fora da Reserva Legal e da Área de Preservação Permanente - APP dos imóveis rurais, no âmbito do Estado do Pará, e dá outras providências

PARÁ. Instrução Normativa da Secretaria de Estado do Meio Ambiente N02, de 26 de fevereiro de 2014 - DOEPA 32594 de 28 de fevereiro de 2014. Define procedimentos administrativos para a realização de limpeza e para a obtenção de autorização de supressão, a serem realizadas nas áreas de vegetação secundária em estágio inicial de regeneração, localizadas fora da Reserva Legal e da Área de Preservação Permanente - APP dos imóveis rurais, no âmbito do Estado do Pará, e dá outras providências.

PEARSON, H. (org). The Rubber Situation in Bolivia. In: India Rubber World. The India Rubber Publishing Co, v. 27, n. 1, p.15. 1ํㅡㄴ Out 1902. Disponível em https://archive.org/stream/indiarubberworld26phil\#page/15/mode/1up Acesso em 31 jan. 2017.

PERES, C. A.; GARDNER, T. a.; BARLOW, J.; ZUANON, J.; MICHALSKI, F.; LEES, A. C.; VIEIRA, I. C. G.; MOREIRA, F. M. S.; FEELEY, K. J. Biodiversity conservation in human-modified Amazonian forest landscapes. Biological Conservation, v. 143, n. 10, p. 2314-2327, 2010.

PERES, C. A.; BARLOW, J.; HAUGAASEN, T. Vertebrate responses to surface wildfires in a central Amazonian forest. Oryx, v. 37, n. 1, p. 97-109, 2003.

PERES, C. A. Synergistic Effects on Amazonian Forest Vertebrates Fragmentation. Conservation Biology, v. 15, n. 6, p. 1490-1505, 2001.

PIAZZA, G. A.; VIBRANS, A. C.; LIESENBERG, V.; REFOSCO, J. C. Object-oriented and pixel-based classification approaches to classify tropical successional stages using airborne high-spatial resolution images. GIScience \& Remote Sensing, v. 53, n. 2, p. 206-226, 2016.

PONZONI, F; SHIMABUKURO, Y. Sensoriamento Remoto da Vegetação. São José dos Campos: Parêntese, Edição 2009, 127 p. 2009

POORTER, L. et al. Biomass resilience of Neotropical secondary forests. Nature, v. 530, n. 7589, p. 211-214, 2016.

QUINLAN, R. J. C4.5: Programs for Machine Learning. San Mateo: Morgan Kaufmann Publishers, 1993.

RADAMBRASIL. Folha SA. 21 Santarém: geologia, geomorfologia, pedologia, vegetação, uso potencial da terra. Rio de Janeiro: Departamento Nacional da Produção Mineral, 510 p. il. 1976

RAPIDMINER. Rapidminer Studio 7.5.001 (rev: bbe634, plataform WIN64), 2017. Disponível em: https://rapidminer.com/products/studio/ Acesso em 23 mai 2017I

RIBEIRO, M. B. N.; BRUNA, E. M.; MANTOVANI, W. Influence of Post-Clearing Treatment on the Recovery of Herbaceous Plant Communities in Amazonian Secondary Forests. Restoration Ecology, v. 18, n. SUPPL. 1, p. 50-58, 2010. 
RICHARDS, P.W. Some problems of nature conservation in the tropics. In: Bulletin du Jardin Botanique National de Belgique. 1971, p. 171.

RISSO, J.; RIZZI, R.; FRIEDRICH, B.; RUDORFF, T.; FORMAGGIO, A. R. Potencialidade dos índices de vegetação EVI e NDVI dos produtos MODIS na separabilidade espectral de áreas de soja. XIV Simpósio Brasileiro de Sensoriamento Remoto, p. 379-386, 2009.

RODRIGUES, E. L. Avaliação da cobertura vegetal por meio dos índices de vegetação RODRIGUES, J.B. Exploração e estudo do valle do Amazonas: Rio Tapajós. Rio de Janeiro: Typografia Nacional, $1875 . \quad$ Disponível em: http://www.brasiliana.usp.br/handle/1918/7878 Acesso em 31 jan. 2017.

ROUSE, J. W.; HASS, R. H.; SCHELL, J. A.; DEERING, D. W. Monitoring vegetation systems in the great plains with ERTS. Third Earth Resources Technology Satellite (ERTS) symposium, v. 1, p. 309-317, 1973.

ROY, D. P.; BOSCHETTI, L.; TRIGG, S. N. Remote sensing of fire severity: Assessing the performance of the normalized burn ratio. IEEE Geoscience and Remote Sensing Letters, v. 3, n. 1, p. 112-116, 2006.

SAFIER, N. Como era ardiloso o meu francês: Charles-Marie de la Condamine e a Amazônia das Luzes. In: Revista Brasileira de História, v. 29, n. 57, p. 91-114, 2009.

SATO, L. Y.; SHIMABUKURO, Y. E.; KUPLICH, T. M.; GOMES, V. C. F. Análise comparativa de algoritmos de árvore de decisão do sistema WEKA para classificação do uso e cobertura da terra. Simpósio Brasileiro de Sensoriamento Remoto, p. 23532360, 2013.

SANTOS. R. História econômica da Amazônia. São Paulo; T.A. Queiroz, 1980.

SIMÕES, M. F. A pré-história da bacia amazônica: uma tentativa de reconstrução. In: DIAS, O.(org.). Aspectos da arqueologia amazônica. Rio de Janeiro: Instituto de Arqueologia Brasileira, (Série Catálogo, v. 2). p. 5-21, 1981-1982. Disponível em: http://www.arqueologia-iab.com.br/publications/download/72 Acesso em 31 jan 2017.

SOARES-FILHO, B.; RAJÃO, R.; MACEDO, M.; CARNEIRO, A.; COSTA, W.; COE, M.; RODRIGUES, H.; ALENCAR, A. Cracking Brazil 's Forest Code. Science, v. 344, n. April, p. 363-364, 2014.

SOMRBOEK, W. G. Amazon soils: A Reconnaissance of the Soils of the Brazilian Amazon Region. Wageningen, Center for Agricultural Publications and Documentation. 292 p., 1966.

SOUZA, C. M.; SIQUEIRA, J. V.; SALES, M. H.; FONSECA, A. V.; RIBEIRO, J. G.; NUMATA, I.; COCHRANE, M. A.; BARBER, C. P.; ROBERTS, D. A.; BARLOW, J. Ten-Year Landsat Classification of Deforestation and Forest Degradation in the Brazilian Amazon. Remote Sensing, v. 5, n.11, p. 5493-5513, 2013

SOUZA, C. M.; ROBERTS, D. A.; COCHRANE, M. A. Combining spectral and spatial information to map canopy damage from selective logging and forest fires. Remote Sensing of Environment. 98, p. 329-343, 2005

STOJANOVA, D.; PANOV, P.; GJORGJIOSKI, V.; KOBLER, A.; DZEROSKI, S. Estimating vegetation height and canopy cover from remotely sensed data with machine learning. Ecological Informatics, v. 5, n. 4, p. 256-266, 2010. 
TAUSSIG, M. Shamanism: a study in colonialism, and terror and the wild man healing. Chicago. Chicago University Press, 517 p., 1987.

TROPEK, R.; BECK, J.; KEIL, P.; MUSILOVÁ, Z.; IRENA, Š.; STORCH, D. Comment on "High-resolution global maps of 21st-century forest cover change ". Science, v. 344, n. 6187, p. $981-d, 2014$.

TRIMBLE. ECOGNITION Developer 9.2 Reference Book. Trimble Documentation, 416 p, 2016

UNITED NATIONS WORLD COMMSIION ON ENVIRONMENT AND DEVELOPMENT. Our common future (Brundtland Report). Geneva: United Nations, 300 p, 1987. Disponível em: http://www.un-documents.net/our-common-future.pdf

USGS. LANDSAT Web Page. Disponível em: https://landsat.usgs.gov/ Acesso em 31 jan. 2017.

USGS. Provisional Landsat 8 Surface Reflectance Code Product Guide, set 2016 Disponível em:https://landsat.usgs.gov/sites/defaultfiles/documents/provisional lasrc produ ct guide.pdf Acesso em 31 jan 2017.

USGS-EROS - U.S. Geological Survey's Earth Resources Observation and Science EARTHEXPLORER Catalog. Disponível em: http://EARTHEXPLORER.usgs.gov/ Acesso em 31 jan. 2017.

VALBUENA, R. Santarém, entre la Amazonia de los ríos y la Amazonia de las carreteras. Confins, v. 3, n. 3, p. 195-218, 24 abr. 2008.

VARGAS, G. Discurso do Rio Amazonas. In: Revista Brasileira de Geografia; Rio de Janeiro: IBGE , v.4 n. 2, p 260, 1942

VASQUEZ, M.L.; ROSA-COSTA, L.T. Geologia e recursos minerais do estado do Pará. SIG: texto explicativo dos mapas geológico e tectônico e de recursos minerais do estado do Pará. Belém: Companhia de Recursos Minerais (CPRM), 328 p., 2008.

VENTURIERI A. (org). Mapa de Gestão do ZEE - Zoneamento Ecológico-Econômico da Rodovia BR-163. Escala 1:2.500.000. Belém: Embrapa Amazônia Oriental, 2008. Disponível em: http://zeebr163.cpatu.embrapa.br/index.php Acesso em 31 jan. 2017.

VERBURG, R.; FILHO, S. R.; LINDOSO, D.; DEBORTOLI, N.; LITRE, G.; BURSZTYN, $M$. The impact of commodity price and conservation policy scenarios on deforestation and agricultural land use in a frontier area within the Amazon. Land Use Policy, v. 37, p. 14-26, 2014.

VERMOTE, E. F.; TANRÈ, D.; DEUZÈ, J.L.; HERMAN, M.; MORCRETTE, J.J.; KOTCHENOVA, S.Y. Second Simulation of a Satellite Signal in the Solar Spectrum Vector (6SV) Manual Part 1. Modis Land Surface Reflectance, 2006. Disponível em: http://6s.Itdri.org/files/tutorial/6S_Manual_Part_1.pdf . Acesso em 17 abr 2017.

VERMOTE, E. F.; SALEOUS, N. Z. EL; JUSTICE, C. O. Atmospheric correction of MODIS data in the visible to middle infrared: First results. Remote Sensing of Environment, v. 83, n. 1-2, p. 97-111, 2002. 
VON MARTIUS, C.F. Die ehemalige Verbreitung und die muthmasslichen Wanderungen der Tupis. In: Beiträge zur Ethnographie und Sprachenkunde Amerikas zumal Brasiliens. I. Zur Ethnographie. II. Glossaria linguarum Brasiliensium. Leipzig: Friedrich Fleischer, 1867. Disponível na Biblioteca Digital Curt Nimuendajú em: http://www.etnolinguistica.org/local--files/imagem:1/Martius.jpg Acesso em 23 mai 2017.

WALTER, V. Object-based classification of remote sensing data for change detection. ISPRS Journal of Photogrammetry and Remote Sensing, v. 58, n. 3-4, p. 225-238, 2004.

WEINSTEIN, B. A borracha na Amazõnia: expansão e decadência, 1850 - 1920. São Paulo, Hucitec/Edusp, 374 p, 1993.

WHITE, L. J. T.; OATES, J. F. New data on the history of the plateau forest of Okomu, southern Nigeria: an insight into how human disturbance has shaped the African rain forest. Global Ecology and Biogeography, v. 8, n. 5, p. 355-361, 1999.

WILLIAMS, M. Deforesting the earth:from prehistory to global crisis: an abridgment. Chicago University Press, 543 p, 2006.

WILSON, E. H.; SADER, S. A. Detection of forest harvest type using multiple dates of Landsat TM imagery. Remote Sensing of Environment, v. 80, n. 3, p. 385-396, 2002.

WINKLERPRIS, A. Jute cultivation in the Lower Amazon, 1940-1990: an ethnographic account from Santarém, Pará, Brazil. Journal of Historical Geography, v.37, p.818838, 2006.

YOON, G.; CHO, S. I.; JEONG, S.; PARK, J. Object oriented classification using LANDSAT images. In Proceedings of the 24th Asian conference on remote sensing, Busan, South Korea, 3-7 November, p. 1-3, 2003.

ZHANG, C.; LI, W.; TRAVIS, D. Gaps-fill of SLC-off LANDSAT ETM+ satellite image using a geostatistical approach. International Journal of Remote Sensing, v. 28, n. 22, p. 5103-5122, 2007.

ZHOU, W.; HUANG, G.; TROY, A.; CADENASSO, M. L. Object-based land cover classification of shaded areas in high spatial resolution imagery of urban areas: A comparison study. Remote Sensing of Environment, v. 113, n. 8, p. 1769-1777, 2009. 


\section{APÊNDICE 1. ÁRVORES DE DECISÃO CRIADAS NO WEKA PARA AS CLASSIFICAÇÕES DE 1986, 1995, 2006, 2012, 2015 E 2016}

\section{CLASSIFICAÇÃO DE 1986}

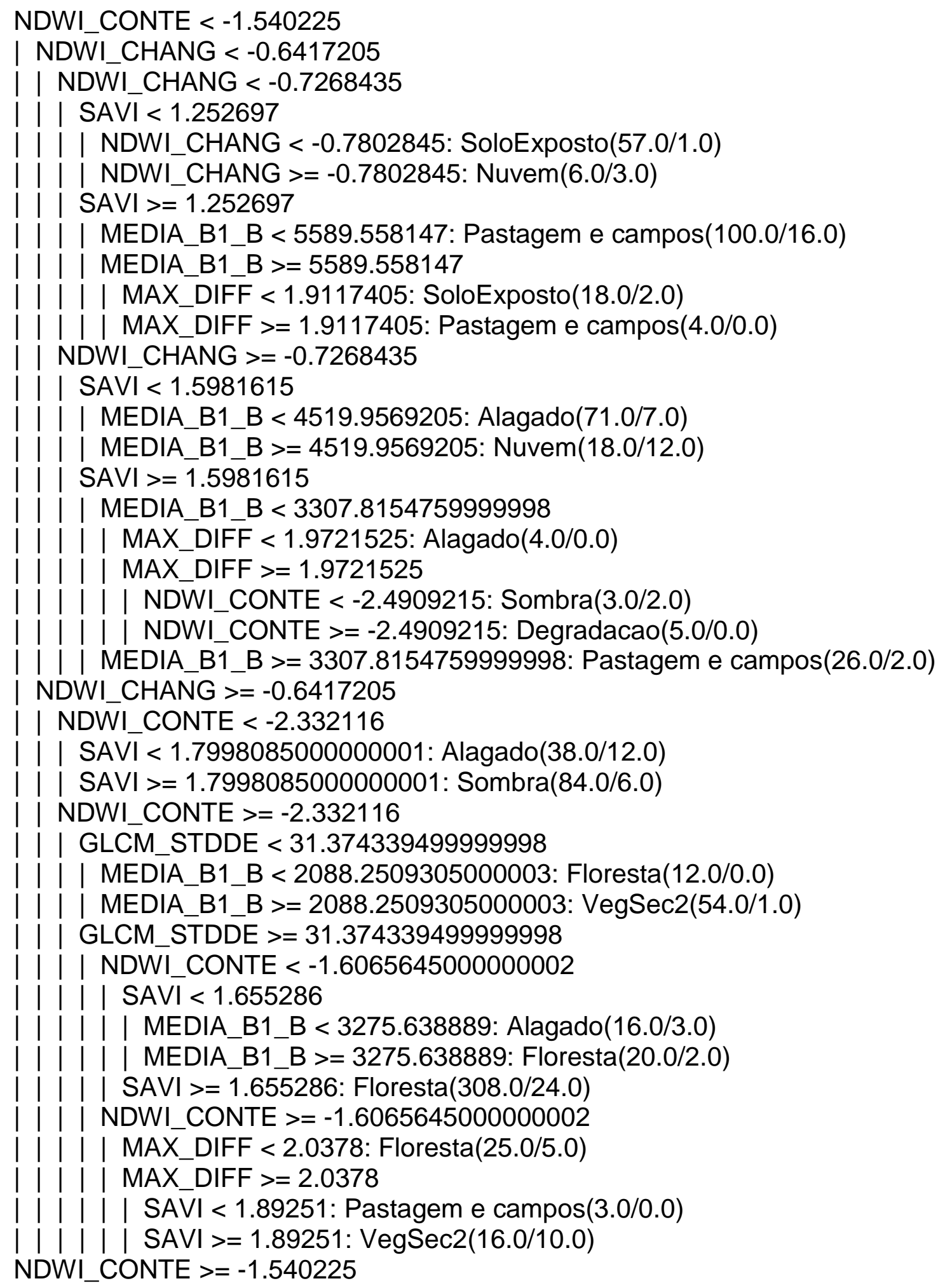




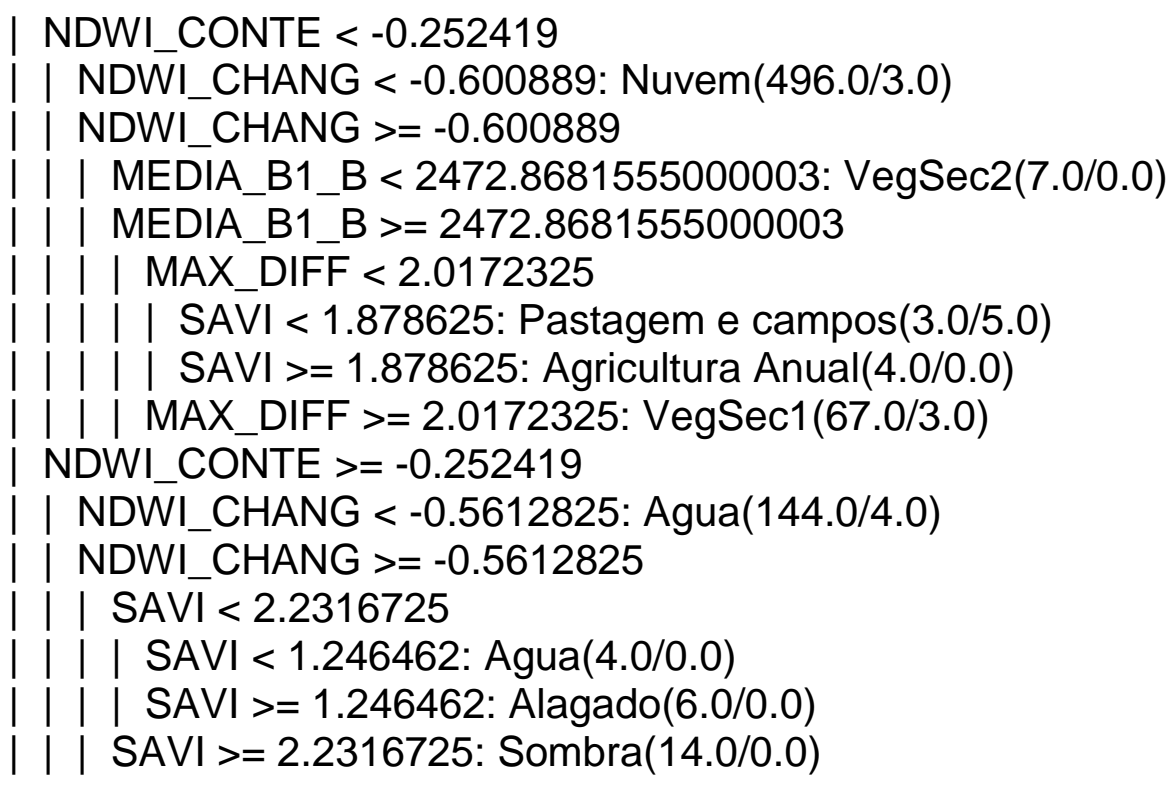

\section{CLASSIFICAÇÃO DE 1995}

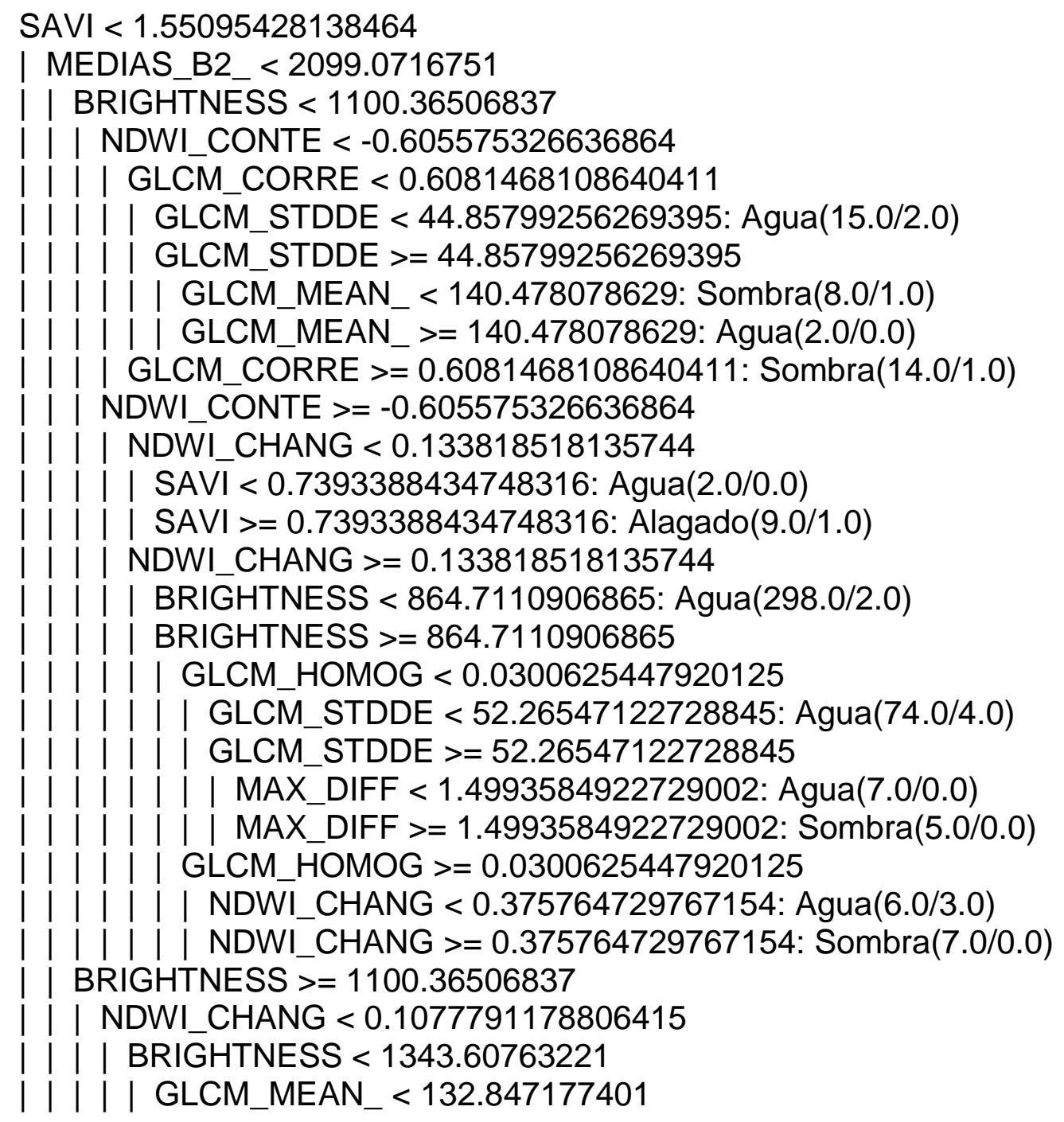




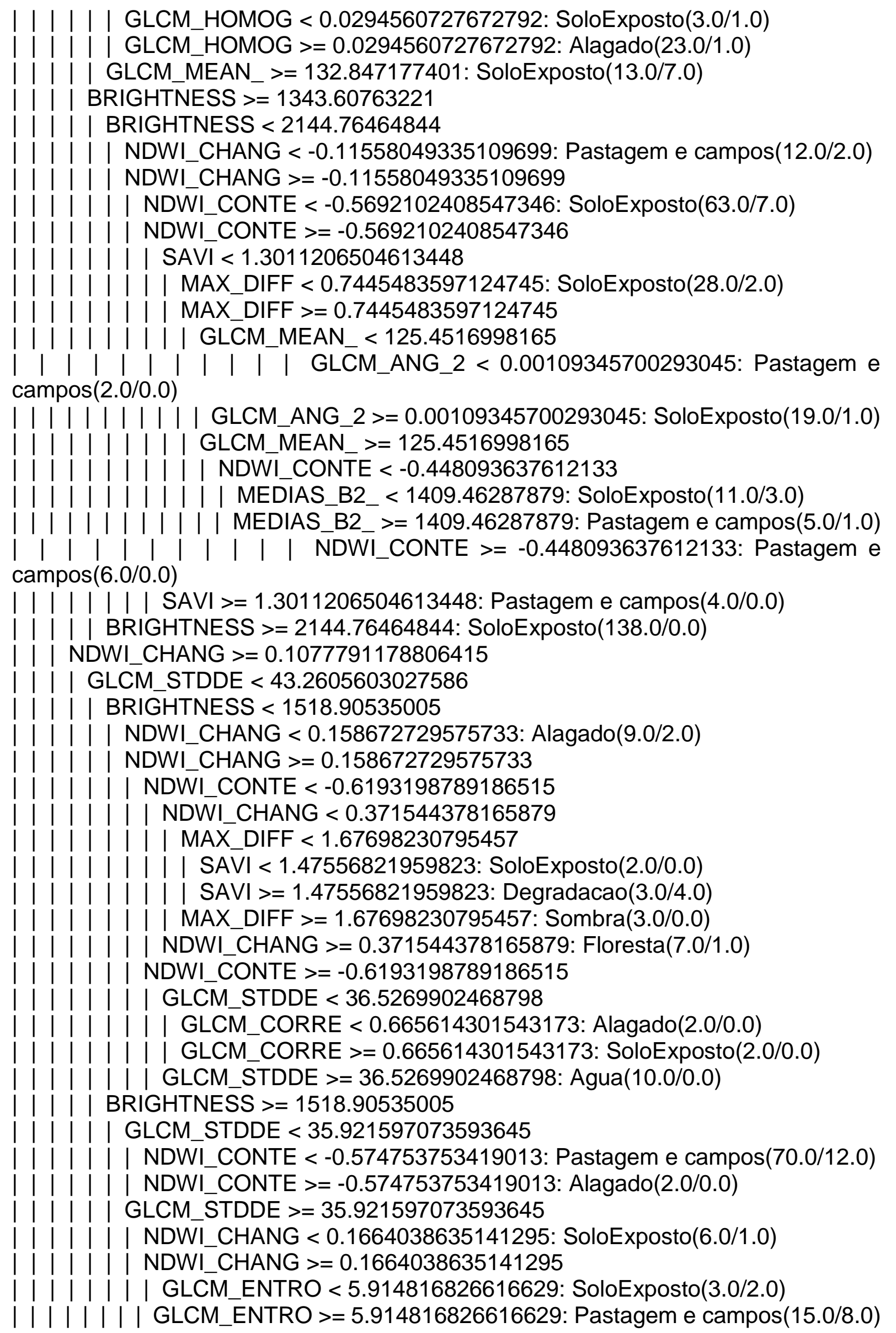




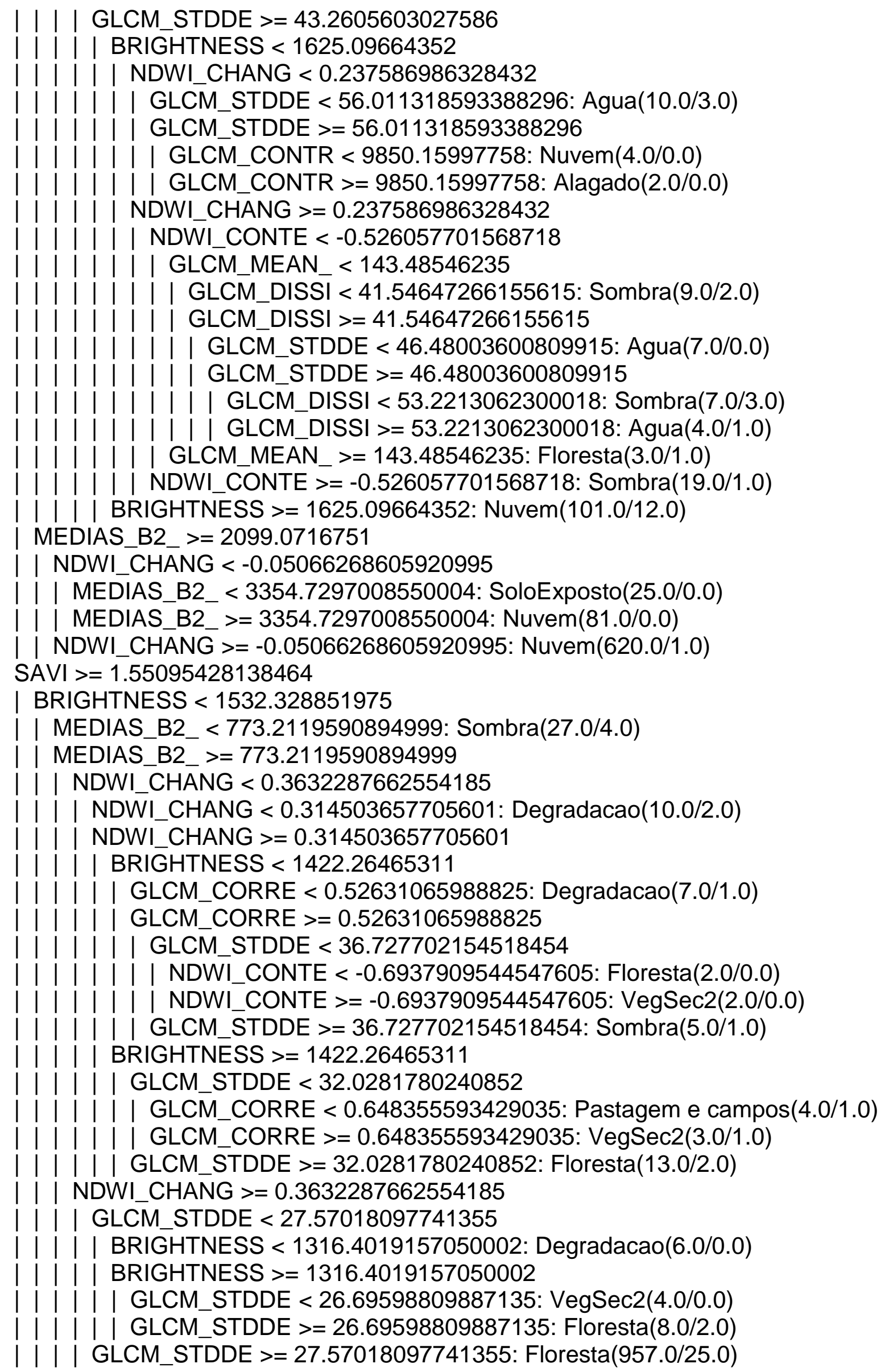




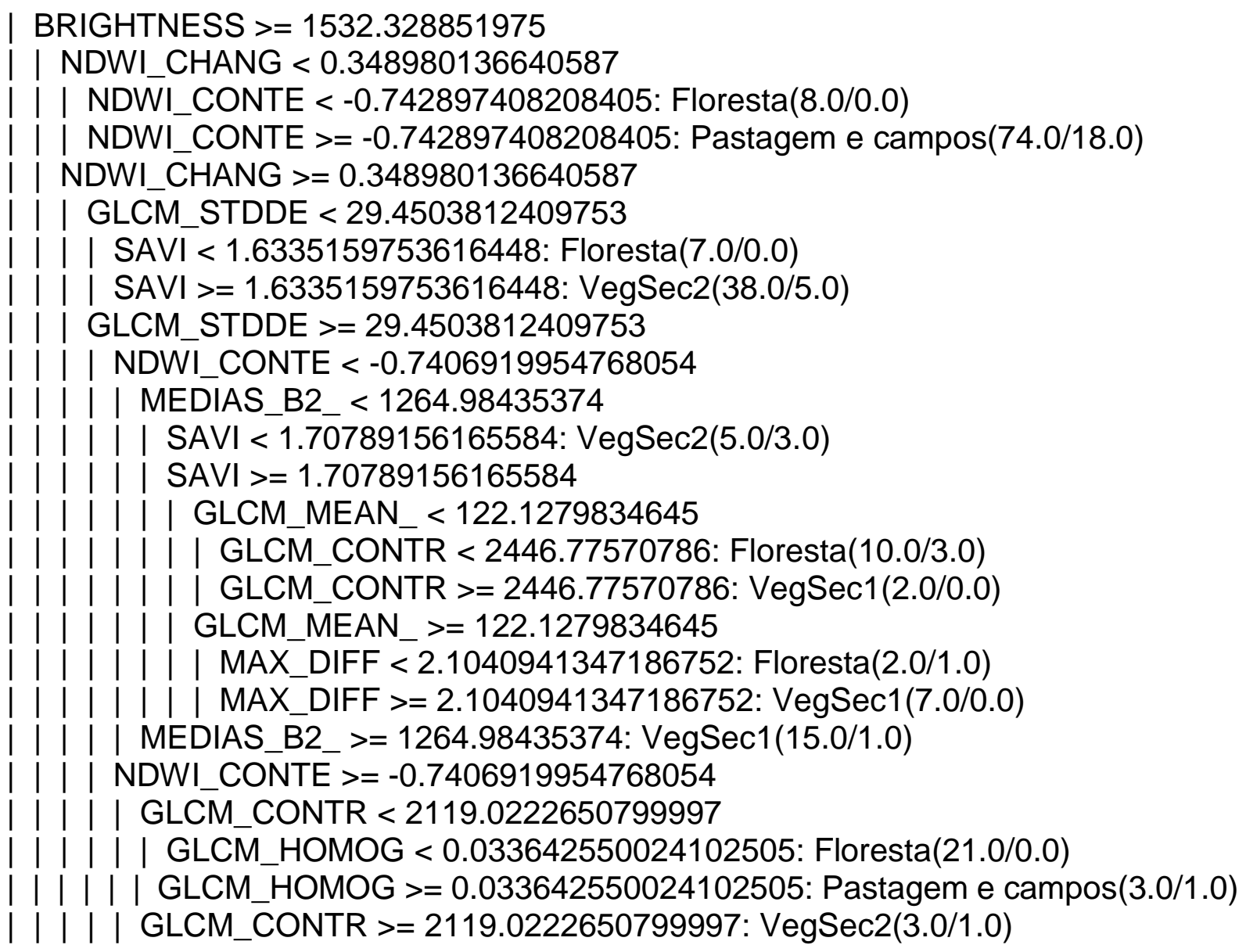

\section{CLASSIFICAÇÃO DE 2006}

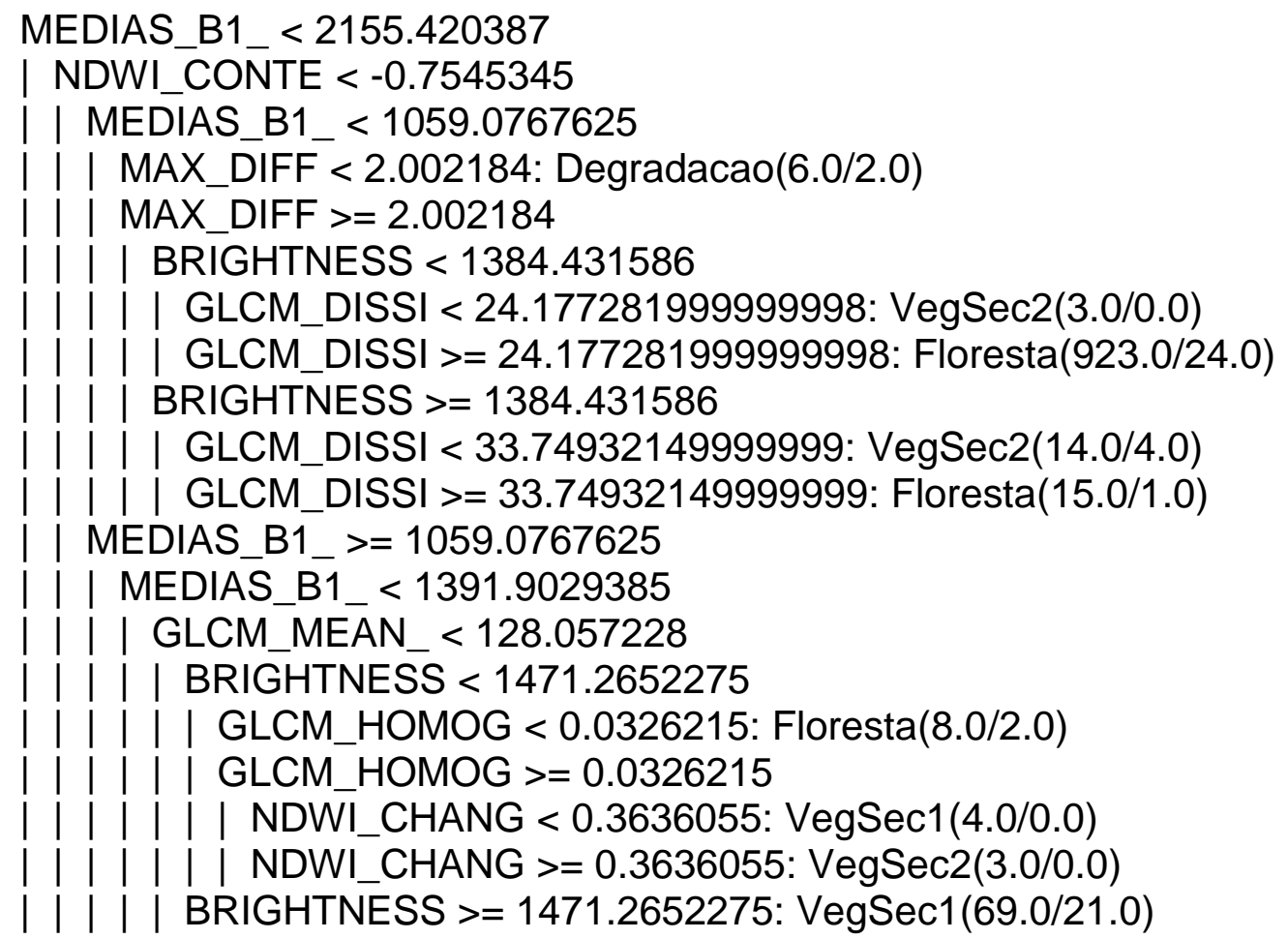




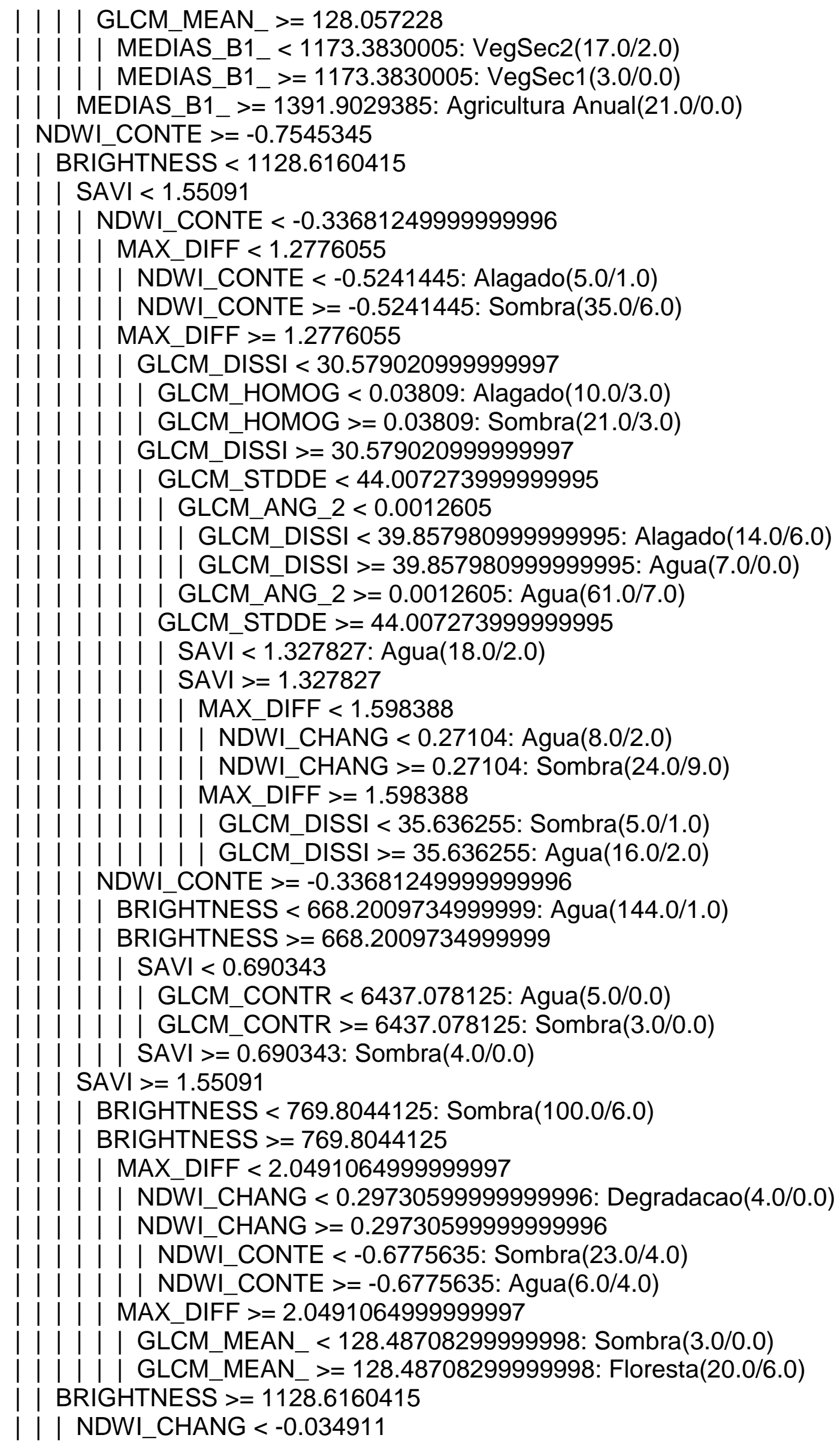




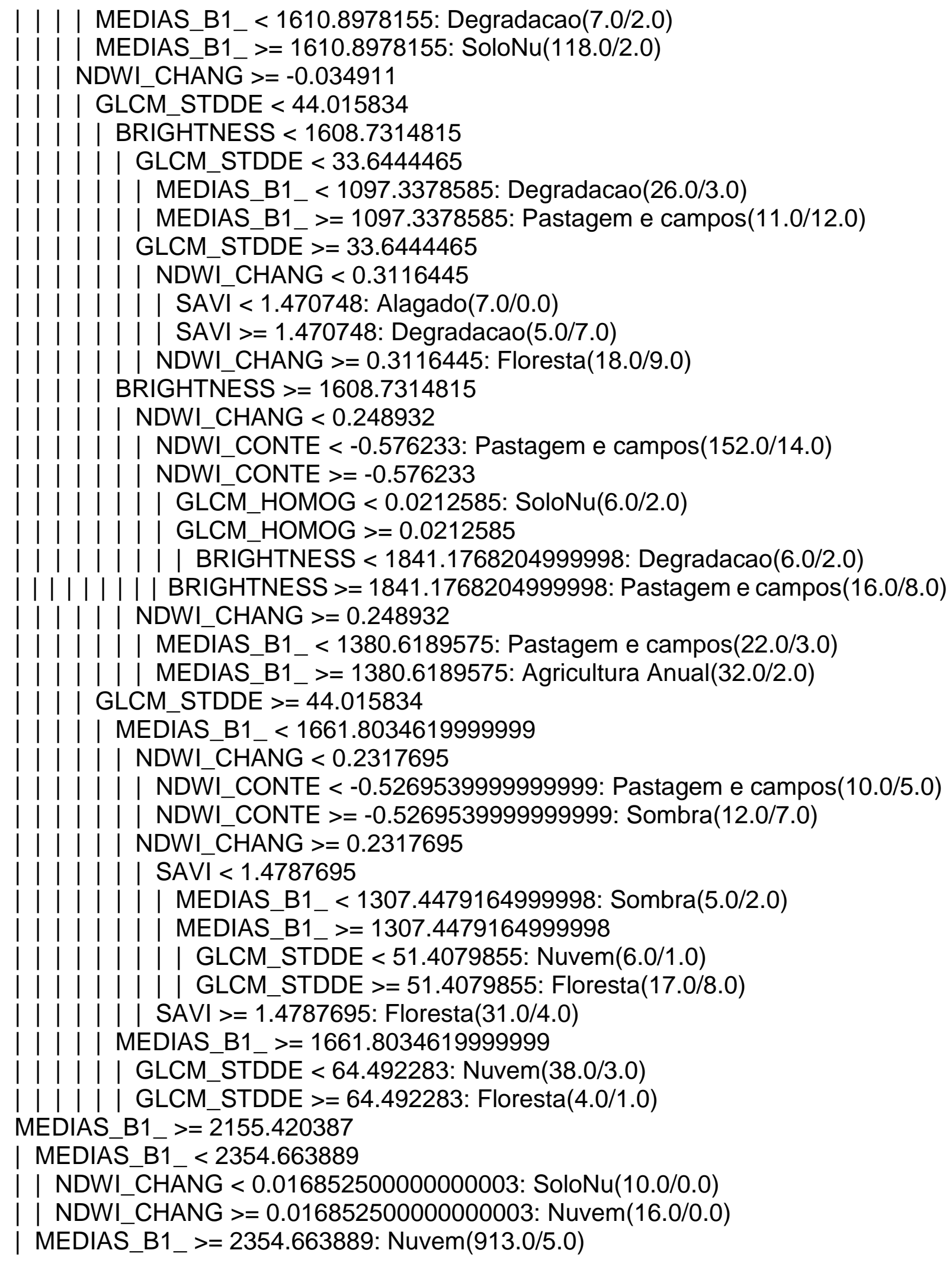




\section{CLASSIFICAÇÃO DE 2012}

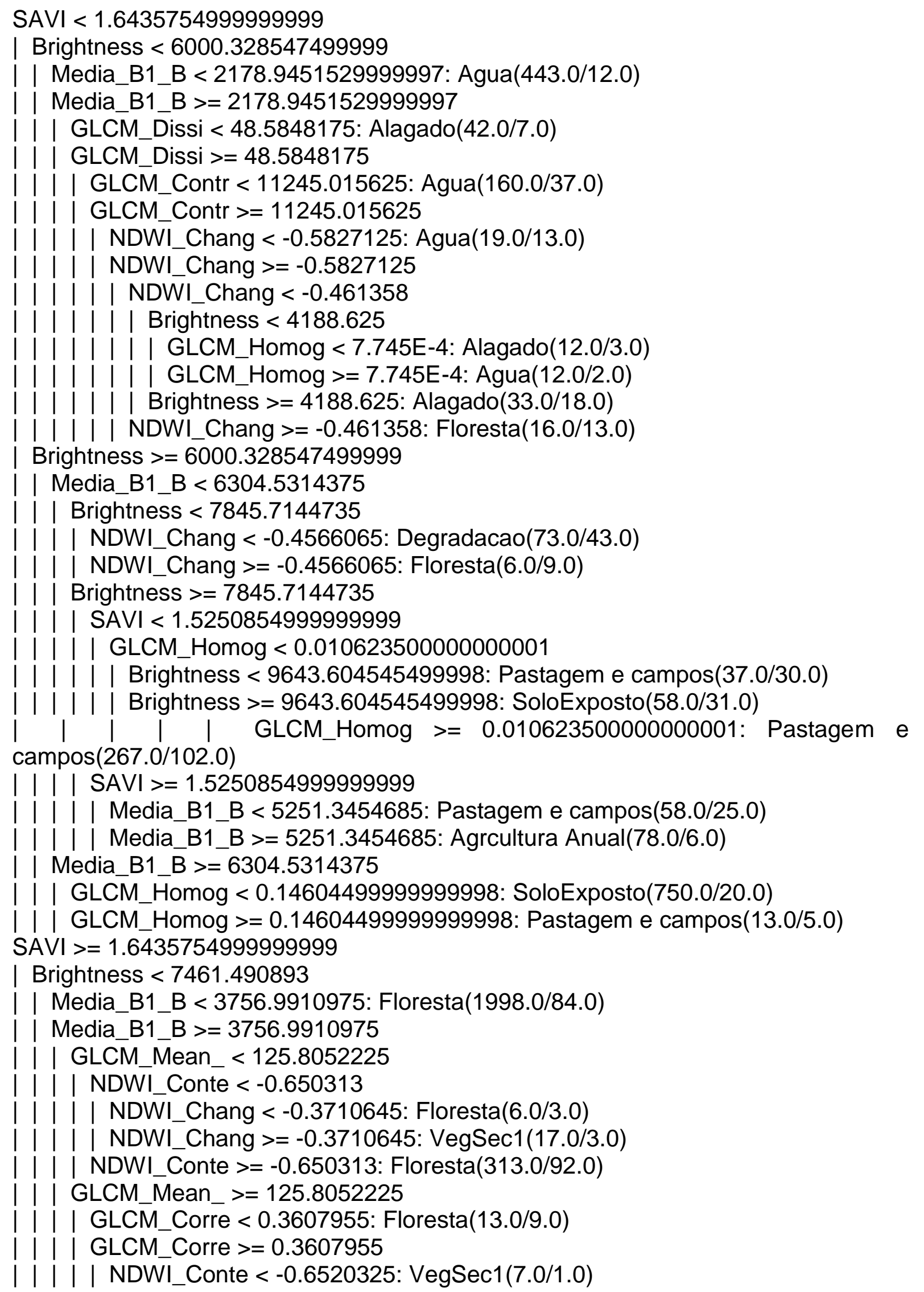




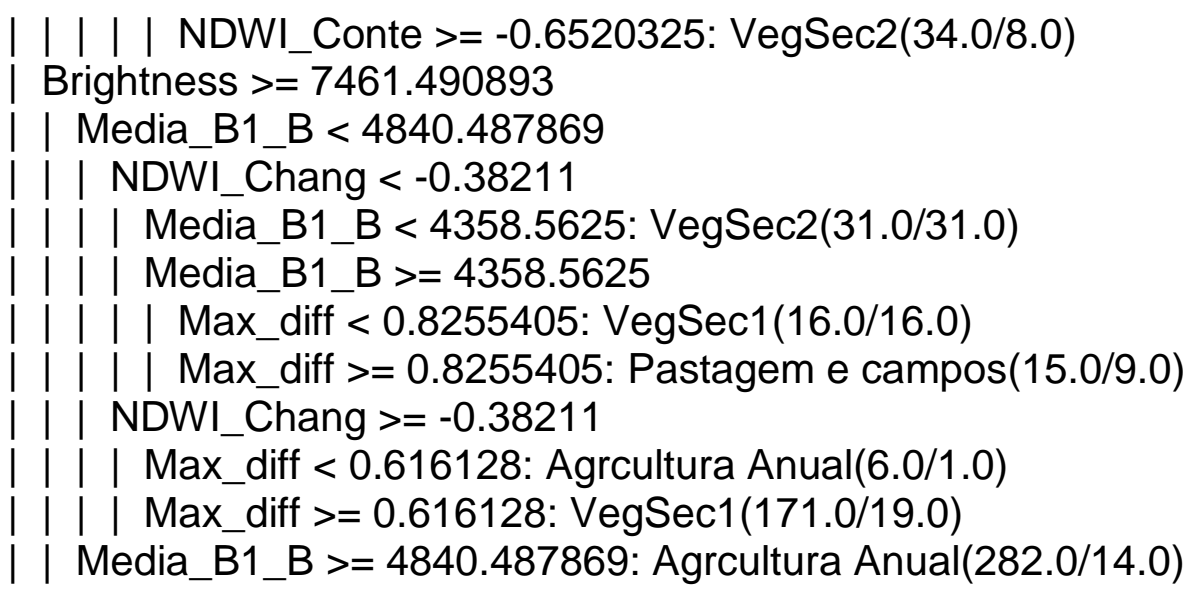

\section{CLASSIFICAÇÃO DE 2015}

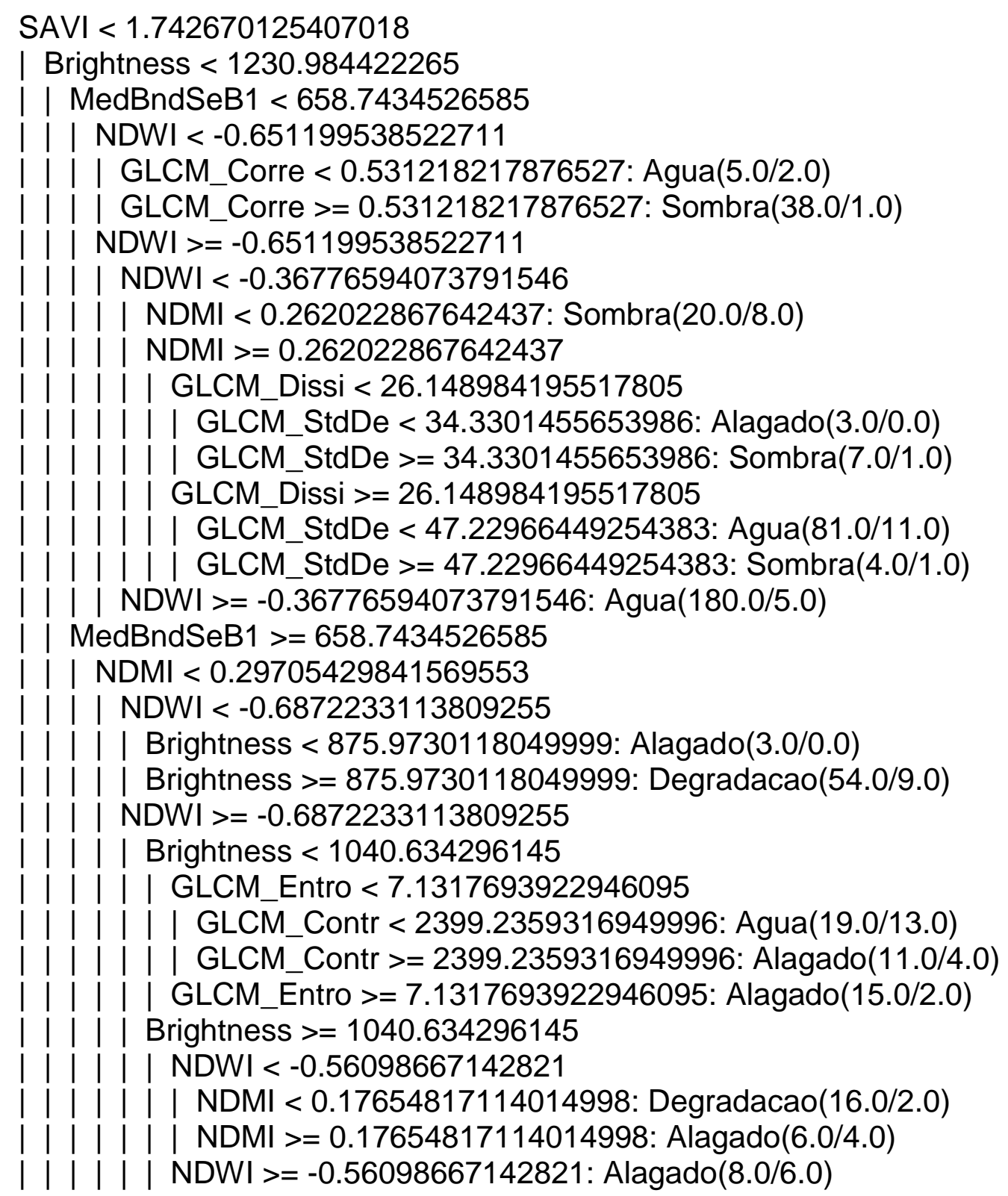




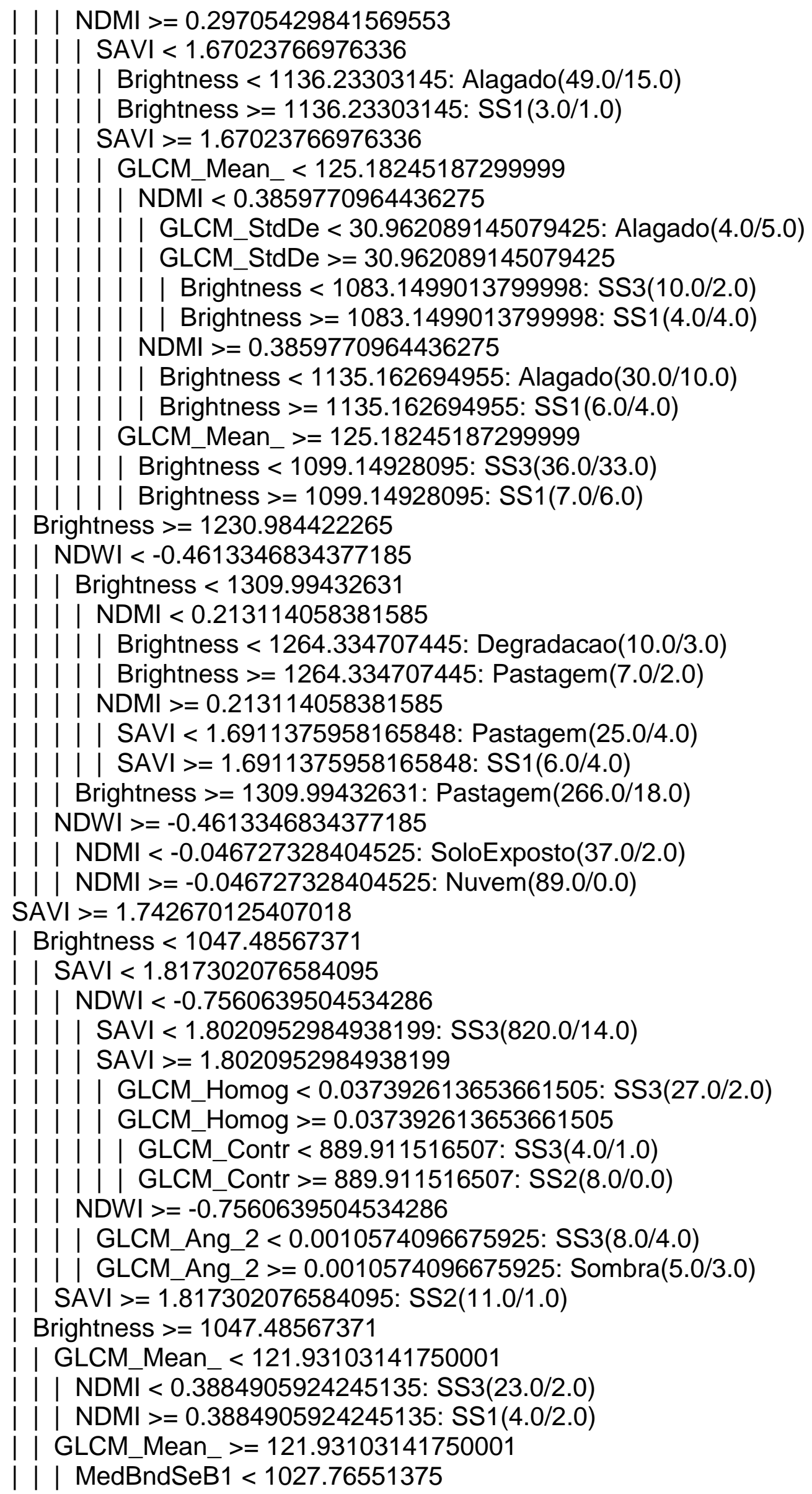




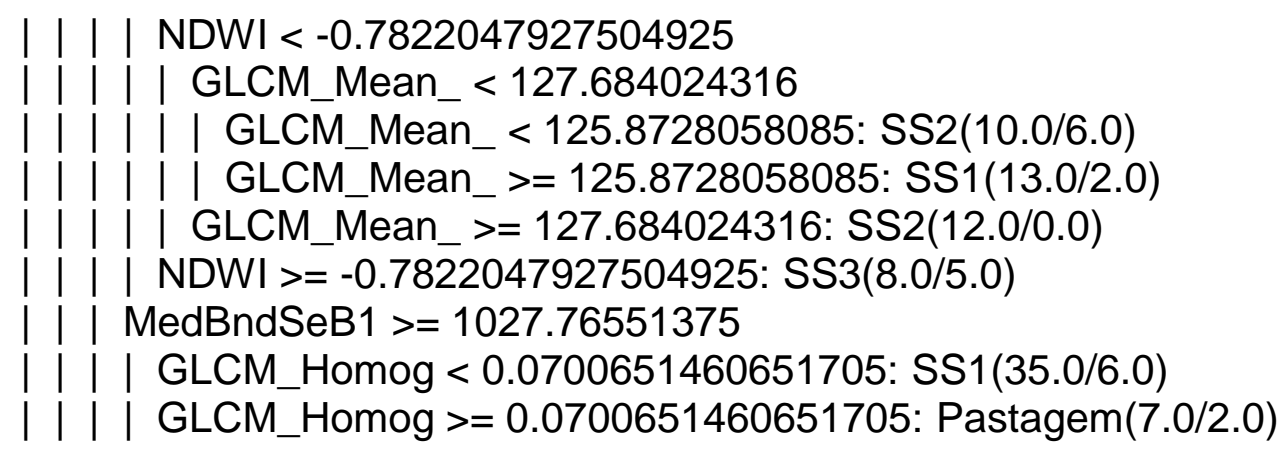

\section{CLASSIFICAÇÃO DE 2016}

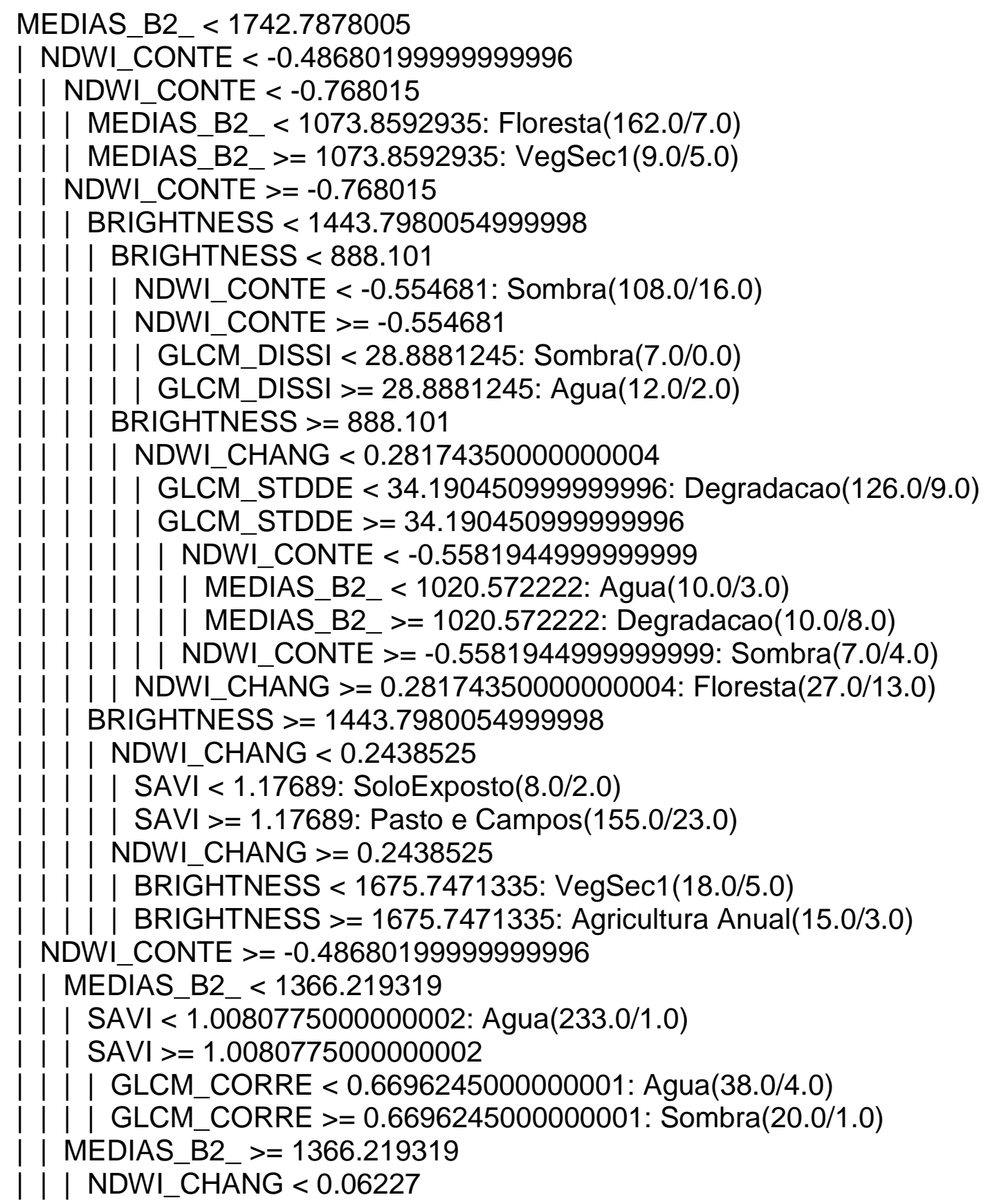


| | | | GLCM_ANG_2 < 0.0014605: SoloExposto(7.0/0.0)

1 | | GLCM_ANG_2 > 0.0014605: Agua(6.0/2.0)

1 | NDWI_CHANG >= 0.06227: Nuvem(18.0/0.0)

MEDIAS_B 2

| NDWI_CHĀNG <- 0.0032370000000000003

| $\mathrm{SAVI}<1.132862$ : SoloExposto(147.0/5.0)

SAVI >= 1.132862: Pasto e Campos(16.0/2.0)

| NDWI_CHANG $>=-0.0032370000000000003$

I | SAVI < 1.1841265: Nuvem(407.0/2.0)

| | SAVI >=1.1841265: Pasto e Campos(16.0/6.0) 


\section{APÊNDICE 2. SUMÁRIO DOS RESULTADOS DAS CLASSIFICAÇÕES REALIZADAS NO WEKA}

\section{CLASSIFICAÇÃO DE 1984}

Number of Leaf Nodes: 45

Size of the Tree: 89

Time taken to build model: 0.61 seconds

$===$ Evaluation on training set $===$

Time taken to test model on training data: 0.01 seconds

$===$ Summary $===$

$\begin{array}{lcc}\text { Correctly Classified Instances } & 1372 & 96.8243 \% \\ \text { Incorrectly Classified Instances } & 45 & 3.1757 \% \\ \text { Kappa statistic } & 0.9594 & \\ \text { Mean absolute error } & 0.01 & \\ \text { Root mean squared error } & 0.0708 & \\ \text { Relative absolute error } & 7.0272 \% & \\ \text { Root relative squared error } & 26.5251 \% & \\ \text { Total Number of Instances } & 1417 & \end{array}$

$===$ Detailed Accuracy By Class $===$

TP Rate FP Rate Precision Recall F-Measure MCC ROC Area PRC Area Class

$\begin{array}{lllllllll}0.833 & 0.000 & 1.000 & 0.833 & 0.909 & 0.913 & 0.997 & 0.850 & \text { Solo exposto } \\ 0.914 & 0.002 & 0.946 & 0.914 & 0.930 & 0.927 & 0.998 & 0.952 & \text { Alagado } \\ 0.957 & 0.006 & 0.944 & 0.957 & 0.951 & 0.945 & 0.996 & 0.958 & \text { Sombra } \\ 0.950 & 0.003 & 0.934 & 0.950 & 0.942 & 0.940 & 0.998 & 0.929 & \text { Agua } \\ 0.966 & 0.000 & 1.000 & 0.966 & 0.982 & 0.982 & 1.000 & 0.996 & \text { Degradacao } \\ 0.989 & 0.003 & 0.957 & 0.989 & 0.973 & 0.971 & 0.999 & 0.985 & \text { Pasto e campos } \\ 0.967 & 0.011 & 0.961 & 0.967 & 0.964 & 0.954 & 0.995 & 0.971 & \text { Floresta (SS3) } \\ 0.991 & 0.007 & 0.989 & 0.991 & 0.990 & 0.984 & 1.000 & 0.999 & \text { Nuvem } \\ 0.987 & 0.004 & 0.937 & 0.987 & 0.961 & 0.959 & 0.998 & 0.963 & \text { SS1 } \\ 0.889 & 0.002 & 0.960 & 0.889 & 0.923 & 0.919 & 0.992 & 0.939 & \text { SS2 } \\ 0.000 & 0.000 & 0.000 & 0.000 & 0.000 & 0.000 & 0.989 & 0.118 & \text { Agricultura anual } \\ 0.968 & 0.006 & 0.967 & 0.968 & 0.967 & 0.962 & 0.998 & 0.976 & \end{array}$

$\begin{array}{lllllllll}\text { W. Avg. } & 0.968 & 0.006 & 0.967 & 0.968 & 0.967 & 0.962 & 0.998 & 0.976\end{array}$

$===$ Confusion Matrix $===$

$a \quad b \quad c \quad d \quad e \quad f \quad g \quad h$ i j $k$ <-- classified as

\begin{tabular}{lllllllllll|l}
5 & 0 & 0 & 0 & 0 & 1 & 0 & 0 & 0 & 0 & 0 & $a=$ Solo exposto
\end{tabular}

\begin{tabular}{lllllllllll|l}
0 & 53 & 3 & 1 & 0 & 0 & 0 & 1 & 0 & 0 & 0 & $\mathrm{~b}=$ Alagado
\end{tabular}

\begin{tabular}{lllllllllll|l}
0 & 1 & 135 & 3 & 0 & 0 & 2 & 0 & 0 & 0 & 0 & $\mathrm{c}=$ Sombra
\end{tabular}

\begin{tabular}{lllllllllll|l}
0 & 0 & 3 & 57 & 0 & 0 & 0 & 0 & 0 & 0 & 0 & $\mathrm{~d}=$ Agua
\end{tabular}

\begin{tabular}{lllllllllll|l}
0 & 0 & 0 & 0 & 56 & 1 & 0 & 0 & 0 & 1 & 0 & $e=$ Degradacao
\end{tabular}

\begin{tabular}{lllllllllll|l}
0 & 1 & 0 & 0 & 0 & 90 & 0 & 0 & 0 & 0 & 0 & $\mathrm{f}=$ Pasto e campos
\end{tabular}

\begin{tabular}{lllllllllll|l}
0 & 0 & 2 & 0 & 0 & 1295 & 5 & 0 & 2 & 0 & $\mathrm{~g}=$ Floresta (SS3)
\end{tabular}

\begin{tabular}{lllllllllll|l}
0 & 1 & 0 & 0 & 0 & 0 & 4535 & 0 & 0 & 0 & $\mathrm{~h}=$ Nuvem
\end{tabular}

\begin{tabular}{lllllllllll|l}
0 & 0 & 0 & 0 & 0 & 0 & 1 & 0 & 74 & 0 & 0 & $\mathrm{i}=\mathrm{SS} 1$
\end{tabular}

\begin{tabular}{lllllllllll|l}
0 & 0 & 0 & 0 & 0 & 1 & 5 & 0 & 3 & 72 & 0 & $\mathrm{j}=\mathrm{SS} 2$
\end{tabular}

\begin{tabular}{lllllllllll|l}
0 & 0 & 0 & 0 & 0 & 0 & 0 & 0 & 2 & 0 & 0 & $\mathrm{k}=$ Agricultura anual
\end{tabular} 


\section{CLASSIFICAÇÃO DE 1986}

Number of Leaf Nodes: 30

Size of the Tree: 59

Time taken to build model: 0.87 seconds

$===$ Evaluation on training set $===$

Time taken to test model on training data: 0 seconds

$===$ Summary $===$

$\begin{array}{lcc}\text { Correctly Classified Instances } & 1633 & 92.9954 \% \\ \text { Incorrectly Classified Instances } & 123 & 7.0046 \% \\ \text { Kappa statistic } & 0.915 & \\ \text { Mean absolute error } & 0.0219 & \\ \text { Root mean squared error } & 0.1046 & \\ \text { Relative absolute error } & 14.5482 \% & \\ \text { Root relative squared error } & 38.1538 \% & \\ \text { Total Number of Instances } & 1756 & \end{array}$

$===$ Detailed Accuracy By Class $===$

\begin{tabular}{ccccccccll}
\multicolumn{2}{l}{ TP Rate FP Rate Precision Recall F-Measure } & MCC & \multicolumn{2}{l}{ ROC Area PRC Area Class } \\
0.862 & 0.002 & 0.962 & 0.862 & 0.909 & 0.906 & 0.995 & 0.917 & Solo exposto \\
0.951 & 0.014 & 0.855 & 0.951 & 0.901 & 0.893 & 0.992 & 0.883 & Pasto e campos \\
0.877 & 0.014 & 0.860 & 0.877 & 0.868 & 0.855 & 0.974 & 0.852 & Alagado \\
0.902 & 0.003 & 0.974 & 0.902 & 0.937 & 0.931 & 0.992 & 0.939 & Agua \\
0.989 & 0.015 & 0.967 & 0.989 & 0.977 & 0.968 & 0.998 & 0.992 & Nuvem \\
0.918 & 0.005 & 0.927 & 0.918 & 0.922 & 0.917 & 0.991 & 0.909 & Sombra \\
0.936 & 0.023 & 0.922 & 0.936 & 0.929 & 0.908 & 0.986 & 0.922 & Floresta (SS3) \\
0.931 & 0.002 & 0.957 & 0.931 & 0.944 & 0.941 & 0.998 & 0.941 & SS1 \\
0.500 & 0.000 & 1.000 & 0.500 & 0.667 & 0.706 & 0.946 & 0.518 & Degradacao \\
0.802 & 0.007 & 0.875 & 0.802 & 0.837 & 0.829 & 0.977 & 0.816 & SS2 \\
1.000 & 0.000 & 1.000 & 1.000 & 1.000 & 1.000 & 1.000 & 1.000 & Agricultura anual \\
W. Avg. & 0.930 & 0.013 & 0.931 & 0.930 & 0.929 & 0.919 & 0.990 & 0.927 &
\end{tabular}

$===$ Confusion Matrix $===$

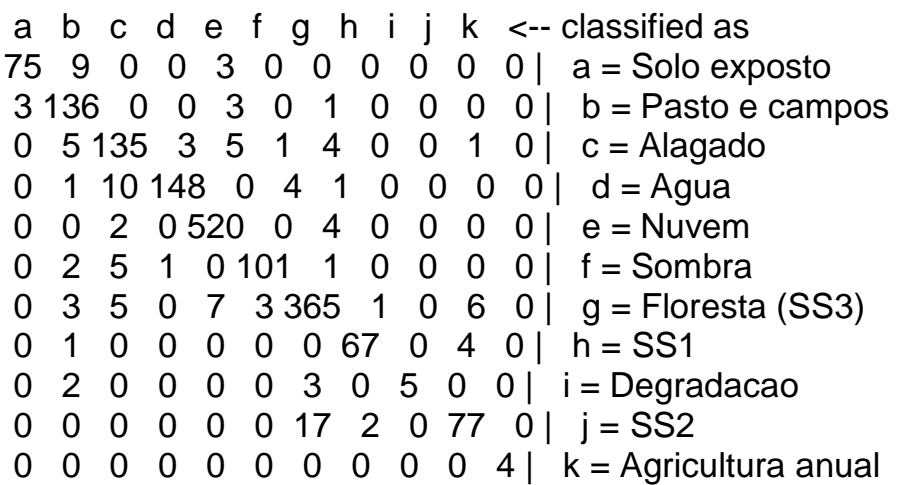




\section{CLASSIFICAÇÃO DE 1988}

Number of Leaf Nodes: 34

Size of the Tree: 67

Time taken to build model: 0.24 seconds

$===$ Evaluation on training set $===$

Time taken to test model on training data: 0.01 seconds

$===$ Summary $===$

$\begin{array}{lcc}\text { Correctly Classified Instances } & 585 & 95.2769 \% \\ \text { Incorrectly Classified Instances } & 29 & 4.7231 \% \\ \text { Kappa statistic } & 0.947 & \\ \text { Mean absolute error } & 0.0155 & \\ \text { Root mean squared error } & 0.088 & \\ \text { Relative absolute error } & 9.5648 \% & \\ \text { Root relative squared error } & 30.9326 \% & \\ \text { Total Number of Instances } & 614 & \end{array}$

$===$ Detailed Accuracy By Class $===$

\begin{tabular}{clllllllll}
\multicolumn{1}{l}{ TP Rate FP Rate Precision Recall } & F-Measure & MCC & \multicolumn{2}{l}{ ROC Area PRC Area Class } \\
0.870 & 0.000 & 1.000 & 0.870 & 0.930 & 0.928 & 0.991 & 0.937 & Solo exposto \\
0.902 & 0.003 & 0.949 & 0.902 & 0.925 & 0.920 & 0.990 & 0.903 & Alagado \\
0.955 & 0.005 & 0.933 & 0.955 & 0.944 & 0.939 & 0.996 & 0.923 & Agua \\
0.970 & 0.000 & 1.000 & 0.970 & 0.985 & 0.982 & 0.998 & 0.992 & Floresta (SS3) \\
0.976 & 0.005 & 0.930 & 0.976 & 0.952 & 0.949 & 0.998 & 0.955 & Sombra \\
0.961 & 0.013 & 0.913 & 0.961 & 0.936 & 0.927 & 0.993 & 0.912 & Pasto e campos \\
0.982 & 0.007 & 0.933 & 0.982 & 0.957 & 0.953 & 0.996 & 0.938 & Nuvem \\
0.969 & 0.003 & 0.939 & 0.969 & 0.954 & 0.951 & 0.998 & 0.947 & Degradacao \\
0.963 & 0.007 & 0.951 & 0.963 & 0.957 & 0.950 & 0.997 & 0.959 & SS1 \\
& 0.964 & 0.002 & 0.988 & 0.964 & 0.976 & 0.972 & 0.997 & 0.977 & SS2 \\
& 0.833 & 0.005 & 0.769 & 0.833 & 0.800 & 0.797 & 0.980 & 0.680 & Agricultura anual \\
W. Avg. & 0.953 & 0.005 & 0.954 & 0.953 & 0.953 & 0.948 & 0.995 & 0.945 &
\end{tabular}

$===$ Confusion Matrix $===$

$\mathrm{a} \mathrm{b} \mathrm{c} \mathrm{d} \mathrm{e} \mathrm{f} \mathrm{g} \mathrm{h} \mathrm{i} \mathrm{j} \mathrm{k} \mathrm{<--} \mathrm{classified} \mathrm{as}$

\begin{tabular}{lllllllllll|l}
40 & 0 & 0 & 0 & 0 & 4 & 2 & 0 & 0 & 0 & 0 & $\mathrm{a}=$ Solo exposto
\end{tabular}

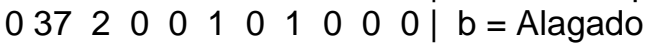

\begin{tabular}{lllllllllll|l}
0 & 1 & 42 & 0 & 0 & 0 & 0 & 1 & 0 & 0 & 0 & $\mathrm{c}=$ Agua
\end{tabular}

\begin{tabular}{lllllllllll|l}
0 & 0 & 0 & 98 & 2 & 0 & 0 & 0 & 0 & 1 & 0 & $\mathrm{~d}=$ = Floresta (SS3)
\end{tabular}

\begin{tabular}{lllllllllll|l}
0 & 0 & 1 & 0 & 40 & 0 & 0 & 0 & 0 & 0 & 0 & $\mathrm{e}=$ Sombra
\end{tabular}

\begin{tabular}{lllllllllll|l}
0 & 0 & 0 & 0 & 0 & 73 & 2 & 0 & 0 & 0 & 1 & $\mathrm{f}=$ Pasto e campos
\end{tabular}

\begin{tabular}{lllllllllll|l}
0 & 0 & 0 & 0 & 0 & 156 & 0 & 0 & 0 & 0 & $\mathrm{~g}=$ Nuvem
\end{tabular}

\begin{tabular}{lllllllllll|l}
0 & 1 & 0 & 0 & 0 & 0 & 0 & 31 & 0 & 0 & 0 & $\mathrm{~h}=$ Degradacao
\end{tabular}

\begin{tabular}{lllllllllll|l}
0 & 0 & 0 & 0 & 1 & 0 & 0 & 0 & 77 & 0 & 2 & $\mathrm{i}=\mathrm{SS} 1$
\end{tabular}

\begin{tabular}{lllllllllll|l}
0 & 0 & 0 & 0 & 0 & 0 & 0 & 0 & 3 & 81 & 0 & $\mathrm{j}=\mathrm{SS} 2$
\end{tabular}

$\begin{array}{llllllllllllll}0 & 0 & 0 & 0 & 0 & 1 & 0 & 0 & 1 & 0 & 10 & k=\text { Agricultura anual }\end{array}$ 


\section{CLASSIFICAÇÃO DE 1991}

Number of Leaf Nodes: 129

Size of the Tree: 257

Time taken to build model: 1.33 seconds

$===$ Evaluation on training set $===$

Time taken to test model on training data: 0.01 seconds

$===$ Summary $===$

$\begin{array}{lcc}\text { Correctly Classified Instances } & 2592 & 97.006 \% \\ \text { Incorrectly Classified Instances } & 80 & 2.994 \% \\ \text { Kappa statistic } & 0.9633 & \\ \text { Mean absolute error } & 0.0101 & \\ \text { Root mean squared error } & 0.071 & \\ \text { Relative absolute error } & 6.176 \% & \\ \text { Root relative squared error } & 24.8562 \% & \\ \text { Total Number of Instances } & 2672 & \end{array}$

$===$ Detailed Accuracy By Class $===$

\begin{tabular}{|c|c|c|c|c|c|c|c|c|}
\hline P Rat & FP F & $\operatorname{Pre}$ & in & & & $\mathrm{MCO}$ & ROC Are & PRC Area $\mathrm{C}$ \\
\hline 0.933 & 0.005 & 0.914 & 0.933 & 0.924 & 0.919 & 0.998 & 0.962 & Alagado \\
\hline 0.932 & 0.004 & 0.949 & 0.932 & 0.940 & 0.935 & 0.998 & 0.968 & Agua \\
\hline 0.975 & 0.010 & 0.947 & 0.975 & 0.961 & 0.954 & 0.997 & 0.974 & Sombra \\
\hline 0.963 & 0.000 & 0.981 & 0.963 & 0.972 & 0.971 & 1.000 & 0.981 & Solo exposto \\
\hline 0.999 & 0.003 & 0.993 & 0.999 & 0.996 & 0.994 & 0.999 & 0.996 & Nuvem \\
\hline 0.942 & 0.003 & 0.942 & 0.942 & 0.942 & 0.939 & 0.996 & 0.951 & Pasto e campos \\
\hline 0.972 & 0.004 & 0.987 & 0.972 & 0.979 & 0.973 & 0.998 & 0.991 & Floresta (SS3) \\
\hline 0.964 & 0.003 & 0.953 & 0.964 & 0.958 & 0.956 & 0.998 & 0.976 & SS2 \\
\hline 929 & 0.001 & 0.975 & 0.929 & 0.952 & 0.950 & 0.998 & 0.974 & SS1 \\
\hline 0.000 & 0.000 & 0.000 & 0.000 & 0.000 & 0.000 & 0.990 & 0.176 & Degradacao \\
\hline 970 & 0.004 & 0.970 & 0.970 & 0.970 & 0.966 & 0.998 & 0.982 & \\
\hline
\end{tabular}

$\begin{array}{lllllllll}\text { W. Avg. } & 0.970 & 0.004 & 0.970 & 0.970 & 0.970 & 0.966 & 0.998 & 0.982\end{array}$

$===$ Confusion Matrix $===$

a $b$ c d e f $g$ h i j <-- classified as

\begin{tabular}{llllllllll|l}
139 & 5 & 5 & 0 & 0 & 0 & 0 & 0 & 0 & 0 & $\mathrm{a}=$ Alagado
\end{tabular}

\begin{tabular}{llllllllll|l}
10 & 205 & 2 & 0 & 0 & 1 & 2 & 0 & 0 & 0 & $\mathrm{~b}=$ Agua
\end{tabular}

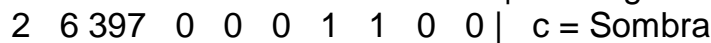

$\begin{array}{llllllllllll}0 & 0 & 1 & 52 & 1 & 0 & 0 & 0 & 0 & 0 & \mathrm{~d}=\text { Solo exposto }\end{array}$

\begin{tabular}{llllllllll|l}
0 & 0 & 0 & 0 & 804 & 1 & 0 & 0 & 0 & 0 & $\mathrm{e}=$ Nuvem
\end{tabular}

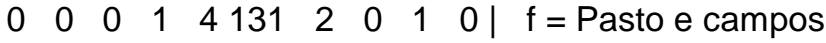

\begin{tabular}{llllllllll|l}
0 & 0 & 13 & 0 & 0 & 1585 & 3 & 0 & 0 & $\mathrm{~g}=$ Floresta (SS3)
\end{tabular}

\begin{tabular}{llllllllll|l}
0 & 0 & 1 & 0 & 0 & 0 & 3 & 161 & 2 & 0 & $\mathrm{~h}=\mathrm{SS} 2$
\end{tabular}

\begin{tabular}{llllllllll|l}
0 & 0 & 0 & 0 & 1 & 4 & 0 & 4118 & 0 & $\mathrm{i}=\mathrm{SS} 1$
\end{tabular}

\begin{tabular}{llllllllll|l}
1 & 0 & 0 & 0 & 0 & 1 & 0 & 0 & 0 & 0 & $j$ \\
$j$ & $=$ Degradacao
\end{tabular} 


\section{CLASSIFICAÇÃO DE 1995}

Number of Leaf Nodes: 77

Size of the Tree: 153

Time taken to build model: 1.47 seconds

$===$ Evaluation on training set $===$

Time taken to test model on training data: 0.01 seconds

$===$ Summary $===$

Correctly Classified Instances $\quad 3043 \quad 94.8566 \%$

Incorrectly Classified Instances $165 \quad 5.1434 \%$

Kappa statistic $\quad 0.9346$

Mean absolute error $\quad 0.0179$

Root mean squared error $\quad 0.0947$

Relative absolute error $\quad 11.3653 \%$

Root relative squared error $\quad 33.7198 \%$

Total Number of Instances $\quad 3208$

$===$ Detailed Accuracy By Class $===$

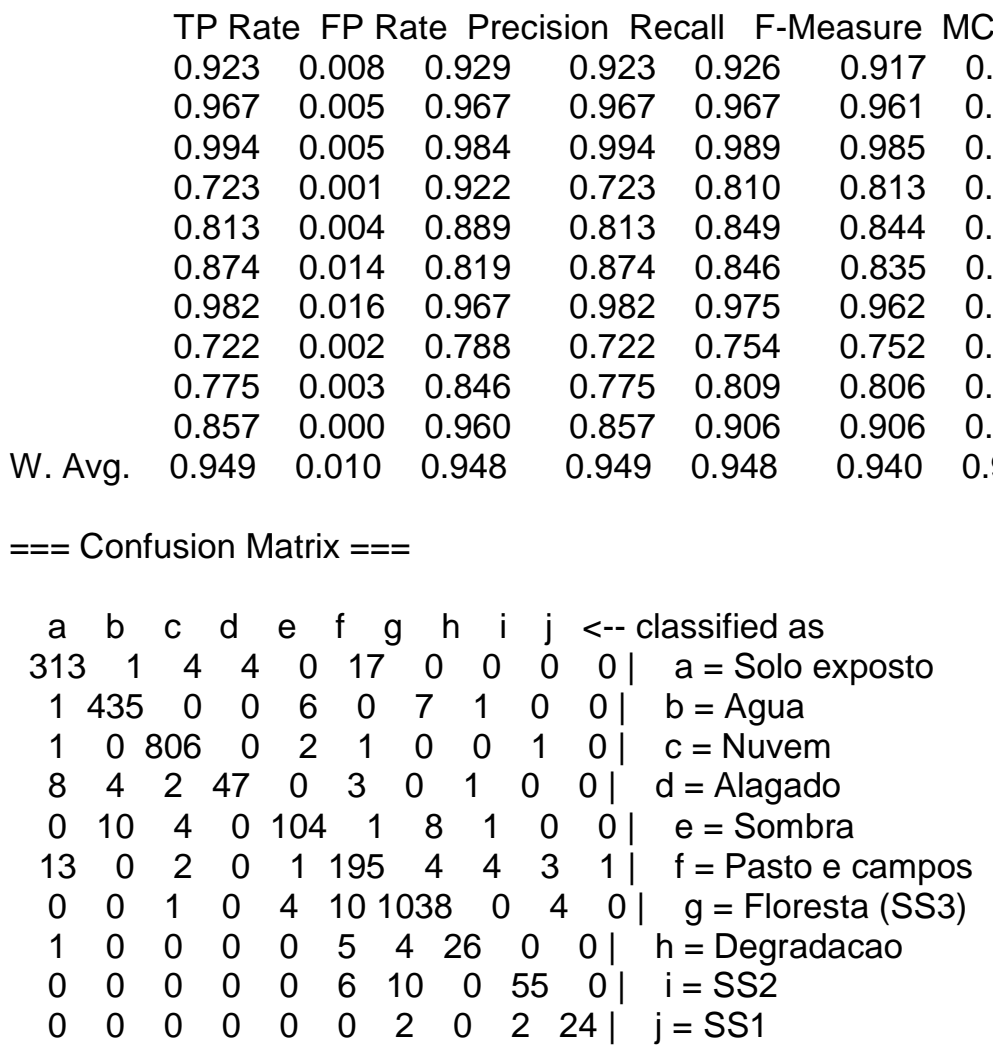

ROC Area PRC Area Class

0.963 Solo exposto

0.981 Agua

0.997 Nuvem

0.830 Alagado

0.833 Sombra

0.828 Pasto e campos

0.975 Floresta (SS3)

$\begin{array}{lllllllll}0.722 & 0.002 & 0.788 & 0.722 & 0.754 & 0.752 & 0.977 & 0.735 & \text { Degradacao }\end{array}$

$\begin{array}{lllllllll}0.775 & 0.003 & 0.846 & 0.775 & 0.809 & 0.806 & 0.977 & 0.760 & \text { SS2 }\end{array}$

$\begin{array}{lllllllll}0.857 & 0.000 & 0.960 & 0.857 & 0.906 & 0.906 & 0.999 & 0.917 & \text { SS1 }\end{array}$

$===$ Confusion Matrix $===$

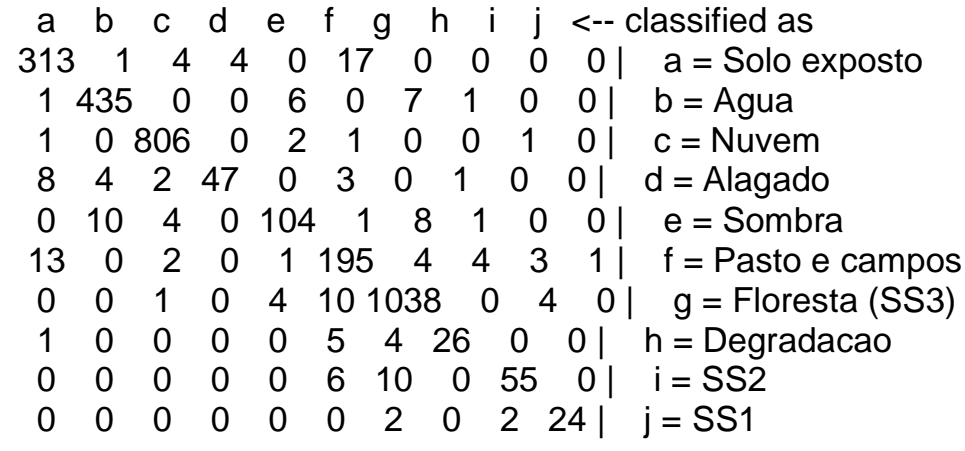




\section{CLASSIFICAÇÃO DE 1997}

Number of Leaf Nodes: 44

Size of the Tree: 87

Time taken to build model: 0.84 seconds

$===$ Evaluation on training set $===$

Time taken to test model on training data: 0.01 seconds

$===$ Summary $===$

$\begin{array}{lcc}\text { Correctly Classified Instances } & 1542 & 90.8127 \% \\ \text { Incorrectly Classified Instances } & 156 & 9.1873 \% \\ \text { Kappa statistic } & 0.892 & \\ \text { Mean absolute error } & 0.0281 & \\ \text { Root mean squared error } & 0.1186 & \\ \text { Relative absolute error } & 18.1244 \% & \\ \text { Root relative squared error } & 42.5816 \% & \\ \text { Total Number of Instances } & 1698 & \end{array}$

$===$ Detailed Accuracy By Class $===$

\begin{tabular}{|c|c|c|c|c|c|c|c|c|}
\hline Rate & FP & $\mathrm{Pr}_{\mathrm{r}}$ & & & & $\mathrm{MCC}$ & BOC Are & Are? \\
\hline 0.875 & 0.009 & 0.858 & 0.875 & 0.867 & 0.858 & 0.987 & 0.839 & SS2 \\
\hline 0.912 & 0.013 & 0.861 & 0.912 & 0.886 & 0.876 & 0.993 & 0.900 & SS1 \\
\hline 0.896 & 0.009 & 0.917 & 0.896 & 0.906 & 0.896 & 0.990 & 0.926 & Solo exposto \\
\hline 0.957 & 0.035 & 0.886 & 0.957 & 0.920 & 0.898 & 0.988 & 0.930 & Agua \\
\hline 0.638 & 0.002 & 0.917 & 0.638 & 0.752 & 0.757 & 0.957 & 0.737 & Sombra \\
\hline 0.916 & 0.017 & 0.897 & 0.916 & 0.906 & 0.891 & 0.987 & 0.902 & Pasto e campos \\
\hline 0.979 & 0.000 & 1.000 & 0.979 & 0.989 & 0.988 & 0.999 & 0.994 & Nuvem \\
\hline .643 & 0.007 & 0.766 & 0.643 & 0.699 & 0.693 & 0.974 & 0.653 & Alagado \\
\hline 949 & 0.011 & 0.962 & 0.949 & 0.955 & 0.943 & 0.994 & 0.971 & Floresta (SS3) \\
\hline 0.688 & 0.003 & 0.815 & 0.688 & 0.746 & 0.744 & 0.985 & 0.719 & Degradacao \\
\hline 1.000 & 0.001 & 0.750 & 1.000 & 0.857 & 0.866 & 0.999 & 0.750 & Agricultura anual \\
\hline & & & & & & & & \\
\hline
\end{tabular}

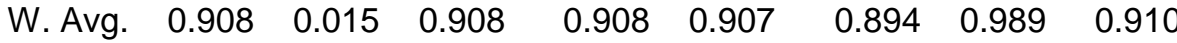

$===$ Confusion Matrix $===$

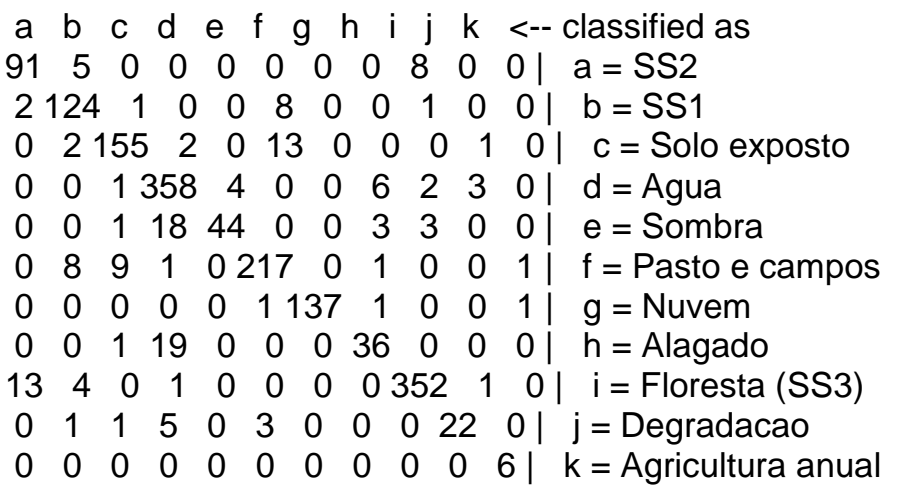




\section{CLASSIFICAÇÃO DE 1999}

Number of Leaf Nodes: 52

Size of the Tree: 103

Time taken to build model: 1.18 seconds

$===$ Evaluation on training set $===$

Time taken to test model on training data: 0.01 seconds

$===$ Summary $===$

$\begin{array}{lcc}\text { Correctly Classified Instances } & 2273 & 92.5866 \% \\ \text { Incorrectly Classified Instances } & 182 & 7.4134 \% \\ \text { Kappa statistic } & 0.9061 & \\ \text { Mean absolute error } & 0.0224 & \\ \text { Root mean squared error } & 0.1058 & \\ \text { Relative absolute error } & 15.5327 \% & \\ \text { Root relative squared error } & 39.4244 \% & \\ \text { Total Number of Instances } & 2455 & \end{array}$

$===$ Detailed Accuracy By Class ===

\begin{tabular}{|c|c|c|c|c|c|c|c|c|}
\hline \multicolumn{6}{|c|}{ TP Rate FP Rate Precision Recall } & MCC & \multicolumn{2}{|c|}{ ROC Area PRC Area Class } \\
\hline 0.611 & 0.002 & 0.846 & 0.611 & 0.710 & 0.716 & 0.985 & 0.661 & Sombra \\
\hline 0.922 & 0.010 & 0.943 & 0.922 & 0.932 & 0.921 & 0.994 & 0.961 & Solo exposto \\
\hline 0.935 & 0.017 & 0.884 & 0.935 & 0.909 & 0.896 & 0.994 & 0.938 & Agua \\
\hline 0.704 & 0.009 & 0.767 & 0.704 & 0.734 & 0.724 & 0.983 & 0.689 & Alagado \\
\hline 0.875 & 0.002 & 0.840 & 0.875 & 0.857 & 0.856 & 0.999 & 0.890 & Degradacao \\
\hline 0.949 & 0.001 & 0.982 & 0.949 & 0.966 & 0.963 & 0.996 & 0.965 & Nuvem \\
\hline 0.903 & 0.017 & 0.867 & 0.903 & 0.885 & 0.871 & 0.989 & 0.888 & Pasto e campos \\
\hline 0.990 & 0.019 & 0.971 & 0.990 & 0.981 & 0.968 & 0.997 & 0.993 & Floresta (SS3) \\
\hline 0.746 & 0.004 & 0.833 & 0.746 & 0.787 & 0.783 & 0.983 & 0.737 & Agricultura anual \\
\hline 0.947 & 0.006 & 0.894 & 0.947 & 0.920 & 0.915 & 0.996 & 0.912 & SS1 \\
\hline 0.618 & 0.002 & 0.895 & 0.618 & 0.731 & 0.739 & 0.975 & 0.732 & SS2 \\
\hline 0.926 & 0.013 & 0.925 & 0.926 & 0.924 & 0.914 & 0.994 & 0.933 & \\
\hline
\end{tabular}

$===$ Confusion Matrix $===$

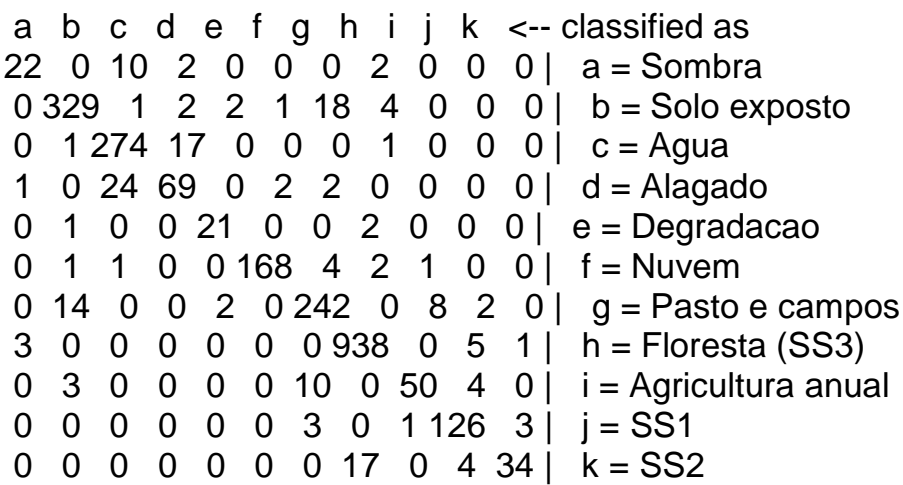




\section{CLASSIFICAÇÃO DE 2001}

Number of Leaf Nodes: 36

Size of the Tree: 71

Time taken to build model: 0.96 seconds

$===$ Evaluation on training set $===$

Time taken to test model on training data: 0.01 seconds

$===$ Summary $===$

$\begin{array}{lcc}\text { Correctly Classified Instances } & 2391 & 96.4502 \% \\ \text { Incorrectly Classified Instances } & 88 & 3.5498 \% \\ \text { Kappa statistic } & 0.9527 & \\ \text { Mean absolute error } & 0.0123 & \\ \text { Root mean squared error } & 0.0784 & \\ \text { Relative absolute error } & 8.1966 \% & \\ \text { Root relative squared error } & 28.6411 \% & \\ \text { Total Number of Instances } & 2479 & \end{array}$

$===$ Detailed Accuracy By Class $===$

TP Rate FP Rate Precision Recall F-Measure MCC ROC Area PRC Area Class

$\begin{array}{lllllllll}0.988 & 0.001 & 0.999 & 0.988 & 0.993 & 0.989 & 0.999 & 0.999 & \text { Nuvem } \\ 0.633 & 0.002 & 0.884 & 0.633 & 0.738 & 0.743 & 0.982 & 0.728 & \text { Alagado } \\ 0.933 & 0.004 & 0.960 & 0.933 & 0.946 & 0.942 & 0.997 & 0.950 & \text { Solo exposto } \\ 0.978 & 0.009 & 0.900 & 0.978 & 0.938 & 0.934 & 0.996 & 0.911 & \text { Pasto e campos } \\ 0.931 & 0.002 & 0.900 & 0.931 & 0.915 & 0.913 & 0.993 & 0.865 & \text { SS2 } \\ 0.982 & 0.016 & 0.904 & 0.982 & 0.941 & 0.933 & 0.997 & 0.965 & \text { Agua } \\ 0.860 & 0.002 & 0.941 & 0.860 & 0.899 & 0.896 & 0.995 & 0.921 & \text { Sombra } \\ 0.995 & 0.002 & 0.989 & 0.995 & 0.992 & 0.990 & 0.999 & 0.991 & \text { Floresta (SS3) } \\ 0.840 & 0.000 & 1.000 & 0.840 & 0.913 & 0.916 & 0.999 & 0.914 & \text { SS1 } \\ 0.538 & 0.002 & 0.636 & 0.538 & 0.583 & 0.583 & 0.985 & 0.411 & \text { Degradacao } \\ 0.965 & 0.004 & 0.965 & 0.965 & 0.964 & 0.959 & 0.998 & 0.966 & \end{array}$

$===$ Confusion Matrix $===$

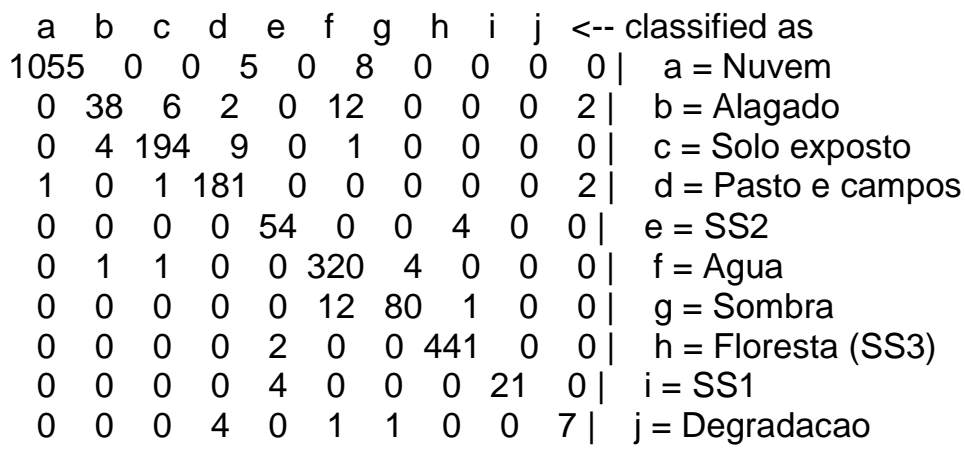




\section{CLASSIFICAÇÃO DE 2004}

Number of Leaf Nodes: 47

Size of the Tree: 93

Time taken to build model: 0.96 seconds

$===$ Evaluation on training set $===$

Time taken to test model on training data: 0.01 seconds

$===$ Summary $===$

$\begin{array}{lcc}\text { Correctly Classified Instances } & 1598 & 91.681 \% \\ \text { Incorrectly Classified Instances } & 145 & 8.319 \% \\ \text { Kappa statistic } & 0.8999 & \\ \text { Mean absolute error } & 0.0257 & \\ \text { Root mean squared error } & 0.1133 & \\ \text { Relative absolute error } & 16.9332 \% & \\ \text { Root relative squared error } & 41.1615 \% & \\ \text { Total Number of Instances } & 1743 & \end{array}$

$===$ Detailed Accuracy By Class $===$

\begin{tabular}{lllllllll}
\multicolumn{1}{l}{ TP Rate FP Rate Precision Recall } & F-Measure & MCC & \multicolumn{2}{c}{ ROC Area PRC Area Class } \\
0.955 & 0.026 & 0.915 & 0.955 & 0.934 & 0.915 & 0.994 & 0.976 & Agua \\
0.750 & 0.007 & 0.880 & 0.750 & 0.810 & 0.801 & 0.982 & 0.827 & Sombra \\
0.800 & 0.007 & 0.842 & 0.800 & 0.821 & 0.812 & 0.986 & 0.813 & Alagado \\
0.909 & 0.005 & 0.963 & 0.909 & 0.935 & 0.927 & 0.991 & 0.939 & Solo exposto \\
0.929 & 0.023 & 0.857 & 0.929 & 0.892 & 0.876 & 0.985 & 0.874 & Pasto e campos \\
0.849 & 0.008 & 0.776 & 0.849 & 0.811 & 0.805 & 0.982 & 0.707 & SS2 \\
0.952 & 0.002 & 0.968 & 0.952 & 0.960 & 0.957 & 0.995 & 0.949 & Nuvem \\
0.974 & 0.014 & 0.962 & 0.974 & 0.968 & 0.956 & 0.994 & 0.971 & Floresta (SS3) \\
0.429 & 0.000 & 1.000 & 0.429 & 0.600 & 0.653 & 0.983 & 0.550 & Degradacao \\
0.629 & 0.003 & 0.815 & 0.629 & 0.710 & 0.711 & 0.978 & 0.633 & SS1 \\
0.925 & 0.003 & 0.881 & 0.925 & 0.902 & 0.900 & 0.998 & 0.881 & Agricultura anual \\
0.917 & 0.014 & 0.918 & 0.917 & 0.915 & 0.904 & 0.991 & 0.918 &
\end{tabular}

$\begin{array}{lllllllll}\text { W. Avg. } & 0.917 & 0.014 & 0.918 & 0.917 & 0.915 & 0.904 & 0.991 & 0.918\end{array}$

$===$ Confusion Matrix $===$

$a b c$ d e f g h i j $k$ <-- classified as

\begin{tabular}{lllllllllll|l}
378 & 8 & 8 & 0 & 0 & 0 & 0 & 1 & 0 & 1 & 0 & $a=$ Agua
\end{tabular}

\begin{tabular}{lllllllllll|l}
18 & 81 & 3 & 1 & 5 & 0 & 0 & 0 & 0 & 0 & 0 & $b=$ Sombra
\end{tabular}

\begin{tabular}{lllllllllll|l}
12 & 2 & 64 & 1 & 1 & 0 & 0 & 0 & 0 & 0 & 0 & $\mathrm{c}=$ Alagado
\end{tabular}

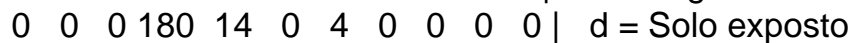

\begin{tabular}{llllllllll|l}
1 & 0 & 0 & 4210 & 4 & 0 & 5 & 0 & 0 & $2 \mid$ & e= $=$ Pasto e campos
\end{tabular}

\begin{tabular}{lllllllllll|l}
0 & 0 & 0 & 0 & 1 & 45 & 0 & 7 & 0 & 0 & 0 & $\mathrm{f}=\mathrm{SS} 2$
\end{tabular}

\begin{tabular}{lllllllllll|l}
0 & 0 & 0 & 1 & 3 & 0 & 120 & 1 & 0 & 0 & 1 & $\mathrm{~g}=$ Nuvem
\end{tabular}

\begin{tabular}{lllllllllll|l}
2 & 1 & 1 & 0 & 3 & 2 & 0 & 455 & 0 & 2 & $1 \mid$ & $\mathrm{h}=$ Floresta (SS3)
\end{tabular}

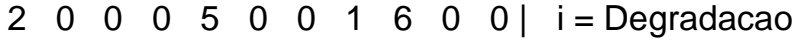

\begin{tabular}{lllllllllll|l}
0 & 0 & 0 & 0 & 3 & 6 & 0 & 3 & 0 & 22 & $1 \mid$ & $j=S S 1$
\end{tabular}

\begin{tabular}{lllllllllll|l}
0 & 0 & 0 & 0 & 0 & 1 & 0 & 0 & 0 & 2 & 37 & $\mathrm{k}=$ Agricultura anual
\end{tabular} 


\section{CLASSIFICAÇÃO DE 2005}

Number of Leaf Nodes: 43

Size of the Tree: 85

Time taken to build model: 1.22 seconds

$===$ Evaluation on training set $===$

Time taken to test model on training data: 0.02 seconds

$===$ Summary $===$

$\begin{array}{lcc}\text { Correctly Classified Instances } & 2129 & 92.2044 \% \\ \text { Incorrectly Classified Instances } & 180 & 7.7956 \% \\ \text { Kappa statistic } & 0.9085 & \\ \text { Mean absolute error } & 0.0245 & \\ \text { Root mean squared error } & 0.1107 & \\ \text { Relative absolute error } & 15.7761 \% & \\ \text { Root relative squared error } & 39.7252 \% & \\ \text { Total Number of Instances } & 2309 & \end{array}$

$===$ Detailed Accuracy By Class $===$

\begin{tabular}{llllllllll}
\multicolumn{1}{l}{ TP Rate FP Rate Precision Recall } & F-Measure \\
0.936 & 0.007 & 0.931 & 0.936 & 0.934 & 0.927 & 0.994 & \multicolumn{2}{l}{ ROC Area PRC Area Class } \\
0.794 & 0.001 & 0.962 & 0.794 & 0.870 & 0.870 & 0.991 & 0.855 & Nuvem \\
0.913 & 0.013 & 0.926 & 0.913 & 0.920 & 0.905 & 0.984 & 0.909 & Solo exposto \\
0.967 & 0.012 & 0.917 & 0.967 & 0.942 & 0.934 & 0.997 & 0.973 & Agua \\
0.985 & 0.006 & 0.980 & 0.985 & 0.983 & 0.977 & 0.998 & 0.987 & Floresta (SS3) \\
0.737 & 0.002 & 0.848 & 0.737 & 0.789 & 0.787 & 0.994 & 0.761 & Alagado \\
0.786 & 0.004 & 0.868 & 0.786 & 0.825 & 0.820 & 0.973 & 0.783 & SS2 \\
0.828 & 0.012 & 0.780 & 0.828 & 0.803 & 0.793 & 0.984 & 0.732 & SS1 \\
0.914 & 0.027 & 0.880 & 0.914 & 0.897 & 0.874 & 0.982 & 0.888 & Pasto e campos \\
0.902 & 0.004 & 0.951 & 0.902 & 0.926 & 0.920 & 0.991 & 0.915 & Agricultura anual \\
& 0.789 & 0.000 & 0.938 & 0.789 & 0.857 & 0.859 & 0.995 & 0.809 & Degradacao \\
W. Avg. & 0.922 & 0.011 & 0.923 & 0.922 & 0.922 & 0.912 & 0.990 & 0.918 &
\end{tabular}

$===$ Confusion Matrix $===$

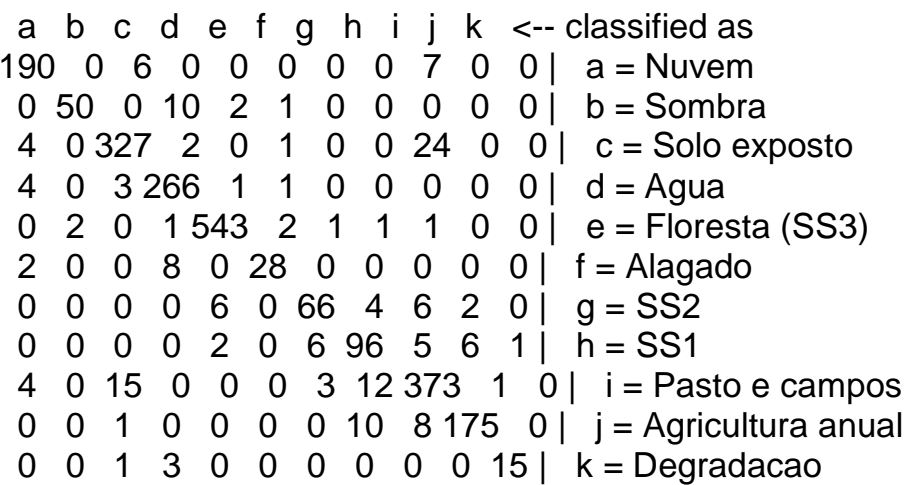




\section{CLASSIFICAÇÃO DE 2006}

Number of Leaf Nodes: 58

Size of the Tree: 115

Time taken to build model: 1.64 seconds

$===$ Evaluation on training set $===$

Time taken to test model on training data: 0.01 seconds

$===$ Summary $===$

$\begin{array}{lcc}\text { Correctly Classified Instances } & 3110 & 93.3654 \% \\ \text { Incorrectly Classified Instances } & 221 & 6.6346 \% \\ \text { Kappa statistic } & 0.9155 & \\ \text { Mean absolute error } & 0.0203 & \\ \text { Root mean squared error } & 0.1007 & \\ \text { Relative absolute error } & 14.1688 \% & \\ \text { Root relative squared error } & 37.651 \% & \\ \text { Total Number of Instances } & 3331 & \end{array}$

$===$ Detailed Accuracy By Class $===$

\begin{tabular}{llllllllll}
\multicolumn{1}{l}{ TP Rate FP Rate Precision Recall } & F-Measure & MCC & \multicolumn{2}{l}{ ROC Area PRC Area Class } \\
0.898 & 0.006 & 0.936 & 0.898 & 0.917 & 0.909 & 0.995 & 0.954 & Agua \\
0.887 & 0.012 & 0.861 & 0.887 & 0.874 & 0.863 & 0.987 & 0.887 & Sombra \\
0.905 & 0.001 & 0.971 & 0.905 & 0.937 & 0.935 & 0.993 & 0.943 & SoloNu \\
0.720 & 0.005 & 0.771 & 0.720 & 0.745 & 0.740 & 0.992 & 0.771 & Degradacao \\
0.921 & 0.014 & 0.834 & 0.921 & 0.876 & 0.867 & 0.994 & 0.883 & Pasto e campos \\
0.655 & 0.003 & 0.783 & 0.655 & 0.713 & 0.711 & 0.988 & 0.689 & Alagado \\
0.989 & 0.004 & 0.991 & 0.989 & 0.990 & 0.986 & 0.999 & 0.994 & Nuvem \\
0.974 & 0.024 & 0.950 & 0.974 & 0.961 & 0.943 & 0.991 & 0.969 & Floresta (SS3) \\
0.597 & 0.002 & 0.860 & 0.597 & 0.705 & 0.712 & 0.961 & 0.641 & SS2 \\
0.826 & 0.006 & 0.784 & 0.826 & 0.804 & 0.799 & 0.985 & 0.737 & SS1 \\
& 0.855 & 0.001 & 0.964 & 0.855 & 0.906 & 0.906 & 0.995 & 0.874 & Agricultura anual \\
W. Avg. & 0.934 & 0.012 & 0.934 & 0.934 & 0.933 & 0.923 & 0.993 & 0.938 &
\end{tabular}

$===$ Confusion Matrix $===$

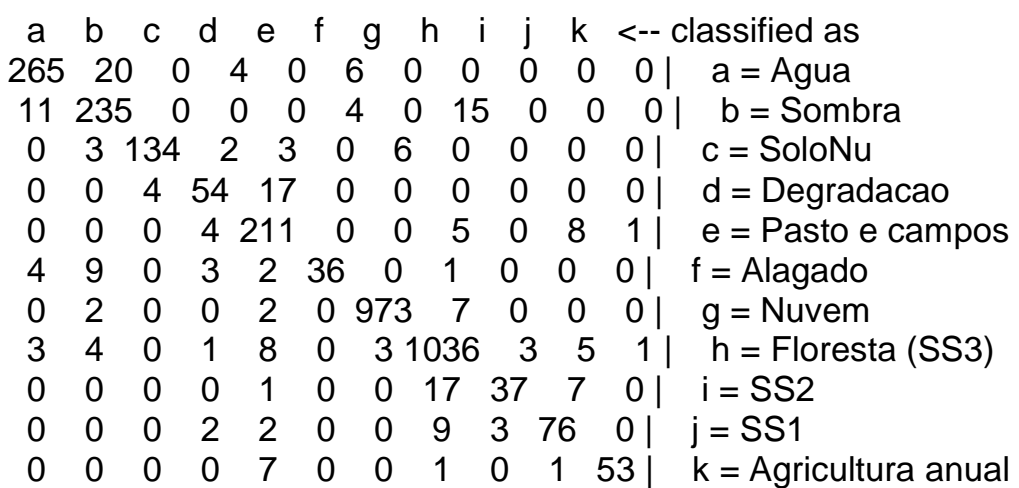




\section{CLASSIFICAÇÃO DE 2008}

Number of Leaf Nodes: 40

Size of the Tree: 79

Time taken to build model: 1.15 seconds

$===$ Evaluation on training set $===$

Time taken to test model on training data: 0.01 seconds

$===$ Summary $===$

$\begin{array}{lcc}\text { Correctly Classified Instances } & 2258 & 93.8097 \% \\ \text { Incorrectly Classified Instances } & 149 & 6.1903 \% \\ \text { Kappa statistic } & 0.924 & \\ \text { Mean absolute error } & 0.0195 & \\ \text { Root mean squared error } & 0.0986 & \\ \text { Relative absolute error } & 13.1166 \% & \\ \text { Root relative squared error } & 36.2262 \% & \\ \text { Total Number of Instances } & 2407 & \end{array}$

$===$ Detailed Accuracy By Class $===$

\begin{tabular}{rlllllllll}
\multicolumn{1}{c}{ TP Rate FP Rate Precision Recall F-Measure } & MCC & \multicolumn{2}{c}{ ROC Area PRC Area Class } \\
0.943 & 0.003 & 0.963 & 0.943 & 0.953 & 0.949 & 0.990 & 0.947 & Solo exposto \\
0.933 & 0.013 & 0.919 & 0.933 & 0.926 & 0.915 & 0.993 & 0.955 & Agua \\
0.935 & 0.008 & 0.905 & 0.935 & 0.920 & 0.913 & 0.994 & 0.914 & Pasto e campos \\
0.977 & 0.012 & 0.971 & 0.977 & 0.974 & 0.963 & 0.994 & 0.976 & Nuvem \\
0.958 & 0.012 & 0.955 & 0.958 & 0.957 & 0.945 & 0.990 & 0.965 & Floresta (SS3) \\
0.447 & 0.001 & 0.895 & 0.447 & 0.596 & 0.629 & 0.973 & 0.535 & Alagado \\
0.523 & 0.001 & 0.920 & 0.523 & 0.667 & 0.690 & 0.972 & 0.630 & SS2 \\
0.944 & 0.014 & 0.912 & 0.944 & 0.928 & 0.917 & 0.993 & 0.935 & Sombra \\
1.000 & 0.000 & 1.000 & 1.000 & 1.000 & 1.000 & 1.000 & 1.000 & Agricultura anual \\
0.917 & 0.007 & 0.733 & 0.917 & 0.815 & 0.816 & 0.996 & 0.719 & SS1 \\
& 0.867 & 0.002 & 0.765 & 0.867 & 0.813 & 0.813 & 0.992 & 0.774 & Degradacao \\
W. Avg. & 0.938 & 0.011 & 0.939 & 0.938 & 0.936 & 0.927 & 0.992 & 0.939 &
\end{tabular}

$===$ Confusion Matrix $===$

$a$ b c d e f g h i j $k$ <-- classified as

\begin{tabular}{lllllllllll|l}
181 & 0 & 2 & 9 & 0 & 0 & 0 & 0 & 0 & 0 & 0 & $a=$ Solo exposto
\end{tabular}

\begin{tabular}{llllllllll|l}
1308 & 0 & 2 & 0 & 0 & 0 & 18 & 0 & 0 & 1 & $b=$ Agua
\end{tabular}

\begin{tabular}{llllllllll|l}
0 & 5 & 172 & 2 & 0 & 2 & 0 & 0 & 0 & 2 & 1
\end{tabular}$\quad \mathrm{c}=$ Pasto e campos

\begin{tabular}{lllllllllll|l}
5 & 1 & 2707 & 7 & 0 & 0 & 2 & 0 & 0 & 0 & $\mathrm{~d}=$ Nuvem
\end{tabular}

\begin{tabular}{lllllllllll|l}
0 & 2 & 4 & 4 & 485 & 0 & 1 & 5 & 0 & 3 & $2 \mid$ & $e=$ Floresta (SS3)
\end{tabular}

\begin{tabular}{lllllllllll|l}
1 & 8 & 6 & 0 & 2 & 17 & 0 & 4 & 0 & 0 & 0 & $\mathrm{f}=$ Alagado
\end{tabular}

\begin{tabular}{lllllllllll|l}
0 & 0 & 2 & 0 & 8 & 0 & 23 & 0 & 0 & 11 & 0 & $g=$ SS2
\end{tabular}

\begin{tabular}{lllllllllll|l}
0 & 10 & 0 & 4 & 4 & 0 & 0 & 302 & 0 & 0 & 0 & $\mathrm{~h}=$ Sombra
\end{tabular}

\begin{tabular}{lllllllllll|l}
0 & 0 & 0 & 0 & 0 & 0 & 0 & 0 & 6 & 0 & 0 & $\mathrm{i}=$ Agricultura anual
\end{tabular}

\begin{tabular}{lllllllllll|l}
0 & 0 & 2 & 0 & 1 & 0 & 1 & 0 & 0 & 44 & 0 & $\mathrm{j}=\mathrm{SS} 1$
\end{tabular}

\begin{tabular}{lllllllllll|l}
0 & 1 & 0 & 0 & 1 & 0 & 0 & 0 & 0 & 0 & 13 & $\mathrm{k}=$ Degradacao
\end{tabular} 


\section{CLASSIFICAÇÃO DE 2009}

Number of Leaf Nodes: 27

Size of the Tree: 53

Time taken to build model: 0.8 seconds

$===$ Evaluation on training set $===$

Time taken to test model on training data: 0.01 seconds

$===$ Summary $===$

$\begin{array}{lcc}\text { Correctly Classified Instances } & 1637 & 94.0805 \% \\ \text { Incorrectly Classified Instances } & 103 & 5.9195 \% \\ \text { Kappa statistic } & 0.928 & \\ \text { Mean absolute error } & 0.0189 & \\ \text { Root mean squared error } & 0.0972 & \\ \text { Relative absolute error } & 12.5998 \% & \\ \text { Root relative squared error } & 35.5076 \% & \\ \text { Total Number of Instances } & 1740 & \end{array}$

$===$ Detailed Accuracy By Class $===$

\begin{tabular}{clllllllll}
\multicolumn{1}{l}{ TP Rate FP Rate Precision Recall } & F-Measure & MCC & \multicolumn{2}{c}{ ROC Area PRC Area Class } \\
0.970 & 0.003 & 0.970 & 0.970 & 0.970 & 0.967 & 0.997 & 0.957 & Solo exposto \\
0.968 & 0.021 & 0.933 & 0.968 & 0.950 & 0.935 & 0.992 & 0.966 & Agua \\
0.762 & 0.002 & 0.941 & 0.762 & 0.842 & 0.842 & 0.984 & 0.826 & Sombra \\
0.935 & 0.000 & 1.000 & 0.935 & 0.967 & 0.964 & 0.994 & 0.962 & Nuvem \\
0.947 & 0.022 & 0.875 & 0.947 & 0.910 & 0.895 & 0.987 & 0.897 & Pasto e campos \\
0.982 & 0.007 & 0.982 & 0.982 & 0.982 & 0.974 & 0.997 & 0.986 & Floresta (SS3) \\
0.364 & 0.001 & 0.667 & 0.364 & 0.471 & 0.490 & 0.986 & 0.357 & Alagado \\
0.859 & 0.004 & 0.887 & 0.859 & 0.873 & 0.868 & 0.990 & 0.834 & SS2 \\
0.879 & 0.005 & 0.909 & 0.879 & 0.894 & 0.888 & 0.992 & 0.864 & Agricultura anual \\
0.848 & 0.005 & 0.830 & 0.848 & 0.839 & 0.834 & 0.994 & 0.788 & SS1 \\
W. Avg. & 0.500 & 0.000 & 1.000 & 0.500 & 0.667 & 0.706 & 0.951 & 0.574 & Degradacao \\
& 0.941 & 0.011 & 0.941 & 0.941 & 0.940 & 0.931 & 0.993 & 0.935 &
\end{tabular}

$===$ Confusion Matrix $===$

a b c d e f $g$ h i j $k$ <-- classified as

\begin{tabular}{lllllllllll|l}
160 & 0 & 0 & 0 & 5 & 0 & 0 & 0 & 0 & 0 & 0 & $a=$ Solo exposto
\end{tabular}

\begin{tabular}{lllllllllll|l}
0 & 392 & 3 & 0 & 7 & 1 & 1 & 1 & 0 & 0 & 0 & $\mathrm{~b}=$ Agua
\end{tabular}

\begin{tabular}{lllllllllll|l}
0 & 15 & 48 & 0 & 0 & 0 & 0 & 0 & 0 & 0 & 0 & $\mathrm{c}=$ Sombra
\end{tabular}

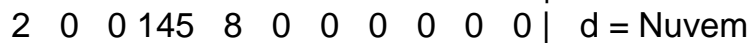

\begin{tabular}{lllllllllll|l}
3 & 2 & 0 & 0 & 232 & 0 & 0 & 0 & 7 & 1 & 0 & $\mathrm{e}=$ Pasto e campos
\end{tabular}

\begin{tabular}{lllllllllll|l}
0 & 2 & 0 & 0 & 1 & 478 & 0 & 3 & 0 & 3 & 0 & $f=$ Floresta (SS3)
\end{tabular}

\begin{tabular}{lllllllllll|l}
0 & 7 & 0 & 0 & 0 & 0 & 4 & 0 & 0 & 0 & 0 & $\mathrm{~g}=$ Alagado
\end{tabular}

\begin{tabular}{lllllllllll|l}
0 & 1 & 0 & 0 & 1 & 6 & 0 & 55 & 0 & 1 & 0 & $\mathrm{~h}=\mathrm{SS} 2$
\end{tabular}

\begin{tabular}{lllllllllll|l}
0 & 0 & 0 & 0 & 8 & 0 & 0 & 0 & 80 & 3 & 0 & $\mathrm{i}=$ Agricultura anual
\end{tabular}

\begin{tabular}{lllllllllll|l}
0 & 0 & 0 & 0 & 3 & 0 & 0 & 3 & 1 & 39 & 0 & $\mathrm{j}=\mathrm{SS} 1$
\end{tabular}

\begin{tabular}{lllllllllll|l}
0 & 1 & 0 & 0 & 0 & 2 & 1 & 0 & 0 & 0 & 4 & $\mathrm{k}=$ Degradacao
\end{tabular} 


\section{CLASSIFICAÇÃO DE 2010}

Number of Leaf Nodes: 46

Size of the Tree: 91

Time taken to build model: 1.48 seconds

$===$ Evaluation on training set $===$

Time taken to test model on training data: 0.01 seconds

$===$ Summary $===$

$\begin{array}{lcc}\text { Correctly Classified Instances } & 2503 & 93.0829 \% \\ \text { Incorrectly Classified Instances } & 186 & 6.9171 \% \\ \text { Kappa statistic } & 0.9155 & \\ \text { Mean absolute error } & 0.0214 & \\ \text { Root mean squared error } & 0.1035 & \\ \text { Relative absolute error } & 14.354 \% & \\ \text { Root relative squared error } & 37.895 \% & \\ \text { Total Number of Instances } & 2689 & \end{array}$

$===$ Detailed Accuracy By Class $===$

\begin{tabular}{ccccccccll}
\multicolumn{1}{l}{ TP Rate FP Rate Precision Recall F-Measure } & MCC & \multicolumn{2}{l}{ ROC Area PRC Area Class } \\
0.926 & 0.012 & 0.918 & 0.926 & 0.922 & 0.910 & 0.995 & 0.963 & Agua \\
0.982 & 0.001 & 0.991 & 0.982 & 0.987 & 0.985 & 0.999 & 0.992 & Solo exposto \\
0.805 & 0.005 & 0.910 & 0.805 & 0.854 & 0.847 & 0.990 & 0.874 & Pasto e campos \\
0.700 & 0.007 & 0.767 & 0.700 & 0.732 & 0.725 & 0.987 & 0.700 & Alagado \\
0.975 & 0.024 & 0.958 & 0.975 & 0.966 & 0.947 & 0.992 & 0.974 & Floresta (SS3) \\
0.878 & 0.004 & 0.929 & 0.878 & 0.903 & 0.897 & 0.991 & 0.921 & Sombra \\
0.872 & 0.015 & 0.769 & 0.872 & 0.817 & 0.808 & 0.986 & 0.741 & SS1 \\
0.786 & 0.011 & 0.786 & 0.786 & 0.786 & 0.775 & 0.962 & 0.700 & SS2 \\
0.889 & 0.000 & 0.960 & 0.889 & 0.923 & 0.923 & 0.993 & 0.888 & Degradacao \\
0.937 & 0.002 & 0.952 & 0.937 & 0.944 & 0.942 & 0.997 & 0.927 & Agricultura anual \\
1.000 & 0.001 & 0.994 & 1.000 & 0.997 & 0.997 & 1.000 & 0.997 & Nuvem \\
W. Avg. & 0.931 & 0.012 & 0.931 & 0.931 & 0.931 & 0.920 & 0.992 & 0.931 &
\end{tabular}

$===$ Confusion Matrix $===$

$a$ b c d e f g h i j $k$ <-- classified as

\begin{tabular}{lllllllllll|l}
324 & 0 & 1 & 13 & 7 & 5 & 0 & 0 & 0 & 0 & 0 & $a=$ Agua
\end{tabular}

\begin{tabular}{llllllllll|l}
0221 & 3 & 0 & 0 & 0 & 0 & 0 & 0 & 0 & $1 \mid$ & $b=$ Solo exposto
\end{tabular}

\begin{tabular}{lllllllllll|l}
0 & 2 & 132 & 0 & 6 & 0 & 19 & 3 & 0 & 2 & 0 & $\mathrm{c}=$ = Pasto e campos
\end{tabular}

\begin{tabular}{lllllllllll|l}
17 & 0 & 0 & 56 & 3 & 4 & 0 & 0 & 0 & 0 & 0 & $\mathrm{~d}=$ Alagado
\end{tabular}

\begin{tabular}{llllllllll|l}
1 & 0 & 4 & 1924 & 2 & 2 & 14 & 0 & 0 & 0 & $e=$ Floresta (SS3)
\end{tabular}

\begin{tabular}{lllllllllll|l}
11 & 0 & 1 & 3 & 3 & 144 & 0 & 0 & 1 & 0 & 1 & $f=$ Sombra
\end{tabular}

\begin{tabular}{lllllllllll|l}
0 & 0 & 2 & 0 & 2 & 0 & 123 & 10 & 0 & 4 & 0 & $g=S S 1$
\end{tabular}

\begin{tabular}{lllllllllll|l}
0 & 0 & 0 & 0 & 18 & 0 & 9 & 99 & 0 & 0 & 0 & $\mathrm{~h}=\mathrm{SS} 2$
\end{tabular}

$\begin{array}{llllllllllll}0 & 0 & 1 & 0 & 2 & 0 & 0 & 0 & 24 & 0 & 0 & \mathbf{i}=\text { Degradacao }\end{array}$

$\begin{array}{lllllllllllll}0 & 0 & 1 & 0 & 0 & 0 & 7 & 0 & 0 & 119 & 0 & \mathrm{j}=\text { Agricultura anual }\end{array}$

$\begin{array}{lllllllllllll}0 & 0 & 0 & 0 & 0 & 0 & 0 & 0 & 0 & 0 & 337 & \mathrm{k}=\text { Nuvem }\end{array}$ 


\section{CLASSIFICAÇÃO DE 2012}

Number of Leaf Nodes: 30

Size of the Tree: 59

Time taken to build model: 2.92 seconds

$===$ Evaluation on training set $===$

Time taken to test model on training data: 0.01 seconds

$===$ Summary $===$

$\begin{array}{lcc}\text { Correctly Classified Instances } & 4986 & 88.2166 \% \\ \text { Incorrectly Classified Instances } & 666 & 11.7834 \% \\ \text { Kappa statistic } & 0.8431 & \\ \text { Mean absolute error } & 0.0424 & \\ \text { Root mean squared error } & 0.1456 & \\ \text { Relative absolute error } & 25.0424 \% & \\ \text { Root relative squared error } & 50.049 \% & \\ \text { Total Number of Instances } & 5652 & \end{array}$

$===$ Detailed Accuracy By Class $===$

\begin{tabular}{|c|c|c|c|c|c|c|c|c|}
\hline TP Rat & FP & & & & & M & $\mathrm{ROC}$ & \\
\hline 0.830 & 0.033 & 0.695 & 0.830 & 0.757 & 0.736 & 0.970 & 0.680 & Pasto e campos \\
\hline 0.899 & 0.011 & 0.941 & 0.899 & 0.919 & 0.905 & 0.993 & 0.946 & Solo exposto \\
\hline 0.455 & 0.005 & 0.757 & 0.455 & 0.569 & 0.576 & 0.916 & 0.515 & Alagado \\
\hline .958 & 0.013 & 0.908 & 0.958 & 0.932 & 0.924 & 0.995 & 0.949 & Agua \\
\hline 0.976 & 0.065 & 0.918 & 0.976 & 0.946 & 0.906 & 0.980 & 0.952 & Floresta (SS3) \\
\hline 0.507 & 0.008 & 0.629 & 0.507 & 0.562 & 0.555 & 0.926 & 0.439 & Degradacao \\
\hline 0.871 & 0.004 & 0.946 & 0.871 & 0.907 & 0.901 & 0.988 & & Agrcultura Anual \\
\hline .854 & 0.007 & 0.844 & 0.854 & 0.849 & 0.842 & 0.984 & 0.825 & SS1 \\
\hline 0.310 & 0.007 & 0.625 & 0.310 & 0.414 & 0.426 & 0.925 & 0.407 & SS2 \\
\hline .88 & 0.035 & 0.877 & 0.882 & 0.875 & 0.852 & 0.978 & 0.870 & \\
\hline
\end{tabular}

$===$ Confusion Matrix $===$

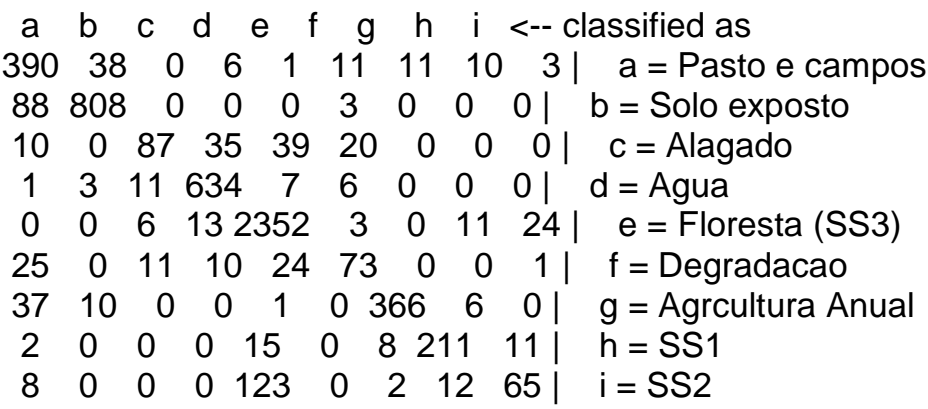




\section{CLASSIFICAÇÃO DE 2013}

Number of Leaf Nodes: 27

Size of the Tree: 53

Time taken to build model: 0.8 seconds

$===$ Evaluation on training set $===$

Time taken to test model on training data: 0.01 seconds

$===$ Summary $===$

$\begin{array}{lcc}\text { Correctly Classified Instances } & 1637 & 94.0805 \% \\ \text { Incorrectly Classified Instances } & 103 & 5.9195 \% \\ \text { Kappa statistic } & 0.928 & \\ \text { Mean absolute error } & 0.0189 & \\ \text { Root mean squared error } & 0.0972 & \\ \text { Relative absolute error } & 12.5998 \% & \\ \text { Root relative squared error } & 35.5076 \% & \\ \text { Total Number of Instances } & 1740 & \end{array}$

$===$ Detailed Accuracy By Class $===$

\begin{tabular}{clllllllll}
\multicolumn{1}{l}{ TP Rate FP Rate Precision Recall F-Measure } & MCC & \multicolumn{2}{c}{ ROC Area PRC Area Class } \\
0.970 & 0.003 & 0.970 & 0.970 & 0.970 & 0.967 & 0.997 & 0.957 & Solo exposto \\
0.968 & 0.021 & 0.933 & 0.968 & 0.950 & 0.935 & 0.992 & 0.966 & Agua \\
0.762 & 0.002 & 0.941 & 0.762 & 0.842 & 0.842 & 0.984 & 0.826 & Sombra \\
0.935 & 0.000 & 1.000 & 0.935 & 0.967 & 0.964 & 0.994 & 0.962 & Nuvem \\
0.947 & 0.022 & 0.875 & 0.947 & 0.910 & 0.895 & 0.987 & 0.897 & Pasto e campos \\
0.982 & 0.007 & 0.982 & 0.982 & 0.982 & 0.974 & 0.997 & 0.986 & Floresta (SS3) \\
0.364 & 0.001 & 0.667 & 0.364 & 0.471 & 0.490 & 0.986 & 0.357 & Alagado \\
0.859 & 0.004 & 0.887 & 0.859 & 0.873 & 0.868 & 0.990 & 0.834 & SS2 \\
0.879 & 0.005 & 0.909 & 0.879 & 0.894 & 0.888 & 0.992 & 0.864 & Agricultura anual \\
0.848 & 0.005 & 0.830 & 0.848 & 0.839 & 0.834 & 0.994 & 0.788 & SS1 \\
& 0.500 & 0.000 & 1.000 & 0.500 & 0.667 & 0.706 & 0.951 & 0.574 & Degradacao \\
W. Avg. & 0.941 & 0.011 & 0.941 & 0.941 & 0.940 & 0.931 & 0.993 & 0.935 &
\end{tabular}

$===$ Confusion Matrix $===$

a b c d e f $g$ h i j $k$ <-- classified as

\begin{tabular}{lllllllllll|l}
160 & 0 & 0 & 0 & 5 & 0 & 0 & 0 & 0 & 0 & 0 & $a=$ Solo exposto
\end{tabular}

\begin{tabular}{lllllllllll|l}
0 & 392 & 3 & 0 & 7 & 1 & 1 & 1 & 0 & 0 & 0 & $\mathrm{~b}=$ Agua
\end{tabular}

\begin{tabular}{lllllllllll|l}
0 & 15 & 48 & 0 & 0 & 0 & 0 & 0 & 0 & 0 & 0 & $\mathrm{c}=$ Sombra
\end{tabular}

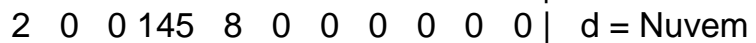

\begin{tabular}{lllllllllll|l}
3 & 2 & 0 & 0 & 232 & 0 & 0 & 0 & 7 & 1 & 0 & $\mathrm{e}=$ Pasto e campos
\end{tabular}

\begin{tabular}{lllllllllll|l}
0 & 2 & 0 & 0 & 1 & 478 & 0 & 3 & 0 & 3 & 0 & $f=$ Floresta (SS3)
\end{tabular}

\begin{tabular}{lllllllllll|l}
0 & 7 & 0 & 0 & 0 & 0 & 4 & 0 & 0 & 0 & 0 & $\mathrm{~g}=$ Alagado
\end{tabular}

\begin{tabular}{lllllllllll|l}
0 & 1 & 0 & 0 & 1 & 6 & 0 & 55 & 0 & 1 & 0 & $\mathrm{~h}=\mathrm{SS} 2$
\end{tabular}

\begin{tabular}{lllllllllll|l}
0 & 0 & 0 & 0 & 8 & 0 & 0 & 0 & 80 & 3 & 0 & $\mathrm{i}=$ Agricultura anual
\end{tabular}

\begin{tabular}{lllllllllll|l}
0 & 0 & 0 & 0 & 3 & 0 & 0 & 3 & 1 & 39 & 0 & $\mathrm{j}=\mathrm{SS} 1$
\end{tabular}

\begin{tabular}{lllllllllll|l}
0 & 1 & 0 & 0 & 0 & 2 & 1 & 0 & 0 & 0 & 4 & $\mathrm{k}=$ Degradacao
\end{tabular} 


\section{CLASSIFICAÇÃO DE 2014}

Number of Leaf Nodes: 31

Size of the Tree: 61

Time taken to build model: 1.11 seconds

$===$ Evaluation on training set $===$

Time taken to test model on training data: 0.01 seconds

$===$ Summary $===$

$\begin{array}{lcc}\text { Correctly Classified Instances } & 2090 & 89.9699 \% \\ \text { Incorrectly Classified Instances } & 233 & 10.0301 \% \\ \text { Kappa statistic } & 0.8789 & \\ \text { Mean absolute error } & 0.0326 & \\ \text { Root mean squared error } & 0.1277 & \\ \text { Relative absolute error } & 19.5485 \% & \\ \text { Root relative squared error } & 44.2211 \% & \\ \text { Total Number of Instances } & 2323 & \end{array}$

$===$ Detailed Accuracy By Class $===$

TP Rate FP Rate Precision Recall F-Measure MCC ROC Area PRC Area Class

$\begin{array}{lllllllll}0.915 & 0.007 & 0.964 & 0.915 & 0.939 & 0.927 & 0.991 & 0.951 & \text { Agua }\end{array}$

$\begin{array}{lllllllll}0.846 & 0.003 & 0.880 & 0.846 & 0.863 & 0.860 & 0.986 & 0.805 & \text { Alagado }\end{array}$

$\begin{array}{lllllllll}0.965 & 0.053 & 0.864 & 0.965 & 0.912 & 0.881 & 0.987 & 0.944 & \text { Floresta (SS3) }\end{array}$

$\begin{array}{lllllllll}0.729 & 0.013 & 0.861 & 0.729 & 0.790 & 0.772 & 0.960 & 0.798 & \text { Sombra }\end{array}$

$\begin{array}{lllllllll}0.929 & 0.024 & 0.824 & 0.929 & 0.873 & 0.859 & 0.987 & 0.841 & \text { Pasto e campos }\end{array}$

$\begin{array}{lllllllll}0.325 & 0.000 & 0.929 & 0.325 & 0.481 & 0.546 & 0.963 & 0.484 & \text { SS1 }\end{array}$

$\begin{array}{lllllllll}0.896 & 0.013 & 0.905 & 0.896 & 0.901 & 0.887 & 0.991 & 0.931 & \text { Solo exposto }\end{array}$

$\begin{array}{lllllllll}0.980 & 0.005 & 0.975 & 0.980 & 0.977 & 0.972 & 0.999 & 0.987 & \text { Nuvem }\end{array}$

$\begin{array}{lllllllll}0.000 & 0.000 & 0.000 & 0.000 & 0.000 & 0.000 & 0.920 & 0.017 & \text { Degradacao }\end{array}$

$\begin{array}{lllllllll}0.580 & 0.003 & 0.829 & 0.580 & 0.682 & 0.688 & 0.967 & 0.570 & \text { SS2 }\end{array}$

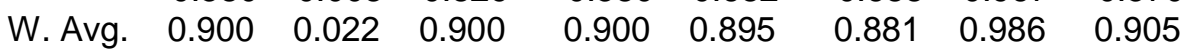

$===$ Confusion Matrix $===$

a b c d e f g h i j <-- classified as

$\begin{array}{llllllllllll}379 & 4 & 4 & 18 & 7 & 0 & 2 & 0 & 0 & 0 & a=\text { Agua }\end{array}$

\begin{tabular}{llllllllll|l}
5 & 44 & 1 & 0 & 0 & 0 & 2 & 0 & 0 & 0 & $\mathrm{~b}=$ Alagado
\end{tabular}

$\begin{array}{llllllllllll}0 & 0 & 582 & 4 & 7 & 1 & 3 & 4 & 0 & 2 & \mathrm{c}=\text { Floresta (SS3) }\end{array}$

\begin{tabular}{llllllllll|l}
8 & 2 & 32 & 167 & 9 & 0 & 5 & 6 & 0 & 0 & $\mathrm{~d}=$ Sombra
\end{tabular}

\begin{tabular}{lllllllll|l}
0 & 0 & 5 & 1234 & 0 & 12 & 0 & 0 & 0 & $\mathrm{e}=$ Pasto e campos
\end{tabular}

\begin{tabular}{llllllllll|l}
0 & 0 & 23 & 0 & 0 & 13 & 0 & 0 & 0 & 4 & $\mathrm{f}=\mathrm{SS} 1$
\end{tabular}

\begin{tabular}{llllllllll|l}
1 & 0 & 0 & 2 & 27 & 0 & 258 & 0 & 0 & 0 & $\mathrm{~g}=$ Solo exposto
\end{tabular}

\begin{tabular}{llllllllll|l}
0 & 0 & 4 & 2 & 0 & 0 & 2384 & 0 & 0 & $\mathrm{~h}=$ Nuvem
\end{tabular}

\begin{tabular}{llllllllll|l}
0 & 0 & 2 & 0 & 0 & 0 & 1 & 0 & 0 & 0 & $\mathrm{i}=$ Degradacao
\end{tabular}

\begin{tabular}{llllllllll|l}
0 & 0 & 21 & 0 & 0 & 0 & 0 & 0 & 0 & 29 & $j=S S 2$
\end{tabular} 


\section{CLASSIFICAÇÃO DE 2015}

Number of Leaf Nodes: 37

Size of the Tree: 73

Time taken to build model: 0.94 seconds

$===$ Evaluation on training set $===$

Time taken to test model on training data: 0.01 seconds

$===$ Summary $===$

$\begin{array}{lcc}\text { Correctly Classified Instances } & 1947 & 92.7585 \% \\ \text { Incorrectly Classified Instances } & 152 & 7.2415 \% \\ \text { Kappa statistic } & 0.8996 & \\ \text { Mean absolute error } & 0.0231 & \\ \text { Root mean squared error } & 0.1074 & \\ \text { Relative absolute error } & 17.4019 \% & \\ \text { Root relative squared error } & 41.7424 \% & \\ \text { Total Number of Instances } & 2099 & \end{array}$

$===$ Detailed Accuracy By Class $===$

\begin{tabular}{ccccccccll}
\multicolumn{1}{l}{ TP Rate FP Rate Precision Recall } & F-Measure & MCC & \multicolumn{2}{c}{ ROC Area PRC Area Class } \\
0.909 & 0.017 & 0.876 & 0.909 & 0.892 & 0.878 & 0.989 & 0.879 & Pasto e Campos \\
0.947 & 0.000 & 1.000 & 0.947 & 0.973 & 0.973 & 0.998 & 0.961 & Solo exposto \\
0.924 & 0.006 & 0.942 & 0.924 & 0.933 & 0.925 & 0.997 & 0.961 & Agua \\
0.937 & 0.008 & 0.813 & 0.937 & 0.871 & 0.868 & 0.994 & 0.816 & Degradacao \\
0.792 & 0.007 & 0.813 & 0.792 & 0.803 & 0.795 & 0.983 & 0.774 & Alagado \\
1.000 & 0.001 & 0.966 & 1.000 & 0.983 & 0.982 & 0.999 & 0.966 & Nuvem \\
0.911 & 0.009 & 0.844 & 0.911 & 0.876 & 0.870 & 0.981 & 0.849 & SS1 \\
0.993 & 0.035 & 0.964 & 0.993 & 0.978 & 0.958 & 0.983 & 0.966 & Floresta (SS3) \\
0.808 & 0.001 & 0.933 & 0.808 & 0.866 & 0.865 & 0.996 & 0.890 & Sombra \\
0.787 & 0.008 & 0.850 & 0.787 & 0.817 & 0.808 & 0.987 & 0.799 & Agricultura anual \\
& 0.397 & 0.001 & 0.931 & 0.397 & 0.557 & 0.601 & 0.874 & 0.494 & SS2 \\
W. Avg. & 0.928 & 0.021 & 0.928 & 0.928 & 0.924 & 0.912 & 0.984 & 0.912 &
\end{tabular}

$===$ Confusion Matrix $===$

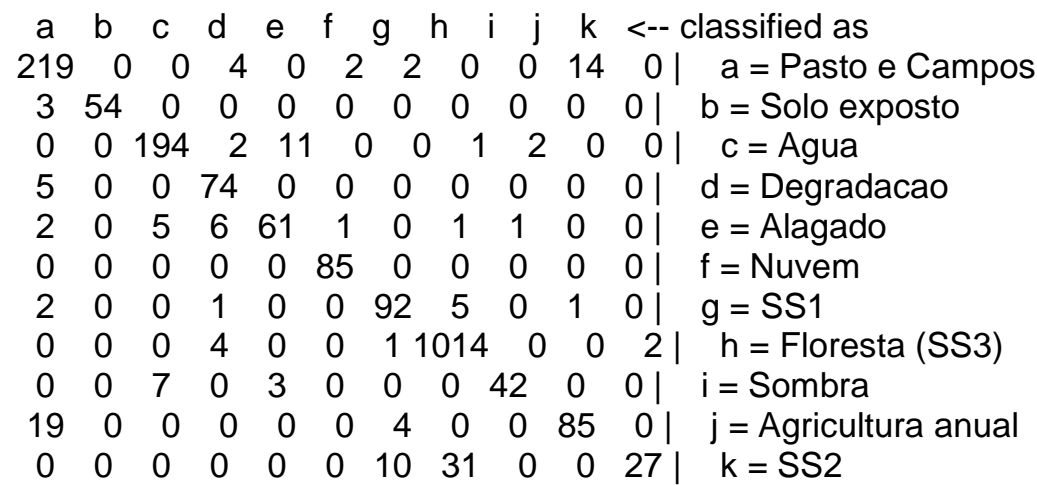




\section{CLASSIFICAÇÃO DE 2016}

Number of Leaf Nodes: 24

Size of the Tree: 47

Time taken to build model: 0.74 seconds

$===$ Evaluation on training set $===$

Time taken to test model on training data: 0 seconds

$===$ Summary $===$

$\begin{array}{lcc}\text { Correctly Classified Instances } & 1582 & 92.7859 \% \\ \text { Incorrectly Classified Instances } & 123 & 7.2141 \% \\ \text { Kappa statistic } & 0.9147 & \\ \text { Mean absolute error } & 0.0227 & \\ \text { Root mean squared error } & 0.1066 & \\ \text { Relative absolute error } & 14.7763 \% & \\ \text { Root relative squared error } & 38.449 \% & \\ \text { Total Number of Instances } & 1705 & \end{array}$

$===$ Detailed Accuracy By Class ===

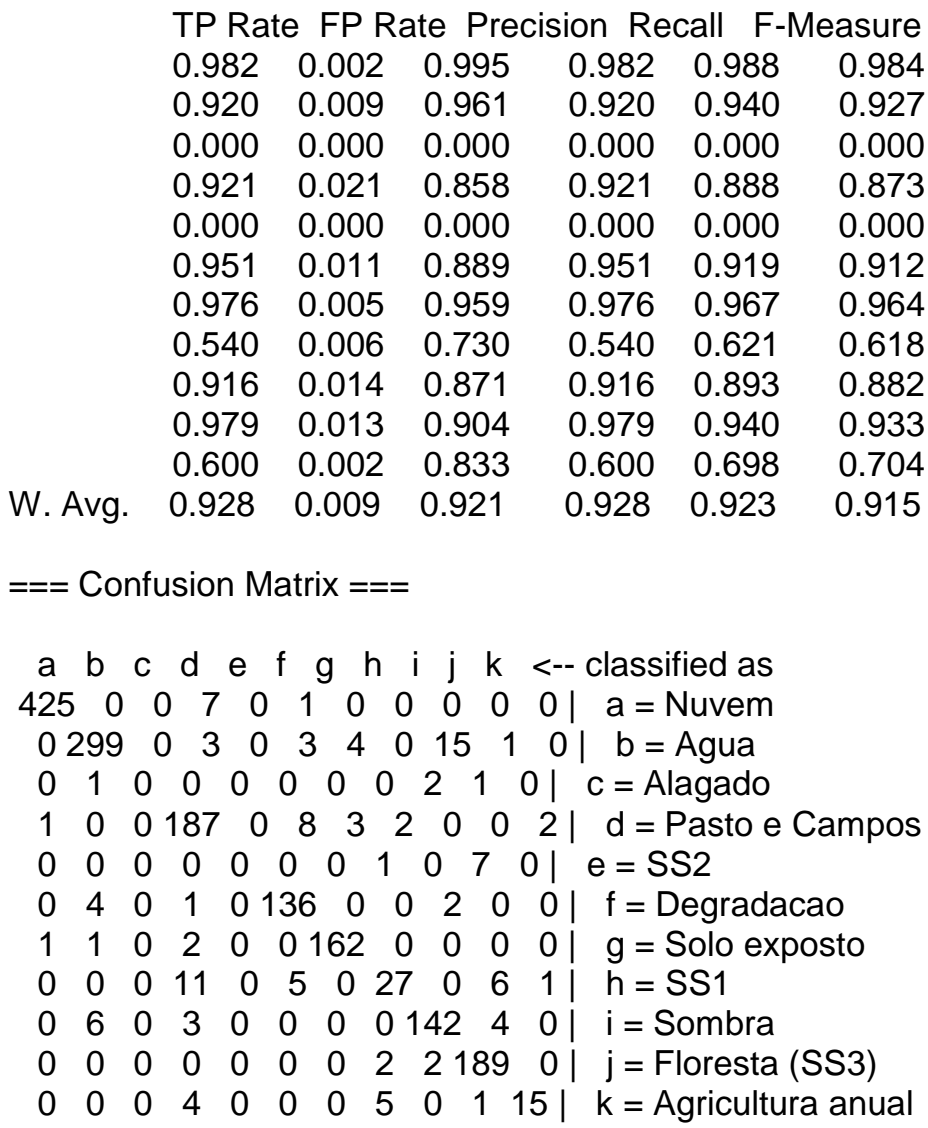

